Florida International University FIU Digital Commons

\title{
Novel nucleoside analogues with bases modified with ( $\beta$-halo)vinyl sulfone or $\beta$-keto sulfone as probes to study RNA/DNA-Proteins interactions
}

Sk Md Sazzad Hossain Suzol

shoss015@fiu.edu

DOI: $10.25148 /$ etd.FIDC001985

Follow this and additional works at: https://digitalcommons.fiu.edu/etd

Part of the Organic Chemistry Commons

\section{Recommended Citation}

Suzol, Sk Md Sazzad Hossain, "Novel nucleoside analogues with bases modified with ( $\beta$-halo)vinyl sulfone or $\beta$-keto sulfone as probes to study RNA/DNA-Proteins interactions" (2017). FIU Electronic Theses and Dissertations. 3372.

https://digitalcommons.fiu.edu/etd/3372 


\title{
FLORIDA INTERNATIONAL UNIVERSITY \\ Miami, Florida
}

\section{NOVEL NUCLEOSIDE ANALOGUES WITH BASES MODIFIED WITH ( $\beta$ - HALO)VINYL SULFONE OR $\beta$-KETO SULFONE AS PROBES TO STUDY RNA/DNA-PROTEINS INTERACTIONS}

\author{
A dissertation submitted in partial fulfillment of \\ the requirements for the degree of \\ DOCTOR OF PHILOSOPHY \\ in \\ CHEMISTRY \\ by
}

Sk Md Sazzad Hossain Suzol 
To: Dean Michael R. Heithaus

College of Arts, Sciences, and Education

This dissertation, written by Sk Md Sazzad Hossain Suzol, and entitled Novel Nucleoside Analogues with Bases Modified with ( $\beta$-Halo)vinyl Sulfone or $\beta$-Keto Sulfone as Probes to Study RNA/DNA-Proteins Interactions, having been approved in respect to style and intellectual content, is referred to you for judgment.

We have read this dissertation and recommend that it be approved.

$\begin{array}{r}\hline \text { Kevin O'Shea } \\ \hline \text { Joong Ho Moon } \\ \hline \text { Anthony De Caprio } \\ \hline \text { Deodutta Roy } \\ \hline \text { Stanislaw F. Wnuk, Major Professor }\end{array}$

Date of Defense: June 28, 2017

The dissertation of Sk Md Sazzad Hossain Suzol is approved.

Dean Michael R. Heithaus

College of Arts, Sciences and Education

Andrés G. Gil

Vice President for Research and Economic Development and Dean of the University Graduate School

Florida International University, 2017 


\section{DEDICATION}

I dedicate this work to my parents and brother who are always inspiring to me. Without their affection and support, the completion of this work would have been impossible. 


\section{ACKNOWLEDGMENTS}

I want to express my humble acknowledgment to the people who will be remembered for their their guidance, co-operation and encouragement.

First of all I want to thank my honorable adviser Dr. Stanislaw F. Wnuk for his outstanding mentorship, and guidance. As a person he was very friendly, however professional in the research activities. I have learnt a lot from him which will be faciliatory in my professional life. I will always remember my professor for his personal care and enormous affection to me!

I want to thank to all my committee members: Dr. Kevin O'Shea, Dr. Joong Ho Moon, Dr. Anthony DeCaprio, Dr. Deodutta Roy for giving me your valuable time and ample support throughout my graduate life. I will be grateful to all of you.

I want to convey my special gratitude to Dr. Rafael Raptis of FIU for providing data of X-ray analysis, Dr. Yuan Liu from FIU for providing details of DNA incorporation, and Dr. Sandra Liekens of Rega Institute for Medical Research, Belgium; for collaborative studies for exploring antiproliferative properties of my analogues. Without their help it wouldn't be possible to progress in my research so smoothly.

I would like to mention my gratitude to Mr. Yong Liang, my senior labmate who had trained me in the lab and was always with me in the lab to help. I would like to thank to all my family members and relative specifically my brother for their encouragement and unwavering support throughout my whole life.

Finally, I would like to thank all of my lab mates and friends for their co-operation throughout my PhD life. You guys have made my life easier! 


\author{
ABSTRACT OF THE DISSERTATION \\ NOVEL NUCLEOSIDE ANALOGUES WITH BASES MODIFIED WITH $(\beta$ - \\ HALO)VINYL SULFONE OR $\beta$-KETO SULFONE AS PROBES TO STUDY \\ RNA/DNA-PROTEINS INTERACTIONS \\ by
}

Sk Md Sazzad Hossain Suzol

Florida International University, 2017

Miami, Florida

Professor Stanislaw F. Wnuk, Major Professor

The C-5 modified pyrimidine analogues are well-known anticancer and antiviral drugs which underscore further development of novel probes to study their physical, chemical, and biological properties. In my dissertation the syntheses and properties of ( $\beta$-halo)vinyl sulfone and/or ( $\beta$-keto)sulfone analogues of C-5 modified pyrimidine have been discussed. In the first part of the dissertion, the synthesis of 5-( $\beta$-halo)vinyl sulfones either by transition metal-catalyzed or iodine-mediated halosulfonylation reaction of 5-acetylene pyrimidine nucleosides have been explored. The novel ( $\beta$ chloro/bromo/iodo)vinyl sulfones efficiently undergo addition-elimination reaction with different nucleophiles such as thiols, amines, amino acid, peptides to provide ( $\beta$ substituted)vinyl sulfone analogues. The rate of these substitution reactions depends on the nature of halogen atom presents at the $\beta$-position and increases with the order of $\mathrm{I} \geq \mathrm{Br}>\mathrm{Cl}$. ( $\beta$-chloro/bromo/iodo)vinyl sulfones possess exclusively $E$ stereochemistry while their $\beta$-substitued analogues possess either $E$ (for $\beta$-thio analogues) or $Z$ (for $\beta$ amino analogue) stereochemistry. It has been observed that the vinylic proton of ( $\beta$ - 
chloro) or ( $\beta$-amino)sulfone analogue undergoes exchanges with deuterium in polar protic deutorated solvents. The antiproliferative activities of those analogues have been explored and was found that protected 5-(E)-(1-chloro-2-tosylvinyl)-2'-deoxyuridine inhibited the growth of L1210, CEM and HeLa cells in lower micromolar range.

In the second part of the dissertation the syntheses and reactivities of 5-( $\beta$-keto) sulfone of pyrimidine nucleosides were investigated. Thus, 5-( $\beta$-halovinyl)sulfone of uracil and cytosine nucleosides have been efficiently converted into corresponding 5( $\beta$-keto) sulfone analogues by displacement of halogen with ammonia followed by acidcatalyzed hydrolysis of the resulting ( $\beta$-amino)sulfone analogues. A number of electrophiles were trapped at the acidic $\alpha$-carbon of the 5-( $\beta$-keto)sulfones by treatment with electrophiles such as methyl, benzyl, or allyl halide in the presence of base. The 5( $\alpha$-iodo- $\beta$-keto)sulfone analogues of uracil nucleosides have been tested as an alternative substrates to probe the incorporation of nucleophiles at $\alpha$-carbon.

In the third part of the dissertation, the synthesis of 5'-phosphates of 5-( $\beta$-chloro) and 5 -( $\beta$-keto $)$ sulfones of 2 '-deoxyuridine and their polymerase-catalyzed incorporation into DNA were evaluated. Thus, 5'-O-phosphorylated analogues have been efficiently incorporated into the DNA by human DNA repair polymerase (pol $\beta$ ) or bacterial polymerase (pol I). 


\section{TABLE OF CONTENTS}

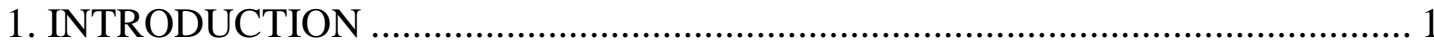

1.1. Importance of nucleosides and nucleotides ....................................................

1.1.1. Nucleoside analogues as anticancer drugs ................................................... 1

1.1.2. Nucleoside analogues as antiviral drugs ......................................................

1.2. 5-Modified pyrimidine nucleosides as reactive probes for bioconjugation .........4

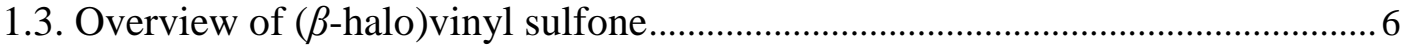

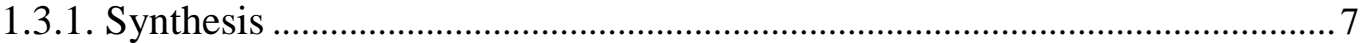

1.3.2. Biological activity .................................................................................... 11

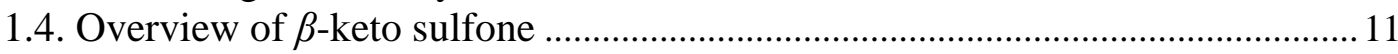

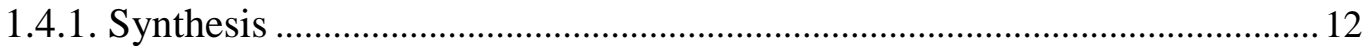

1.4.2. Selected reactions of $\beta$-keto sulfones ......................................................... 15

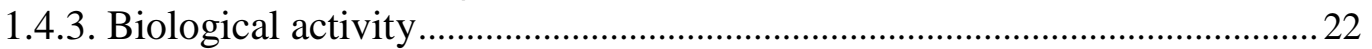

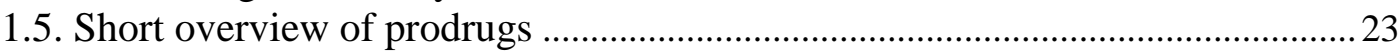

1.5.1. Prodrug of nucleoside analogues ................................................................2

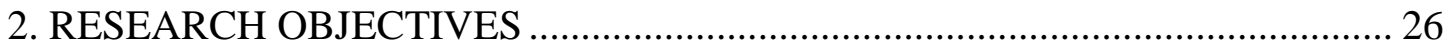

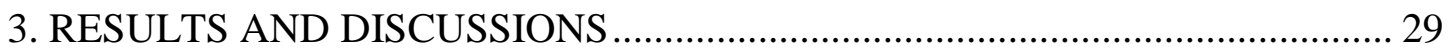

3.1. Chemistry of $(E)$-5-(1-halo-2-tosylvinyl)pyrimidine nucleosides ......................29

3.1.1. Synthesis of (E)-5-(1-chloro/bromo/iodo-2-tosylvinyl)uracil nucleosides 29

3.1.2. Synthesis of (E)-5-(1-chloro/bromo/iodo-2-tosylvinyl)cytosine nucleosides

3.1.3. Addition-elimination reactions of (E)-5-(1-halo-2-tosylvinyl)pyrimidine nucleosides with nucleophiles

3.1.3.1. Kinetics of addition-elimination reaction of (E)-5-(1-halo-2-

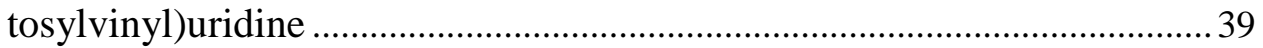

3.1.3.2. Mechanism and stereochemistry ........................................................... 41

3.2. Chemistry of 5-(2-tosylacetyl)uracil and cytosine nucleosides .............................4 46

3.2.1. Synthesis of 5-(2-tosylacetyl)uracil nucleosides .........................................4 49

3.2.1.1. Electrophile trapping at the $\alpha$-carbon of the corresponding $\beta$-keto sulfone.

3.2.1.2. Nucleophile trapping at the $\alpha$-carbon of the $\beta$-keto sulfones................56

3.2.2. Synthesis and reactivity of 5-(2-tosylacetyl)cytosine nucleosides...............56

3.3. Incorporation of ( $\beta$-halo)vinyl sulfone probes at 8-position of 2'deoxyadenosine ............................................................................. 59

3.4. Incorporation of (E)-5-(1-chloro-2-tosylvinyl)-2'-deoxyuridine nucleotide at DNA

3.4.1. Synthesis of 5'-phosphates............................................................................ 61

3.4.2. DNA polymerase catalyzed incorporation into DNA …………………….....64 
3.4.3. Conjugation of phosphorylated chlorovinyl sulfone analogue with Lglutathione.

3.5. Incorporation of 5-(2-tosylacetyl)-2'-deoxyuridine nucleotide at DNA ............68

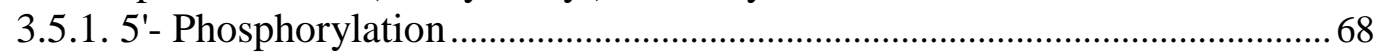

3.5.2. Incorporation into DNA by DNA polymerase ................................................69

3.6. Prodrugs of $\mathrm{C} 5$ modified uracil nucleosides........................................................ 71

3.6.1. Synthesis of prodrug of (E)-5-(1-chloro-2-tosylvinyl)-2'-deoxyuridine ....72

3.6.2. Synthesis of prodrug of 5-(fur-2-yl/5-Heptafur-2-yl)-2'-deoxyuridine .......74

3.6.3. Selected antiviral and anticancer activities.................................................. 76

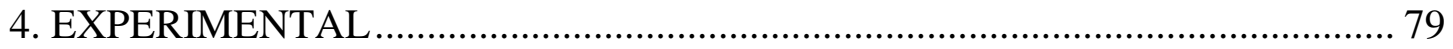

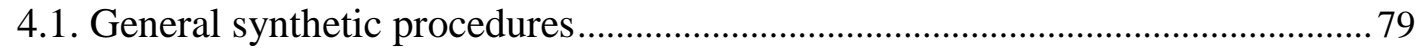

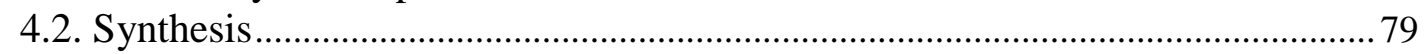

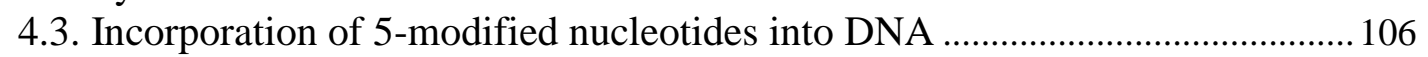

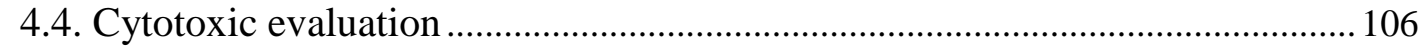

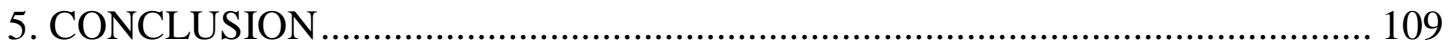

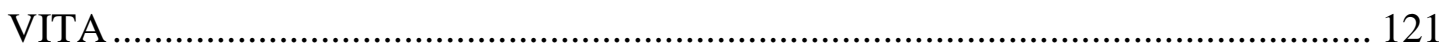




\section{LIST OF TABLES}

TABLE

PAGE

1. FDA approved anticancer purine and pyrimidine nucleoside analogues................. 2

2. Antiviral properties of purine and pyrimidine nucleoside analogues ${ }^{26}$.................. 3

3. Detailed information of nucleotides used during polymerase mediated incorporation

4. Inhibitory effects on the proliferation of murine leukemia cells (L1210), human T-lymphocyte cells (CEM), and human cervix carcinoma cells $(\mathrm{HeLa}){ }^{118}$

5. Anti-herpesvirus activity of the tested compounds in HEP (human embryonic lung) fibroblasts

6. Activity of 5-(5-heptylfur-2-yl)-2'-deoxyuridine against parainfluenza virus 78 


\section{LIST OF FIGURES}

FIGURE

PAGE

1. Synthesis of vinylsulfonamide modified DNA by PEX and its cross-linking with p53 protein $^{36}$ 5

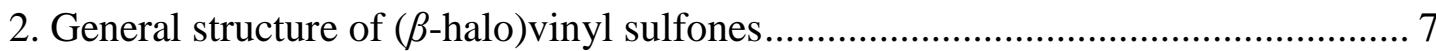

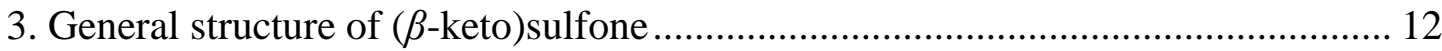

5. 5'-Acylated CP-4126 (A), 4- $N$-acylated prodrug LY2334737 (B) of Gemcitabine and Capecitabine (C) prodrug of 5-fluorouracil ........................... 24

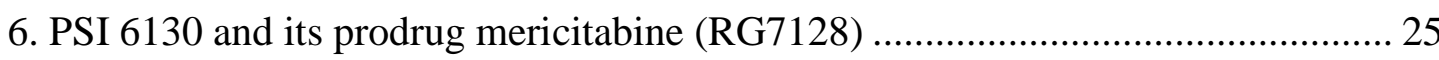

7. General structure of 5-modified pyrimidine nucleoside analogues ...................... 27

8. Intramolecular hydrogen bonding of amino group with oxygen atom of

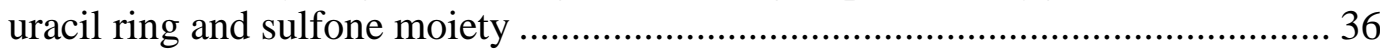

9. Structure of $\beta$-aminovinyl sulfone analogue 33 (left) and its X-ray structure (right). ${ }^{89}$

10. NOESY correlation between the vinylic proton and the H6 proton 37

11. Intramolecular hydrogen bonding in ( $\beta$-aminobutyl)sulfone 33. 38

12. The rate plots for the reactions between 10 (chloro), 11 (bromo), and 12 (iodo) with n-propanethiol in the presence of TEA. The second order rate constant was calculating by plotting $1 /[\beta$-halo vinyl sulfone] as a function of time

13. Ball-and-stick representation of 5-(1-chloro-2-tosylvinyl)uridine 10 showing the atom labeling scheme. $\mathrm{H}$-atoms and interstitial $\mathrm{H}_{2} \mathrm{O}$ molecules are omitted for clarity.

14. Ball-and-stick representation of 1- $N$-benzyl-5-(1-propanethiovinyl)uracil 45 showing the atom labeling scheme. Disordered parts and $\mathrm{H}$-atoms are not shown for clarity

15. Ball-and-stick representation of 1- $N$-benzyl-5-(2-tosylacetyl)uracil (49); $\mathrm{H}$-atoms have been hidden for clarity 
16. Incorporation of ( $\beta$-chloro)vinyl sulfone analogue into DNA open

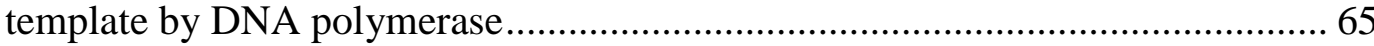

17. Incorporation of ( $\beta$-chloro)vinyl sulfone analogue into DNA one gap

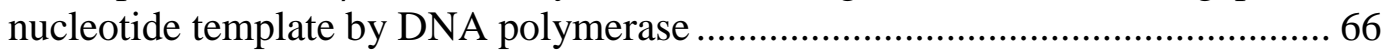

18. Incorporation of 5 ( $\beta$-keto)sulfone analogue into DNA open template by DNA polymerase

19. Incorporation of ( $\beta$-keto)sulfone analogue into DNA one nucleotide gap template by DNA polymerase

20. Lipophobic (9) and lipophilic (9a) 5-modified-2' deoxynucleoside analogues ... 72 


\section{LIST OF SCHEMES}

SCHEME

PAGE

1. Synthesis of $(E)$-( $\beta$-chloro)vinyl sulfone analogue from aryl acetylene using aryl sulfonyl chloride by Eiichi Nakamura's group

2. Synthesis of $(E)$-( $\beta$-chloro/bromo)vinyl sulfone by transition metal catalyzed halosulfonylation reaction by Xiangseng Xu's group . 8

3. Plausible mechanism of iron(III) halide-mediated halosulfonylation reactions to afford $(E)-\beta$-(chloro/bromo)vinyl sulfones ${ }^{43}$

4. Synthesis of $(E)$-( $\beta$-iodo)vinyl sulfone via iodine mediated halosulfonylated reaction by Xiaoqing Li's group

5. Synthesis of $(E)$-( $\beta$-iodo)vinyl sulfone using sodium salt of $\mathrm{p}$ toluenesulfinic acid

6. Synthesis of $(E)$-( $\beta$-bromo/iodo)vinyl sulfones via $\mathrm{N}$-bromo/iodo succinamide mediated halosulfonylation reaction ......................................... 10

7. Plausible mechanism of NIS promoted iodosulfonylation of aryl alkynes ${ }^{44} \ldots \ldots . . .10$

8. Synthesis of $(E)-\beta$-iodovinylsulfone via iodine and DTBP promoted reaction by Zhao et al.

9. Synthesis of $\beta$-keto sulfones with alkyne moiety at the carbonyl carbon

10. Synthesis of $\beta$-keto sulfone with paracyclophane moiety.

11. Synthesis of $\beta$-keto sulfone from sulfonyl allene attached at $3^{\prime}$ postion of 2'-deoxythymidine nucleoside

12. Synthesis of $\beta$-keto sulfone from alkene via IBX/I $\mathrm{I}_{2}$ mediated reaction.

13. Synthesis of $\beta$-keto sulfones by $p$-toluenesulfonic acid catalyzed reaction 14

14. Synthesis of $\beta$-keto sulfones from acid sensitive acetylene precursors

15. Synthesis of $\beta$-keto sulfones via pyridine catalyzed dioxygen triggered oxidative radical process

16. Mechanism of synthesis of aryl ( $\beta$-keto)sulfone via pyridine catalyzed dioxygen triggered oxidative radical reaction. 
17. Knoevengal condensation of $\beta$-keto sulfones to afford $(E)-\alpha-$ benzylsulfonyl chalcone derivatives

18. Pd-catalyzed allylic alkylation of phenylsulfonyl acetophenone for the synthesis of $E$-stereoselective $\alpha$-monoallylated $\beta$-keto sulfone. 16

19. Pd-catalyzed arylation at $\alpha$-position of phenylsulfonyl acetophenone 17

20. Alkylation of $\beta$-keto sulfones with 1-alkylpyrrolidine-2-thione methyl iodide salts for the synthesis of $\beta$-sulfonyl substituted enamines

21. Alkylation of $\beta$-keto sulfones with $N$-[1-acetoxy-2,22-trichloro)ethyl] urea to afford arylsulfonyl-substituted tetrahydropyrimidin-2(1H)-ones.

22. Synthesis of 1,3-oxazolidine by the reaction of nonaflyl acetone with $\beta$ chloroethyl isocyanate 18

23. Synthesis of $\alpha$-diazo $\beta$-keto sulfones 19

24. Chemoselective $\alpha$-mono and di-halogenation at the $\alpha$-carbon of $\beta$-keto sulfones

25. Synthesis of $\alpha$-Iodo $\beta$-keto sulfone using iodine monochloride or iodine 19

26. Synthesis of $\alpha$-tosyloxy $\beta$-keto sulfone via solvent free reaction 20

27. Incorporation of methylthiol moieties at $\alpha$-position of $\beta$-keto sulfones by Mannich type reaction

28. Synthesis of $(E) \beta$-ferrocenyl- $\alpha, \beta$-unsaturated sulfone via Friedel-Crafts type reaction

29. Asymmetric borane reduction of $\beta$-keto sulfones for convertion into $\beta$ hydroxy sulfones.

30. Synthesis of $N$-substituted triazoles from $\beta$-keto sulfones via base catalyzed Dimroth reaction

31. Synthesis of $N$-substituted triazoles from $\beta$-keto sulfones using pyrolidine

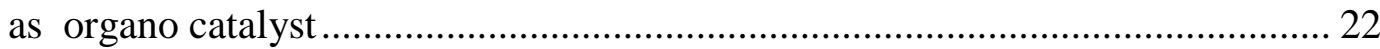

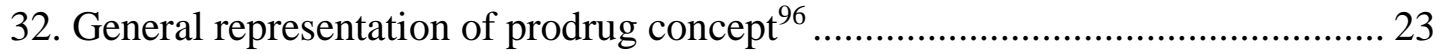

33. Incorporation of reactive acetylene group at 5 position of uracil nucleosides .... 29

34. Synthesis of (E)-5-(1-chloro/bromo-2-tosylvinyl)uracil nucleosides via iron catalyzed halosulfonylation reaction. 30 
35. Synthesis of (E)-5-(1-iodo-2-tosylvinyl)uracil nucleosides via NIS promoted halosulfonylation reaction

36.Synthesis of acetyl protected 5-ethynylcytidine and 2'-deoxycytidine analogues.

37. Synthesis of $(E)$ - $\beta$-chlorovinyl sulfone of protected cytidine and 2'deoxycytidine nucleosides

38. Displacement of halogen atoms of uracil nucleosides by thiolates and amino acid to afford analogues with retention of configuration

39. Conjugation of 5- ( $\beta$-chloro)vinyl sulfone of 2'-deoxyuridine with Lglutathione via displacement reaction.

40. Substitution of halogen atoms of 5-( $\beta$-halovinyl) sulfone of uridine and 2 '-deoxyuridine with amino group.

41. Plausible mechanism for the substitution of chlorine atom by amino group in $(\beta$-halo)vinyl sulfones 36

42. Synthesis of (E)-5-(2-tosylvinyl)uridine. 39

43. Deuterium exchange at vinylic proton of 5- ( $\beta$-aminovinyl) sulfone of uridine to afford $\alpha$-deuterated analogue

44. Deuterium exchange at the vinylic proton of $\beta$-chloro analogue

45. Deuterium exchange at vinylic proton of $\beta$-chloro sulfone to give $\alpha$ deuterated $\beta$-propanethio-analogue.

46. Plausible mechanism for substitution of halogen in $\beta$-halovinyl sulfones with nucleophiles 43

47. Synthesis of $\beta$-keto sulfone from $\beta$-chloro vinyl sulfone analogue via substitution by ammonia and acid hydrolysis....

48. Plausible mechanism of the conversion of $\beta$-amino sulfone into $\beta$-keto sulfone.

49. General scheme for the trapping of eletrophiles at the $\alpha$-carbon of $\beta$-keto sulfone 48

50. Plausible mechanism of electrophile trapping at the $\alpha$ - carbon 48

51. Synthesis of 5-( $\beta$-keto)sufone of 1- $N$-benzyl-5-ethynyluracil 49 
52. Synthesis of 5-( $\beta$-keto)sufone of protected uridine from the corresponding 5-ethynyl substrates

53. Synthesis of 5-( $\beta$-keto)sulfone of uridine and 2'-deoxyuridine from their ( $\beta$-chlorovinyl) sulfone analogue

54. Incorporation of electrophiles at the $\alpha$-carbon of ( $\beta$-keto) sulfone of uridine and 2'-deoxyuridine

55. Synthesis of 5-( $\alpha$-iodo $\beta$-keto sulfone) of 2'-deoxyuridine. 55

56. Synthesis of 5- ( $\alpha$-propanethio $\beta$-keto sulfone) of 2'-deoxyuridine 56

57. Synthesis of 5-( $\beta$-keto)sulfone of cytidine and 2'-deoxycytidine 57

58. Synthesis of 5-( $\alpha$-subsitituted $\beta$-keto sulfone $)$ of cytidine and 2deoxycytidine. 58

59. Synthesis of protected 8-acetylene 2'-deoxyadenosine

60. Attempted halosulfonylation of 8-ethynyl -2'-deoxyadenine 23 with tosyl hydrazide. Synthesis of 8-(1-chloro-2-tosylvinyl)adenine 60

61. Synthesis of 8-( $\beta$-iodovinyl)sulfone analogue of 2'-deoxyadenosine 61

62. Synthesis of 5'-monophosphate of 5-( $\beta$-chlorovinyl sulfone) of $2^{\prime}$ deoxyuridine by modified Yoshikawa method 62

63. Synthesis of 5'-triphosphate of 5-(1-chloro-2-tosylvinyl)-2'-deoxyuridine 63

64. Conjugation of 5-( $\beta$-chlorovinyl sulfone) of 2'-deoxyuridine-5'monophosphate with L-glutathione

65. 5'-Phosphorylation of 5-(2-tosylacetyl)-2'-deoxyurindine 68

66. Preparation of undecanoic anhydride from undecanoic acid 72

67. Synthesis of undecanoate protected 5-(1-chloro-2-tosyl)vinyl-2'deoxyuridine 73

68. Synthesis of 5-(fur-2-yl)/5-(heptafur-2-yl)-2'-deoxyuridine by direct arylation and their undecanoate protected analogues 


\section{LIST OF ABBREVIATIONS}

5'-araCTP 5'-arabinofuranosylcytosine triphosphate

5-FdU 5-fluoro-2'-deoxyuridine

5-FU 5-fluorouracil

Abs absorbance

Ar

aromatic (NMR)

AZT 3'-Azido-3'-deoxythymidine

$\alpha$

alpha

$\beta$

beta

$\mathrm{Bn}$

benzyl

br

broad (NMR)

BVDU (E)-5-(2-bromovinyl)-2'-deoxyuridine

$t-\mathrm{Bu}$

tert-butyl

calcd

calculated (HRMS)

CID

collision-induced dissociation (HRMS)

${ }^{\circ} \mathrm{C}$

degrees Celsius

$\delta$

delta

d

doublet (NMR)

DCE

1,2 dichloro methane

DCM

dichloromethane

dCK deoxycytidine kinase 


\begin{tabular}{|c|c|}
\hline $\mathrm{dCTP}$ & deoxycytidine triphosphate \\
\hline DMAP & 4-(N,N-dimethylamino)pyridine \\
\hline DMF & $N, N$-dimethylformamide \\
\hline DMSO & dimethylsulfoxide \\
\hline DNA & deoxyribonucleic acid \\
\hline DTBP & Di-tert-butyl peroxide \\
\hline ESI & electrospray ionization \\
\hline Et & ethyl \\
\hline FDA & U.S. Food and Drug Administration \\
\hline FUra & 5-fluorouracil \\
\hline$\lambda$ & lambda \\
\hline $\mathrm{g}$ & $\operatorname{gram}(\mathrm{s})$ \\
\hline $\mathrm{h}$ & hour(s) \\
\hline HBV & hepatitis B virus \\
\hline HIV & human immunodeficiency virus \\
\hline HSV & herpes simplex virus \\
\hline HPLC & high performance liquid chromatography \\
\hline HRMS & high resolution mass spectroscopy \\
\hline $\mathrm{Hz}$ & hertz \\
\hline$J$ & coupling constant in $\mathrm{Hz}$ (NMR) \\
\hline $\mathrm{L}$ & liter(s) \\
\hline
\end{tabular}




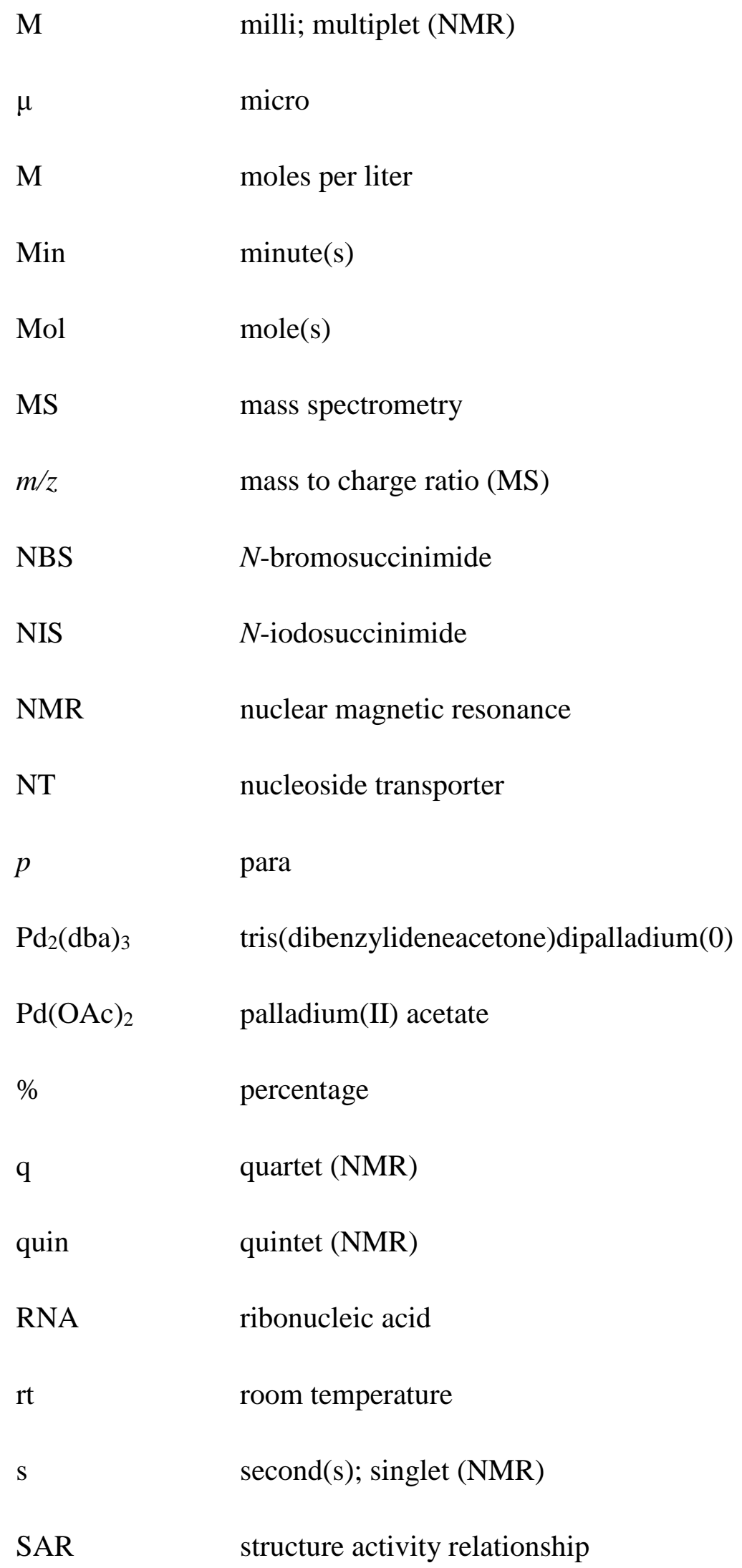




$\begin{array}{ll}\text { SET } & \text { single electron transfer } \\ \text { sex } & \text { sextet } \\ \text { T } & \text { triplet (NMR) } \\ \text { TBAF } & \text { tetra- } N \text {-butylammonium fluoride } \\ \text { TBHP } & t \text {-Bu hydroperoxide } \\ \text { TEA } & \text { triethylamine } \\ \text { THF } & \text { tetrahydrofuran } \\ \text { TK } & \text { thymidine kinase } \\ \text { TLC } & \text { thin layer chromatography } \\ \text { TMS } & \text { trimethylsilyl } \\ \text { V } & \text { vaccinia virus } \\ & \text { retention time (HPLC) } \\ & \text { versus } \\ & \end{array}$




\section{INTRODUCTION}

\subsection{Importance of nucleosides and nucleotides}

Nucleosides are the glycosyamines which possess a $\beta$-glycosidic bond between the base and the sugar moiety while nucleotides additionally have one or more phosphate groups at the sugar moiety. Nucleosides can be converted into nucleotides inside the cell by nucleoside kinases which are the basic building blocks of deoxyribonucleic acid (DNA) and ribonucleic acid (RNA). Both DNA and RNA are the source of life in living cells where DNA carries the message. The discovery of the double helix structure of DNA by Watson and Crick is the milestone for the development of modern nucleoside and nucleotide chemistry. Both nucleosides and nucleotides play key roles in DNA and RNA replication which is critical for cell proliferation. Specific nucleoside transporters transport nucleoside analogues inside the cells where they are phosphorylated by nucleoside kinases. ${ }^{1,2}$ The phosphorylated nucleoside analogues are incorporated into DNA by DNA polymerase catalyzed reaction and thus induce the termination of chain elongation, ${ }^{3}$ the accumulation of mutation ${ }^{4-6}$ as well as apoptosis. ${ }^{7,8}$ So, through the modification of either the base or sugar moiety, nucleosides can inhibit the carcinogenic cell proliferation and viral DNA and RNA replication thus captivate attention to study as a precursor molecule in chemistry and biology.

\subsubsection{Nucleoside analogues as anticancer drugs}

Both pyrimidine and purine nucleoside analogues serve as potent anticancer drugs. For example cytarbine contributes to cure amyeloid leukeamia ${ }^{9}$, while 6-mercaptapurine is

efficacious against acute lymphoblastic leukaemia. ${ }^{10}$ Gemcitabine, a bifluorinated pyrimidine nucleoside derivative is very active against haematological malignancy and different solid tumors. ${ }^{11}$ So far 14 nucleoside analogues have been approved by the US Food and Drug 
Administration (FDA) for the treatment of cancer which is $10 \%$ of the total cancer drugs available in the market. In addition a couple of nucleoside analogues such as Sapacetabine, ${ }^{12}$ 8-chloro-adenosine, ${ }^{13,14} 8$-amino adenosine ${ }^{15}$ are waiting for the approval of FDA.

Table 1. FDA approved anticancer purine and pyrimidine nucleoside analogues ${ }^{16}$

\begin{tabular}{|l|l|c|}
\hline \multicolumn{1}{|c|}{ Drug } & Category & Year \\
\hline 6-mercaptopurine (Purinethol) & Purine & 1953 \\
\hline 5-fluorouracil (Adrucil) & Uracil & 1962 \\
\hline 6-thioguanine (Lanvis) & Guanine & 1966 \\
\hline arabinofuranosylcytosine (Cytarabine) & Cytidine & 1969 \\
\hline 5-fluoro-2'-deoxyuridine (Floxuridine) & 2'-Deoxyuridine & 1970 \\
\hline arabinofuranosyl-2-fluoroadenine (Fludarabine) & Purine analogue & 1991 \\
\hline 2'-deoxycoformycin (Pentostatin) & Adenosine & 1991 \\
\hline 2-chloro-2'-deoxyadenosine (Cladribine) & 2'Deoxyadenosine & 1992 \\
\hline 2,2-difluoro-2'-deoxycytidine (Gemcitabine) & 2'-Deoxycytidine & 1996 \\
\hline $\begin{array}{l}N^{4} \text {-pentyloxycarbonyl-5'-deoxy-5-fluorocytidine } \\
\text { (Capecitabine) }\end{array}$ & Cytidine & 1998 \\
\hline $\begin{array}{l}\text { 2'-fluoro-2'-deoxyarabinofuranosyl-2-chloroadenine } \\
\text { (Clofarabine) }\end{array}$ & Cytidine & 2004 \\
\hline 5-aza-cytidine (Azacitidine) & 2'-Deoxyadenosine & 2004 \\
\hline$O^{6}$-methylarabinofuranosyl guanine (Nelarabine) & Guanosine & 2005 \\
\hline 5-aza-2'-deoxycytidine (Decitabine) & 2'-Deoxycytidine & 2006 \\
\hline
\end{tabular}

\subsubsection{Nucleoside analogues as antiviral drugs}

Nucleoside analogues are well-known drugs because of their capability to treat a variety of viral infected patients including Hepatitis C virus (HCV), Hepatitis B virus (HBC), Human immunodeficiency virus (HIV), Herpes simplex virus (HSV), Varicella zoster virus (VZV), and Influenza virus. Several 2'-deoxy-2'-fluorocytidine (FdC) derivatives are well-known anti-HCV compounds such as methylated form of FdC (PSI-6130) can effectively inhibit the 
genotype $1 \mathrm{~b}$ HCB subgenomic replicon system. ${ }^{17}$ Mericitabine in combination with pegylated interferon and ribavirin and or a first -generation protease inhibitor is very active to inhibit hepatitis C viral replication. ${ }^{18,19}$ Elvucitabine and Apricitabine are potent inhibitor of human immunodeficiency viral (HIV) replication..$^{20,21}$ Festinavir which is also known as BMS986001 is a chemically modified first generation anti-HIV nucleoside analogue stavudine increased potency and reduced mitochondrial toxicity. ${ }^{22,23}$ Cyclopropavir which as a guanosine derivative and structurally related to actyclovir and ganciclovir is active against many herpesveuses including human cytomegalovirusm human herpesvirus 6A, human herpesvirus $6 \mathrm{~B}$ and human herpesvirus $8 .{ }^{24,25}$ Because of the potency against a wide range of herpes simplex virus, many protides of cyclopropavir have been synthesized and their antiviral activities are under investigation. ${ }^{26}$

Table 2. Antiviral properties of purine and pyrimidine nucleoside analogues ${ }^{27}$

\begin{tabular}{|l|l|l|}
\hline \multicolumn{1}{|c|}{ Drug } & Category & Year \\
\hline 5-iodo-2'-deoxyuridine (Idoxuridine & Uridine & 1962 \\
\hline 5-ethyl-2'-deoxyuridine (Edoxudine) & Thymidine & 1969 \\
\hline 9- $\beta$-D-arabinofuranosyladenine (Vidarabine) & Adenosine & 1976 \\
\hline (E)-5-(2-bromovinyl)-2'-deoxyuridine (Brivudine) & Uridine & 1980 \\
\hline $\begin{array}{l}\text { 2-amino-1,9-dihydro-9-[(2- } \\
\text { hydroxyethoxy)methyl]-6H-purin-6-one }\end{array}$ & Guanosine & 1982 \\
\hline 3'-azido-3'-deoxythymidine (Zidovudine) & Thymidine & 1987 \\
\hline 2',3'-didehydro-2',3'-dideoxythymidine (Stavudine) & Thymidine & 1994 \\
\hline 2',3'-dideoxy-3'-thiacytidine (Lamivudine) & Cytidine & 1998 \\
\hline 2',3'-didehydro-2',3'-dideoxythymidine (Stavudine) & Thymidine & 2001 \\
\hline $\begin{array}{l}\text { 4-Hydroxy-3-(hydroxymethyl)-2- } \\
\text { methylidenecyclopentylguanosine }\end{array}$ & Thymidine & 2005 \\
\hline
\end{tabular}




\begin{tabular}{|l|l|c|}
\hline $\begin{array}{l}\text { 5-fluoro-1-(2R,5S)-[2-(hydroxymethyl)-1,3- } \\
\text { oxathiolan-5-yl]cytosine }\end{array}$ & Cytidine & 2006 \\
\hline $\begin{array}{l}\text { Tenofovir disoproxil fumarate, mixture of purine } \\
\text { analogues (Tenofovir) }\end{array}$ & Purine & 2008 \\
\hline $\begin{array}{l}\text { 2'-deoxy-2'-fluoro-2'-methyluridine-5'-phosphate } \\
\text { (Sofosbuvir) }\end{array}$ & Thymidine & 2013 \\
\hline
\end{tabular}

\subsection{5-Modified pyrimidine nucleosides as reactive probes for bioconjugation}

Considering the importance of bioconjugation in medicinal chemistry, chemical biology, nanotechnology, and material sciences, a considerable amount of effort has been given to connect new probes of nucleotides with peptides, proteins, and other biomolecule. ${ }^{28}$ The bioconjugation strategy enables us to link important modified biomolecules to study chemical reactions on living cells, which can be crucial to verify the credibility of the anticancer or antiviral properties of the corresponding compound. ${ }^{29}$ Bioconjugation is a useful chemical strategy to study DNA-protein interactions. ${ }^{30}$ Attachment of reactive functionalities such as alkyne, alkene, azide, diene, or aldehyde at the base moiety of nucleosides/nucleotides and their incorporation into DNA offer good programmability to connect the modified DNA with important biomolecules. These functionalities allowed the modified DNA to tether with other biomolecules via click chemistry, ${ }^{31}$ Straudinger ligation, ${ }^{32}$ Diels-Alder reactions ${ }^{33}$ etc.

Some of the notable works in bioconjugation have been done by Hocek's lab who introduced aldehyde functionality at 5 position of cytidine nucleotide and incorporated them into DNA and subsequently stained with 2,4-dintrophenyl hydrazine (2,4-DNPH) or nitrobenzofurazanehydrazine via hydrazone formation. ${ }^{34}$ He also tethered reactive aldehyde functional group containing formaryl moieties at 5 position of 2'-deoxycytidine nucleotides which incorporated via polymerase incorporation. The reactive aldehyde functional group containing modified DNA was connected with amino acid lysine and peptides. ${ }^{35}$ Recently Dr. 
Hocek attached acrylamide and vinylsulfonamide to the 5 position of cytidine triphosphate and incorporated them into DNA via DNA polymerase. Later he did bioconjugation of these vinylsulfonamide and acrylamide modified DNA with the tumor-suppressor protein p53. ${ }^{36}$ These bioconjugations have been taken place via Michael addition reactions where the modified DNA acts as a Michael acceptor while the protein p53 acts as a Michael donor.

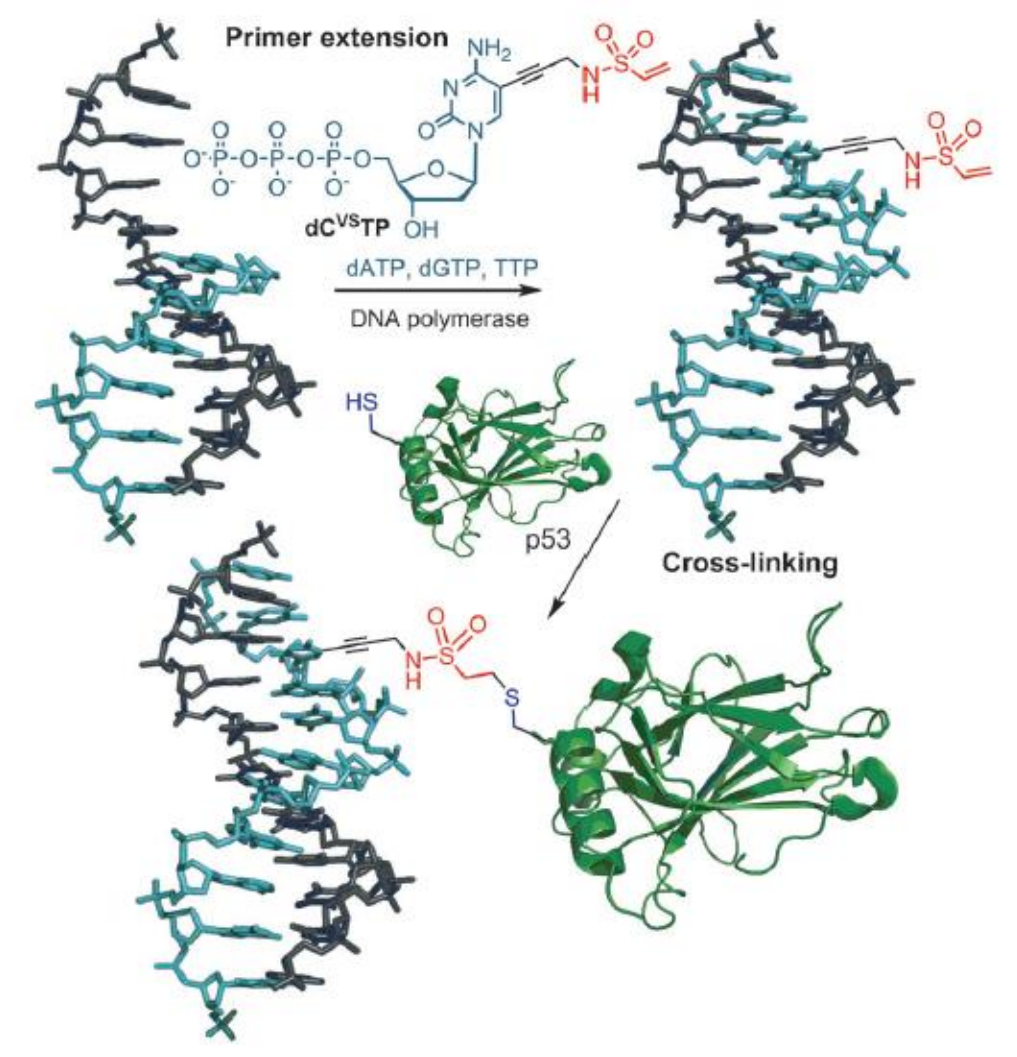

Figure 1. Synthesis of vinylsulfonamide modified DNA by PEX and its cross-linking with p53 protein $^{36}$

From all of the examples of bioconjugation, we have been inspired to link the ( $\beta$ halo)vinyl sulfone modified DNA with amino acid cysteine or proteins having thiol or amine residues. The 5-modified 2'-deoxypyrimidine nucleoside analogues modified with ( $\beta$ halo)vinyl sulfone will be an excellent probe in bioconjugate chemistry as they are very susceptible to different nucleophiles (amine, cysteine etc.) and readily give product via 
addition-elimination reaction. So, our first goal is to synthesize triphosphorylated pyrimidine nucleoside analogues having ( $\beta$-halo)vinyl sulfone tethered at 5 postion of the nucloebase to polymerase catalyzed incorporation into DNA. Next, we want to link this modified DNA with amino acid cysteine or protein having amino or thiol residue which will efficiently react with ( $\beta$-halo)vinyl sulfone through addition-elimination reactions. Note that Michal Hocek did similar types of bionconjugation via Michael addition reaction but our conjugation is totally different and occurs via an addition-elimination process. The 5' position of pyrimidine nucleoside analogues modified with ( $\beta$-halo)vinyl sulfone, polymerage mediated incorporation in DNA and subsequent treatment of this modified DNA with suitable protein (having amino or thiol residues) will efficiently give bio-conjugated product via additionelimination mechanism. In summary, phosphorylation at 5' position of pyrimidine nucleoside analogues modified with ( $\beta$-halo)vinyl sulfone, polymerase mediated incorporation in DNA and subsequent treatment of this modified DNA with suitable protein will give our desired bio-conjugated product.

\subsection{Overview of $(\beta$-halo)vinyl sulfone}

The ( $\beta$-halo)vinyl sulfones having halogen atom at the $\beta$-positions of the vinyl functional group are important precursurs due to their capabilities of serving as synthetic intermediate in

organic chemistry. ${ }^{37,38}$ Moreover, owing to the presence of reactive functional groups, and biologically important $\mathrm{C}-\mathrm{S}$ bond, it has drawn considerable amount of attention to explore their biological activities. ${ }^{39}$ 


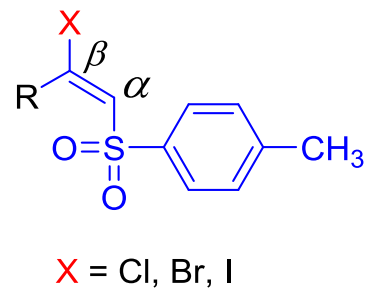

Figure 2. General structure of ( $\beta$-halo)vinyl sulfones

\subsubsection{Synthesis}

Terminal alkyne functional group offers unique opportunity to synthesize regio and stereoselective ( $\beta$-halo)vinyl sulfone. ${ }^{40}$ The Eiichi Nakamura group developed Iron-catalyzed and phosphine ligand-mediated regio and stereoselective chlorosulfonylation reaction. Thus, treatment of terminal alkyne substrate A with aryl sulfonyl chloride in the presence of iron (II) acetate and tri( $p$-tolyl)phosphine and affords $(E)$-( $\beta$-chloro)vinyl sulfone $\mathbf{B}$ with excellent yield (Scheme 1). ${ }^{41}$

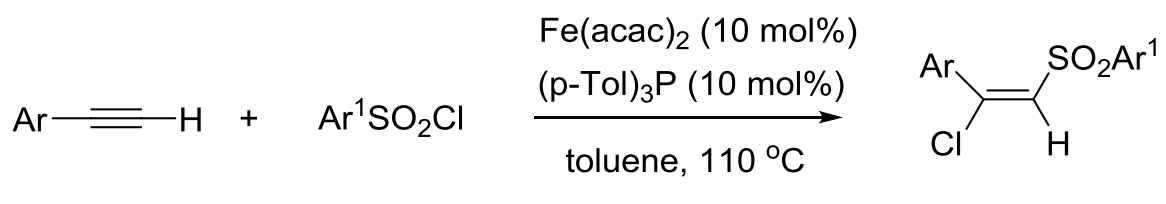

A

B

Scheme 1. Synthesis of (E)-( $\beta$-chloro)vinyl sulfone analogue from aryl acetylene using aryl sulfonyl chloride by Eiichi Nakamura's group

Sulfonyl hydrazide is a well-known source of sulfonyl moiety and widely used reagent during the halovinylsulfonylation reaction. ${ }^{42}$ Xiangsheng Xu's group developed transition metal catalyzd regio and stereoselective halosulfonylation reaction to synthesize $(E)-(\beta$ chloro/bromo)vinyl sulfone $\mathbf{B}$ by the treatment of phenyl acetylene A with p-tolyl sulfonyl hydrazide in the presence of iron(III) halides and TBHP afford the halovinyl sulfone $\mathbf{B}$ (Scheme 2). ${ }^{43}$ 


$$
\mathrm{Ph}=\mathrm{H}+\mathrm{ArSO}_{2} \mathrm{NHNH}_{2}
$$

A

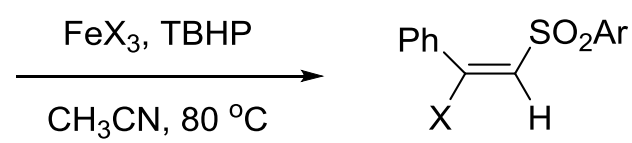

B

$$
\mathrm{X}=\mathrm{Cl}, \mathrm{Br}
$$

Scheme 2. Synthesis of $(E)-(\beta$-chloro/bromo)vinyl sulfone by transition metal catalyzed halosulfonylation reaction by Xiangseng Xu's group

The plausible mechanism of the reaction can be explained by the interaction of tertiary butyl hydroperoxide with iron(III) halide generates tertiary butyl peroxide radical I (Scheme 3). The resulting peroxide radical generates tosyl radical III from tosyl hydrazide through the removal of nitrogen gas. Attack on the alkyne group by the reactive tosyl radical and subsequent interaction with iron (III) halide generates regio and stereoselective products $(E)$ $\beta$-chloro/bromovinyl sulfone IV (Scheme 3).

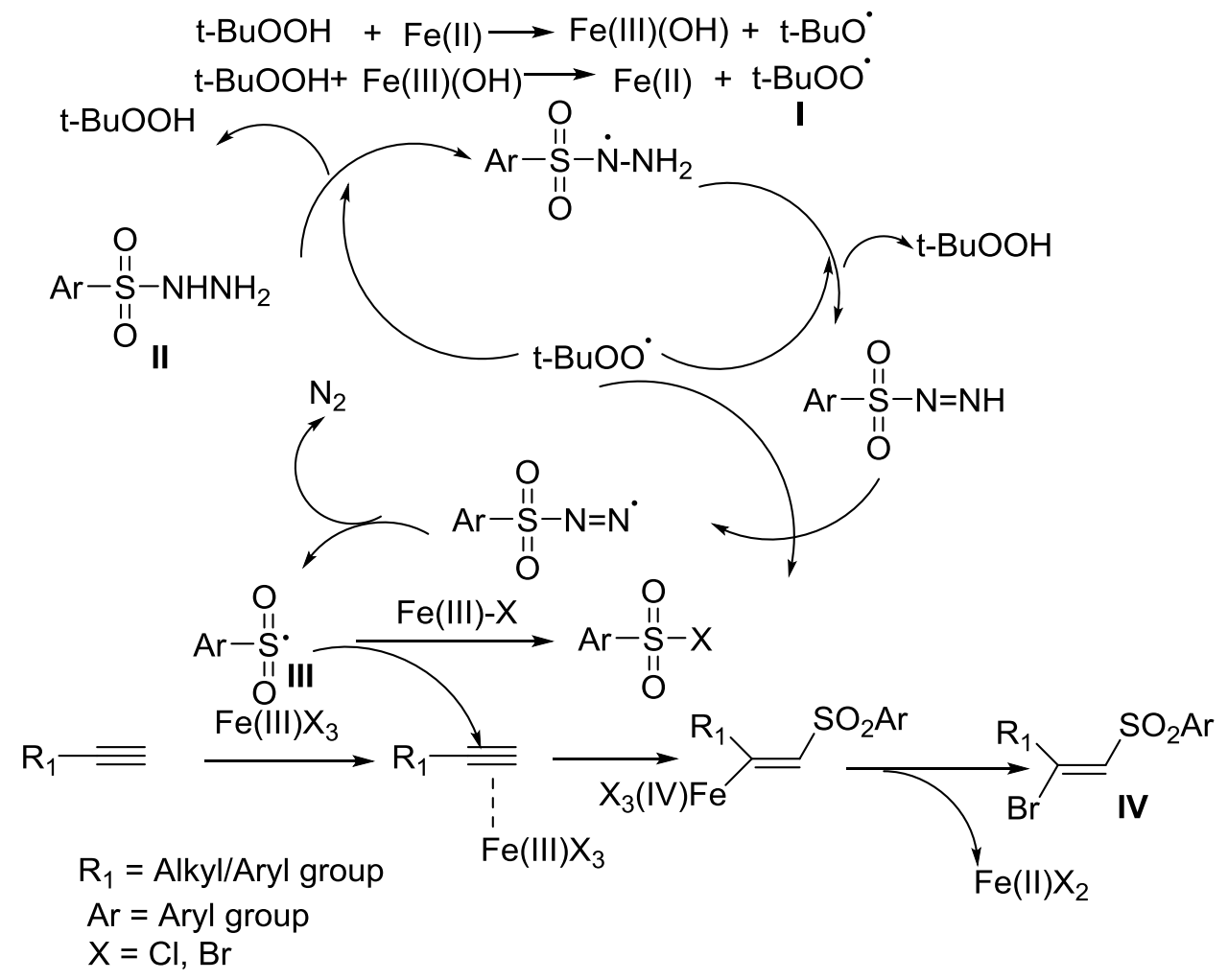

Scheme 3. Plausible mechanism of iron(III) halide-mediated halosulfonylation reactions to afford $(E)-\beta$-(chloro/bromo) vinyl sulfones ${ }^{43}$ 
Xiaoqing Li's group successfully synthesized $(E)$-( $\beta$-iodo)vinyl sulfone using $\mathrm{I}_{2}$ instead of iron halides ${ }^{44}$ as depicted below in Scheme 4. In this reaction interaction of tertiary butyl hydroxyl radical with tosyl hydrazide generates tosyl radical. Subsequent interaction of tosyl radical and iodine with alkyne moiety gives $(E)$-( $\beta$-iodo)vinyl sulfone (Scheme 4).

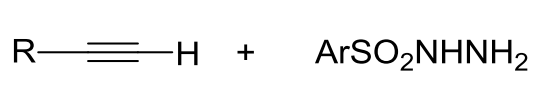

A

$\mathrm{R}=$ Alkyl, aryl

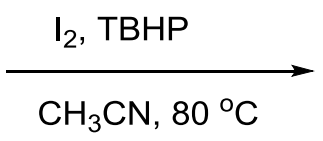

$\mathrm{CH}_{3} \mathrm{CN}, 80^{\circ} \mathrm{C}$

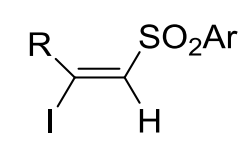

B

Scheme 4. Synthesis of (E)-( $\beta$-iodo)vinyl sulfone via iodine mediated halosulfonylated reaction by Xiaoqing Li's group

Treatment of terminal alkyne probes with sodium salt of p-toluene sulfinic acid and iodine in the presence of sodium acetate afford $(E)$ - $\left(\beta\right.$-iodo)vinyl sulfone as shown in Scheme $5 .{ }^{45}$

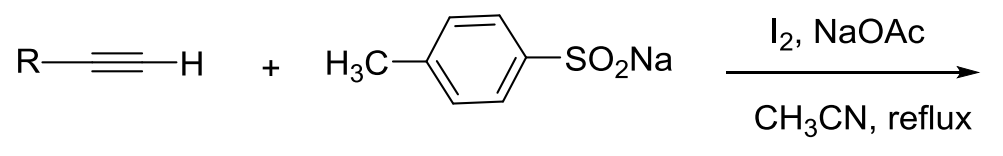

A

$\mathrm{R}=\mathrm{Alkyl}$, aryl

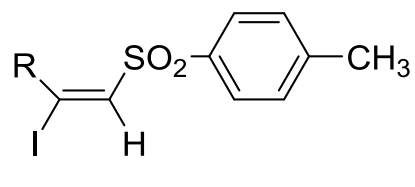

B

Scheme 5. Synthesis of $(E)$-( $\beta$-iodo)vinyl sulfone using sodium salt of $\mathrm{p}$-toluenesulfinic acid

$\mathrm{N}$-halosuccinimide (NXS) promoted halosulfonylation of terminal alkyne give $(E)-(\beta$ bromo/iodo)vinyl sulfones. Treatment of aryl acetyle $\mathbf{A}$ with sodium tosylate and $\mathrm{N}$-halo succinamides (NXS) affords $E$ )-( $\beta$-bromo/iodo)vinyl sulfones $\mathbf{B}$ as depicted in Scheme $6 .{ }^{46}$ 


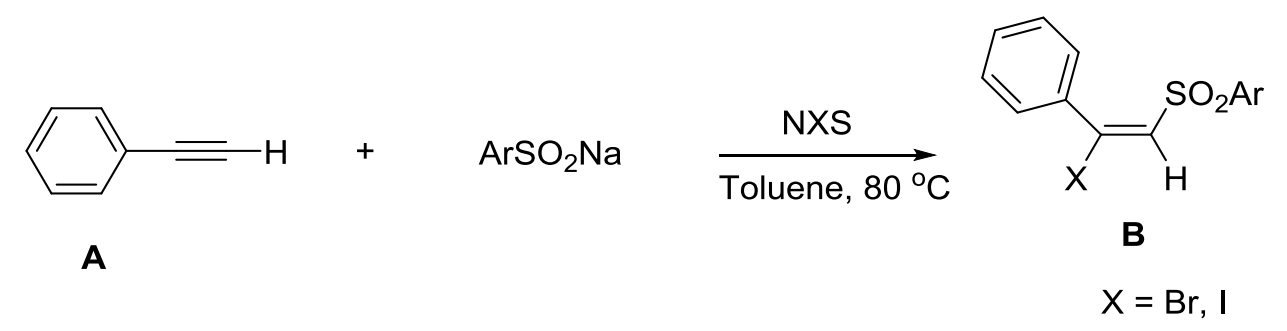

Scheme 6. Synthesis of (E)-( $\beta$-bromo/iodo)vinyl sulfones via $\mathrm{N}$-bromo/iodo succinamide mediated halosulfonylation reaction

The plausible mechanism of the reaction can be explained by the formation of the iodide radical I and succinamide radical by the hemolytic cleavage of N-I bond of NIS in the initiating step (Scheme 6). Later, tosyl radical II is formed by single electron transfer with the help of succinamide radical and subsequent regio and stereoselective interaction of these tosyl radical II and iodide radical $\mathbf{I}$ with the terminal alkyne moiety gives $(E)$ - $\beta$-iodovinylsulfone compound III (Scheme 7).

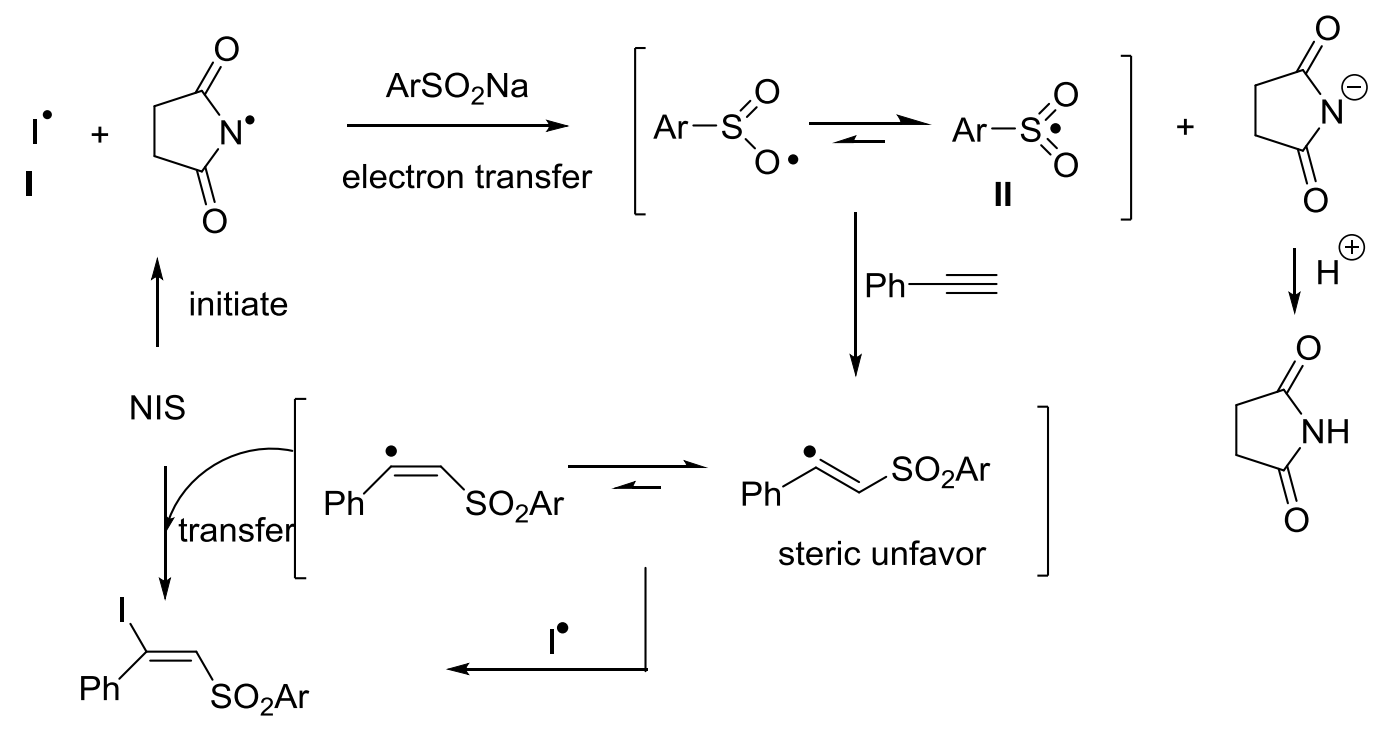

III

Scheme 7. Plausible mechanism of NIS promoted iodosulfonylation of aryl alkynes ${ }^{44}$

Iodine and di-tert-butyl peroxide (DTBP) promototed difunctionalization of terminal alkyne $\mathbf{A}$ with sodium benzene sulfinates afforded $(E)$ - $\beta$-iodovinylsulfone $\mathbf{B}$ with excellent yield (Scheme 8). ${ }^{47}$ 


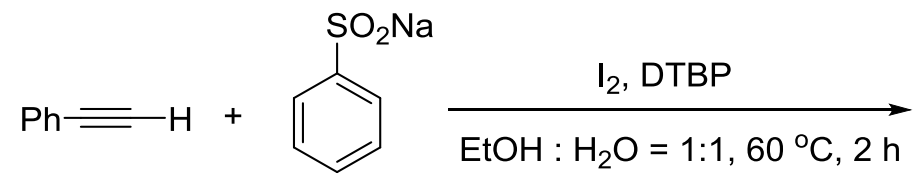

A

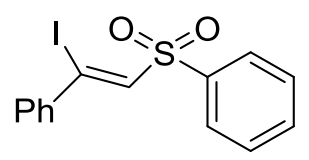

B

Scheme 8. Synthesis of (E)- $\beta$-iodovinylsulfone via iodine and DTBP promoted reaction by Zhao et al.

\subsubsection{Biological activity}

As vinyl sulfones are organosulfur compounds, the investigation of their biological activities is always fascinating to the medicinal chemists and biologists. Research shows that certain type of vinyl sulfone inhibits the replication of human immunodeficiency syndrome virus type 1 (HIV-1).$^{48}$ Vinyl sulfones also inhibit the protein degrading enzyme cathepsins L and B. ${ }^{49}$ It has been also reported that vinyl sulfones inhibits the activities of cysteine protease by binding the thiol residue of the enzymes via Michael addition reaction. ${ }^{50}$

\subsection{Overview of $\beta$-keto sulfone}

The $\beta$-keto sulfones also known as 2-oxo-sulfones is a class of organosulfur compound having active methylene group at the $\alpha$-position and carbonyl group at the $\beta$-position serves as a versatile synthetic site that can be used to synthesize different classes of organic compounds. ${ }^{51}$ Important natural products have been synthesized where $\beta$-keto sulfones acts a structural feature of the target substrate. In addition, certain types of $\beta$-keto sulfones exhibit important biological activities. Considering these diverse applicability, $\beta$-keto sulfones have drawn significant attention in chemistry in last few decades and occupied major parts in organosulfur chemistry. ${ }^{52}$ 


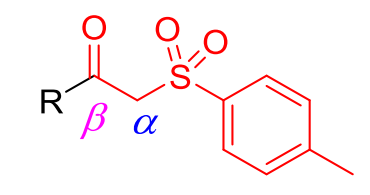

$\mathrm{R}=$ Alkyl, Aryl etc

Figure 3. General structure of ( $\beta$-keto)sulfone

\subsubsection{Synthesis}

$\beta$-Keto sulfones have been synthesized from various precursor molecules by using a wide varieties of reagents. ${ }^{53}$ Treatment of arylmethyl sulfone $\mathbf{A}$ with Grignard reagents generates arylsulfonyl methylene anion which attack at the carbonyl carbon of prop-2-ynals to give $\beta$ hydroxy sulfones B. Oxidation of these $\beta$-hydroxy sulfones by PCC give $\beta$-keto sulfones $\mathbf{C}$ with alkyne moiety at the carbonyl group (Scheme 9). ${ }^{54}$

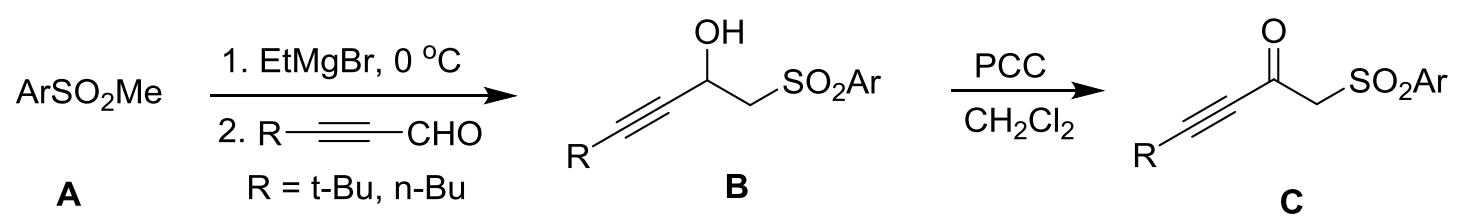

Scheme 9. Synthesis of $\beta$-keto sulfones with alkyne moiety at the carbonyl carbon

Treatment of 4-hydroxy-5-acyl[2.2]paracyclophane $\mathbf{A}$ with $\mathrm{NaH}$ and triflic anhydride or nonafluorobutanesulfonyl fluoride gives chiral[2.2]paracyclophane derivatives of $\beta$-keto sulfone $\mathbf{B}$ (Scheme 10) which is a potential ligand for asymmetric catalysis. ${ }^{55}$

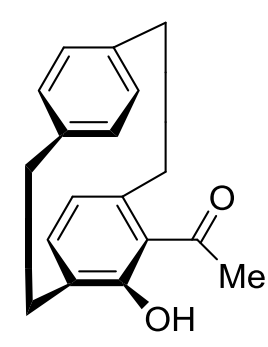

A
1. $\mathrm{NaH}(5 \mathrm{eq})$

2. $\mathrm{Tf}_{2} \mathrm{O}(\mathrm{PhMe})$ or NfF (DME)

0 oC to r.t, $24 \mathrm{~h}$

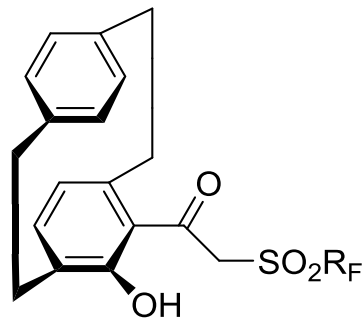

B

$$
\mathrm{R}_{\mathrm{F}}=\mathrm{CF}_{3} \text { or } \mathrm{C}_{4} \mathrm{~F}_{9}
$$

Scheme 10. Synthesis of $\beta$-keto sulfone with paracyclophane moiety 
The $\beta$-keto sulfone moiety attached at 3' position of thymidine analogue has been reported. ${ }^{56}$ Treatment of the allene sulfone $\mathbf{A}$ with piperidine at $\mathrm{rt}$ gives enamine sulfone intermediate $\mathbf{B}$ which convert to the $\beta$-keto sulfone $\mathbf{C}$ by hydrolysis (Scheme 11).

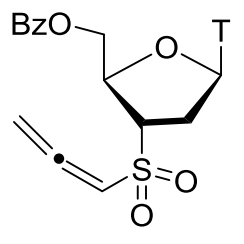

A

$T=$ Thymine

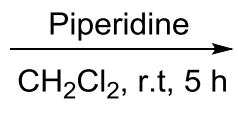

$\mathrm{CH}_{2} \mathrm{Cl}_{2}$, r.t, $5 \mathrm{~h}$

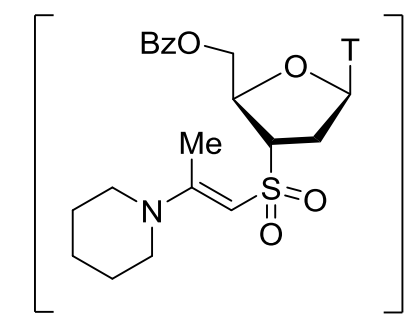

B

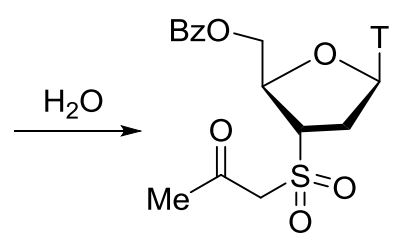

C

Scheme 11. Synthesis of $\beta$-keto sulfone from sulfonyl allene attached at 3' postion of 2'deoxythymidine nucleoside

The $\beta$-keto sulfone has been synthesized from aliphatic or aromatic alkenes by $\mathrm{IBX} / \mathrm{I}_{2}$ mediated reactions with sodium arene sulfinates ${ }^{57}$ Treatment of the alkene substrates $\mathbf{A}$ with sodium salt of p-toluenesulfinic acid efficiently affords the $\beta$-keto sulfone B (Scheme 12).

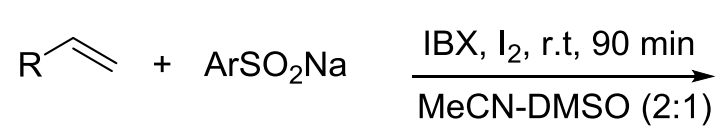

A<smiles></smiles>

B

$$
\mathrm{R}=\text { alkyl or } \mathrm{Ar}
$$

Scheme 12. Synthesis of $\beta$-keto sulfone from alkene via IBX/I $\mathrm{I}_{2}$ mediated reaction

Terminal alkyne is a convenient functional group for the synthesis of $\beta$-keto sulfone. Different research groups have synthesized $\beta$-keto sulfones reacting terminal alkyne probes with sulfonyl moiety containing precursors.

Hua's group successfully synthesized $\beta$-keto sulfones $\mathbf{B}$ by reacting aryl/heteroaryl acetylene substrates A with sulfonyl chloride and water in the presence of catalytic amount of $p$-toluenesulfonic acid as depicted in scheme $13 .^{58}$ 


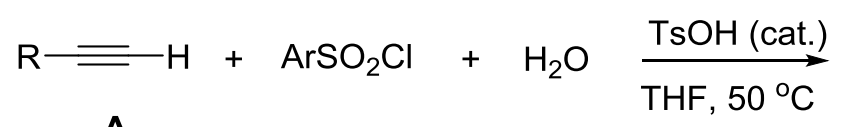

A

$\mathrm{R}=$ Aryl, heteroaryl<smiles>[R]C(=O)C[Se]O[Na]</smiles>

B

Scheme 13. Synthesis of $\beta$-keto sulfones by $p$-toluenesulfonic acid catalyzed reaction

The $\beta$-keto sulfones anologues $\mathbf{B}$ from acid sensitive acetylene precursors $\mathbf{A}$ have been synthesized using sodium salt of $p$-toluenesulfinic acid as shown in scheme 14. In this sulfonylation reaction nitroethane is used as solvent. ${ }^{59}$

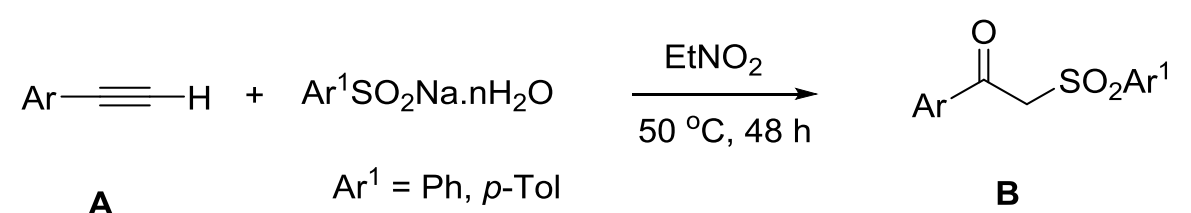

Scheme 14. Synthesis of $\beta$-keto sulfones from acid sensitive acetylene precursors Lei's group developed dioxygen triggered oxidative difunctionalization of terminal alkyne A gives $\beta$-keto sulfones $\mathbf{B}$ from good to excellent yield (Scheme 15). ${ }^{53}$ In this reaction pyridine acts a base and prevents atom transfer radical addition (ATRA) process to afford $\beta$ keto sulfone instead of vinyl sulfone.

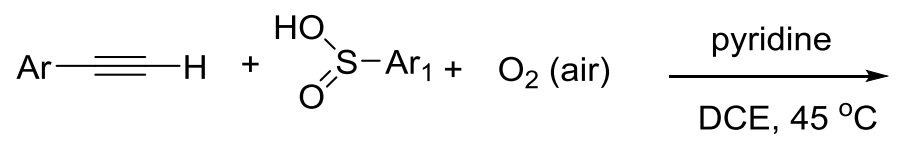

A<smiles>O=C([Al])C[Se]O[Mg]</smiles>

B

Scheme 15. Synthesis of $\beta$-keto sulfones via pyridine catalyzed dioxygen triggered oxidative radical process 

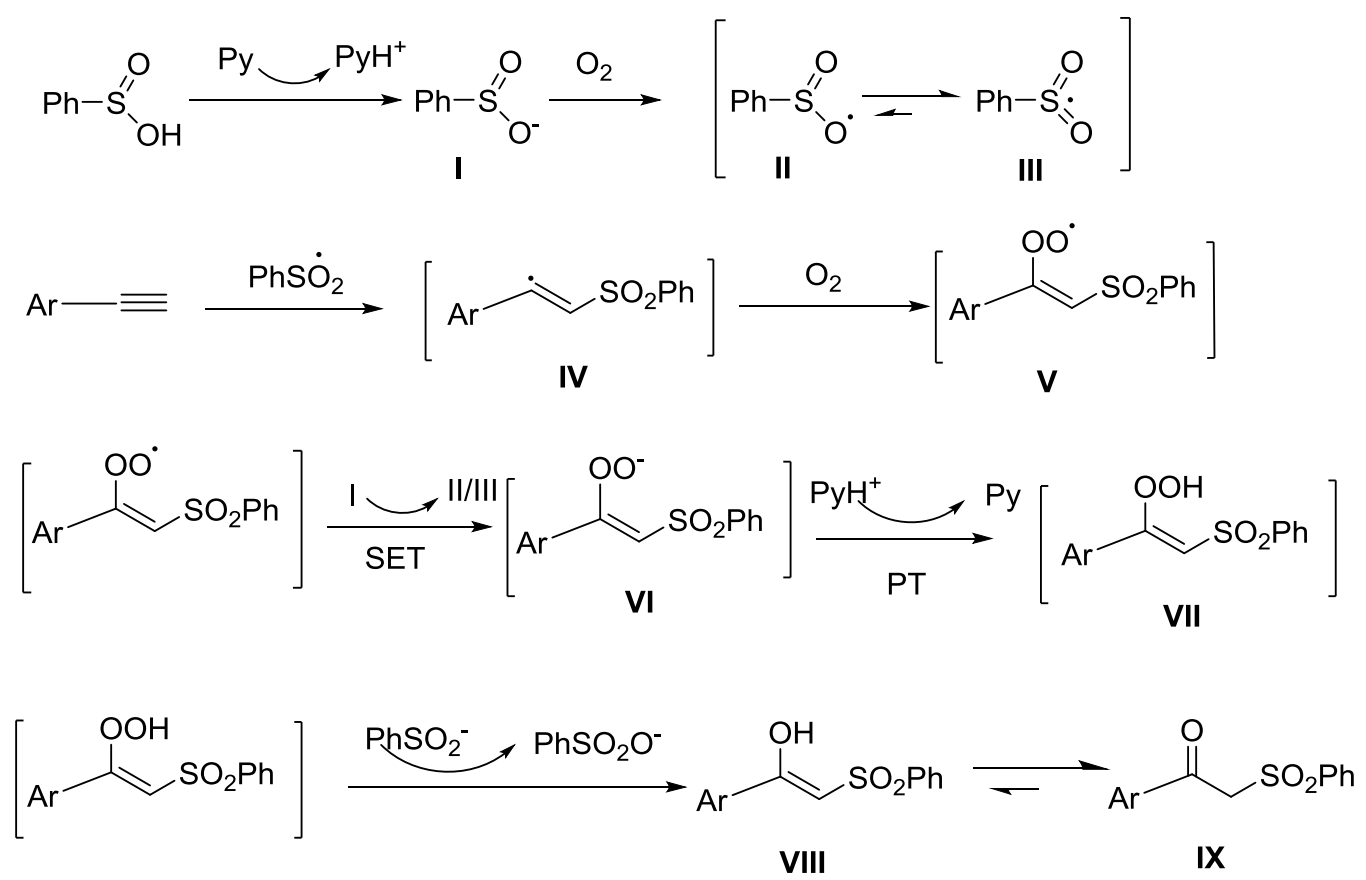

Scheme 16. Mechanism of synthesis of aryl ( $\beta$-keto)sulfone via pyridine catalyzed dioxygen triggered oxidative radical reaction

The mechanism of this reaction can be explained as depicted in Scheme 16 which involves generation of the more stable tosyl radical III from the interaction of $p$-toluene sulfinic acid with pyridine followed by oxygen molecule. Interaction of the aryl acetylene with $p$-toluene sulfonyl radical followed by molecular oxygen gives peroxy type radical V. Single electron transfer and protonation gives $\beta$-peroxyvinyl sulfone intermediate VII. Subsequent oxygen abstraction and tautomerization afford $\beta$-keto sulfone IX.

\subsubsection{Selected reactions of $\beta$-keto sulfones}

The $\beta$-keto sulfones have two reactive centers which are active methylene group and carbonyl group. So, the reactivity $\beta$-keto sulfones can be described by the reactions of each of these two groups separately or the interplay of these reactive groups. As the position of the 
methylene group is in between two electron withdrawing groups which are carbonyl group and sulfonyl moiety, the proton of the methylene group is significantly acidic $\left(p \mathrm{~K}_{\mathrm{a}}=9-10\right){ }^{60}$

$\beta$-Keto sulfones undergoes a base promoted Knoevenagel type of reaction to afford sulfonyl substituted vinyl ketone derivatives as shown in Scheme 17. Thus treatment of benzyl sulfonyl ethan-2-one A with aryl aldehydes gives (E)-a-benzylsulfonyl chalcone derivatives $\mathbf{B}$ which possess antiproliferative activity. ${ }^{61}$

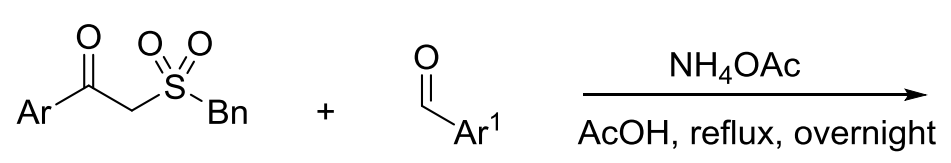

A

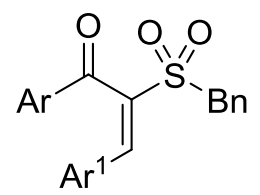

B

Scheme 17. Knoevengal condensation of $\beta$-keto sulfones to afford ( $E$ )- $\alpha$-benzylsulfonyl chalcone derivatives

Palladium catalyzed allylic alkylation of phenylsulfonyl acetophenone A with either methyl phenyl acetylene $\mathbf{B},{ }^{62}$ or phenyl allene $\mathbf{C},{ }^{63}$ or cinnamic alcohol $\mathbf{D},{ }^{64,65}$ gives corresponding highly $E$-stereoselective $\alpha$-monoallylated product $\mathbf{E}$ as depicted in Scheme 18 with excellent yield.
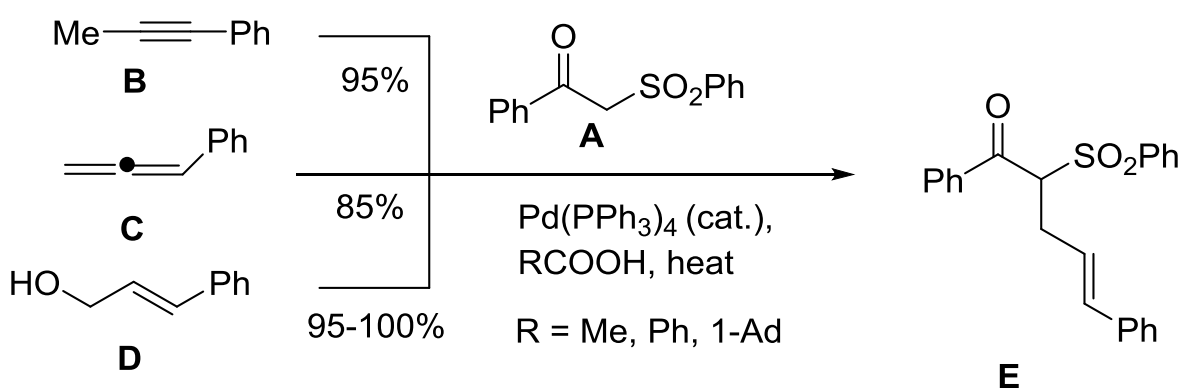

Scheme 18. Pd-catalyzed allylic alkylation of phenylsulfonyl acetophenone for the synthesis of $E$-stereoselective $\alpha$-monoallylated $\beta$-keto sulfone

The $\alpha$-arylated analogue of $\beta$-keto sulfone have been synthesized via direct arylation reaction as demonstrated in Scheme 19. Thus, palladium catalyzed reaction of phenylsulfonyl 
acetophenone A with aryl bromide in the presence of $\mathrm{NaH}$ affords $\alpha$-arylated product $\mathbf{B}$ with moderate yield. ${ }^{66}$

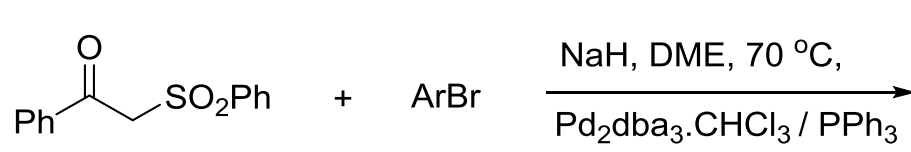

A

$$
\mathrm{Ar}=p-\mathrm{CF}_{3}-\mathrm{C}_{6} \mathrm{H}_{4}
$$<smiles>O=C(c1ccccc1)C([Al])S(=O)(=O)c1ccccc1</smiles>

B

Scheme 19. Pd-catalyzed arylation at $\alpha$-position of phenylsulfonyl acetophenone

Treatment of 1-(4-methylsulfonyl)propane-2-ones A with 1-alkylpyrrolidine-2-thione methyl iodide salts in the presence of triethylamine; condensation product $\beta$-sulfonyl substituted enamines B are obtained as single $E$ isomer as depicted in Scheme $20 .{ }^{67}$<smiles>CC(=O)CS(=O)(=O)c1ccc(C)cc1</smiles>

A<smiles>[R]N1CCCC1=S</smiles>

$\mathrm{R}=$ Alkyl, Alkyl ester

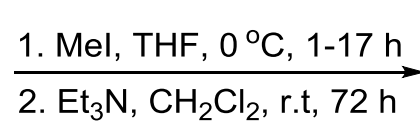<smiles>CC(=O)C(=C1CCCN1)S(=O)(=O)c1ccc(C)cc1</smiles>

B

Scheme 20. Alkylation of $\beta$-keto sulfones with 1-alkylpyrrolidine-2-thione methyl iodide salts for the synthesis of $\beta$-sulfonyl substituted enamines

When of $\beta$-keto sulfones $\mathbf{A}$ are treated with $N$-[1-acetoxy-2,22-trichloro)ethyl] urea in the sodium hydride, trichlorosubstituted oxoalkyl ureas B are obtained. Subsequent treatment of these oxoalkyl urea products $\mathbf{B}$ with para-toluenesulfonic acid give arylsulfonyl-substituted tetrahydropyrimidin-2(1H)-ones $\mathrm{C}$ as shown in Scheme $21 .^{68}$ 
<smiles>[R]C(=O)CS(=O)(=O)[18F]</smiles>

A

$\mathrm{R}=\mathrm{Me}, \mathrm{Ph} ;$

$\mathrm{Ar}=\mathrm{Ph}, p-\mathrm{Tol}$

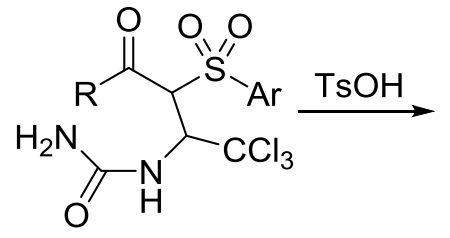

B<smiles>[R]C1=C([Se]O[Na])C(C([Si])(Cl)Cl)NC(=O)N1</smiles>

C

Scheme 21. Alkylation of $\beta$-keto sulfones with $N$-[1-acetoxy-2,22-trichloro)ethyl] urea to afford arylsulfonyl-substituted tetrahydropyrimidin-2(1H)-ones

Treatment of nonaflyl acetone A with $\beta$-chloroethyl isocyanate in the presence of triethyl amine as base affords corresponding 1,3-oxazolidine $\mathbf{B}$ as shown in Scheme 22. In this reaction triethyl amine deprotonates at the $\alpha$-carbon of $\mathbf{A}$ and subsequent electrophilic attacks at the isocyanate carbon followed by cyclization and tautomerization gives 1,3-oxazolidine product B. ${ }^{69}$

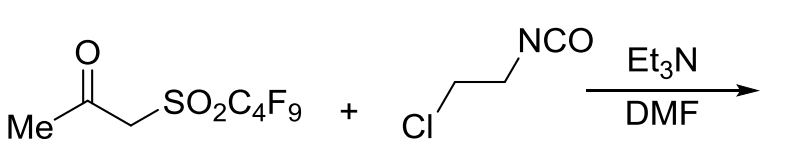

A<smiles>CC(=O)C(C(=O)OC(F)(F)F)=C1NCCO1</smiles>

B

Scheme 22. Synthesis of 1,3-oxazolidine by the reaction of nonaflyl acetone with $\beta$ chloroethyl isocyanate

$\alpha$-Diazo $\beta$-keto sulfones $\mathbf{B}$ are synthesized by treating correspoding $\beta$-keto sulfones $\mathbf{A}$ with different sources of diazo group such asTsN $3,{ }^{70} \mathrm{TfN}_{3},{ }^{71} \mathrm{NfN}_{3},{ }^{72} \mathrm{I}\left(\mathrm{CF}_{2}\right)_{2} \mathrm{O}\left(\mathrm{CF}_{2}\right)_{2} \mathrm{SO}_{2} \mathrm{~N}_{3},{ }^{73}$ and ionic-liquid supported sulfonyl azide as depicted in Scheme 23. ${ }^{74}$ 


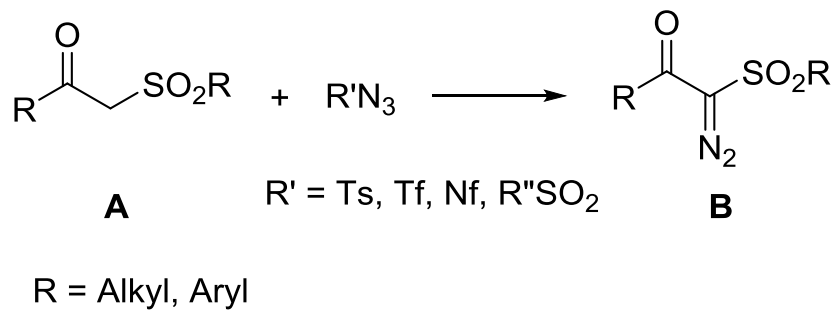

Scheme 23. Synthesis of $\alpha$-diazo $\beta$-keto sulfones

Treatment of $p$-toluene sulfonyl acetophenone $\mathbf{A}$ with potassium halide and hydrogen peroxide in acetic acid gives $\alpha$-monohalogenated product $\mathbf{B}$ with high yield where potassium halides are the source of halogen atoms. Subsequent treatment of these monohalogenated products $\mathbf{B}$ with $\mathrm{SO}_{2} \mathrm{Cl}_{2}$ or $\mathrm{Br}_{2}$ in the presence of triethylamine give $\alpha, \alpha$-dihalogenated products $\mathrm{C}$ as demonstrated in Scheme $24 .^{75}$

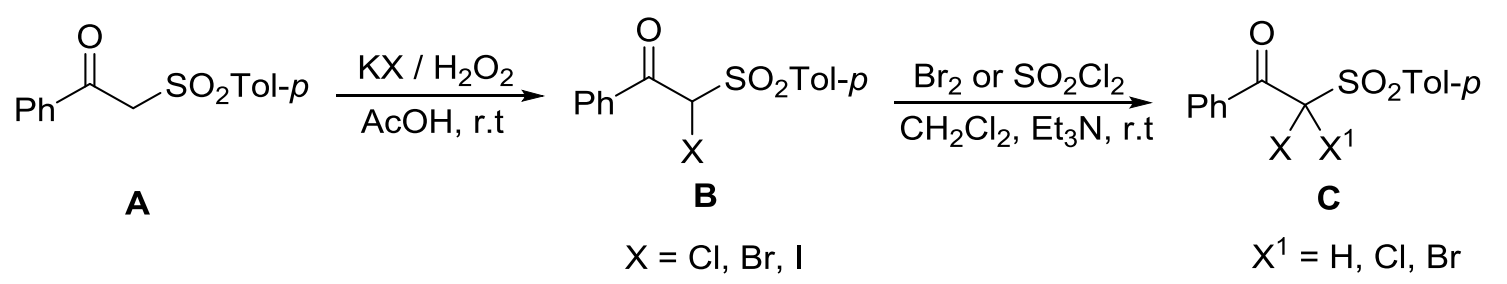

Scheme 24. Chemoselective $\alpha$-mono and di-halogenation at the $\alpha$-carbon of $\beta$-keto sulfones

The $\alpha$-iodo $\beta$-keto sulfone $\mathbf{B}$ can be prepared efficiently by treating corresponding $\beta$-keto sulfones A either with iodine monochloride in acetic acid ${ }^{76}$ or molecular iodine in aqueous acidic hydrogen peroxide as shown in Scehme $25 .{ }^{.7}$

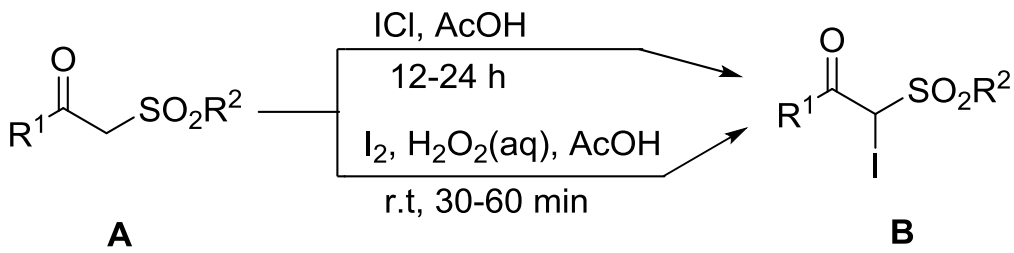

$$
\mathrm{R}^{1}, \mathrm{R}^{2}=\mathrm{Alk}, \mathrm{Ar}
$$

Scheme 25. Synthesis of $\alpha$-Iodo $\beta$-keto sulfone using iodine monochloride or iodine 
Treatment of $\beta$-keto sulfones A with [hydroxyl(tosyloxy)iodo] benzene affords to $\alpha$ tosyloxy substituted $\beta$-keto sulfones B from very good to excellent yields as depicted in Scheme $26 .^{78}$ No solvent is required in this reaction.

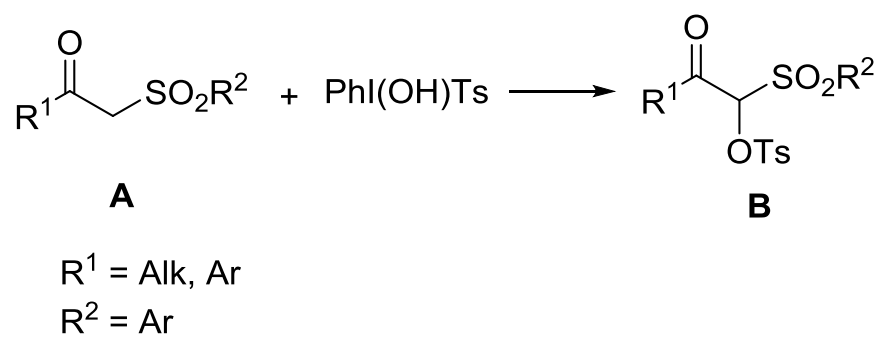

Scheme 26. Synthesis of $\alpha$-tosyloxy $\beta$-keto sulfone via solvent free reaction

Treatment of $\beta$-keto sulfone $\mathbf{A}$ with formalin, and thiol or thiophenol in water gives Mannich type thiesters B in good to excellent yield (Scheme 27) ${ }^{79}$ In this reaction first $\beta$-keto sulfones interact with formaldehyde to give $\alpha$-methylene $\beta$-keto sulfones through a Knoevangal type reaction. Later the intermediate is attacked by thiol and affords the product via a Michael addition reaction.
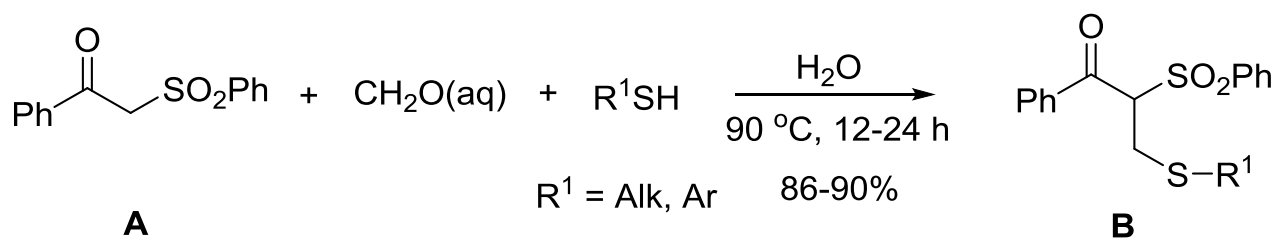

Scheme 27. Incorporation of methylthiol moieties at $\alpha$-position of $\beta$-keto sulfones by Mannich type reaction

Treatment of methyl sulfonyl A acetone with triflic acid or methanesulfonic acid affords $(E)$ $\beta$-ferrocenyl- $\alpha, \beta$ unsaturated sulfone B via Friedel-Crafts type reaction as depicted in Scheme $28{ }^{80}$ 


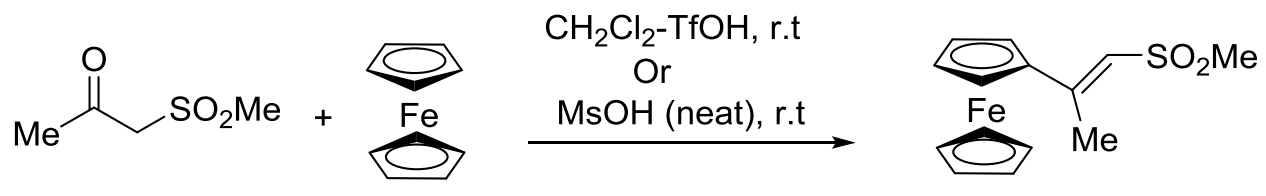

A

B

Scheme 28. Synthesis of $(E) \beta$-ferrocenyl- $\alpha, \beta$-unsaturated sulfone via Friedel-Crafts type reaction

Treatment $\beta$-keto sulfone $\mathbf{A}$ with hydroxyl amine under reflux in ethanol afford $\beta$-hydroxy sulfone $\mathbf{B}$ as demonstrated in Scheme $29 .{ }^{81}$

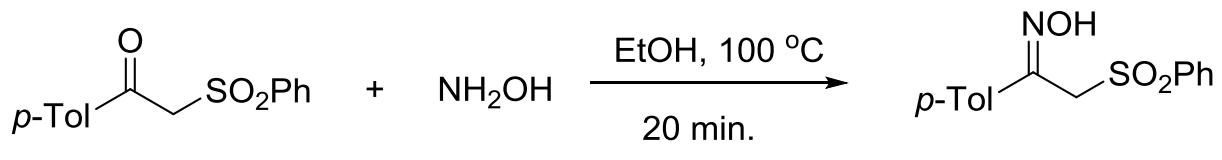

A

B

Corey-Bakshi-Shibata (CBS) catalyzed asymmetric reduction of $\beta$-keto sulfones $\mathbf{A}$ with $\mathrm{N}$-ethyl-N-isopropylaniline-borane complex give optically active $\beta$-hydroxy sulfones with excellent enatiometric excess (ee) as shown in Scheme $30 .{ }^{82}$

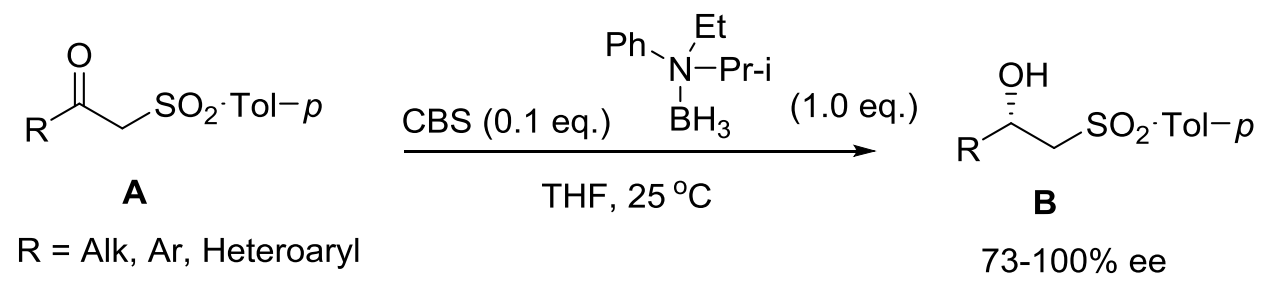

Scheme 29. Asymmetric borane reduction of $\beta$-keto sulfones for convertion into $\beta$ hydroxy sulfones

When $\beta$-keto sulfone $\mathbf{A}$ is treated with aryl azide in the presence of sodium methoxide, Naryl substituted 1H-1,2,3-trizoles $\mathbf{B}$ are afforded from good to excellent yield via base catalyzed Dimroth reaction (Scheme 31). ${ }^{83}$ 


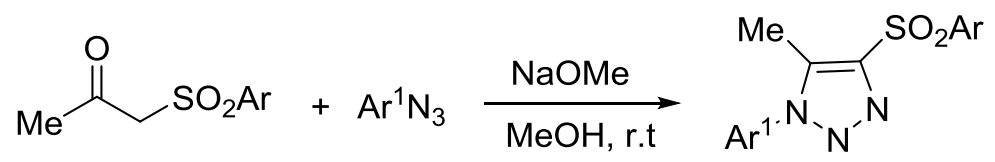

A

B

Scheme 30. Synthesis of $N$-substituted triazoles from $\beta$-keto sulfones via base catalyzed Dimroth reaction

The reaction of $\beta$-keto sulfones $\mathbf{A}$ with arylazide in the presence of pyrrolidine as ograno catalyst affords 4-sulfonyl 1,2,3-triazoles $\mathbf{B}$ from good to excellent yields as depicted in Scheme $32 .{ }^{84}$ In this reaction pyrrolidine forms enamine with the $\beta$-keto moiety which played the key role for the success of this reaction.

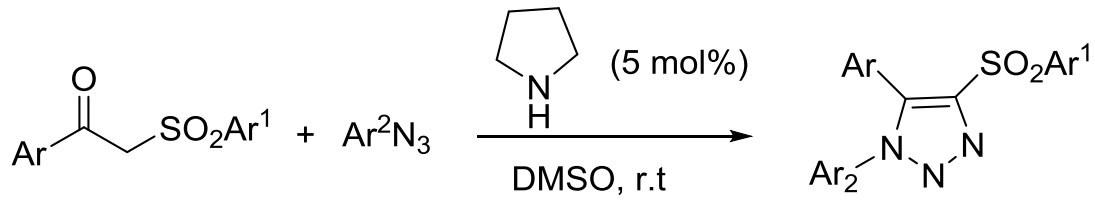

A

B

Scheme 31. Synthesis of N-substituted triazoles from $\beta$-keto sulfones using pyrolidine as organo catalyst

\subsubsection{Biological activity}

The $\beta$-keto sulfone contains biologically important sulfonyl moiety which captivates attention of the pharmaceutical chemist to investigates their pharmacological properties. Research shows that certain types of ( $\beta$-keto) sulfones are potent and selective inhibitors of $11 \beta$-hydroxysteroiddehydrogenase type $1(11 \beta$-HSD 1$) .{ }^{85}$ In addition the ( $\beta$-keto) sulfones are active against pernicious microorganism ${ }^{86}$ and cyclic ( $\beta$-keto) sulfones also exhibit fungicidal activities. $^{87}$ 


\subsection{Short overview of prodrugs}

Prodrugs are the compounds which are metabolized after entering into the cell of the body to act as drugs. ${ }^{88}$ The chemical modification of a pharmacologically active agent that must undergo transformation to release the active drug after entering into the cell is a well known and convenient strategy to enhance the physiochemical, biopharmaceutical or pharmacokinetic properties of pharmacologically potent compounds. ${ }^{89-92}$ By designing and synthesizing prodrugs different parameters such as poor cell permeability, low aqueous solubility, chemical instability, insuffient oral absorption, rapid pre-systemic metabolism etc. can be overcome. ${ }^{92,93}$ In short, prodrugs enhance the absorbtion, distribution, metabolization, and excretion (ADME) properties of drugs. ${ }^{94}$ Currently 5-7\% of approved drugs can be sorted out as prodrugs and in 2001-02 about $15 \%$ of new drugs were approved as prodrugs. ${ }^{95}$

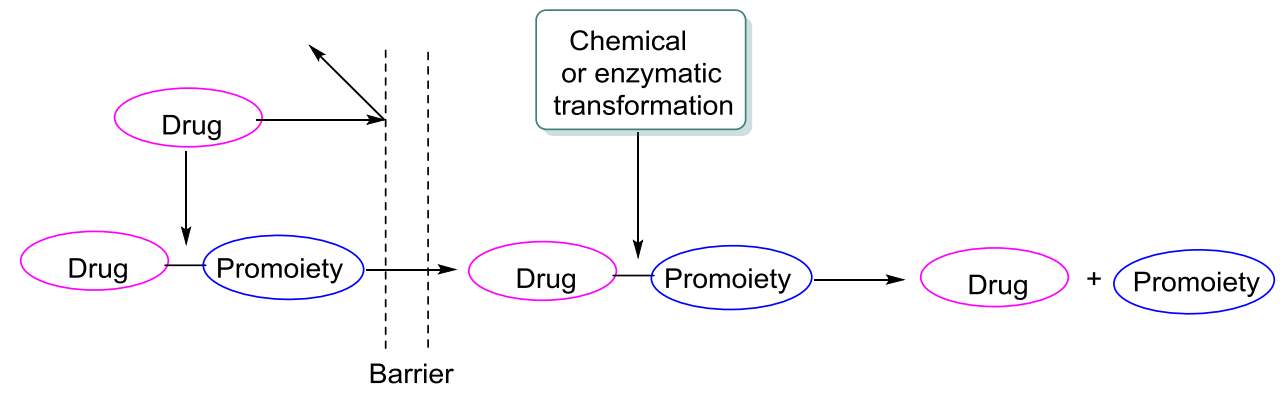

Scheme 32. General representation of prodrug concept ${ }^{96}$

Some common functional groups which are convenient to design prodrugs are carboxylic, hydroxyl, amine, phosphate/phosphonate, and carbonyl group. These groups can be converted into esters, carbonates, carbamates, amides, phosphates, and oximes to obtain the corresponding prodrugs. ${ }^{96}$ In addition thiols can be converted into thioethers, ${ }^{97}$ or thioesters ${ }^{98}$ whereas amine can be converted into imines, ${ }^{99,100}$ and N-Mannich bases ${ }^{101}$ as the prodrug synthetic approach. 


\subsubsection{Prodrug of nucleoside analogues}

One of the convenient and effective methods used to synthesize nucleoside prodrugs is the incorporation of different liphophilic groups either at the base moieties or at the sugar moieties via acylation or an alkylation reaction to improve cell permeability to the drug.

Gemcitabine is a well-known anticancer drug which is widely used to treat breast cancer, pancreatic cancer, bladder cancer, lung cancer, and others. ${ }^{102}$ However, research shows that significant amount of gemcitabine converts into corresponding uridine analogues in the cell as a result of the deamination by the cytidine deaminase enzyme. ${ }^{103} 4-\mathrm{N}$-Alkonylation of gemcitabine can significantly reduce the extent of deamination process and exhibit better efficiency. ${ }^{104}$ On the basis of the finding 4-N acylated produg of gemcitabine LY2334737 has been developed (Figure 4). ${ }^{105,106}$

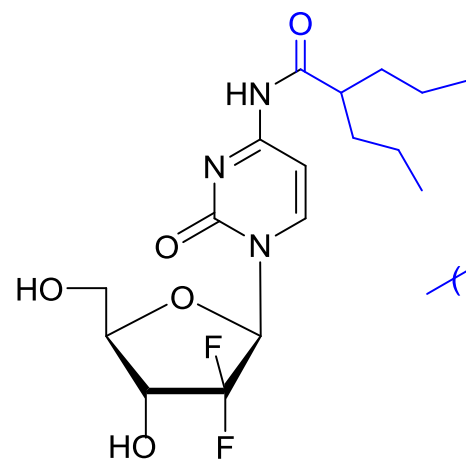

A

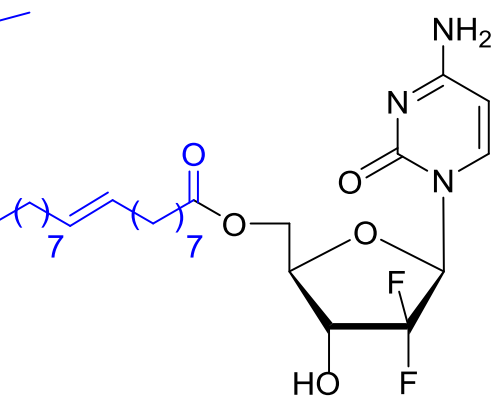

B

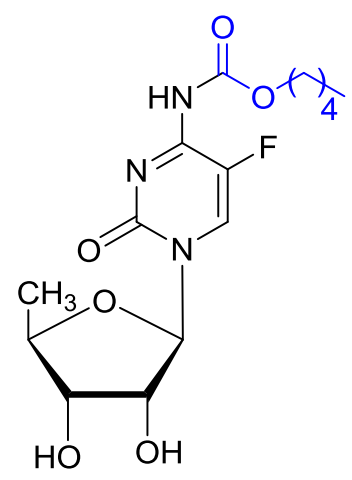

C

Figure 4. 5'-Acylated CP-4126 (A), 4-N-acylated prodrug LY2334737 (B) of Gemcitabine and Capecitabine $(\mathrm{C})$ prodrug of 5-fluorouracil

The 5'-acylated gemcitabine analogues which is also known as CP-4126 is a well-known prodrug (Figure 4). ${ }^{107}$ The lipophilic alkyl long chain enhances the cell permeability of the original drug gemcitabine. After entering into the cell the prodrug converts into original drug 
gemcitabine by the esterase enzyme. ${ }^{108}$ Capecitabine is a prodrug of 5-fluorouracil which is widely used for the treatment of breast cancer, gastric cancer, and colorectal cancer. ${ }^{109,110}$

Mericitabine which is also known as RG7128 is an antiviral prodrug of PSI-6130 and used for the treatment of hepatitis $\mathrm{C}$ virus infected patients as a combination therapy with other antiviral drugs (Figure 5). ${ }^{11}$ The drug acts by inhibiting NS5B RNA polymerase, a primary transcript RNA. ${ }^{17}$

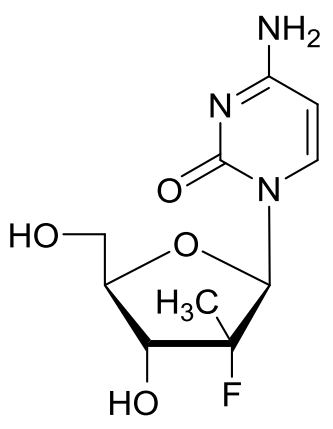

PSI 6130

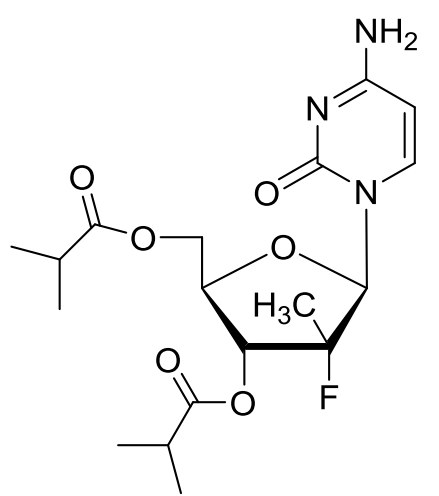

RG7128

Figure 5. PSI 6130 and its prodrug mericitabine (RG7128) 


\section{RESEARCH OBJECTIVES}

My first research objective was the synthesis of 5-(1-halo-2-tosylvinyl)pyrimidine nucleosides (A). Recently, ( $\beta$-halo)vinyl sulfone analogues gained considerable amount of attention because of their reactivity and important biological activities. As ( $\beta$-halo)vinyl sulfones possess reactive halovinyl sulfonyl moiety along with electronegative halogen atom at the $\beta$-position, I thought it would be interesting to synthesize nucleoside analogues modified with ( $\beta$-halo)vinyl sulfone and exploring their reactivities and biological properties. To get access to 5-( $\beta$-chloro/bromo)vinyl sulfones (A) I explored transition-metal catalyzed halovinylsulfonylation of 5-alkynyl uracil and cytosine nucleosides with $p$-toluenesulfonyl hydrazine in the presence of tert-butyl hydrogen peroxide. The synthesis of 5-( $\beta$-iodo)vinyl sulfones (A) would be attempted via $N$-iodosuccinamide mediated halosulfonylation reactions of the 5-alkynyl uracil and cytosine nucleosides with sodium salt of sulfinic acid.

The typical reaction of the unsubstituted vinyl sulfone with nucleophiles occurs via the Michael addition reactions. As ( $\beta$-halo)vinyl sulfone possesses halogen atom at the $\beta$-position, it would be fascinating to explore these type of reactions with the ( $\beta$-halo)vinyl sulfone. So, I was planning to explore reactivity of the novel ( $\beta$-halo)vinyl sulfones with different nucleophiles i.e., thiolates, amines, amino acid to observe whether it underwent a Michael addition or conjugated addition-elimination reaction to give 5-(1-substituted-2tosylvinyl)pyrimidine nucleosides (B). I was also eager to investigate the feasibility of bioconjugation of these novel halovinyl sulfone analogues by reacting them with biomolecules such as tripeptide L-glutathione. The ( $\beta$-chloro/bromo/iodo)vinyl sulfones would be prepared to study the mechanism of the conjugated addition-elimination reactions employing kinetic and synthetic approaches. Since ( $\beta$-halo)vinyl sulfones as well as their 
products of the addition-elimination reactions with nucleophiles are trisubstituted alkenes, the stereochemistry at the double bond of these novel pyrimidine-based 5-( $\beta$-halo)vinyl sulfones will be established using advanced 2D-NMR techniques and single X-ray crystallographic method. Moreover, since 5-modified pyrimidine nucleosides have been demonstrated to possess antiviral and antiproliferative properties, I would explore the biological properties of these novel ( $\beta$-halo)vinyl sulfone in various viral (e.g. herplex simplex virus, human cytomegalovirus, parafluenza virus) and cancer (e.g. murine leukemia, human T-lymphocyte, human cervix carcinoma) cells. I was also planning to investigate if changing the polarity of the ( $\beta$-halo)vinyl sulfone analogues by incorporating different liphophilic alkyl groups (as an carboxylic esters) at the sugar moiety would increase their antproliferative properties.

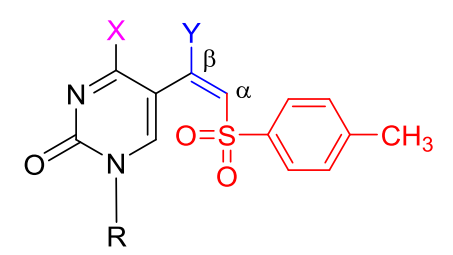

A

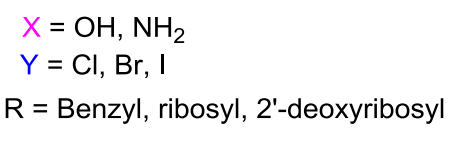

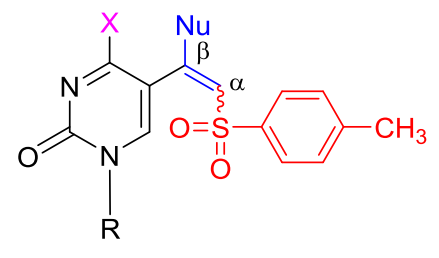

B

$\mathrm{X}=\mathrm{OH}, \mathrm{NH}_{2}$

$\mathrm{Nu}=$ Nucleophiles

$\mathrm{R}=$ Benzyl, ribosyl, 2'-deoxyribosyl

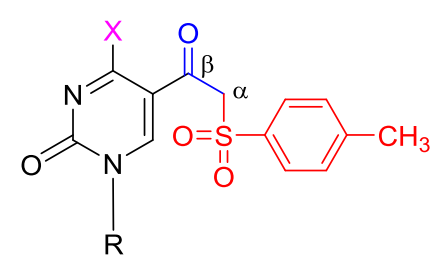

C

$\mathrm{X}=\mathrm{OH}, \mathrm{NH}_{2}$

$\mathrm{R}=$ Benzyl, ribosyl, 2'-deoxyribosyl

Figure 6. General structure of 5-modified pyrimidine nucleoside analogues

My second research objective was the synthesis of novel 5-( $\beta$-keto)sulfone analogues of pyrimidine nucleoside $(\mathbf{C})$ and exploring their reactivity at the $\alpha$-carbon of these sulfones. Synthesis of these novel ( $\beta$-keto)sulfone analogues would be attempted by di-oxygen triggered oxidative radical reaction of the 5-ethynyl pyrimidine nucleosides with $p$ toluenesulfinic acid in the presence of pyridine and oxygen. Alternatively the ( $\beta$-halo)vinyl sulfone analogues would be converted into corresponding $\beta$-keto sulfone analogues by applying one-pot synthetic protocol which would involve conversion of the ( $\beta$-halo)vinyl 
sulfone into the corresponding ( $\beta$-amino)vinyl sulfone followed by acid hydrolysis of the latter intermediate into ( $\beta$-keto)sulfone will be also developed. Since the $\alpha$-carbon of 5-( $\beta$ keto)sulfones $\mathbf{C}$ possess acidic protons, I would explore further modification of these novel probes. My ultimate goal was to verify the feasibility of the reactivity at the $\alpha$-carbon of $\beta$ keto sulfone analogues with different electrophiles and possibly nucleophiles and finally demonstrate the feasibility of the bioconjugation of the 5-( $\beta$-keto)sulfone modified DNA with proteins.

My third and final research objective was to incorporate the novel 5-( $\beta$-chloro)vinyl and 5( $\beta$-keto)sulfone-2'-deoxyuridine triphosphatesinto DNA so that study of DNA-proteins interactions under the physiological conditions could be explored. Thus, Yoshikawa phosphorylation of 5 -( $\beta$-chloro)vinyl or 5 -( $\beta$-keto) sulfones followed by coupling of the resulting 5'-O-monophosphate with ammonium pyrophosphate should afford the corresponding 5'-O-triphosphates. These novel 5-modified 2'-deoxyuridine nucleotides will be attempted to be incorporated into DNA fragments by polymerase-catalyzed reaction. If successful, I was planning to investigate bioconjugation of these active probes with tripeptide L-glutathione. My final goal was to explore bioconjugation of such modified DNA with transcription factors such as c-Myc protein which is rich in nucleophilic thiol (cysteine) residues. If successful, further study might uncover critical information of the role of this protein in gene expression and DNA replication. 


\section{RESULTS AND DISCUSSIONS}

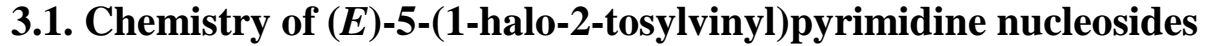

\subsubsection{Synthesis of $(E)-5$-(1-chloro/bromo/iodo-2-tosylvinyl)uracil nucleosides}

General approaches for the synthesis of targeted 5-modified pyrimidine nucleosides involve investigation of halosulfonylation reactions with the nucleoside-derived terminal alkynes. Thus, in the first step a reactive acetylene group was incorporated at C5-position of the uracil nucleosides which involved highly efficient Sonogashira coupling of 5-iodo uracil nucleoside analogues following Robin's procedure ${ }^{12}$ followed by sequential deprotection of the protecting groups (Scheme 34).

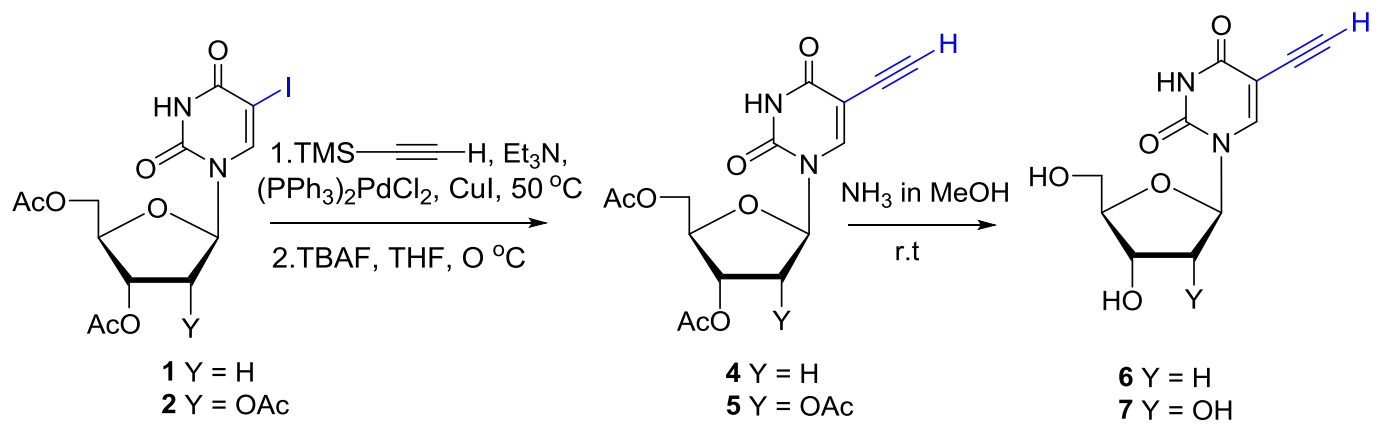

Scheme 33. Incorporation of reactive acetylene group at 5 position of uracil nucleosides

Iron (III) chloride mediated and TBHP promoted regio and stereoselective chlorosulfonylation reaction of protected 5-ethynyluridine 5 gave a single $E$ isomer of 2',3',5'tri-O-acetyl-5-(1-chloro-2-tosylvinyl)uridine (8) with 68\% yield. Analogous treatment of protected 2'-deoxyuridine $\mathbf{4}$ afforded 3',5'-di- $O$-acetyl-5-(1-chloro-2-tosylvinyl)-2'deoxyuridine (9) with $76 \%$ yield. Treatment of 5-ethynyluridine 7 with $p$-toluenesulfonyl hydrazide and iron(III) chloride in the presence of tertiary butyl hydrogenperoxide gave (E)-5(1-chloro-2-tosylvinyl)uridine $\mathbf{1 0}$ with 59\% yield. Analogous treatment of $\mathbf{6}$ in the same 
condition gave (E)-5-(1-chloro-2-tosylvinyl)-2'-deoxyuridine (9) with 90\% yield (Scheme $35) .{ }^{90}$
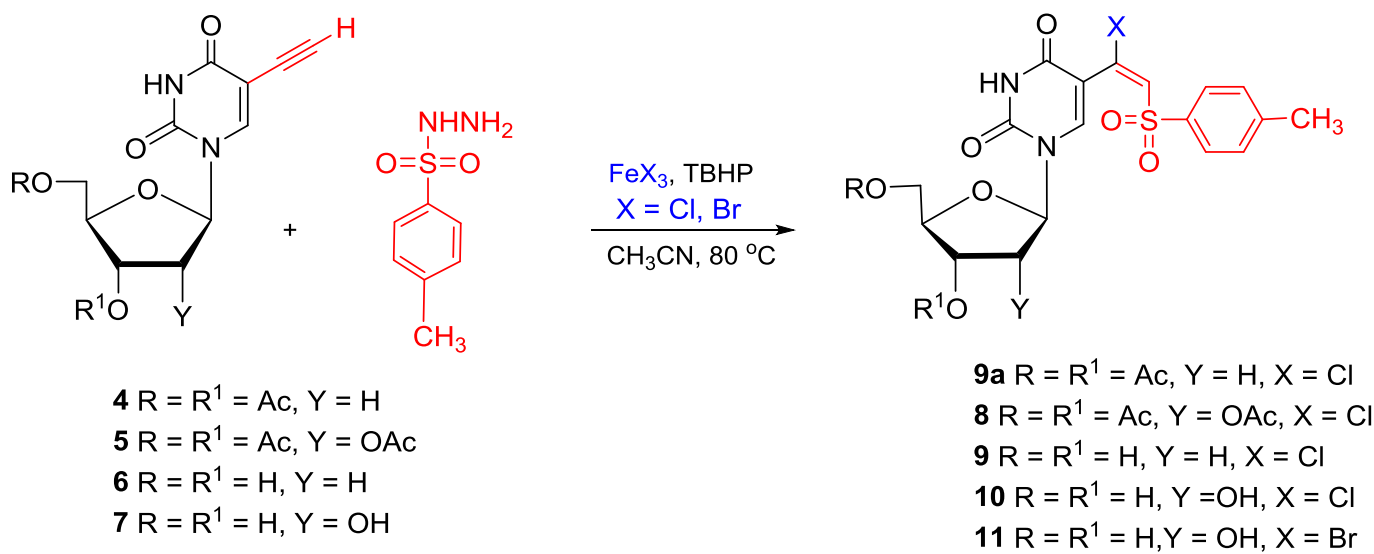

Scheme 34. Synthesis of (E)-5-(1-chloro/bromo-2-tosylvinyl)uracil nucleosides via iron catalyzed halosulfonylation reaction

Treatment of 5-ethynyluridine 7 with $p$-toluenesulfonyl hydrazide and iron(III) bromide in the presence of tertiary butyl hydrogenperoxide gave (E)-5-(1-bromo-2-tosylvinyl)uridine 11 with $41 \%$ yield. The structure of 8-11 was determined by using NMR techniques and the $E$ stereochemistry was established based on literature report and analysis from X-ray crystallography as described in Section 3.1.3.2.

The 5-(1-iodo-2-tosylvinyl)uracil nucleoside analogues were synthesized by NIS promoted halosulfonylation reaction with 5-ethynyl uracil nucleosides and sodium salt of $p$ toluenesulfinic acid as depicted in Scheme 36. 
<smiles>C#Cc1cn(C2OC3OC(C(O)C3O)C2O)c(=O)[nH]c1=O</smiles>

7<smiles>Cc1ccc(S(=O)(=O)[O-])cc1</smiles>

$\underset{\mathrm{THF}, 64^{\circ} \mathrm{C}}{\stackrel{\mathrm{NIS}}{\longrightarrow}}$

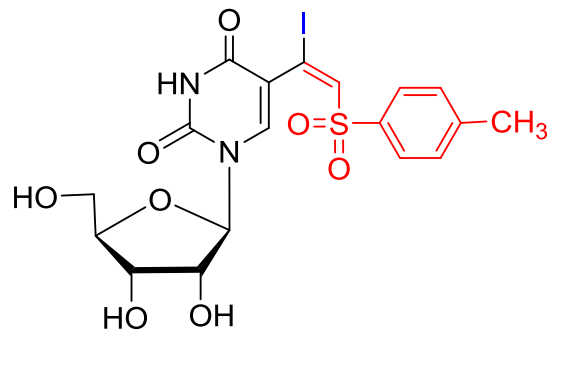

12

Scheme 35. Synthesis of (E)-5-(1-iodo-2-tosylvinyl)uracil nucleosides via NIS promoted halosulfonylation reaction

Thus treatment of 5-ethynyluridine 7 with sodium salt of $p$-toluenesulfinic acid gave $(E)$ 5-(1-iodo-2-tosylvinyl)uridine 12 with $42 \%$ yield. The structure of the compound was established by the applying different NMR techniques and mass was determined by using high resolution mass spectrometry. In ${ }^{1} \mathrm{H}$ NMR 12 has vinylic proton peak at $7.72 \mathrm{ppm}$ while the vinylic carbon peaks appeared at 105.5 ppm.s

\subsubsection{Synthesis of $(E)-5$-(1-chloro/bromo/iodo-2-tosylvinyl)cytosine nucleosides}

The $\beta$-halo sulfonylation reaction was also extended to cytosine nucleoside. An acetylene functional group at the C5-position offers a convenient way to synthesize 5-( $\beta$-chlorovinyl) sulfone of cytidine or 2'-deoxycytidine nucleosides. The acetylene moiety was efficiently incorporated at C5- position of these nucleosides via an acetyl protection at the sugar moiety, iodination at 5 position, Sonogashira coupling, silyl deprotection (Scheme 37). ${ }^{113}$

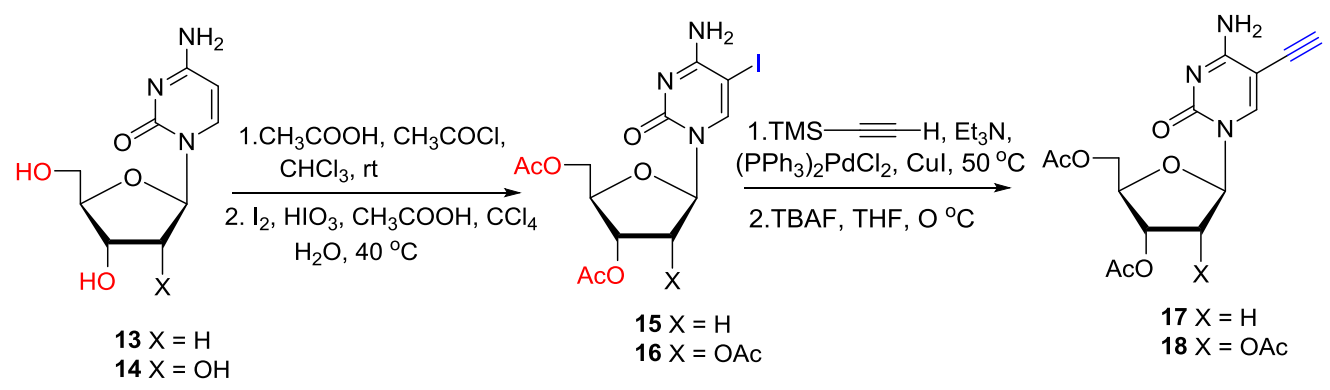

Scheme 36. Synthesis of acetyl protected 5-ethynylcytidine and 2'-deoxycytidine analogues 
Thus, treatment of 5 ethynyl analogue $\mathbf{1 7}$ with tosyl hydrazide in the presence of iron (III) chloride and tertiary butyl hydrogen peroxide gave ( $\beta$-chloro)vinyl sulfone analogue 19 with 68\% yield. Analogous treatment of $\mathbf{1 8}$ with tosyl hydrazide in the similar reaction condition gave 20 with $60 \%$ yield (Scheme 38).
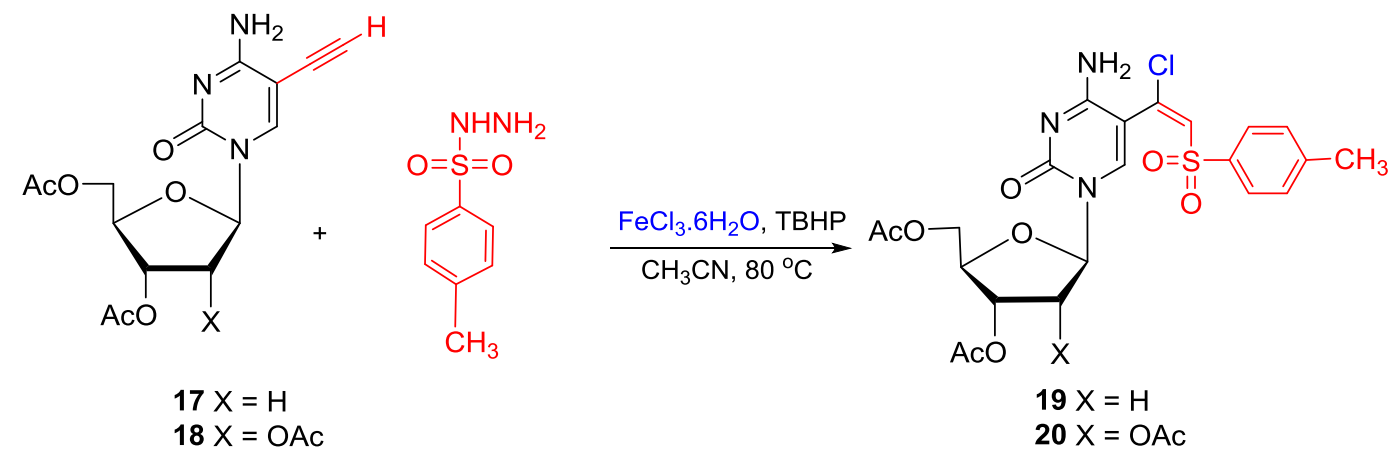

Scheme 37. Synthesis of $(E)-\beta$-chlorovinyl sulfone of protected cytidine and 2'deoxycytidine nucleosides

The structure of the compounds $\mathbf{1 9}$ and $\mathbf{2 0}$ were established by applying different NMR techniques such as ${ }^{1} \mathrm{H}, \mathrm{COSY}, \mathrm{HMQC}, \mathrm{DEPT}-135$, and ${ }^{13} \mathrm{C}$. The exact mass was determined by applying MALDI-TOF mass spectrometry. In proton NMR vinyl peak of $\mathbf{1 9}$ and $\mathbf{2 0}$ were obtained at 7.67 and $7.61 \mathrm{ppm}$ respectively. For both 19 and 20 methyl peak of tosyl group was observed at $2.40 \mathrm{ppm}$ while the aromatic peaks were observed in between 7.00 to 8.00 ppm. In ${ }^{13} \mathrm{C}$ NMR the vinyl peak of $\mathbf{1 9}$ and $\mathbf{2 0}$ was observed at 137.0, and $138.0 \mathrm{ppm}$ respectively while the methyl carbon peak of tosyl group were appeared at 21.0, and 21.8 ppm. Other aromatic peaks of the tosyl group were observed from 125 to $145 \mathrm{ppm}$. In addition a characteristics $\beta$-carbon peak was observed at 143.0 , and $139.5 \mathrm{ppm}$ respectively. In mass spectrum the characteristics isotopic pattern of one chlorine atom (peak intensity 3:1) was observed. Finally, the experimental mass value $[\mathrm{M}+\mathrm{H}]^{+} 526.1048$ and 583.1025 confirmed the successful synthesis of $\mathbf{1 9}$ and $\mathbf{2 0 .}$ 


\subsubsection{Addition-elimination reactions of (E)-5-(1-halo-2-tosylvinyl)pyrimidine nucleosides with nucleophiles}

The reactivity of the ( $\beta$-halo)vinyl sulfones of uracil and cytosine nucleosides was studied in details, and it was observed that they react efficiently with different nucleophiles such as amines, thiols, amino acid etc. through addition-elimination process to give the substituted products from moderate to good yield.
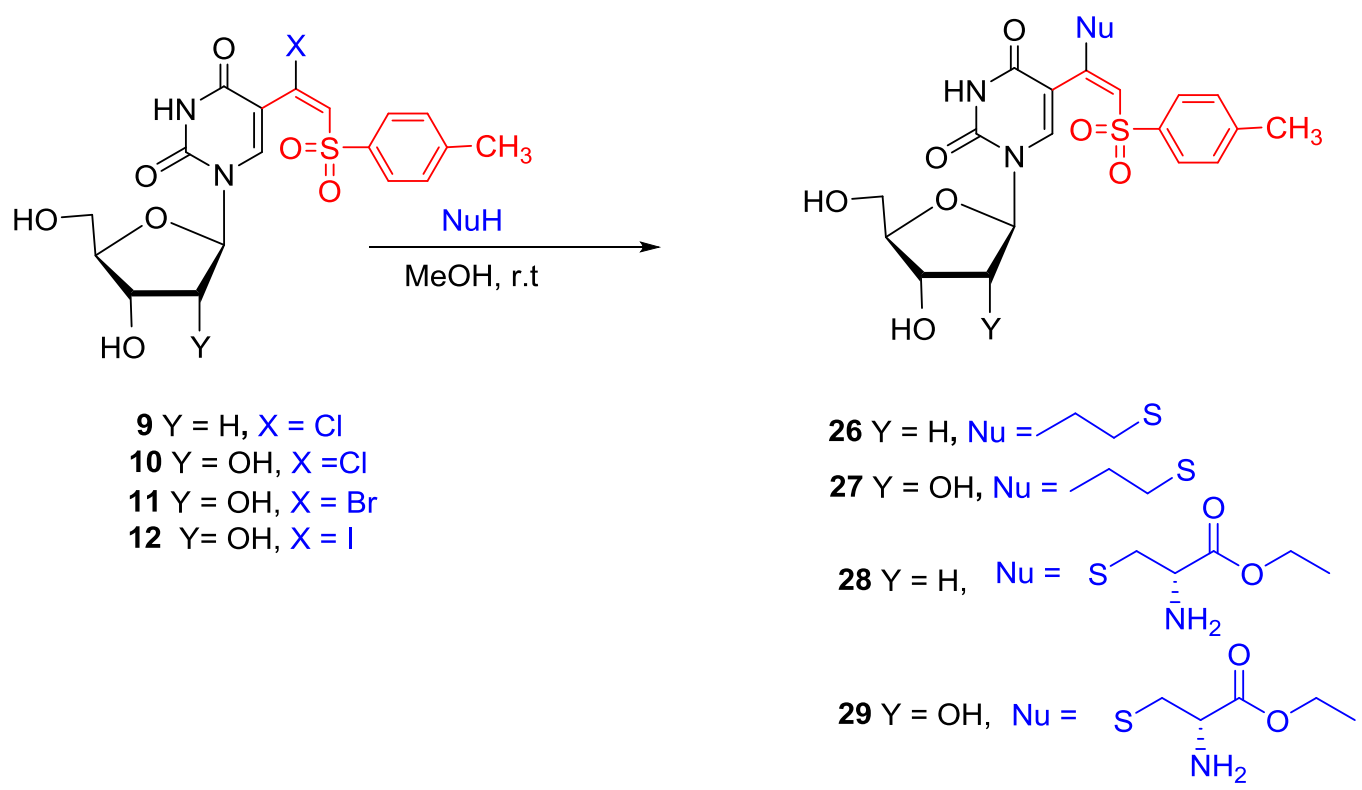

Scheme 38. Displacement of halogen atoms of uracil nucleosides by thiolates and amino acid to afford analogues with retention of configuration

Treatment of 9 with propane thiol in the presence of triethyl amine afforded propanethio substituted analogue $\mathbf{2 6}$ with $\mathbf{7 3 \%}$ yield. Analogous treatment of $\mathbf{1 0}$ with propane thiol in the presence of triethyl amine gave $\mathbf{2 7}$ with $75 \%$ yield (Scheme 39). Treatment of 9 with important amino acid derivative L-cysteine ethyl ester hydrogen chloride in the presence of triethyl amine afforded 28 as a 85/15 E/Z mixture and the yield was 60\%. Analogous treatment of $\mathbf{1 0}$ with amino acid derivative L-cysteine ethyl ester hydrogen chloride afforded 29 as a 85/15 E/Z mixture and the yield was 56\% (Scheme 39). 
The addition-elimination reaction of chlorovinyl sulfone analogue 9 was extended with well-known biomolecule and antioxidant L-glutathione. It is noteworithy to mention that glutathione is a tripeptide and thus can serve as a model compound to study bioconjugation with protein.

Thus, treatment of chlorovinyl sulfone analogue 9 with L-glutathione in the presence of triethylamine in mixed solvent (water and methanol) afforded glutathione incorporated product 30 with $56 \%$ yield (Scheme 40 ).

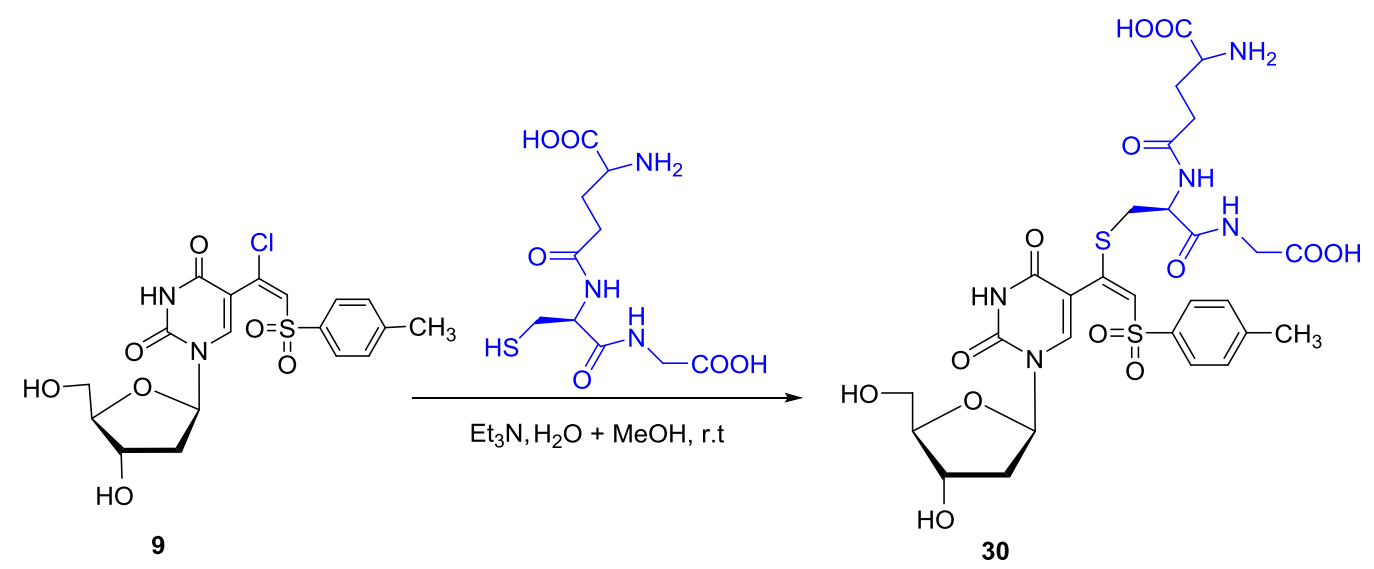

Scheme 39. Conjugation of 5- ( $\beta$-chloro)vinyl sulfone of 2'-deoxyuridine with Lglutathione via displacement reaction

The structure of the compound $\mathbf{3 0}$ was determined by applying different NMR techniques such as ${ }^{1} \mathrm{H}, \mathrm{COSY}, \mathrm{HMQC}$, DEPT-135, and ${ }^{13} \mathrm{C}$. The exact mass was confirmed by taking MALDI-TOF mass spectrometry. In proton NMR distinguished peaks of glutathione moiety were observer at the region from 2.0- $5.0 \mathrm{ppm}$. Each peaks was figured out from their correlation in COSY.

In carbon NMR four peaks of carbonyl carbon of the glutathione moiety were detected at 170.5, 174.0, 175.2, and $176.2 \mathrm{ppm}$. The remaining six carbon peaks of glutathione were 
observed at the region from 25.0 to $55.0 \mathrm{ppm}$. Finally, the experimental mass value of $\mathbf{3 0}$ verified the success of this reaction.

The success of the reaction is very encouraging because addition-elimination reaction of nucleophile with chlorovinyl sulfone probe can be performed in physiological condition and therefore can be explored for the bioconjugation of nucleic acid with protein. One of the potential candidate of such protein is c-Myc protein. Note that c-Myc is a DNA transcription regulatory protein which controls about $15 \%$ of gene expression ${ }^{114}$ and modified DNA- c-Myc protein interaction can significantly modulate the gene expression process and thus might play a crucial role in biological system.

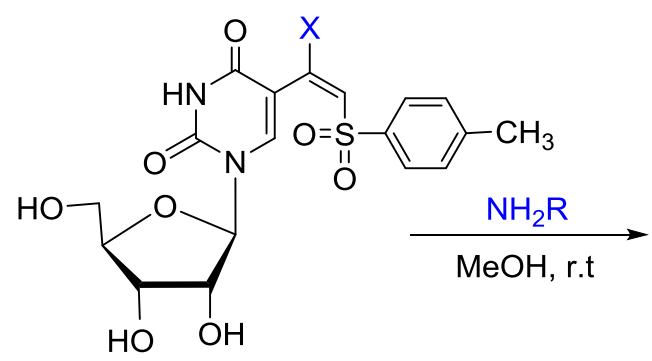

$$
\begin{aligned}
& 10 X=\mathrm{Cl} \\
& 11 X=\mathrm{Br} \\
& 12 \mathrm{X}=\mathrm{I}
\end{aligned}
$$

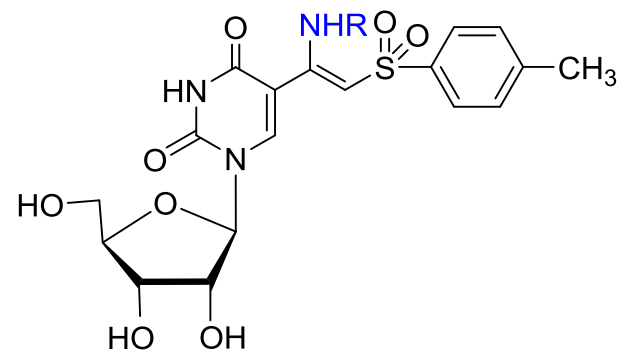

$32 \mathrm{R}=\mathrm{H}$

$33 \mathrm{R}=1$-Butyl

Scheme 40. Substitution of halogen atoms of 5-( $\beta$-halovinyl) sulfone of uridine and 2'deoxyuridine with amino group

Interestingly, treatment of $E$ vinyl sulfone 10 with methanolic ammonia for $3 \mathrm{~h}$ gave (Z)5-(1-amino-2-tosylvinyl) uridine $\mathbf{3 2}$ in $84 \%$ yields with a complete inversion of configuration (Scheme 41). The plausible mechanism of the reaction can be explained as depicted in the Scheme 42. 

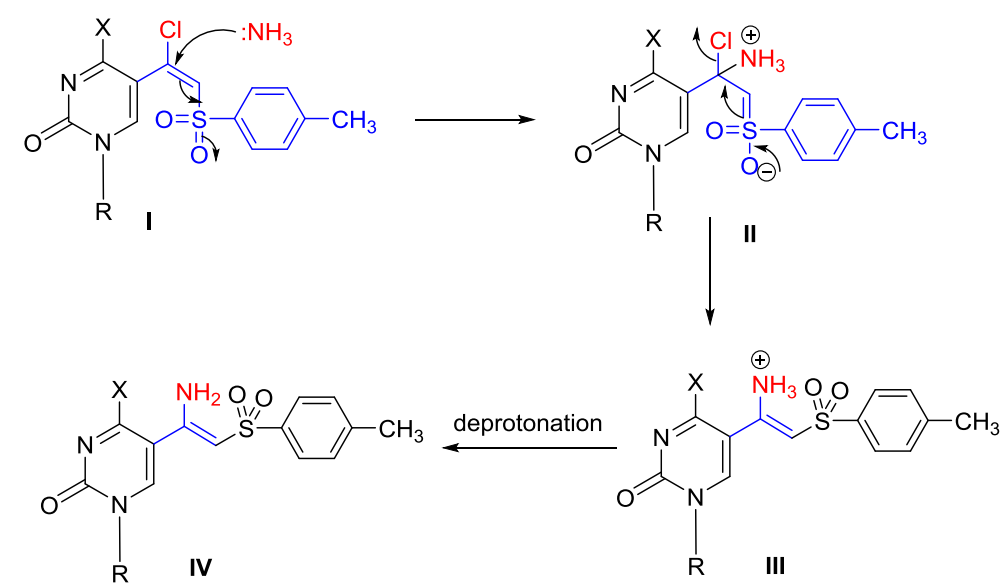

Scheme 41. Plausible mechanism for the substitution of chlorine atom by amino group in $(\beta$-halo)vinyl sulfones

If the nucleophiles after the addition-elimination type reactions are able to form hydrogen bonding with the oxygen atom of the sulfonyl moiety, then the products possess $\mathrm{Z}$ stereochemistry, ${ }^{89}$ means inversion of configuration takes place as the halo vinyl substrates have $\mathrm{E}$ stereochemistry. When $\beta$-halo vinyl sulfones were treated with methanolic ammonia, it gave the $\mathrm{Z}$ isomer exclusively (Figure 7).

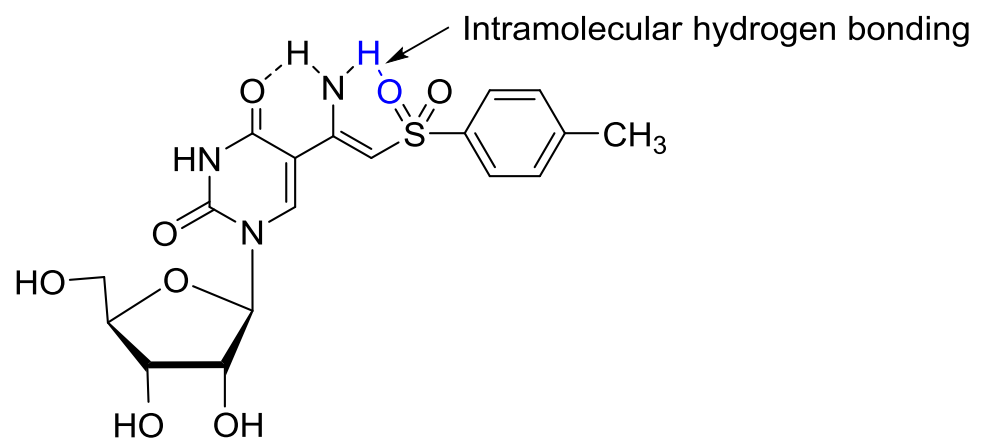

Figure 7. Intramolecular hydrogen bonding of amino group with oxygen atom of uracil ring and sulfone moiety

The $Z$ stereochemistry of the vinylic position of ( $\beta$-aminovinyl) sulfone analogue $\mathbf{3 2}$ was confirmed by Tsui from X-ray crystallography. ${ }^{89}$ However, crystal was not obtained from the 
5 modified amino vinyl sulfone analogue $\mathbf{3 2}$ as it readily converted into corresponding $\beta$-keto sulfone analogue during the approach to get crystal in $\mathrm{MeOH}$ or $\mathrm{CH}_{3} \mathrm{CN}$ solvent.<smiles>CC(=O)c1ccc(/C(=C/S(=O)(=O)c2ccccc2)NN)cc1</smiles>

33

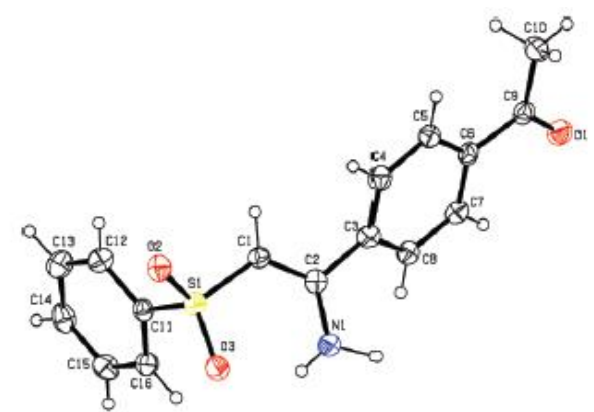

Figure 8. Structure of $\beta$-aminovinyl sulfone analogue 33 (left) and its X-ray structure (right). ${ }^{89}$

The Z-5-( $\beta$-amino)vinyl sulfone of uracil derivative $\mathbf{3 5}$ was synthesized from the corresponding $E$-5-( $\beta$-chloro)vinyl sulfone analogue $34 .{ }^{90}$ In the NOESY experiment correlation was observed between the vinylic and H6 proton in 35. This correlation is only possible when vinyl position possesses $Z$ stereochemistry. It is important to mention that in similar NOESY experiment with E-5-( $\beta$-chloro)vinyl sulfone 34 no correlation observed between those two protons (Figure 9).

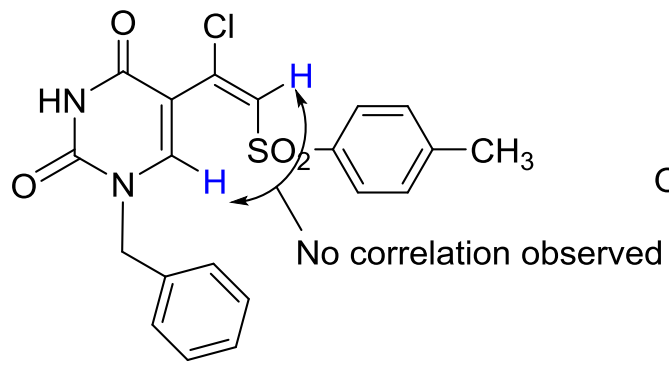

34

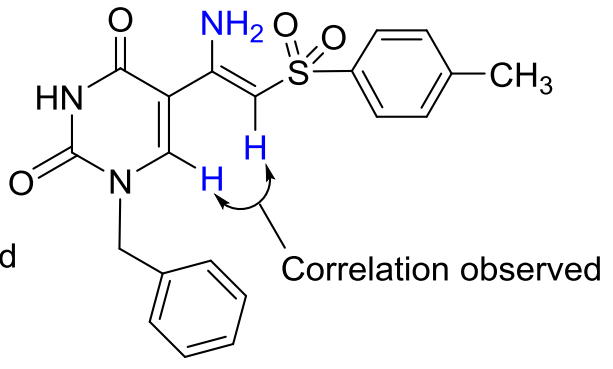

35

Figure 9. NOESY correlation between the vinylic proton and the H6 proton 
Interesting findings from the NOESY experiments and the recent literature report by Tsui leads me to draw the conclusion that the vinylic position of the novel ( $\beta$-amino)vinyl sulfone analogue $\mathbf{3 2}$ possesses $Z$ stereochemistry.

However, when $\beta$-halo vinyl sulfones were treated with butyl amine, the product $\mathbf{3 3}$ was a mixture of $E / Z$ isomers. The rationale for this can be explained that amino group has two hydrogen atoms which can form two intramolecular hydrogen bondings as shown in figure 10 . The butyl amino group has only one hydrogen atom attached to the nitrogen atom which can form hydrogen bonding either with oxygen atom of the uracil base or oxygen atom of the sulfonyl group. This competition might results the mixtures of $E / Z$ isomers.

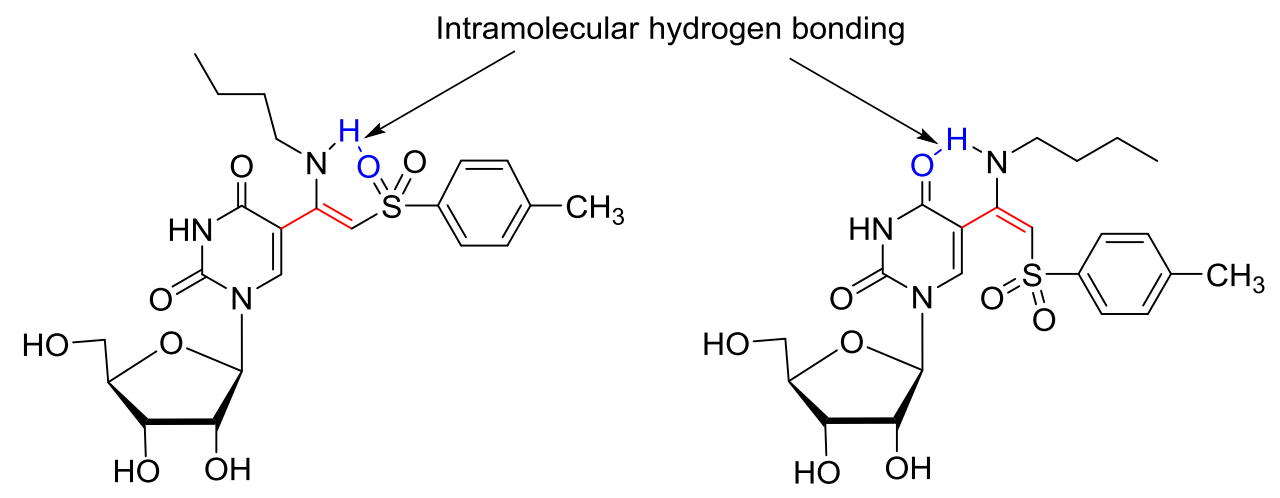

Figure 10. Intramolecular hydrogen bonding in ( $\beta$-aminobutyl)sulfone 33

To study the kinetics of the addition-elimination reactions of these halo vinyl sulfone and to compare reactivity of these halovinylsulfones with the unhalogenated vinyl sulfones, the (E)-5-(2-tosylvinyl)uridine (36) was synthesized. ${ }^{115}$ Thus treatment of 5 with $p$-toluenesulfinic acid in the presence of copper(II) acetate catalyst followed by acetyl deprotection gave $\mathbf{3 6}$ with $35 \%$ yield (Scheme 43$)$. 


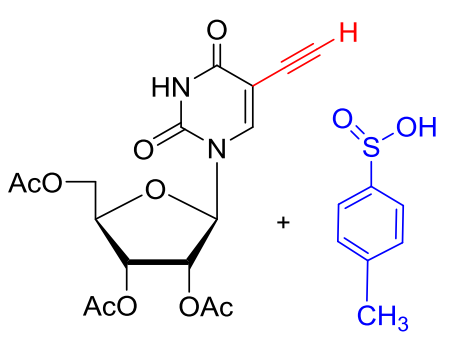

5

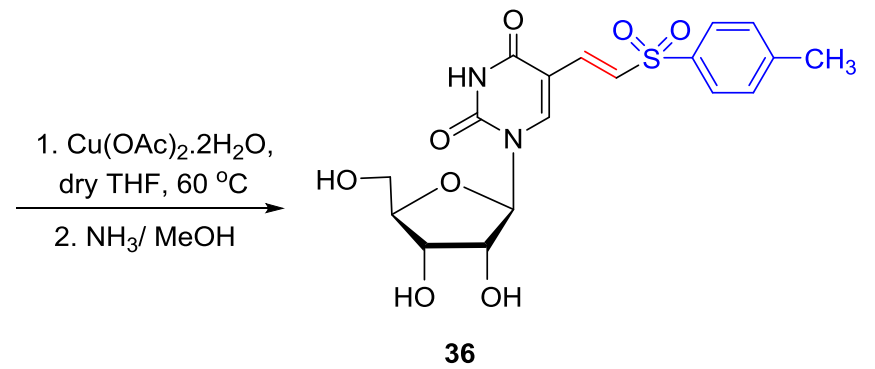

36

Scheme 42. Synthesis of (E)-5-(2-tosylvinyl)uridine

The structure of $\mathbf{3 6}$ was established by applying different NMR techniques and molecular weight was determined by high resolution mass spectrometry. In ${ }^{1} \mathrm{H}$ NMR, two vinylic proton showed two doublet at 7.19 and $7.62 \mathrm{ppm}$ respectively. The coupling constant value was 15.0 $\mathrm{Hz}$ which indicated that the vinylic position possessed $E$ stereochemistry. In addition the tosyl peak was observed at 7.39 and 7.73 ppm respectively. The experimental mass of $\mathbf{3 6}$ was $447.0802[\mathrm{M}+\mathrm{Na}]^{+}$which is very much similar to the theoretical value 447.0833.

\subsubsection{Kinetics of addition-elimination reaction of (E)-5-(1-halo-2-tosylvinyl)uridine}

The kinetics of the addition-elimination reactions was studied by examining reaction profile of $\beta$-halovinylsulfones $10,11,12$, or 36 with $n$-propenthiol. Kinetic data for the reactions between $\beta$-halovinylsulfone 10, 11, 12, and 36 and $n$-propanethiol in the presence of TEA were acquired by ${ }^{1} \mathrm{H}$ NMR at room temperature using a Bruker $400 \mathrm{MHz}$ spectrometer. For each of the experiment propanethiol $\left(200 \mu \mathrm{L}\right.$ of the $29.8 \mathrm{mM}$ in DMSO- $\left.d_{6}\right)$ was added to NMR tube containing $200 \mu \mathrm{L}$ of the $29.8 \mathrm{mM}$ of $\beta$-halovinylsulfone $(\mathbf{1 0 , 1 1 , 1 2}$, and 36) in DMSO- $d_{6}$ and the proper ratio of PrSH to substrates $(\mathbf{1 0}, \mathbf{1 1}, \mathbf{1 2}$, and 36) was confirmed by proton integration. Then TEA $\left(200 \mu \mathrm{L}\right.$ of the $29.8 \mathrm{mM}$ in DMSO- $\left.d_{6}\right)$ was added for the total $9.93 \mathrm{mM}$ concentration of substrates and the reaction mixture was scanned once every 5 minutes over first 30 minutes and later every $10 \mathrm{~min}$. The procedure was repeated in 
duplicate. For each of the halovinyl sulfones 10, 11, 12 tested, proton spectra showed formation of the substitution product 27. However, unsubstituted vinyl sulfone $\mathbf{3 6}$ was unreactive in that nucleophilic environment. The profile for the reaction was measured by integrating disappearance of the signal of $\mathrm{H6}$ of substrate 10, $\mathbf{1 1}$, and $\mathbf{1 2}$ at 8.25, 8.21, and $8.07 \mathrm{ppm}$ and appearance of $\mathrm{H} 6$ signal at $7.96 \mathrm{ppm}$ for the product 27 on ${ }^{1} \mathrm{H}$ NMR spectra. The y-intercept for each plot was set up to $1 /[$ starting $\beta$-halovinylsulfone concentration]. Plots show data collected within $\sim 40 \%(\mathbf{1 0}), \sim 55 \%$ (11) and $\sim 60 \%$ (12) conversion to the $\beta$ (propylthio)vinylsulfone (27) product.

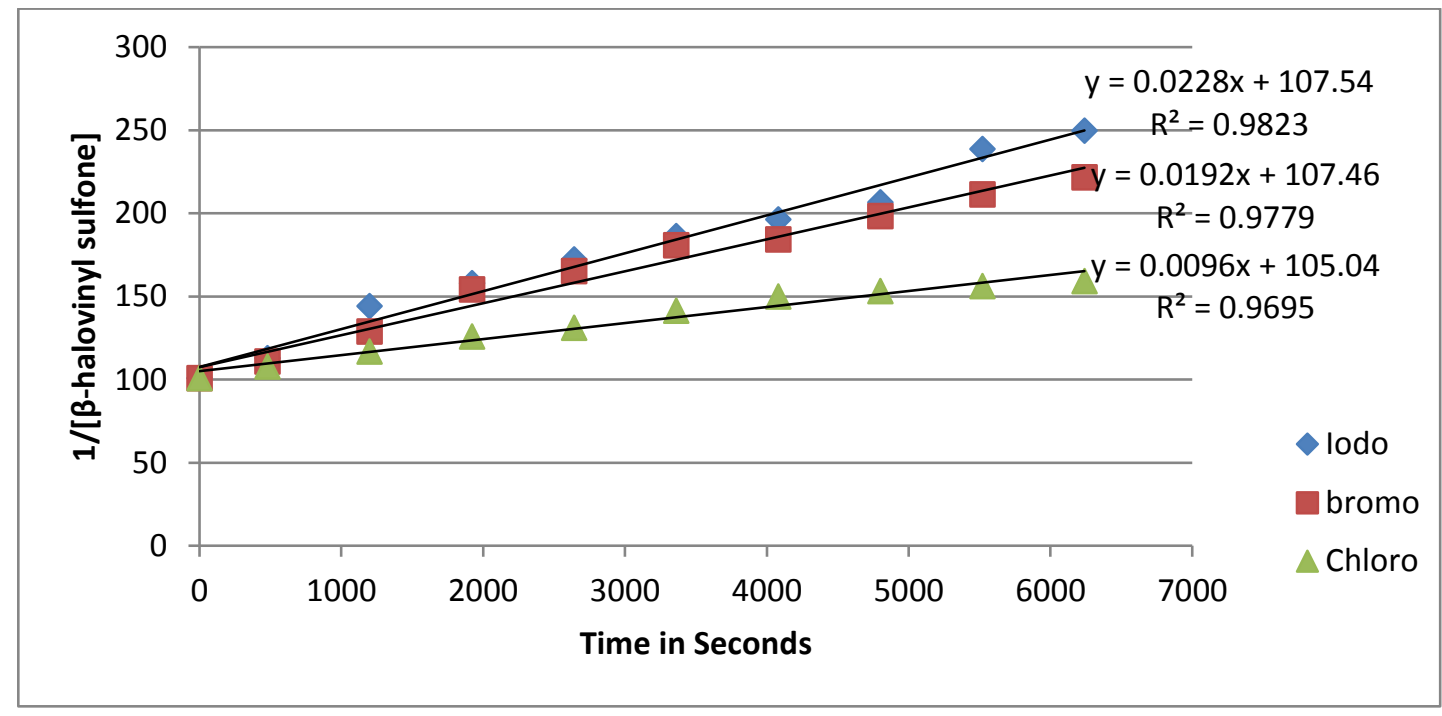

Figure 11. The rate plots for the reactions between 10 (chloro), 11 (bromo), and 12 (iodo) with n-propanethiol in the presence of TEA. The second order rate constant was calculating by plotting $1 /[\beta$-halo vinyl sulfone $]$ as a function of time

The calculated second order rate constants for the substitution reaction were $0.0096 \mathrm{M}^{-1} \mathrm{~s}^{-1}$, $0.0192 \mathrm{M}^{-1} \mathrm{~s}^{-1}$ and $0.0228 \mathrm{M}^{-1} \mathrm{~s}^{-1}$ for $\mathbf{1 0}$ (chloro), $\mathbf{1 1}$ (bromo), and $\mathbf{1 2}$ (iodo), respectively. Plots depicted in Figure 11 showed that iodo and bromo vinylsufones are more reactive compare to chloro counterpart $(\mathrm{I} \geq \mathrm{Br}>\mathrm{Cl})$. 


\subsubsection{Mechanism and stereochemistry}

When $\beta$-substituted vinylsulfones were dissolved in protic polar deuterated solvent the alpha vinylic proton exhibited interesting behavior. Thus, when $\beta$-amino vinyl sulfone $\mathbf{3 2}$ was dissolved in $\mathrm{D}_{2} \mathrm{O}$ or $\mathrm{MeOH}-d_{4}$ the alpha-vinylic proton underwent quick exchange with deuteriumto give deuterium labeled compound 37 (Scheme 44).

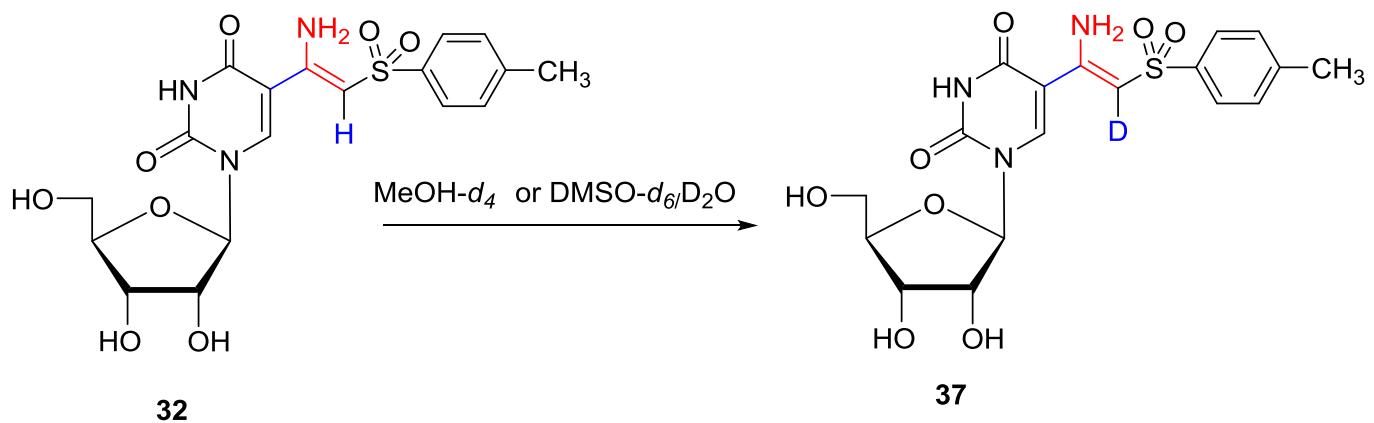

Scheme 43. Deuterium exchange at vinylic proton of 5- ( $\beta$-aminovinyl) sulfone of uridine to afford $\alpha$-deuterated analogue

When 10 was dissolved in $\mathrm{MeOH}-d_{4}$, no deuteration at the vinyl proton was observed. However in the presence of triethyl amine deuteration of the vinylic proton was observed and gave deuterated compound 38 (Scheme 45). However, the rate of deuteration of chlorovinyl analogue $\mathbf{1 0}$ was slow compare to the amino analogue $\mathbf{3 2}$.

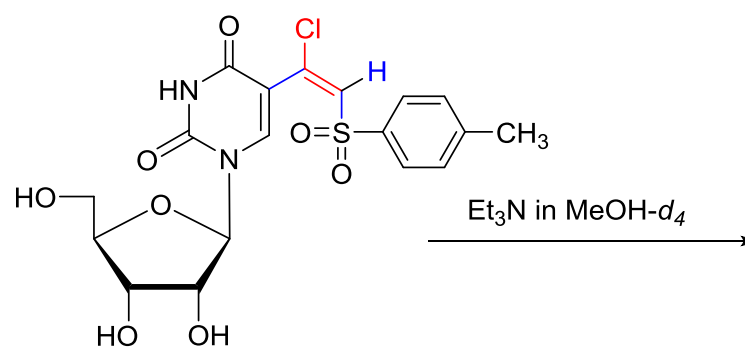

10

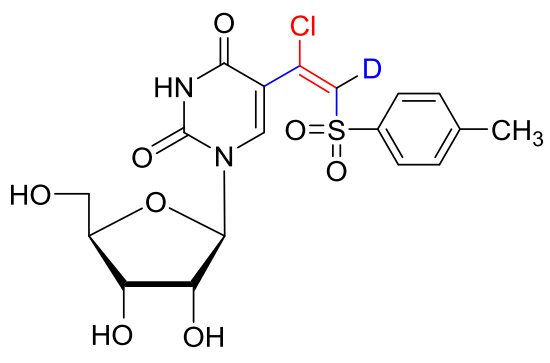

38

Scheme 44. Deuterium exchange at the vinylic proton of $\beta$-chloro analogue

In the presence of propanethiol and triethyl amine fast deutaration was observed and afforded the $\alpha$-deuterated compound $\mathbf{3 9}$ as shown in Scheme 46. 


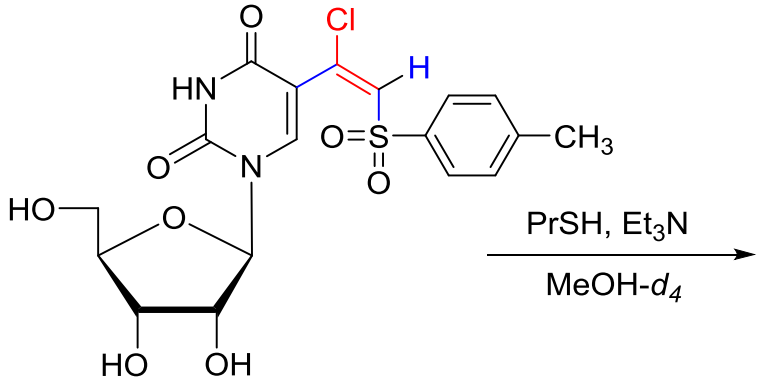

10

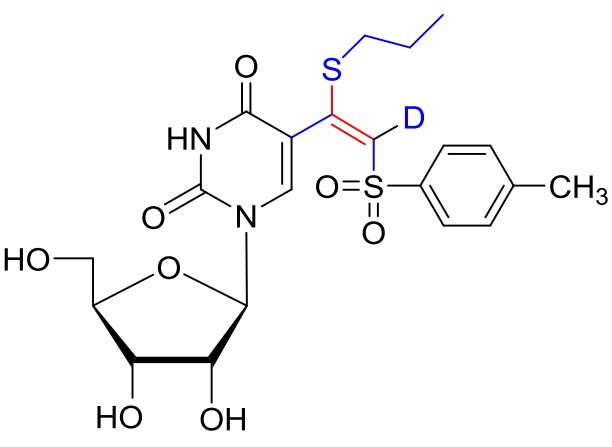

39

Scheme 45. Deuterium exchange at vinylic proton of $\beta$-chloro sulfone to give $\alpha$-deuterated $\beta$-propanethio-analogue

From these observations the plausible mechanism of the addition-elimination reaction could be proposed (Scheme 47). The $\beta$-carbon of the vinyl sulfone is vulnerable to the nucleophilic attack as it is partially positive due to the inductive effect of the halogen atom and neighboring electron withdrawing sulfonyl moiety. So, subsequent attack of the nucleophile and elimination of halogen atom give compound 43. It is also observed that under nucleophilic condition $\left(\mathrm{PrSH} / \mathrm{MeOH}-d_{4} / \mathrm{TEA}\right)$ the vinylic proton is exchanged by deuterium to give compound 44. It is entirely possible that enolate like basicity of intermediate $\mathbf{4 1}$ is quenched by deuterium and subsequent deprotonation of more acidic proton of intermediate 42 gave deuterium incorporated compound 44 . 


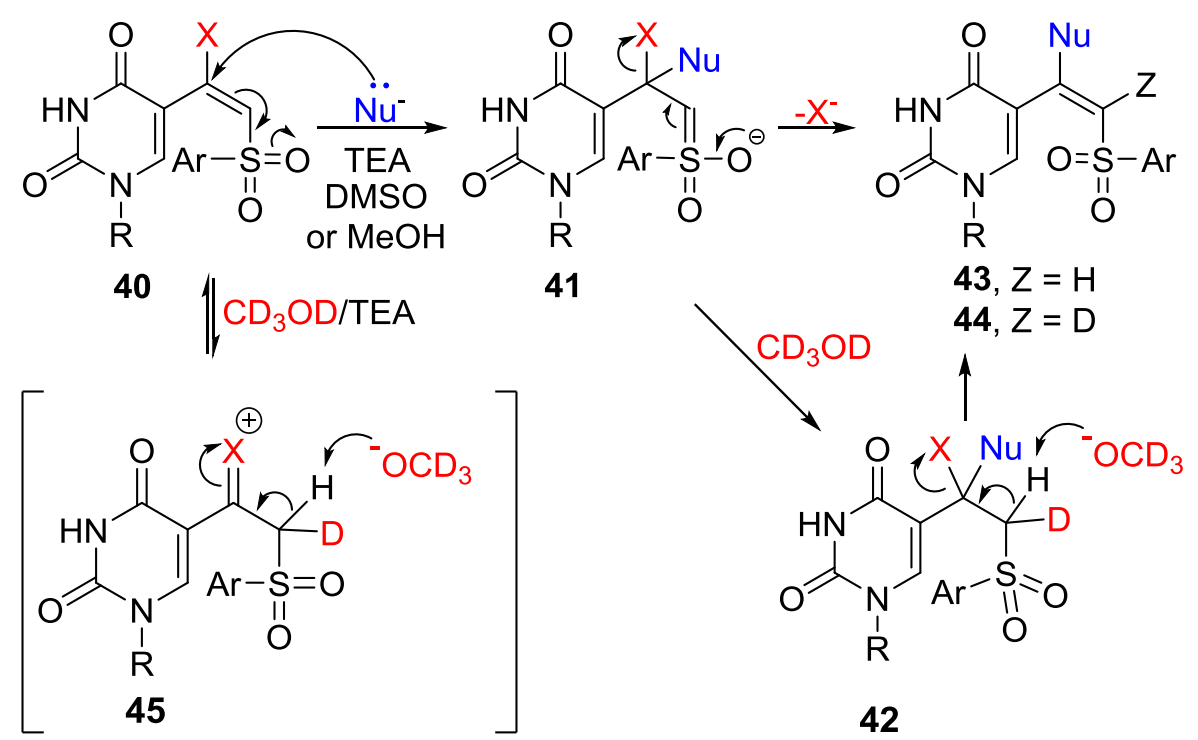

Scheme 46. Plausible mechanism for substitution of halogen in $\beta$-halovinyl sulfones with nucleophiles

Deuterium exchange was observed when $\beta$-amino vinyl sulfone $\mathbf{3 1}$ is treated with DMSO$d_{6} / \mathrm{D}_{2} \mathrm{O}$ or $\mathrm{MeOH}-d_{4}$. However, vinyl thiether analogue 27 did not undergo such exchange in $\mathrm{MeOH}-d_{4}$ in the presence of TEA. Although deuterium exchange of the vinyl proton was observed in the chlorovinyl sulfone analogue $\mathbf{1 0}$ in $\mathrm{MeOH}-d_{4}$ in the presence of TEA, this exchange was slower compare to the aminovinyl analogue 31. In addition, in the presence of nucleophilic condition (PrSH/ TEA/ MeOH- $d_{4}$ ) deuterium exchange occured faster compare to the absence of propane thiol. From this behavior of chlorovinyl compound 10, it is believed that faster deuterium acquision occurs through intermediate $\mathbf{4 2}$ instead of intermediate $\mathbf{4 5}$.

It is reported in the literature ${ }^{3-4}$ that the expected $\beta$-halo vinyl sulfone should have possessed $E$ configuration at the double bond. In order to establish unequivocally the stereaochemistry in the novel nucleoside analogues, crystal of 5-(1-chloro-2tosylvinyl)uridine (10) was obtained by slow evaporation of ACN in $\mathrm{H}_{2} \mathrm{O}$. X-ray analysis of 
the single crystal of $\mathbf{1 0}$ was accuired in Dr. Raptis's Lab at FIU from the X-ray analysis $E$ stereochemistry around double bond was concretely established (Figure 12). ${ }^{90}$

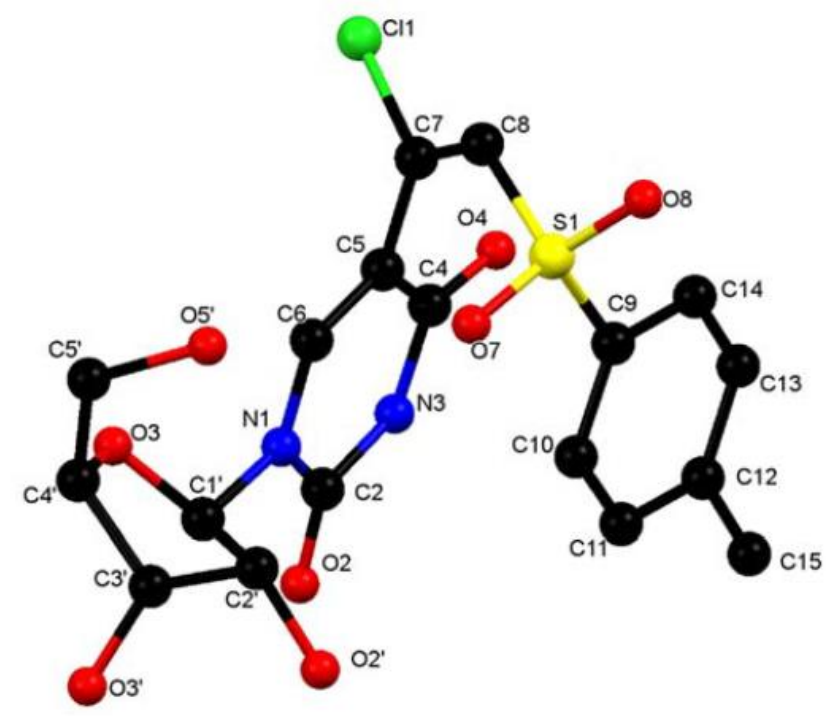

Figure 12. Ball-and-stick representation of 5-(1-chloro-2-tosylvinyl)uridine 10 showing the atom labeling scheme. $\mathrm{H}$-atoms and interstitial $\mathrm{H}_{2} \mathrm{O}$ molecules are omitted for clarity.

In 5-(1-chloro-2-tosylvinyl)uridine 5 the glycosyl torsion angle $\mathrm{C} 6-\mathrm{N} 1-\mathrm{Cl}^{\prime}-\mathrm{O} 44^{\prime}$ is $43.9^{\circ}$, and the furanose pseudorotation angle is $164.9^{\circ}\left({ }^{2} \mathrm{~T}_{3}\right.$ conformation). The $\mathrm{C}^{\prime}-\mathrm{C}^{\prime}-\mathrm{C} 5^{\prime}-\mathrm{O} 5^{\prime}$ torsion angle is $53.6^{\circ}$ and is in the $\mathrm{g}+\mathrm{gg}$ range. Nearly parallel uracil and benzene ring orientation allowed favorable $\pi-\pi$ interactions.

After addition-elimination reaction, the stereochemistry of the vinyl position of the products was studied. The crystal of the model compound 1- $N$-Benzyl-5-(1-(propylthio)-2tosylvinyl)uracil 45 was developed by the slow evaporation of acetonitrile and stereochemistry was confirmed after running X-ray of the crystal. 


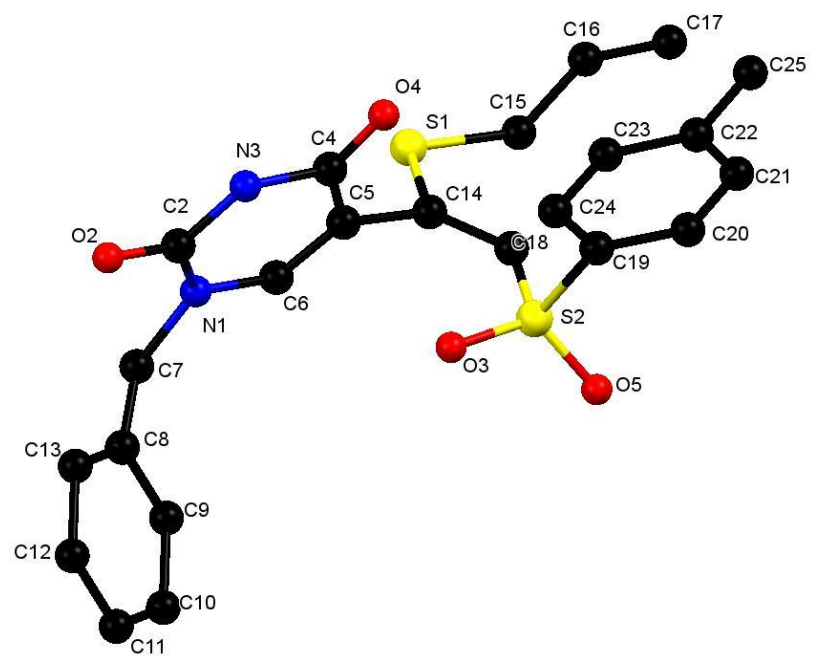

Figure 13. Ball-and-stick representation of 1- $N$-benzyl-5-(1-propanethiovinyl)uracil 45 showing the atom labeling scheme. Disordered parts and H-atoms are not shown for clarity

The 1- $N$-benzyl-5-(1-propanethiovinyl)uracil 45 crystallizes in the monoclinic $P{ }_{1} / n$ space group with the whole molecule in the asymmetric unit. The molecule contains four intermolecular H-bonds including two from the uracil base: (N1-C13: 2.867(9) $\AA$ and N3-O5: 2.920(4) §). Compare to corresponding $\beta$-ketosulfone analogue as discussed in (Section 3.2.1), the pi-pi interactions are weaker.

From the X-ray data it is clear that the propanethio analogue 45 possesses $E$ stereochemistry. That means after the addition-elimination reaction the $E$ configuration of the double bond remained unchanged for that substituted product. As an amino group can form hydrogen bonding with oxygen atom of the tosyl group and the uracil moiety, it was interesting to explore the stereochemistry of the double bond of the nucleoside analogue 5-(1amino-2-tosylvinyl) uridine 32. As crystal of amino compound was not obtained, the stereochemistry of the double bond having amino group was determined by analyzing the 1$N$-benzyl-5-(1-amino-2-tosylvinyl)uracil (35) by NOESY techiques. In a NOESY experiment, 
the vinyl proton of chloro compound did not show any correlation with H6 proton while in the amino compound the vinyl proton showed strong correlation with the corresponding H6 proton (Figure 9). This correlation could be only possible if the double bond of the vinilic position possesses $Z$ stereochemistry. So, the amino analogue $\mathbf{3 1}$ has $Z$ stereochemistry at the double bond due to the formation of hydrogen bonding of the amino group with the sulfonyl moiety of the tosyl group. The $Z$ stereochemistry at the double bond of analogue $\mathbf{3 1}$ is totally consistent with the literature report published by Tsui et al. ${ }^{89}$

\subsection{Chemistry of 5-(2-tosylacetyl)uracil and cytosine nucleosides}

The C-5 position of the pyrimidine nucleoside is an active site where different reactive functional groups such as alkene, alkyne, azide etc can be incorporated to synthesize novel pyrimidine nucleosides. ${ }^{116}$ So, acetylene functional group was incorporated at the C-5 position of the pyrimidine nucleosides. The 5-(1-chloro-2-tosylvinyl)pyrimidine nucleosides were synthesized via halovinyl sulfonylation reactions as discussed above in section 3.1.1. These ( $\beta$-chloro)vinyl sulfones 46 were converted into the corresponding $\beta$-keto sulfones 47 by the treatment of $\mathbf{4 6}$ with methanolic ammonia followed by acid hydrolysis of the intermediary $(\beta$ amino)vinyl sulfone (Scheme 48).

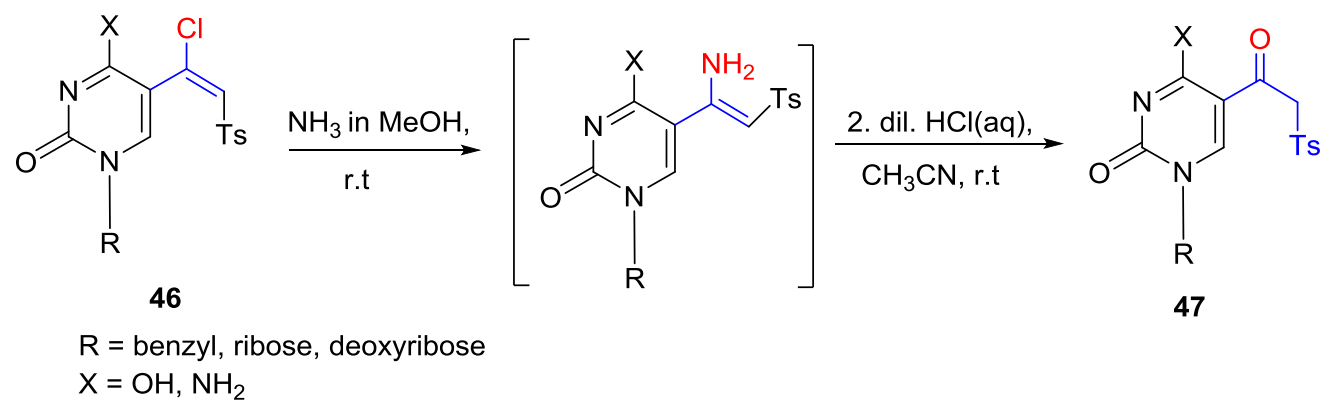

Scheme 47. Synthesis of $\beta$-keto sulfone from $\beta$-chloro vinyl sulfone analogue via substitution by ammonia and acid hydrolysis 
The plausible mechanism for the conversion of $\mathbf{4 6}$ to $\mathbf{4 7}$ can be explained in the following way. Firstly, conversion of ( $\beta$-chloro)vinyl sulfone (e.g. 46) into ( $\beta$-amino)vinyl sulfone occurs via addition-elimination reactions as depicted in Scheme 42. The basic amino group in ( $\beta$-amino)vinyl sulfone $\mathbf{I}$ accepts proton in acidic media and developed positive charge at the nitrogen atom to give intermediates II (Scheme 49). Water attacks at the $\beta$-carbon of II follow by elimination of ammonia pathway afford intermediate IV. Subsequent deprotonation and tautomerization generates $\beta$-keto sulfone $\mathbf{V I}$.
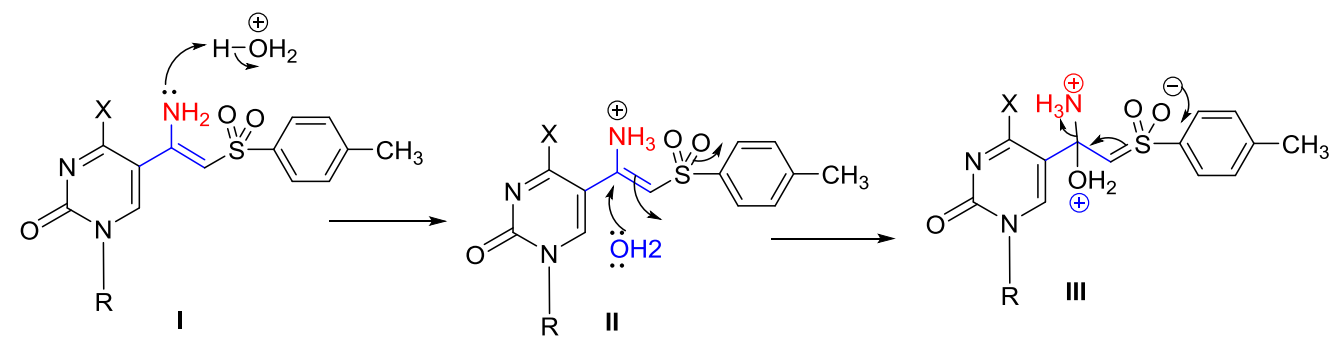

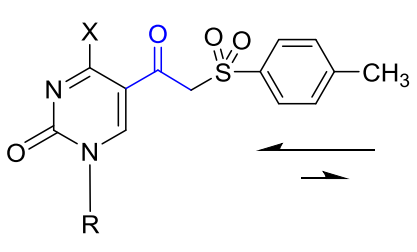

VI
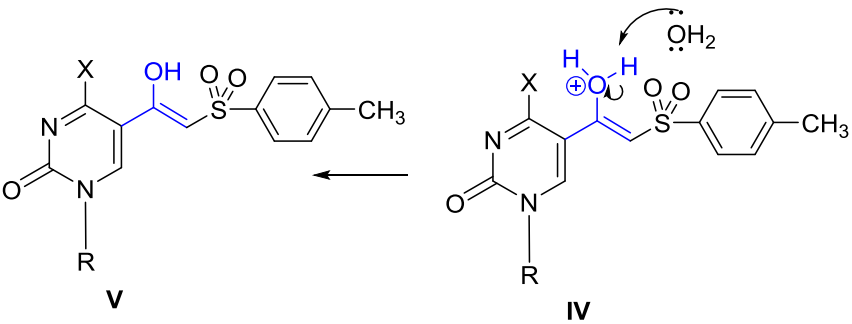

Scheme 48. Plausible mechanism of the conversion of $\beta$-amino sulfone into $\beta$-keto sulfone

Since the $\alpha$-proton of $\beta$-keto sulfone is acidic $(\mathrm{pKa}=\sim 9-10)$ and under sufficient basic conditions the $\alpha$-carbon can trap electrophile. From this assumption, different electrophiles can be inserted at the $\alpha$-carbon of the $\beta$-keto sulfone analogues as illustrates in Scheme 50. 


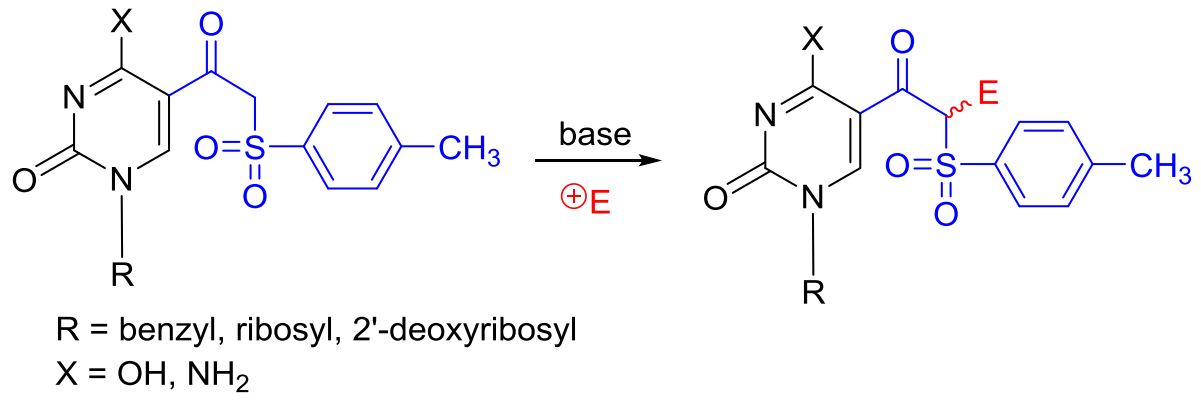

Scheme 49. General scheme for the trapping of eletrophiles at the $\alpha$-carbon of $\beta$-keto sulfone

The plausible mechanism of this reaction is very straightforward and is depicted in Scheme 51. First the base picks up an acidic proton from the $\alpha$-carbon and thus generates carbanion II which can be stabilized by forming enolate ion III. The $\pi$ electron of the enolate ion attacks the electrophile and gives product IV as mixture of isomers. The rationale of forming products IV can be explained from the $\mathrm{sp}^{2}$ hybridization of $\alpha$-carbon of III which can attack electrophile either from the top face or bottom face.<smiles>[X]c1nc(=O)n([R])cc1C(=O)C(CC(=O)O)S(=O)(=O)c1ccc(C)cc1</smiles><smiles>[X]c1nc(=O)n([R])cc1C(=O)[C@@H](C)S(=O)(=O)c1ccc(C)cc1</smiles>

Scheme 50. Plausible mechanism of electrophile trapping at the $\alpha$ - carbon 


\subsubsection{Synthesis of 5-(2-tosylacetyl)uracil nucleosides}

Initially the synthesis of uracil 5-( $\beta$-keto)sulfone were attempeted by pyridine-catalyzed oxidative radical reaction of 5-ethynyluracil analogues. Thus, treatment of 1- $N$-benzyl-5ethynyluracil 48 with $p$-toluenesulfinic acid and pyridine in the presence of oxygen afforded 5-( $\beta$-keto)sulfone derivative $\mathbf{4 9}$ with the yield of $44 \%$ (Scheme 52).<smiles>C#Cc1cn(Cc2ccccc2)c(=O)[nH]c1=O</smiles>

48

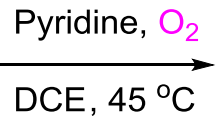<smiles>Cc1ccc(S(=O)O)cc1</smiles><smiles>Cc1ccc(S(=O)(=O)CC(=O)c2cn(Cc3ccccc3)c(=O)[nH]c2=O)cc1</smiles>

49

Scheme 51. Synthesis of 5-( $\beta$-keto)sufone of 1- $N$-benzyl-5-ethynyluracil

The 5-( $\beta$-keto)sulfone 49 was characterized by NMR techniques and mass was confirmed from HRMS-TOF analysis. In ${ }^{1} \mathrm{H}$ NMR the $\alpha$-methylene peak was observed at $4.98 \mathrm{ppm}$ and three peaks from tosyl group appeared at 2.42, 7.29 and $7.79 \mathrm{ppm}$. In ${ }^{13} \mathrm{C}$ NMR the methylene carbon peak appeared at $52.9 \mathrm{ppm}$ while $\beta$-carbonyl carbon peak was detected at $183.8 \mathrm{ppm}$.

Treatment of acetyl protected 5-ethynyl-2'-deoxyuridine $\mathbf{4}$ with $p$-toluenesulfinic acid by pyridine-catalyzed aerobic oxidative reaction afforded protected 5-( $\beta$-keto)sulfone analogue 50a with 16\% yield (Scheme 53). Analogous treatment of protected 5-ethynyluridine 5 with sulfinic acid afforded $\mathbf{5 0 b}$ with $20 \%$ yield. The low yield of these reactions could be explained by the acid sensitive $\beta$-glycosidic bond which cleaved during the reaction. Both of the products were characterized using NMR techniques. 

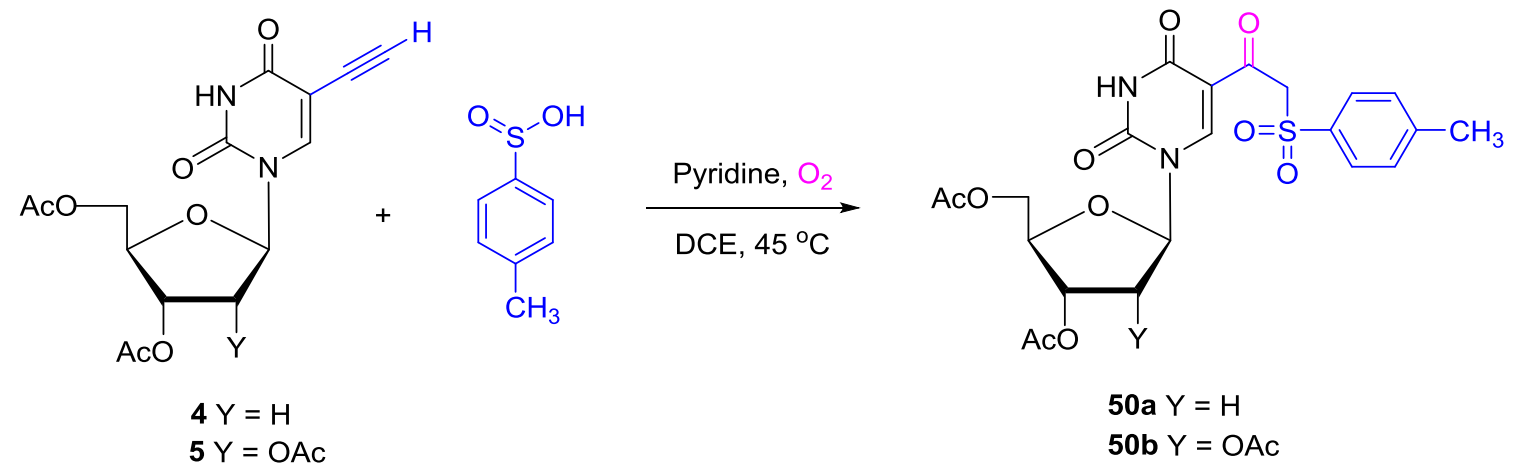

Scheme 52. Synthesis of 5-( $\beta$-keto)sufone of protected uridine from the corresponding 5ethynyl substrates

In 50a the two peaks of $\alpha$-methylene proton were observed at 4.95 and $5.05 \mathrm{ppm}$ and the three tosyl peaks appeared at 2.45, 7.35, and $7.85 \mathrm{ppm}$. In 50b the two peaks from $\alpha$ methylene protons appeared at 4.90 and $5.10 \mathrm{ppm}$. The chemical shift value of $\mathrm{H} 6$ for both 50a and 50b were appeared in the relatively downfield region compared to the 5ethynylsubstrates 4 and $5(8.50 \mathrm{ppm} v s 7.83 \mathrm{ppm})$ probably the result of the incorporation of electron withdrawing $\beta$-keto sulfonyl moiety at the $\mathrm{C} 5$ position.

As a result of the low yield of the oxidative radical process, the 5-( $\beta$-keto)sulone of uracil nucleosides were synthesized from their 5-( $\beta$-halo)vinylsulofne precursors by applying one pot synthetic protocol as depicted in Scheme 48. Thus, acetyl protected (8) or unprotected (910) $\beta$-chlorovinyl sulfone analogues of uracil nucleosides were efficiently converted into corresponding $\beta$-keto sulfones (51-52) by a one pot synthetic protocol. Thus, treatment of the vinyl sulfones (8-10) with methanolic ammonia gave $\beta$-amino vinyl sulfones in quantitative yield. Subsequent acid hydrolysis of these $\beta$-amino vinyl sulfones in acetonitrile gave $\beta$-keto sulfones in high yield. Analogoulsy, acetyl protected $\beta$-chlorovinyl sulfones $\mathbf{8}$ was converted into corresponding $\beta$-keto sulfone with $60 \%$ (52) yields and unprotected chlorovinyl sulfone 
analogues 9 and 10 into corresponding $\beta$-keto sulfones afforded $74 \%$ and $70 \%$ yields respectively (Scheme 54).
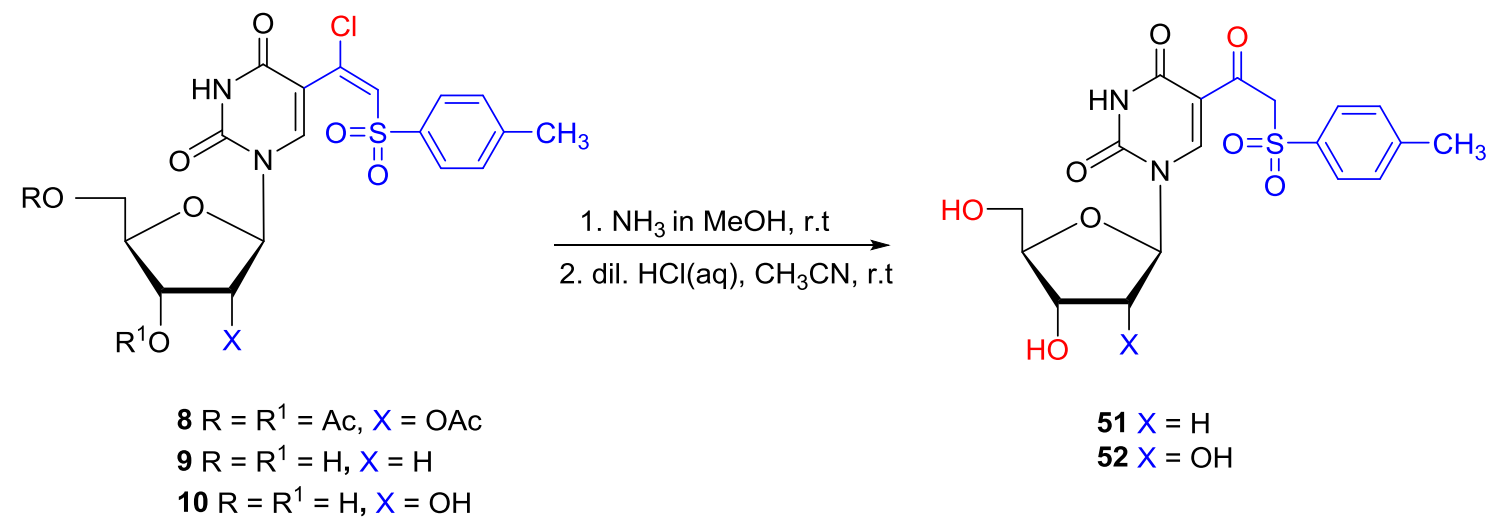

Scheme 53. Synthesis of 5-( $\beta$-keto)sulfone of uridine and 2'-deoxyuridine from their ( $\beta$ chlorovinyl) sulfone analogue

The structure of ( $\beta$-keto) sulfone analogues $\mathbf{5 1}$ and $\mathbf{5 2}$ were established using different NMR $\left({ }^{1} \mathrm{H}, \mathrm{COSY}, \mathrm{HMQC}, \mathrm{DEPT}-135\right.$ and $\left.{ }^{13} \mathrm{C}\right)$ techniques. In $\mathbf{5 1}$ and $\mathbf{5 2}$, a higher chemical shift value of $\mathrm{H} 6$ proton was observed at 8.68 and $8.80 \mathrm{ppm}$ respectively as compared to the chemical shift value of $\mathrm{H} 6$ proton in the corresponding $\beta$-chlorovinyl sulfone substrates 8-10. The reason of higher chemical shift value of the keto analogues can be explained by the incorporation of electron withdrawing keto group at C5 position. In compounds $\mathbf{5 1}$ and $\mathbf{5 2}$, the peaks of methylene group appeared at 5.15 and 5.14 ppm respectively. In $\beta$-keto sulfone analogues $\mathbf{5 1}$ and 52, characteristics peaks of carbonyl carbon were observed at 184.0 and $185.0 \mathrm{ppm}$ respectively. In addition, distinct peak of methylene carbon peaks were observed at 64.0 and $64.3 \mathrm{ppm}$ respectively. In agreement with the proton NMR there was also higher chemical shifts value of C6 carbon peaks those were 149.0 and 149.3 ppm respectively. The mass obtained from the high resolution mass spectroscopy (HRMS) was in accord with the calculated value. 
The single crystal of 1-N-benzyl-5-(2-tosylacetyl)uracil (49) for X-crystallography was obtained by diffusion crystallization (ethyl ether into a $\mathrm{MeOH}$ solution) of the corresponding aminovinylsulfone 35. Compound 49 was crystallized in the triclinic $P-1$ space group with the whole molecule in the asymmetric unit. Several intermolecular H-bonds stabilize the crystal structure, including a uracil N-O H-bond (N3-O4: 2.900(3) Å) (Figure 14). The ( $\beta$-keto) sulfone analogue 49 is also stabilized by an intermolecular $\mathrm{C}-\mathrm{H}-\pi$-interaction between the tosyl methyl group and the phenyl ring from the benzyl group $(\mathrm{C}(\mathrm{H})$-centroid distance: 3.893 $\AA$ ). The $\pi-\pi$ interaction usually present between the uracil and the tosyl groups is weak or negligible in this analogue possibly due to other $\mathrm{H}$-bonding and $\mathrm{C}-\mathrm{H}-\pi$ interactions mentioned above.

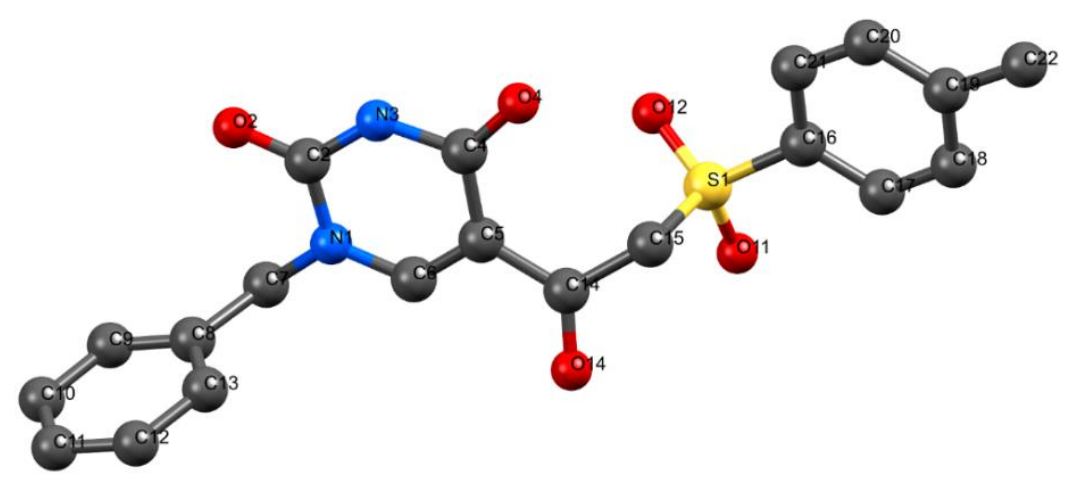

Figure 14. Ball-and-stick representation of 1-N-benzyl-5-(2-tosylacetyl)uracil (49); Hatoms have been hidden for clarity 


\subsubsection{Electrophile trapping at the $\alpha$ - carbon of the corresponding $\beta$-keto sulfone}

Since the $\alpha-\mathrm{CH}_{2}$ proton in $\beta$-keto sulfones is acidic $(p \mathrm{Ka}=10-11)$ the $\beta$-keto sulfone analogues (51-52) when treated with different electrophile sources such as benzyl bromide, methyl iodide, allyl bromide in the presence of dilute $\mathrm{NaOH}$ can serve as a convenient substrates for the synthesis of $\alpha$-alkylated products 53-56 (Scheme 55).
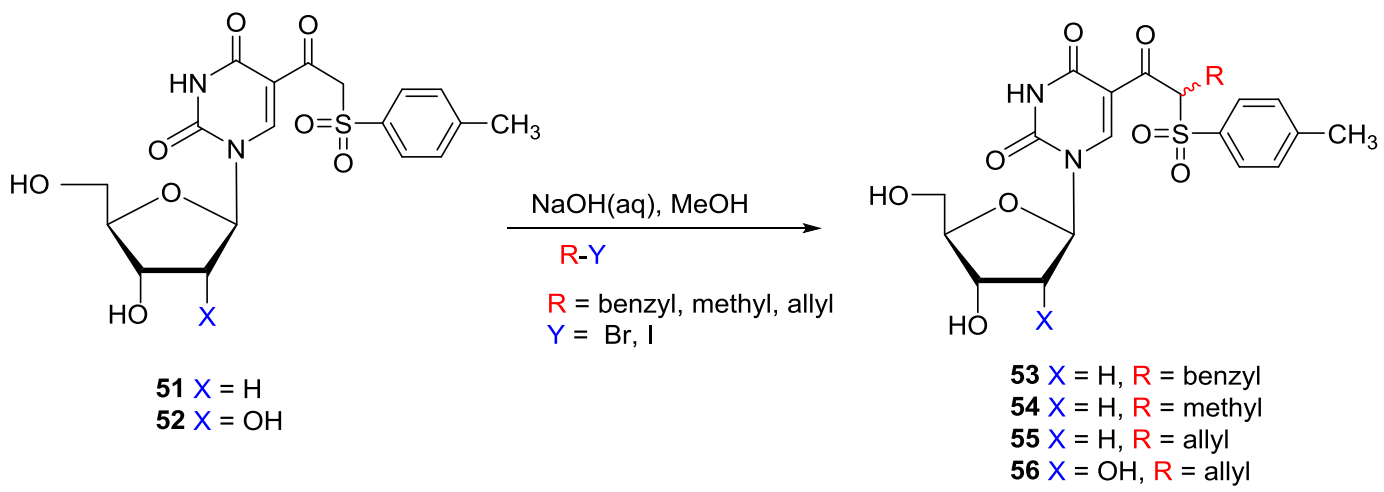

Scheme 54. Incorporation of electrophiles at the $\alpha$-carbon of ( $\beta$-keto) sulfone of uridine and 2'-deoxyuridine

It is interesting to see that during the electrophile trapping, diastereomeric products were obtained and the ratio of the diastereomers varied upon treatment with different electrophiles. When benzyl bromide was used as electrophile source 51 gave (50/50) mixtures of diasteremeric product $\mathbf{5 3}$ with $28 \%$ yield. The reason of getting low yield was the formation of byproducts. Apart from the expected diastereomeric products, there were two additional compounds were characterized. First byproduct was benzylated product at N3 position and the second one was a consequence of benzylation both at $N 3$ and $\alpha$-carbon of the $\beta$-keto sulfone. Surprisingly, dibenzylation at $\alpha$-carbon was not observed. In $\mathbf{5 3}$ two peaks of H6 proton at 8.6 and $8.7 \mathrm{ppm}$ with the integration ratio of 1:1 were observed which can be considered as the evidence for a 50/50 diastereomeric product. In ${ }^{1} \mathrm{H}$ NMR triplet at $6.5 \mathrm{ppm}$ was observed 
which indicated the $\mathrm{C}$ proton. The methylene proton of the benzyl group was detected at 3.1$3.2 \mathrm{ppm}$ as a multiplet. In addition the aromatic peak of the benzyl group was observed in the region from 7.0-7.3 ppm. In ${ }^{13} \mathrm{C}$ NMR the $\alpha$-carbon peak was observed at $55.0 \mathrm{ppm}$ while the methyl carbon peak of benzyl group was detected at $31.0 \mathrm{ppm}$. The aromatic peaks of the benzyl group were found in the region from 126.0-131.0 ppm which collapsed with the tosyl peaks. The mass obtained from the high resolution mass spectroscopy (HRMS) of compound $\mathbf{5 3}$ was $515.1437[\mathrm{M}+\mathrm{H}]^{+}$which is in accord with the calculated value.

Treatment of $\mathbf{5 1}$ with methyl iodide afforded (48/52) mixtures of diasteriomeric product 54 with the yields of $31 \%$. In addition, two other byproducts were also observed. These byproducts were characterized as $N 3$ methylated byproduct and both $N 3$ and $\alpha$-carbon methylated byproduct. Like benzylation reaction, dimethylated product at $\alpha$-carbon was not observed. In this $\alpha$-methylated analogue $\mathbf{5 4}$ two proton peaks of H6 at 8.71 and 8.73 were observed with the integral ratio 96: 104 which meant that the diasteriomeric ratio was 48/52. The $\alpha$-CH proton peak was observed at $5.96 \mathrm{ppm}$ as a quartet while the methyl peak was observed at $1.34 \mathrm{ppm}$. In ${ }^{13} \mathrm{C}$ NMR $\alpha$-C peak was observed at $66.0 \mathrm{ppm}$ and the methyl carbon peak was found at $10.0 \mathrm{ppm}$.

Analogous treatment of $\mathbf{5 1}$ with allyl bromide gave 55/45 mixtures of diastereomeric product 55 afforded $31 \%$ yield. In addition, two byproducts were also produced in similar way as discussed before. The 104: 96 integral ratio of H6 proton of the $\alpha$-substituted analogue $\mathbf{5 5}$ at $8.70 \mathrm{ppm}$ and $8.75 \mathrm{ppm}$ indicated the diastereomeric ratio is $52: 48$. The $\alpha-\mathrm{CH}$ peak was detected as a doublet at $6.15 \mathrm{ppm}$. The allyl $\mathrm{sp}^{3}$ hybridized $\mathrm{CH}_{2}$ proton peak was obtained at $2.8 \mathrm{ppm}$ and $\mathrm{sp}^{2}$ hybridized $\mathrm{CH}$ proton peak was detected at $5.6 \mathrm{ppm}$. The $\mathrm{sp}^{2}$ hybridized $\mathrm{CH}_{2}$ proton peak of allyl group was observed at $5.0 \mathrm{ppm}$. In ${ }^{13} \mathrm{C}$ NMR $\alpha$-carbon peak was observed 
at $68.0 \mathrm{ppm}$. The three carbon peaks of allyl group were found at 30.0, 118.0 and $133.0 \mathrm{ppm}$ respectively.

Treatment of $\mathbf{5 2}$ with allyl bromide afforded allyl substituted product $\mathbf{5 6}$ with the as a diastereomeric mixtures of 52/48 with the yields of $32 \%$. Two byproducts were obtained in the similar way as discussed before. No disubstitution observed at the $\alpha$-carbon. In $\mathbf{5 6}$ the integral ratio of $\mathrm{H} 6$ proton indicated the diastereomeric product was a 52/48 mixtures. The multiplet at 6.14-6.20 ppm confirmed the presence of $\alpha-\mathrm{CH}$ peak. The three vinyl peaks was observed at 2.8, 4.9 and $5.6 \mathrm{ppm}$ respectively. In ${ }^{13} \mathrm{C}$ NMR $\alpha$-carbon peak was observed at 69.0 ppm. The allyl peaks were observed at 30.0, 127.0 and $133.0 \mathrm{ppm}$ respectively.

The 5-( $\alpha$-iodo- $\beta$-keto)sulfone of 2'-deoxyuridine 56 was synthesized as an alternative probe to incorporate nucleophile at the $\alpha$-carbon of the corresponding sulfones via substitution reaction. Thus, treatment of $\beta$-keto sulfone analogue $\mathbf{5 1}$ with iodine monochloride afforded 5( $\alpha$-iodo- $\beta$-keto) sulfone of 2'-deoxyuridine $\mathbf{5 6}$ as 50/50 mixtures of diastereomeric mixtures with the yields of $44 \%$ yield (Scheme 56). Alternatively 56 was also synthesized using molecular iodine in the presence of hydrogen peroxide and acetic acid and the yield was $55 \%$.

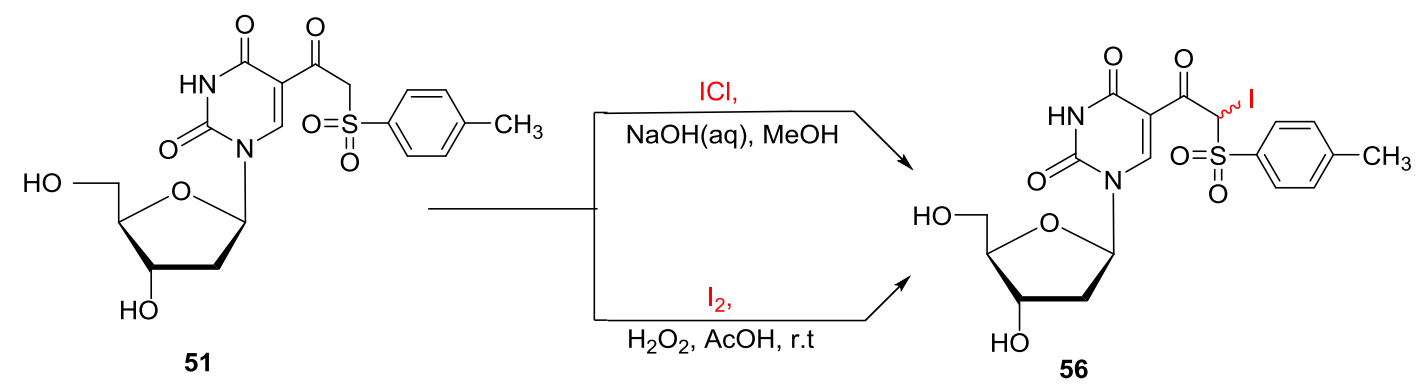

Scheme 55. Synthesis of 5-( $\alpha$-iodo $\beta$-keto sulfone) of 2'-deoxyuridine

The structuce of the novel probe $\mathbf{5 6}$ was established by using different NMR techniques. In ${ }^{1} \mathrm{H}$ NMR $\alpha$-proton of $\mathrm{CH}$ group was observed at $7.30 \mathrm{ppm}$. The higher chemical shift value 
of this proton can be explained as the incorporation of the relatively electronegative iodine atom at the $\alpha$-carbon. In ${ }^{13} \mathrm{C}$ NMR the $\alpha$-carbon peak was observed at $128.0 \mathrm{ppm}$

\subsubsection{Nucleophile trapping at the $\alpha$-carbon of the $\beta$-keto sulfones}

Treatment of 5 -( $\alpha$-iodo- $\beta$-keto $)$ sulfone 56 with propane thiol in the presence of triethylamine gave propane thio nucleophile incorporated product $\mathbf{6 0}$ as a 50/50 mixture of diasteromers and yield was $20 \%$ (Scheme 57). Relatively low yield of this reaction could be explained due to the formation of methyl ester as by product which was the major product in this reaction.

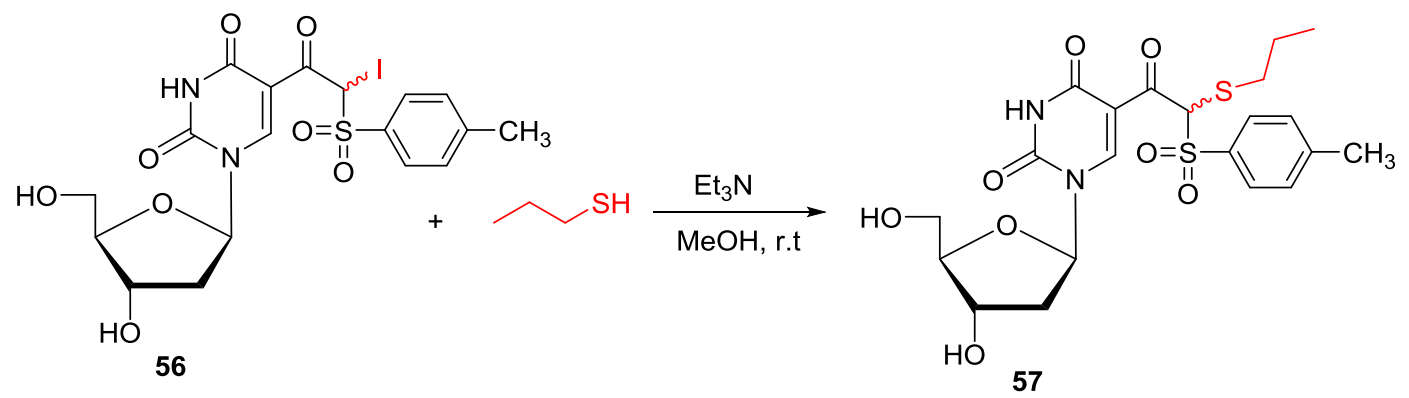

Scheme 56. Synthesis of 5- ( $\alpha$-propanethio $\beta$-keto sulfone) of 2'-deoxyuridine

The structure of the compound $\mathbf{5 7}$ was established by NMR techniques. Thus, in ${ }^{1} \mathrm{H}$ NMR three signals of the propanethio group were observed at 2.80-2.85 (multiplet), 1.40-1.60 (multiplet), and 0.85 (triplet) respectively. This ractions implied the feasibility of the incorporation the thiol residue of the important amino acid cysteine at the $\alpha$-position of the corresponding $\beta$-keto sulfone analogue $\mathbf{5 6}$.

\subsubsection{Synthesis and reactivity of 5-(2-tosylacetyl)cytosine nucleosides}

Acetyl protected $\beta$-chlorovinyl sulfone analogues (19-20) of cytosine nucleosides have been efficiently converted into corresponding $\beta$-keto sulfones (58-59). Thus treatment of the ( $\beta$-chloro)vinyl sulfones (19-20) with methanolic ammonia gave $\beta$-amino vinyl sulfones in 
excellent yield. Subsequent acid hydrolysis of these $\beta$-amino vinyl sulfones in acetonitrile gave $\beta$-keto sulfones (61-62) in good yield (Scheme 58)
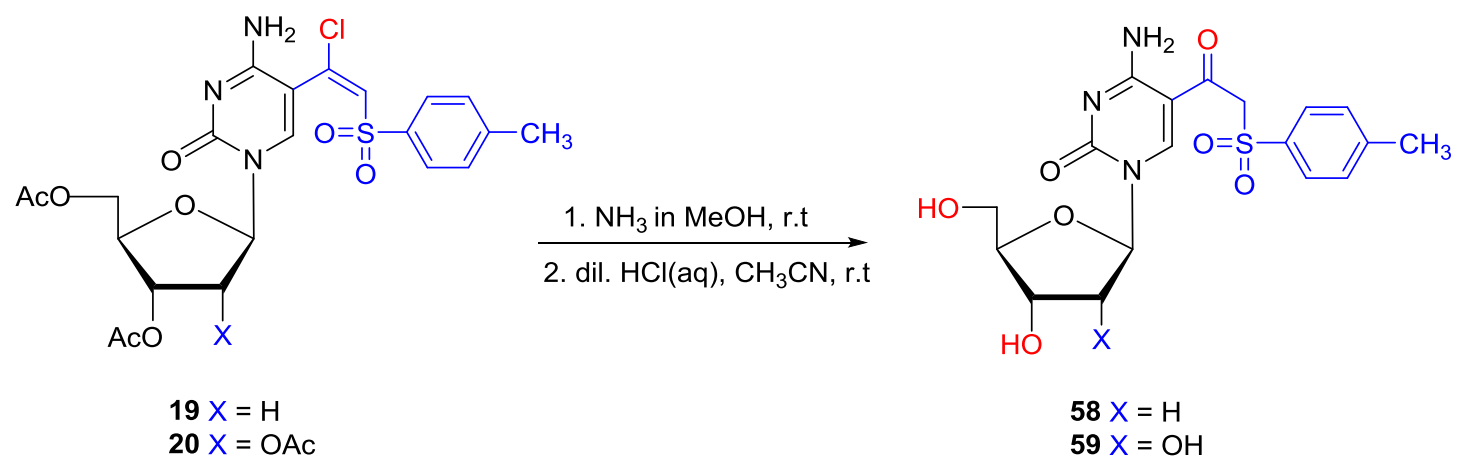

Scheme 57. Synthesis of 5-( $\beta$-keto)sulfone of cytidine and 2'-deoxycytidine

When $\beta$-chlorovinyl sulfones were treated with methanolic ammonia, it converted into the corresponding $\beta$-aminovinyl sulfones with the deprotection of the acetyl group simultaneously. When $\beta$-chlorovinyl sulfones 19 and 20 were converted into corresponding $\beta$ keto sulfone the yields were $68 \%(\mathbf{5 8})$ and $57 \%(\mathbf{5 9})$ respectively.

The structures of these $\beta$-keto sulfone analogues (58-59) were determined by applying different NMR techniques and actual mass was obtained from high resolution mass spectrometry. In $\beta$-keto sulfone analogues $\mathbf{5 8}$ and $\mathbf{5 9}$, chemical shift value of H6 proton was observed at 9.0 and 9.05 ppm respectively which was higher compare to chemical shift value of H6 proton of the corresponding $\beta$-chlorovinyl sulfone analogues 19 and 20. The higher chemical shift value of the keto analogues can be explained by the incorporation of electron withdrawing keto group at C5 position. In $\mathbf{5 8}$ methylene peak was appeared at 4.80-5.0 ppm as doublet of doublet. In 59, the same peak was observed at 4.75-4.98 ppm as doublet of doublet. In $\mathbf{5 8}$ and 59, characteristics peaks of $\beta$-keto carbonyl carbon were observed at 185.0 and $186.0 \mathrm{ppm}$ respectively. In addition characteristic peaks of methylene carbon of these compounds were also observed at 62.4 and $63.0 \mathrm{ppm}$ respectively. In complete accord with 
the proton NMR, the higher chemical shift value of C6 carbon was observed at 152.0 and $152.5 \mathrm{ppm}$ respectively. The mass obtained from the high resolution mass spectroscopy (HRMS) of compound 58 was $446.1002[\mathrm{M}+\mathrm{Na}]^{+}$. The theoretical mass of the compound was also 446.1002 $[\mathrm{M}+\mathrm{Na}]^{+}$means the theoretical mass was in complete accord with the experimental value of the corresponding compound

The $\beta$-keto sulfone analogues of cytosine nucleosides (58-59) were treated with different electrophiles and these electrophiles were efficiently trapped at the $\alpha$-carbon of the corresponding keto sulfone analogues with high yield. Thus treatment of $\beta$-keto sulfone analogue 58 with benzyl bromide in the presence of dil. $\mathrm{NaOH}$, the $\alpha$-benzylated product $\mathbf{6 0}$ was obtained as a 52/48 mixture of diastereomers with $68 \%$ yield. Interestingly, no dibenzylation at the $\alpha$-carbon was observed (Scheme 59).
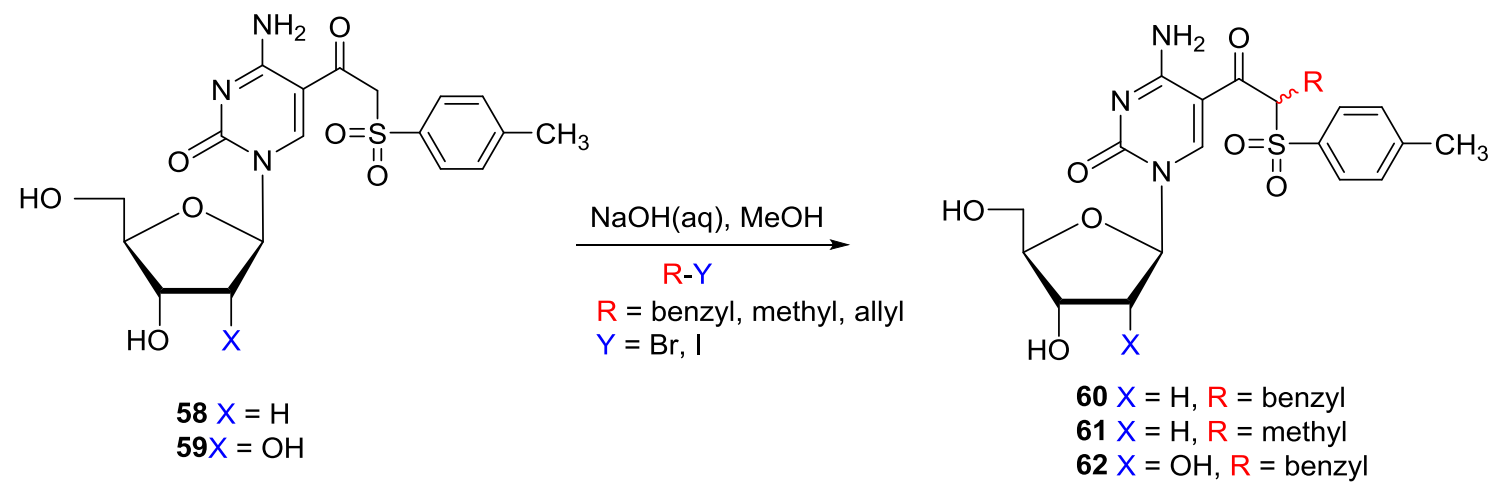

Scheme 58. Synthesis of 5-( $\alpha$-subsitituted $\beta$-keto sulfone) of cytidine and 2-deoxycytidine The structure of the benzylated product $\mathbf{6 0}$ was established by applying different NMR techniques. In ${ }^{1} \mathrm{H}$ NMR two multiplets of $\alpha$-proton was observed at 5.45-5.52 and 5.55-5.62 ppm. In addition methylene proton of benzyl group was found at 3.30-3.40 ppm as a multiplet. Aromatic proton of benzyl group was observed at 7.05-7.25 ppm. In ${ }^{13} \mathrm{C}$ NMR $\alpha$-carbon peak was obtained at $69.0 \mathrm{ppm}$. The methylene carbon peak of benzyl group was observed at 32.0 
ppm and the aromatic peaks were collapsed with the tosyl peaks in the region between 127.0 ppm to $130.0 \mathrm{ppm}$.

Analogues treatment of $\mathbf{5 9}$ with benzyl bromide in the presence of dil. $\mathrm{NaOH}$ afforded $\alpha-$ benzylated product 61 with $67 \%$ yield (Scheme 59). Benzyl disubtitution at $\alpha$-carbon was not observed. In ${ }^{1} \mathrm{H}$ NMR of 61, $\alpha$-proton peak was appeared at 5.60-5.70 ppm as a multiplet. The methylene peak of benzyl group was observed at 3.18-3.30 ppm as a multiplet. The aromatic peaks were appeared at7.10-7.25 ppm. In ${ }^{13} \mathrm{C}$ NMR the $\alpha$-carbon peak was appeared at 70.0 ppm. The methlene carbon peak of benzyl group was found at $31.0 \mathrm{ppm}$. Aromatic peak of the benzyl group was observed at the region from 126.0 to $129.0 \mathrm{ppm}$ which collapsed with the tosyl peaks.

Treatment of compound $\mathbf{5 8}$ with methyl iodine in basic medium gave 52/48 mixture of diastereomers 62 with $68 \%$ yield (Scheme 59). As usual no dimethylation observed at the $\alpha$ carbon. Analogue 62 was characterized by applying different NMR techniques. In ${ }^{1} \mathrm{H}$ NMR $\alpha-$ proton peak was observed at 5.20-5.30 ppm. The methyl proton was appeared at 1.32-1.38 ppm. In ${ }^{13} \mathrm{C}$ NMR peaks of $\alpha$-carbon and methyl group were found at $64.0 \mathrm{ppm}$ and $12.0 \mathrm{ppm}$ respectively.

\subsection{Incorporation of ( $\beta$-halo)vinyl sulfone probes at 8-position of 2 '-deoxyadenosine}

The $\beta$-halo sulfonylation reaction was also extended into the purine nucleosides by the reaction of terminal alkyne group via halosulfonylation reactions. Thus the acetylene group was incorporated at the 8 position of the 2'-deoxyadenosine analogue following the literature

procedure $^{117,118}$ which involved TBDS protection at the sugar moiety, bromination at 8 position, Sonogashira coupling, and silyl deprotection as depicted in Scheme 60. 


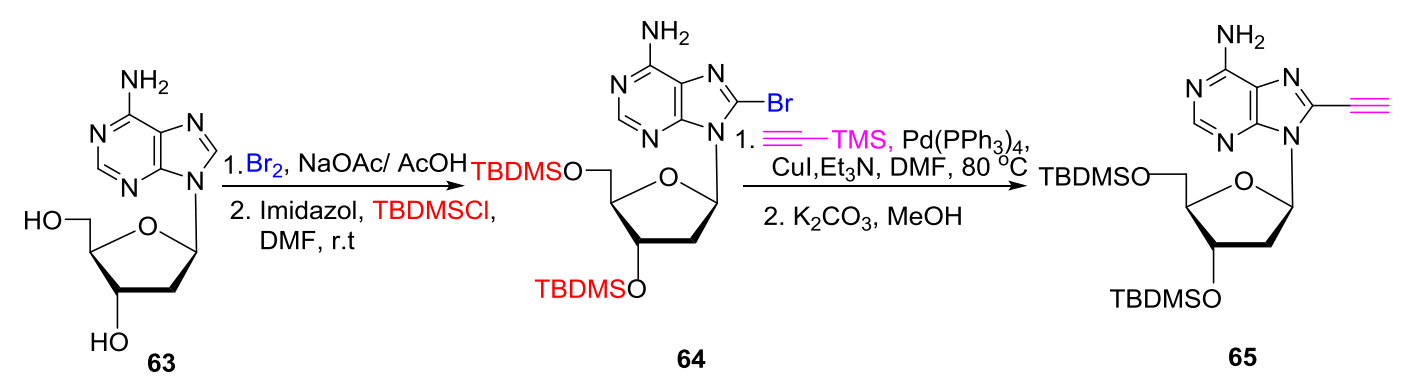

Scheme 59. Synthesis of protected 8-acetylene 2'-deoxyadenosine

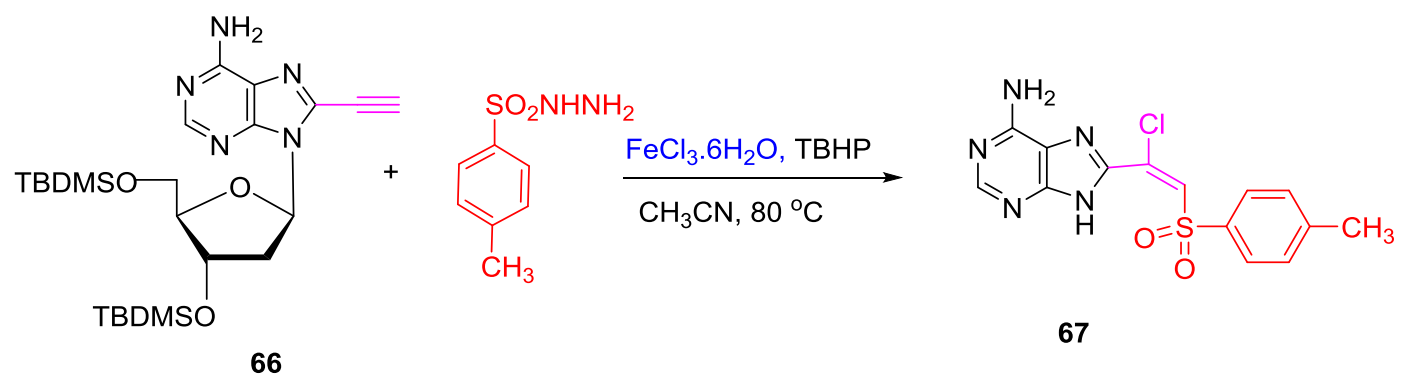

Scheme 60. Attempted halosulfonylation of 8-ethynyl -2'-deoxyadenine 23 with tosyl hydrazide. Synthesis of 8-(1-chloro-2-tosylvinyl)adenine

Treatment of 2'-deoxy-3',5'-bis( $O$-tert-butyldimethylsilyl)-8-ethynyl adenosine $\mathbf{6 6}$ with tosyl hydrazide gave 8-(1-chloro-2-tosylvinyl)adenine (67) with the yields of 44\% (Scheme 61). In this halosulfonylation reaction the cleavage of $\beta$-glycosidic took place which was confirmed from the proton NMR as there was no peak of the sugar moiety observed. In aditio there was a peak of the NH proton observed at $13.5 \mathrm{ppm}$. The vinyl peak was observed at 7.90 ppm. The three tosyl peaks were appeared at 2.40, 7.45, and $7.80 \mathrm{ppm}$. In the carbon NMR of 67, vinyl peak was detected at $136.4 \mathrm{ppm}$ while the $\mathrm{C}-\mathrm{Cl}$ peaks appeared at $143.0 \mathrm{ppm}$. The five tosyl peaks were found at 21.0, 128.0, 130.0, 135.0, and $145.0 \mathrm{ppm}$. 


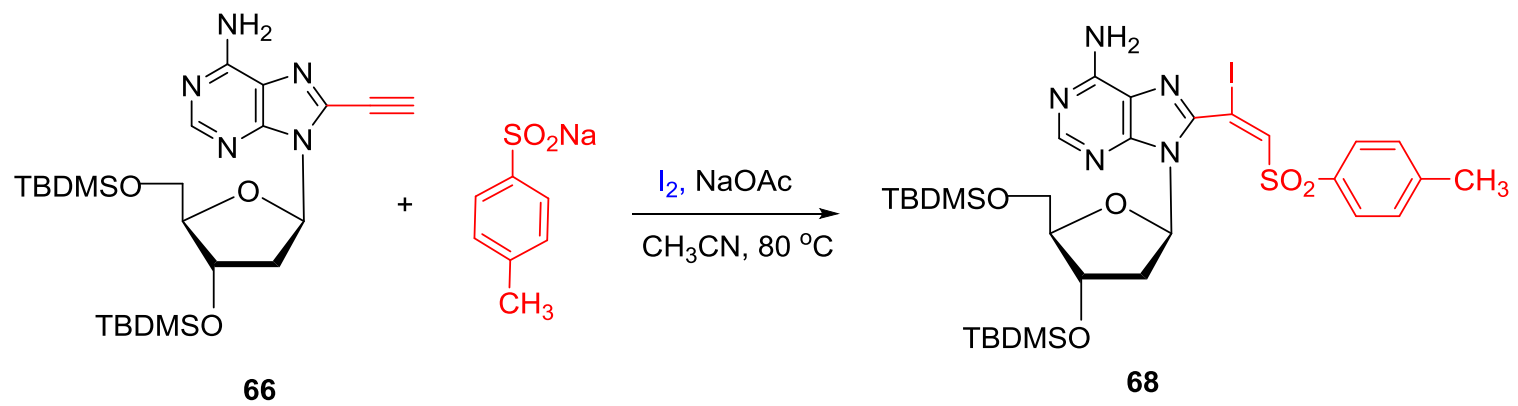

Scheme 61. Synthesis of 8-( $\beta$-iodovinyl)sulfone analogue of 2'-deoxyadenosine

Interestingly when silyl protected 8-ethynyl adenosine analogue 66 is reacted with sodium salt of p-toluenesulfinic acid and iodine, no glycosidic bond cleavage was observed. Thus, treatment of $\mathbf{6 6}$ with sodium tosylate and iodine in the presence of sodium acetate afforded 8( $\beta$-iodovinyl)sulfone of silyl protected 2'-deoxyadenosine analogue 68 with $48 \%$ yield (Scheme 62). In the proton NMR of $\mathbf{6 8}$ the vinyl peak was observed at $7.60 \mathrm{ppm}$. The three tosyl peaks were appeared at 2.40, 7.25, and $7.70 \mathrm{ppm}$. In the carbon NMR of the vinyl peak was detected at $136.0 \mathrm{ppm}$ while the C-I peaks appeared at $129.0 \mathrm{ppm}$. The C_H peaks from tosyl group were converged at $130.0 \mathrm{ppm}$. The successful conversion of 8-ethylnyl-2'deoxyadenosine $\mathbf{6 6}$ to 8 -( $\beta$-iodovinyl)sulfone of 2'-deoxyadenosine $\mathbf{6 8}$ showed that halovinylsulfonylation can be extended to the purine nucleoside analogues.

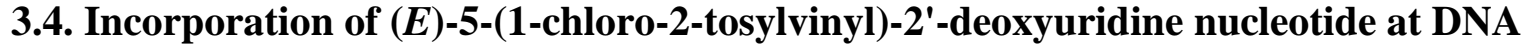

\subsubsection{Synthesis of $5^{\prime}$-phosphates}

Phosphorylation is an important technique to study important biological properties of the nucleotides in living cell. Phosphorylation at 5 ' position of the 2'-deoxynecloside analogues are widely useful technique to DNA polymerase mediated incorporation in DNA. Here novel 5-(1-chloro-2-tosylvinyl)-2'-deoxyuridine analogues have been triphosphorylated at 5'position in order to polymerase mediated incorporation in DNA and to study the DNA-protein 
interaction by reacting with protein molecules. Phosphorylation was accomplished by applying modified Yoshikawa method. ${ }^{119}$
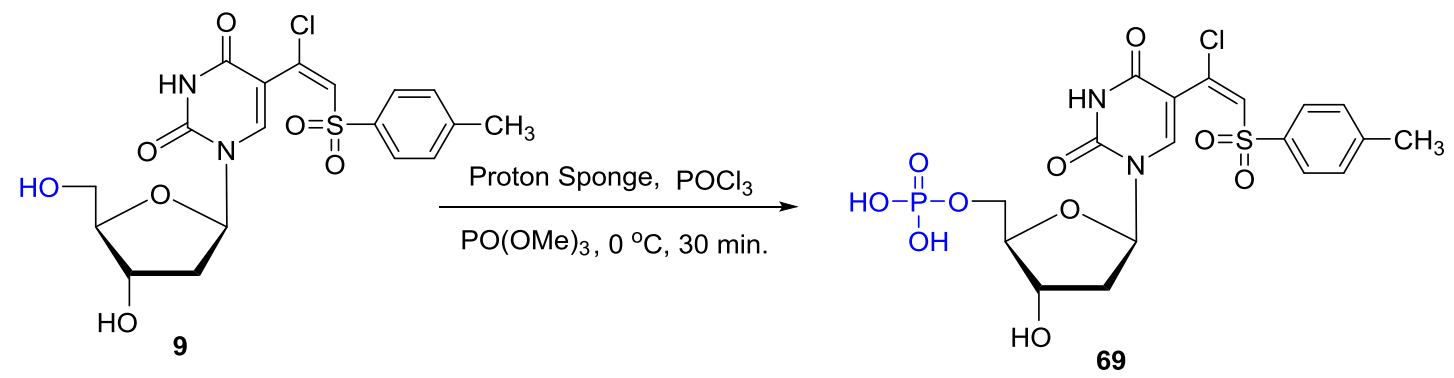

Scheme 62. Synthesis of 5'-monophosphate of 5-( $\beta$-chlorovinyl sulfone) of 2'deoxyuridine by modified Yoshikawa method

Treatment of $\beta$-chlorovinyl sulfone analogue 9 with 1.8 equiv. of phosphoryl chloride in the presence of 2.0 equiv. of proton sponge in trimethyl phosphate solvent at $0{ }^{\circ} \mathrm{C}$ gave 5 dichlorophosphate intermediate $\mathbf{7 0}$ in very good yield ( 70\%; TLC). Subsequent treatment of intermediate 70 with 4.2 equiv. of tributylammonium pyrophosphate (TBAPP) and 2.7 equiv. of tributylamine (TBA) at $\mathrm{rt}$ afforded 5'-triphosphorylated analogue $\mathbf{7 1}$ in moderate yield (32\%) as depicted in Scheme 64. Alternatively, the intermediate $\mathbf{7 0}$ have been efficiently converted into 5'-monophosphate $\mathbf{6 9}$ by quenching the reaction with TEAB buffer. 


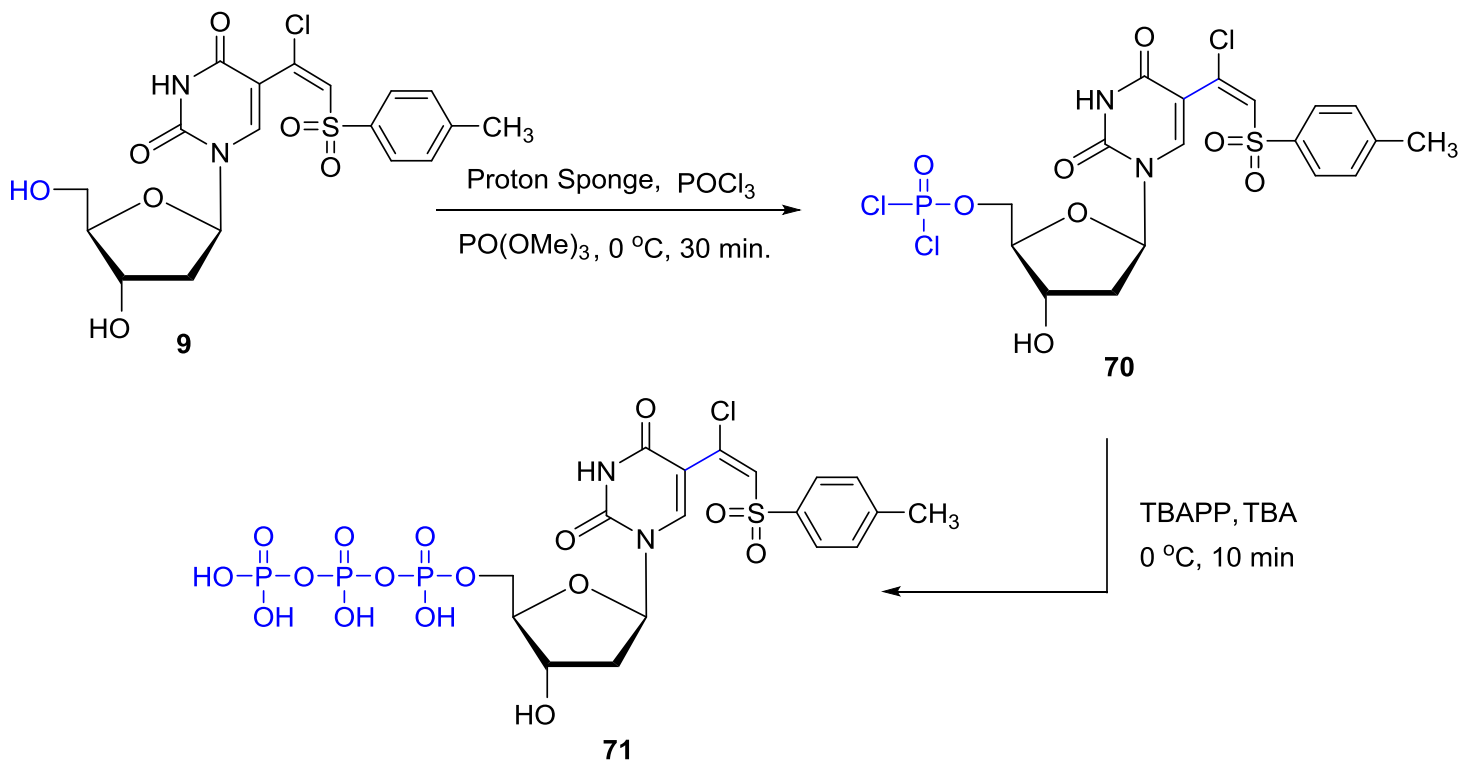

Scheme 63. Synthesis of 5'-triphosphate of 5-(1-chloro-2-tosylvinyl)-2'-deoxyuridine

The 5'-triphosphosphate $\mathbf{7 1}$ was characterized by applying different NMR techniques such as ${ }^{31} \mathrm{P},{ }^{1} \mathrm{H}, \mathrm{COSY}, \mathrm{HMQC}$, DEPT-135, ${ }^{13} \mathrm{C}$; and FT-ICR mass spectrometry. In phosphorous NMR three peaks were observed at $\delta-23(\beta-\mathrm{P}),-11.5(\alpha-\mathrm{P}),-10.5(\gamma-\mathrm{P})$. The peaks at -23.0 ppm confirmed that triphophorylation had been taken place as $\beta$-phosphorous atom of triphosphorylated compound gave peak at around $-23.0 \mathrm{ppm}$. The chlorine atom of $\beta$ chlorovnyl sulfone analogue was readily substituted by nucleophile through additionelimination type reaction. So, it was a concern whether the chlrorine survived at that basic condition after triphosphorylation reaction. However, the mass spectrum showed the presence of chloride as it has a classic isotopic pattern at the molecular ion peak and the peak intensity is 3:1. The observed molecular mass was $680.95172[\mathrm{M}-\mathrm{H}]^{-}$which was in very good agreement with the theoretical mass of the compound $680.95186 \mathrm{ppm}$ and the mass error was 
only $0.2 \mathrm{ppm}$. All the proton and carbon peaks were assigned by analyzing different NMR spectrum and all the values were in accordance with the expected values.

\subsubsection{DNA polymerase catalyzed incorporation into DNA}

To study the bioconjugation of the novel ( $\beta$-chloro)vinyl sulfone analogue with proteins in vivo, it is indispensable to incorporate this novel probe into DNA. The phosphorylated $(\beta$ chloro)vinyl sulfone analogue 71 was incorporated into double strand DNA by using DNA polymerase where the extent of incorporation was tested both in DNA leading and lagging strand by using bacterial replication DNA polymerase, the Klenow fragment of DNA polymerase I (pol I) and human repair DNA polymerase, DNA polymerase $\beta$ (pol $\beta$ ). The concentration of the DNA pol I (pol I) was $5 \mathrm{U}$ in each time, however different concentrations of DNA polymerase $\beta$ (pol $\beta$ ) such as $0.5 \mathrm{nM}, 1 \mathrm{nM}, 5 \mathrm{nM}, 10 \mathrm{nM}, 25 \mathrm{nM}$, and $50 \mathrm{nM}$ were used. The concentration of the $(\beta$-chloro)vinyl sulfone analogue 71 was $50 \mu \mathrm{M}$. The polymerase mediated DNA incorporation was monitored by applying polyacrylamide gel electrophoresis (PAGE) technique. The details of nucleotide sequence and number, primer, and template are tabulated below:

Table 3. Detailed information of nucleotides used during polymerase mediated incorporation

\begin{tabular}{|c|c|c|}
\hline Nucleotide & nt & Sequence (5'-3') \\
\hline Upstream primer & 31 & $\begin{array}{c}\text { GCA GTC CTC TAG TCG TAG TAG CAG } \\
\text { ATC ATC A }\end{array}$ \\
\hline \# Downstream primer & 39 & $\begin{array}{c}\text { CAA CCG GCA TTA GGT GTA GTA GCT } \\
\text { AGA CTT ACT CAT TGC }\end{array}$ \\
\hline Template & 71 & $\begin{array}{l}\text { GCA ATG AGT AAG TCT AGC TAC TAC } \\
\text { ACC TAA TGC CGG TTG ATG ATG ATC } \\
\text { TGC TAC TAC GAC TAG AGG ACT GC }\end{array}$ \\
\hline
\end{tabular}




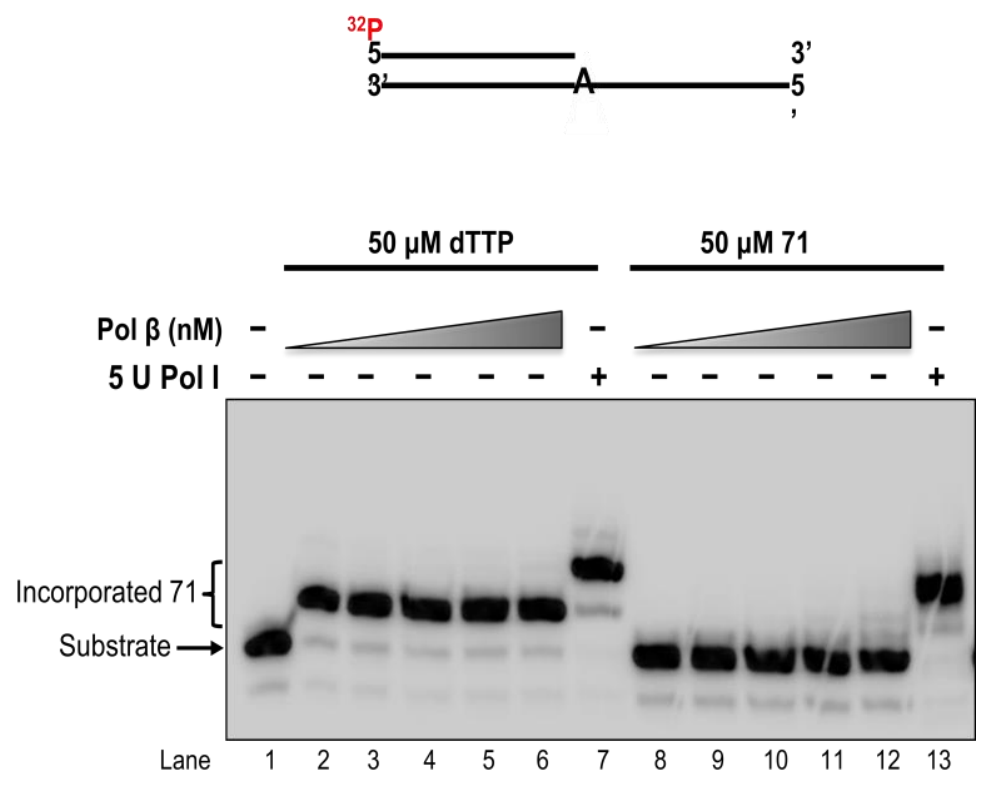

Figure 15. Incorporation of ( $\beta$-chloro)vinyl sulfone analogue into DNA open template by DNA polymerase

During the polymerase mediated incorporation approach of the substrate $\mathbf{7 1}$ in DNA open template which leads to DNA synthesis, human repair DNA polymerase (pol $\beta$ ) was unable to incorporate the substrate into DNA at any of the concentration mention above (Fig.15, Lane 8-12). However, bacterial polymerase pol I can efficiently incorporated the substate (Figure 15, Lane 13) at $5 \mathrm{U}$ concentrations like the natural substrate deoxythymidine triphosphate (dTTP). However due to the excessive activities of the pol I on the substrate one more unit of the substrate $\mathbf{7 1}$ incorporated and thus mismatch happened which was obvious in PAGE analysis (Figure 15, Lane13). 


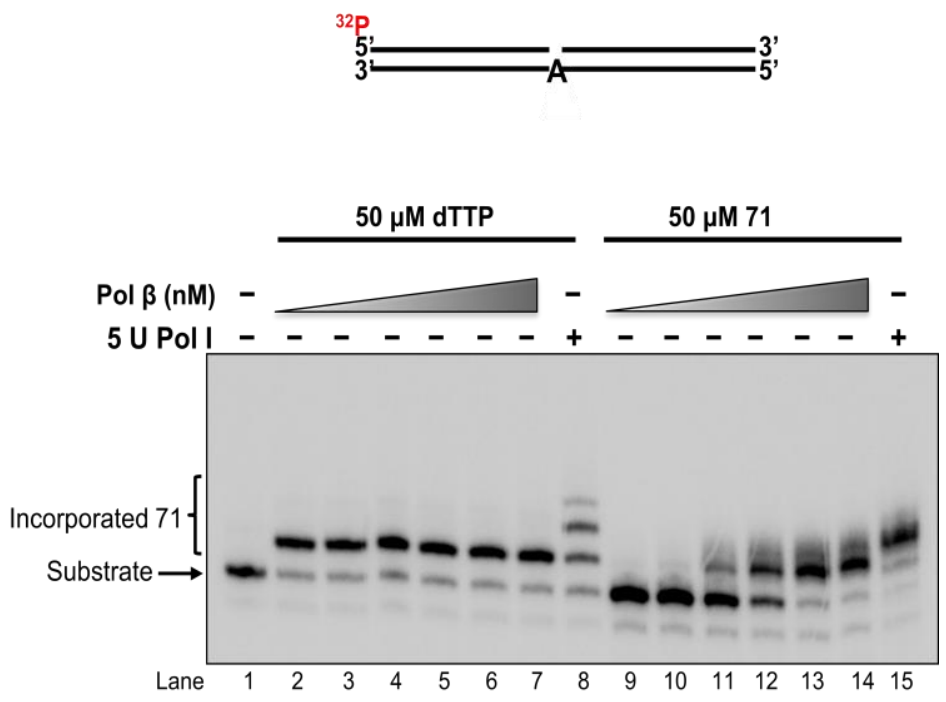

Figure 16. Incorporation of ( $\beta$-chloro)vinyl sulfone analogue into DNA one gap nucleotide template by DNA polymerase

During the polymerase mediated incorporation of the substrate into the one gap nucleotide template of DNA which causes lagging during the DNA synthesis, both human repair DNA polymerase (pol $\beta$ ) and bacterial polymerase (pol I) efficiently incorporated the chlorovinyl substrate 71 (Figure 16, Lane 13-15). However, human repair DNA polymerase (pol $\beta$ ) mediated incorporation of the substrate is dependent on the concentration of the polymerase. From the PAGE analysis it was obvious that 0.1 and $0.5 \mathrm{nM}$ concentration of pol $\beta$ couldn't incorporate the substrate 58 (Figure 16, Lane 8-9). However, at $1.0 \mathrm{~nm}$ concentration of pol $\beta$ the incorporation was observed (Figure 16, Lane 10), though the extent of incorporation was low at that concentration. With the increase of the concentration of the pol $\beta$ the extent of incorporation enhanced significantly. When $25.0 \mathrm{nM}$ pol $\beta$ was used the polymerase incorporated the substrate $\mathbf{7 1}$ (Lane 13) as like the natural substrate dTTP (Lane 6). Similar to the open template, $5 \mathrm{U}$ concentration of pol I efficiently incorporated the substrated at the template with the mismatched (one more unit incorporated) (Figure 16, Lane 15). 


\subsubsection{Conjugation of phosphorylated chlorovinyl sulfone analogue with L-glutathione}

Treatment of monophosphorylated ( $\beta$-chloro)vinyl sulfone 69 with L-glutathione in the presence of triethyl amine in methanol-water mixed solvent system gave the bioconjugated product 72 with 55\% yield (Scheme 65).

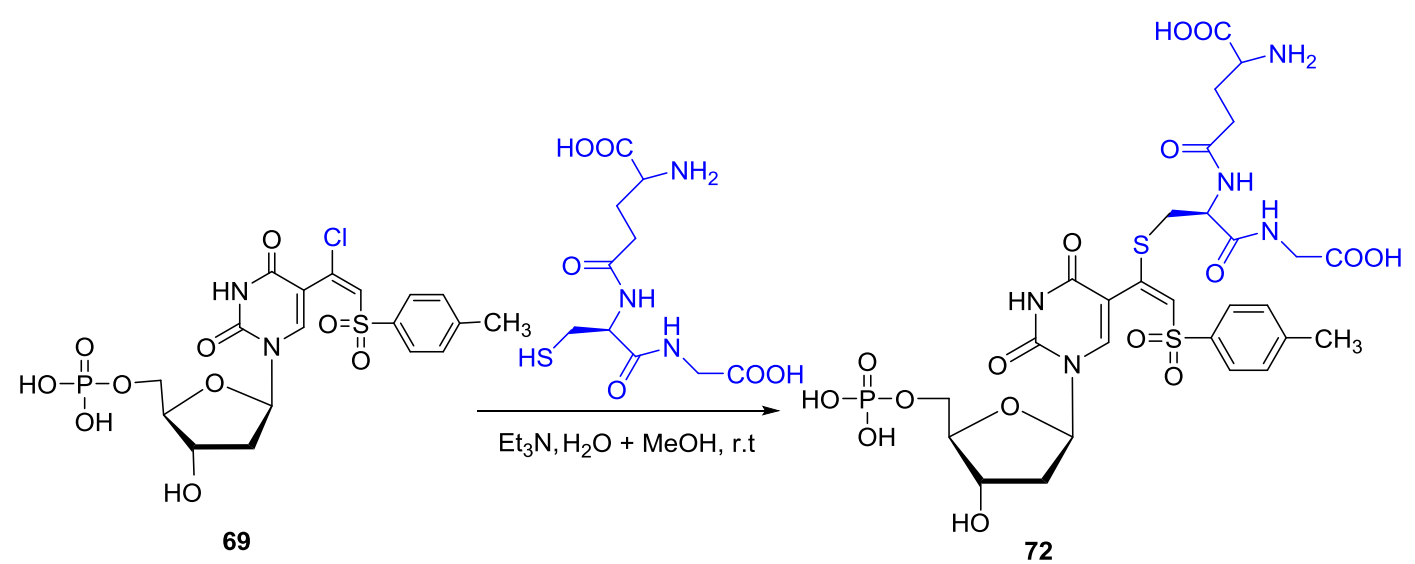

Scheme 64. Conjugation of 5-( $\beta$-chlorovinyl sulfone) of 2'-deoxyuridine-5'monophosphate with L-glutathione

The structure of the bioconjugated analogue $\mathbf{7 2}$ was determined by applying different NMR techniques and experimental mass value was obtained from FT-ICR mass spectrometry where the ionization was carried out in the negative mood.

In the proton NMR distinct peaks of glutathione were observed in the region from 2.0 to $5.0 \mathrm{ppm}$. The three amino acids peak of glutathione which are cysteine, glutamic acid and glycine were appeared in that region. It was difficult to figure out the multiplicity of some of the proton peaks due to the peak overlapping with the sugar moieties of the nucleosides. In carbon NMR the four carbonyl carbon peaks of the amide and carboxylic acid groups were observed at 171.0, 175.0, 177.0, and $177.0 \mathrm{ppm}$. The other six carbon peaks were appeared from 25.0 to $65.0 \mathrm{ppm}$. Finally the experimental mass value which was similar with the theoretical value confirmed the presence of $\mathbf{7 2}$. 


\subsection{Incorporation of 5-(2-tosylacetyl)-2'-deoxyuridine nucleotide at DNA}

\subsubsection{5'- Phosphorylation}

Novel 5-(2-tosylacetyl)-2'-deoxyuridine analogues have been triphosphorylated at 5'position in order to polymerase mediated incorporation in DNA and to study the DNA-protein interaction by reacting with protein molecules. Phosphorylation was accomplished by applying modified Yoshikawa method. Treatment of $\beta$-keto analogue 51 with 1.7 equiv. of phosphoryl chloride in the presence of 2.0 equiv. of proton sponge in trimethyl phosphate solvent gave 5'-dichlorophosphate intermediate compound $\mathbf{7 3}$ in very good yield ( 70\%; TLC). Subsequent treatment of 5'-monophosphorylated intermediate 73 with 4.1 equiv. of tributylammonium pyrophosphate (TBAPP) and 2.5 equiv. of tributyl amine (TBA) gave 5'triphosphorylated analogue $\mathbf{7 4}$ in moderate yield (38\%) as depicted in Scheme 66.
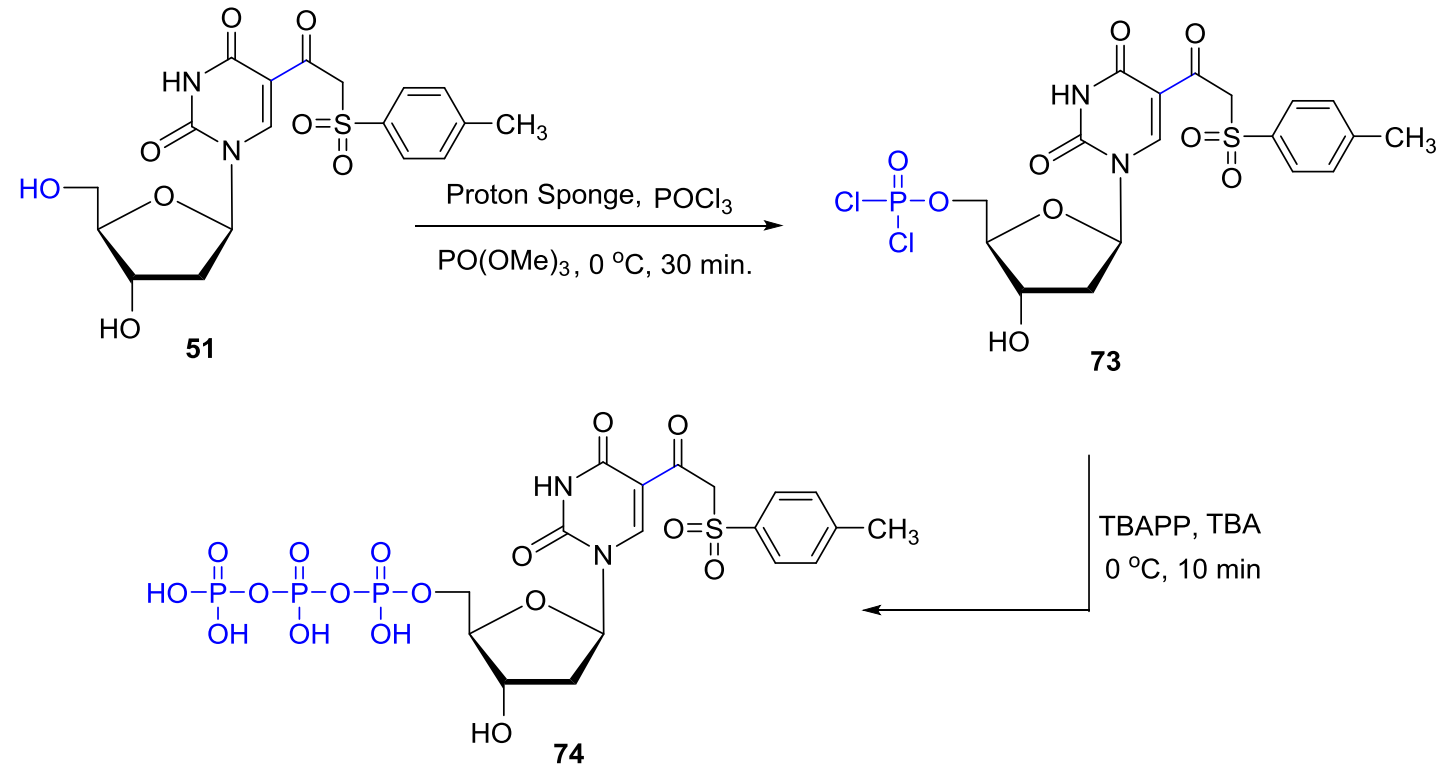

Scheme 65. 5'-Phosphorylation of 5-(2-tosylacetyl)-2'-deoxyurindine

The 5'-triphosphate 74 was characterized by applying different NMR techniques such as

${ }^{31} \mathrm{P},{ }^{1} \mathrm{H}, \mathrm{COSY}, \mathrm{HMQC}$, DEPT-135, ${ }^{13} \mathrm{C}$; and FT-ICR mass spectrometry. In phosphorous 
NMR three peaks were observed at $-23.5,-11.7,-11.0 \mathrm{ppm}$. The peaks at $-23.5 \mathrm{ppm}$ confirmed that triphophorylation had been taken place as $\beta$-phosphorous atom of triphosphorylated compound gave peak at around $-23.0 \mathrm{ppm}$. It was a concerned whether the acidic $\alpha$-methylene proton survived at that basic condition. However, the presence of proton peak at $4.20 \mathrm{ppm}$ and integration value indicated the survival of the $\alpha$-methylene proton. In addition in DEPT-135 NMR $\alpha-\mathrm{CH}_{2}$ peak was observed at $67.0 \mathrm{ppm}$ which also ensured the presence of unaffected $\alpha$-methylene group. Finally the mass of the compound was determined by ultra high resolution mass spectroscopy in negative mood. The experimental value of the compound 72 was $662.98595[\mathrm{M}-\mathrm{H}]^{-}$compared to the theoretical value $662.98575[\mathrm{M}-\mathrm{H}]^{-}$ with a mass error of only $0.3 \mathrm{ppm}$.

\subsubsection{Incorporation into DNA by DNA polymerase}

Both human DNA repair polymerase (pol $\beta$ ) and bacterial polymerase (pol I) efficiently incorporated $\beta$-keto sulfone analogue 74 into DNA open template. At 5 U concentration pol I efficiently incorporated the substrate $\mathbf{7 4}$ like the natural substrate dTTP. However, the human DNA repair polymerase $\beta$ mediated incorporation was dependent on the concentration of the polymerase (Figure 17) 


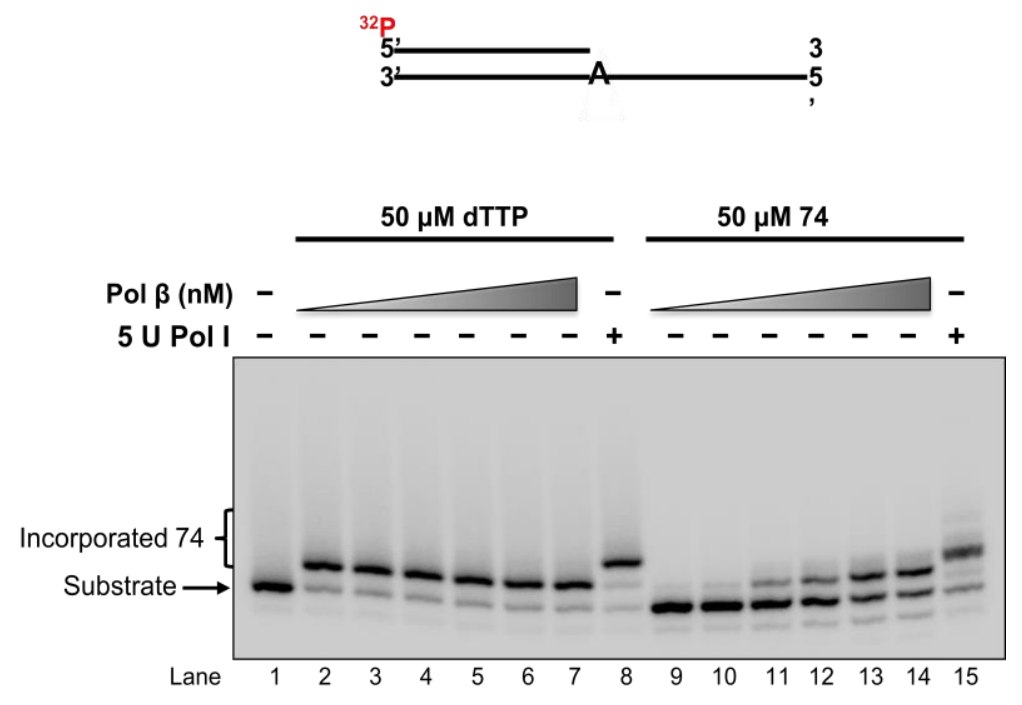

Figure 17. Incorporation of 5 ( $\beta$-keto)sulfone analogue into DNA open template by DNA polymerase

Incorporation started to take place at $1.0 \mathrm{nM}$ polymerase concentration and at $25.0 \mathrm{nM}$ pol $\beta$ the incorporation was about 50\% (Figure 17, Lane 13) which increased to about $70 \%$ at 50.0 $\mathrm{nM}$ concentration of the polymerase $\beta$.

Polymerase mediated incorporation of the ( $\beta$-keto)sulfone analogue $\mathbf{7 4}$ into one nucleotide gap template was observed when either of the polymerase was used. $5 \mathrm{U}$ concentration of the bacterial polymerase (pol I) efficaciously incorporated the ( $\beta$-keto)sulfone analogue 74 (Figure 18, Lane 15). In this nucleotide template enhance activities of the human repair DNA polymerase ( $\mathrm{pol} \beta$ ) was observed. Even at $0.1 \mathrm{nM}$ of this polymerase incorporated about $50 \%$ of the ( $\beta$-keto)sulfone analogue 72 (Figure 18, Lane 9) and only $1.0 \mathrm{nM}$ pol $\beta$ incorporated the substrate 74 (Figure 18, Lane 11) like the natural substrate dTTP (Figure 18, Lane 4). 


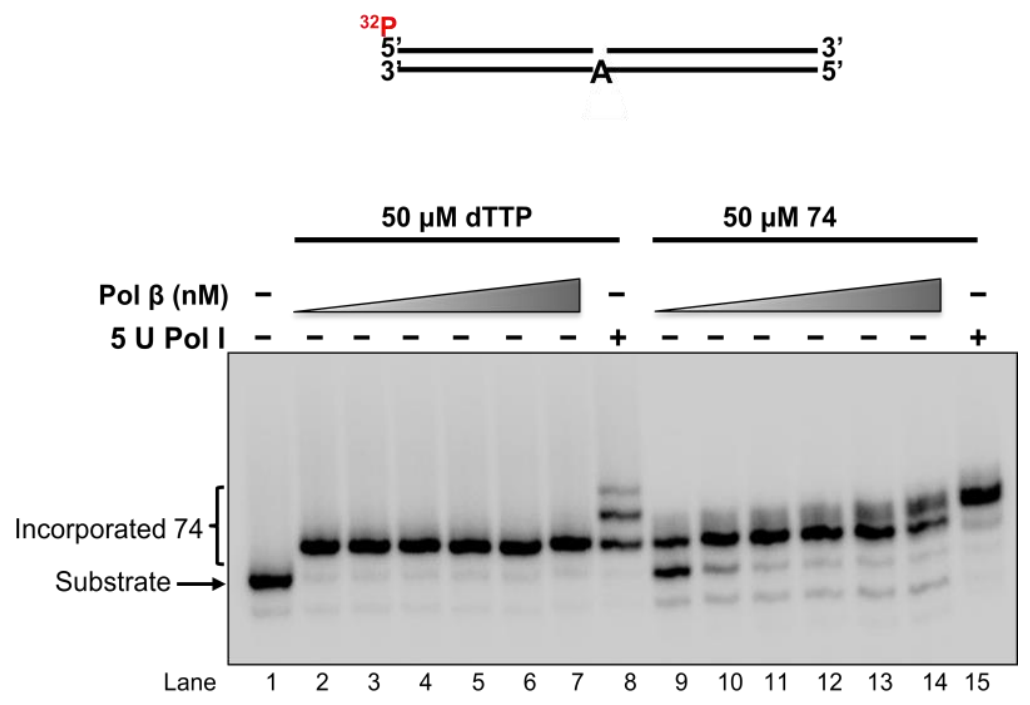

Figure 18. Incorporation of ( $\beta$-keto)sulfone analogue into DNA one nucleotide gap template by DNA polymerase

\subsection{Prodrugs of C5 modified uracil nucleosides}

A number of C5-modified uracil nucleoside analogues has been synthesized in our lab ${ }^{90}$ and their anticancer and antiviral activities were tested at Rega Institute for Medical Iesearch in Belgium. Interestingly, it has been observed that the half maximal inhibitory concentration $\left(\mathrm{IC}_{50}\right)$ of the acetyl protected chlorovinyl sulofne analogue 9a against the proliferation of murine leukemia cells (L1210) were much lower as compared to its unprotected chlorovinyl sulfone counterpart $9(5.6 \pm 4.7 \mu \mathrm{M}$ vs. $>200 \mu \mathrm{M})$. Therefore, based on these findings liphophilic long alkyl chain was incorporated at the 5' and/or 3' position of at 5-modified analogue 9 and a number of 5-arylated analogues via esterification reaction. 


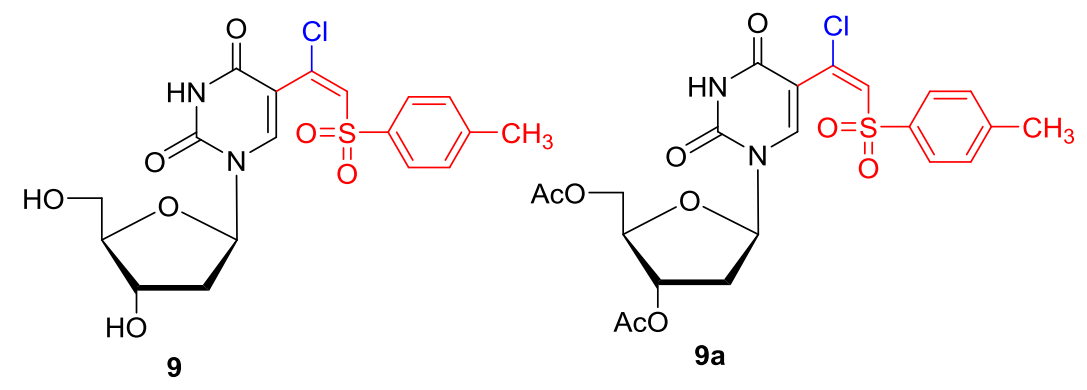

Figure 19. Lipophobic (9) and lipophilic (9a) 5-modified-2' deoxynucleoside analogues

\subsubsection{Synthesis of prodrug of $(E)$-5-(1-chloro-2-tosylvinyl)-2'-deoxyuridine}

To incorporate more liphophilic long alkyl chain at the sugar moiety of the nucleoside analogues more reactive undecanoic anhydride was prepared from undecanoic acid. Thus treatment of undecanoic acid with thionyl chloride at ambient temperature for $5 \mathrm{~h}$ gave undecanoyl chloride with quantitative yield.

Treatment of undecanoyl chloride with undecanoic acid in the presence of triethylamine gave undecanoic anhydride with quantitative yield.

$$
\mathrm{C}_{10} \mathrm{H}_{21} \mathrm{COOH} \underset{\mathrm{CH}_{2} \mathrm{Cl}_{2}, \mathrm{r.t}}{\stackrel{\mathrm{SOCl}_{2}}{\longrightarrow}} \mathrm{C}_{10} \mathrm{H}_{21} \mathrm{COCl} \underset{\mathrm{Et}_{3} \mathrm{~N}, \mathrm{CH}_{2} \mathrm{Cl}_{2}, \mathrm{r} . \mathrm{t}}{\stackrel{\mathrm{C}_{10} \mathrm{H}_{21} \mathrm{COOH}}{\longrightarrow}}\left(\mathrm{C}_{20} \mathrm{H}_{42} \mathrm{CO}\right)_{2} \mathrm{O}
$$

Scheme 66. Preparation of undecanoic anhydride from undecanoic acid

Further treatment of undecanoyl chloride with undecanoic acid for overnight and evaporation of volatiles under reduced pressure gave undecanoic anhydride as white solid with quantitative yield (Scheme 67).

Treatment of $\beta$-chloro vinyl sulfone analogue 9 with undecanoic anhydride gave mono and diprotected products from moderate to good yield. When $\beta$-chloro vinyl sulfone analogue 9 was treated with 1.2 equiv. of undecanoic anhydride for two hours, the major product was (E)-5'-O-undecanoyl-5-(1-chloro-2-tosylvinyl)-2'-deoxyuridine $\quad(\mathbf{7 5}) \quad$ with $\quad 45 \%$ yield. 
However, treatment of $\beta$-chloro vinyl sulfone analogue 9 with 3 equiv.of undecanoic anhydride for $6 \mathrm{~h}$ gave (E)-3',5'-Di- $O$-undecanoyl-5-(1-chloro-2-tosylvinyl)-2'-deoxyuridine (76) as major product with $75 \%$ yield (Scheme 68 ). Also small quantities of 3'-O-undecanoyl product was isolated (see Experimental Part).
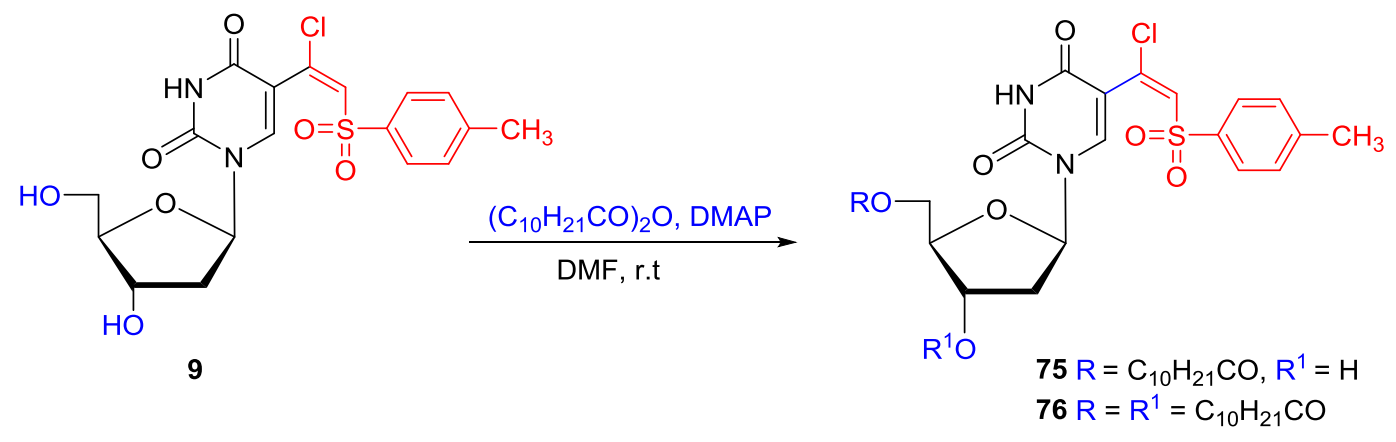

Scheme 67. Synthesis of undecanoate protected 5-(1-chloro-2-tosyl)vinyl-2'-deoxyuridine

Both mono and di-protected compounds $\mathbf{7 5}$ and $\mathbf{7 6}$ were characterized by applying NMR techniques i.e ${ }^{1} \mathrm{H}, \mathrm{COSY}, \mathrm{HMQC}$, DEPT-135, ${ }^{13} \mathrm{C}$ and mass of the products were determined by high resolution mass spectrometry. The proton NMR peak at $0.88,1.24-1.39,1.62$, and $2.34 \mathrm{ppm}$ and integration value of number of proton confirmed the presence of one undecanoyl group in the sugar moiety. The higher chemical shift value of H5' proton at 4.40 ppm while almost unchanged chemical shift value of $\mathrm{H}^{\prime}$ proton which is at $4.17 \mathrm{ppm}$ indicated that esterification took place at 5'-OH group. In addition, the presence of 3'-OH at $3.00 \mathrm{ppm}$ further justified the regioselective esterification of 9. Eleven carbon peaks at 14.2, 22.0, 25.0 29.2, 29.4, 29.5, 29.7, 29.8, 32.2, 34.4, and $174.0 \mathrm{ppm}$ in compound $\mathbf{7 5}$ indicated the presence of one undecanoyl group. Finally, experimental mass value of 633.2013 $[\mathrm{M}+\mathrm{Na}]^{+}$confirmed the presence of mono protected analogue $\mathbf{7 5}$.

The integration values of different proton peaks at the region from 0.84 to $2.34 \mathrm{ppm}$ and higher chemical shift values of H3' and $\mathrm{H}^{\prime}$ at $4.42 \mathrm{ppm}$ and $5.27 \mathrm{ppm}$ indicated the presence 
of diprotected compound. In addition the different carbon peaks and experimental mass value 801.3505 $[\mathrm{M}+\mathrm{Na}]^{+}$confirmed the diprotected compound $\mathbf{7 6}$.

\subsubsection{Synthesis of prodrug of 5-(fur-2-yl/5-heptylfur-2-yl)-2'-deoxyuridine}

The 5-(fur-2-yl)-2'-deoxyuridines $\mathbf{7 8}$ and $\mathbf{8 0}$ have been synthesized from 5-iodo substrates $\mathbf{2}$ and $\mathbf{7 7}$ following the literature procedure. ${ }^{91}$ Analogously, tetrabutylammonium fluoride (TBAF)-mediated direct $\mathrm{C}-\mathrm{H}$ arylation of 5-iodouracil nucleosides 2 and 77 with 2heptylfuran provided 5-(heptylfur-2-yl)-2'-deoxyuridine $\mathbf{7 9}$ and 8 . $^{120}$ Treatment of unprotected derivatives $\mathbf{8 0}$ or $\mathbf{8 1}$ with undecanoic anhydride gave mono and diacylated products from moderate to good yield. Thus, treatment of 5-(fur-2-yl) 80 or 5-(5-heptylfur-2yl) 81 analogues with 1.2 equiv. of undecanoic anhydride for two hours afforded 5'- $O$ undecanoyl-5-(fur-2-yl)-2'-deoxyuridine (82) or 5'-O-undecanoyl-5-(5-heptylfur-2-yl)-2'deoxyuridine (84) with the yield of $52 \%$ and $48 \%$ respectively. Analogues treatment of $\mathbf{8 0}$ or 81 with 3 equiv. of undecanoic anhydride for 6 h afforded 3',5'-di- $O$-undecanoyl-5-(fur-2-yl)2'-deoxyuridine (83) or 3',5'-di- $O$-undecanoyl-5-(5-heptylfur-2-yl)-2'-deoxyuridine (85) as major products with the yield of $77 \%$ and $80 \%$ respectively (Scheme 69). Also small quantities of 3'-O-undecanoyl products were isolated (see Experimental Part)

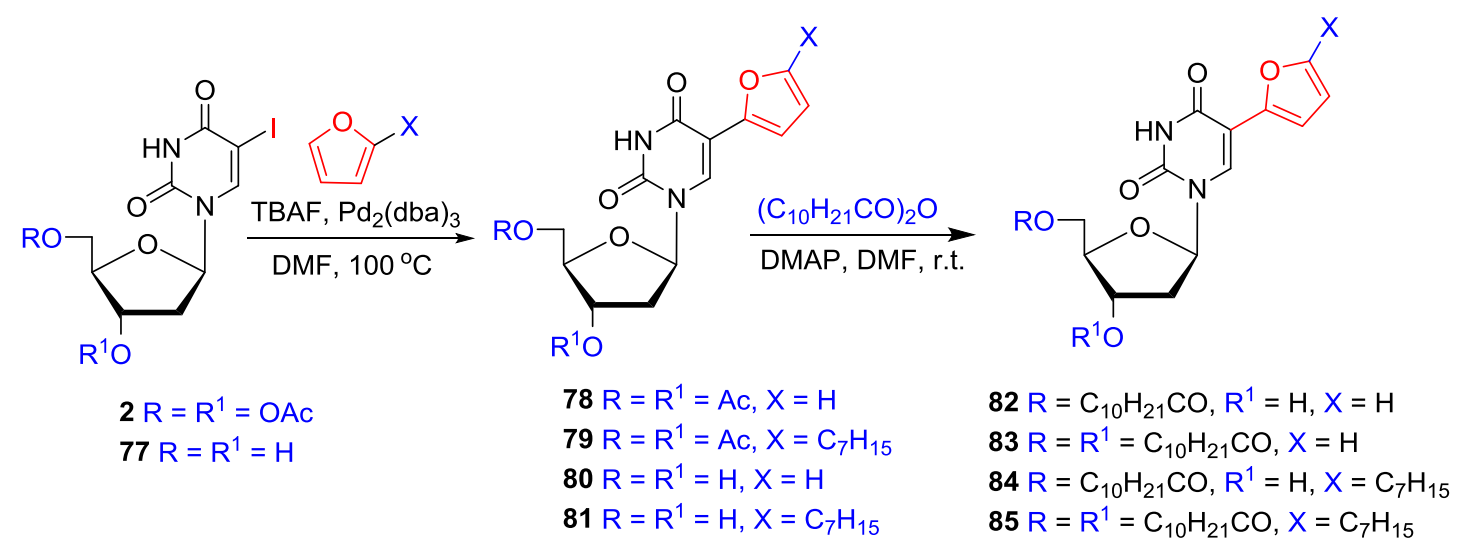

Scheme 68. Synthesis of 5-(fur-2-yl)/5-(heptafur-2-yl)-2'-deoxyuridine by direct arylation and their undecanoate protected analogues 
Both mono and diprotected compounds were characterized by applying NMR techniques and mass values were determined by HRMS. Accumulating the number of proton present in the compound $\mathbf{8 2}$ or 84 , it was confirmed that these are monoprotected compounds. The regioselectivity of the monoesterified products were confirmed by comparing the chemical shift value of $\mathrm{H}^{\prime}$ ' and $\mathrm{H} 5$ ' proton of the products (82 and $\left.\mathbf{8 4}\right)$ with the starting compound ( 63 and 64) respectively. In the mono protected analogues 82 and $\mathbf{8 4}$ the proton peak of H5' is at 4.25 ppm and $4.28 \mathrm{ppm}$ which are significantly higher than the corresponding proton of the unprotected compounds $\mathbf{8 0}$ or $\mathbf{8 1}$. Additionally, the H3' proton peaks were almost unchanged (4.36 ppm and $4.33 \mathrm{ppm}$ respectively) in the monoprotected products ( $\mathbf{8 2}$ and $\mathbf{8 4}$ ) compared to the unprotected ananogues (80 and $\mathbf{8 1}$ ). This could be only possible when acyl protection takes place at 5' $\mathrm{OH}$ group while $3^{\prime} \mathrm{OH}$ group would be unprotected. In addition each of the compound 82 and 84 has one carbon peak at $174.0 \mathrm{ppm}$ which also indicated the presence of mono-esterified products. Finally, the experimental mass value of the products 82 and 84 which are $485.2264[\mathrm{M}+\mathrm{Na}]^{+}$and $583.3359[\mathrm{M}+\mathrm{Na}]^{+}$respectively confirmed the presence of monoprotected products.

The higher chemical shift values of $\mathrm{H}^{\prime}$ and $\mathrm{H} 5$ ' proton at $5.27 \mathrm{ppm}$ and $4.36 \mathrm{ppm}$ respectively suggested the presence of diprotected analogue 83. The integration value of different proton peaks at the region from 0.82 to $2.40 \mathrm{ppm}$ also agreed this claim. Similar finding was observed in diprotected 5-(heptylfur-2-yl) analogue 85. Two different carbonyl carbon peaks and experimental mass value of $653.3778[\mathrm{M}+\mathrm{Na}]^{+}$and $751.4873[\mathrm{M}+\mathrm{Na}]^{+}$ confirmed the synthesis of diprotected 5-arylated analogues 83 and 85 respectively. 


\subsubsection{Selected antiviral and anticancer activities}

All of the uracil nucleoside analogues (Scheme 68 and 69) were sent to our collaborators at Raga Institute for Medical Research in Belgium to test their antiviral and anticancer activities. The antiproliferative activity of all of the compounds $(\mathbf{9}, 9 \mathrm{a}$, and 75-76) was tested in murine leukemia (L1210), human leukemia (CEM), and human cervical carcinoma (HeLa) cells. Only acetyl protected ( $\beta$-halo)vinyl sulfone 9a inhibited the growth of those cells in lower $\mu \mathrm{M}$ range (Table 4). Interestingly, ( $\beta$-halo)vinyl sulfone derivatives with a larger acyl protected group $\mathbf{7 5}$ and $\mathbf{7 6}$ didn't show improved activity. The 5-(fur-2-yl) analogues (78-85) were also tested against those carcinogenic cells and the acetylprotected 5-heptylfur-2-yl)-2'deoxyuridine 79 inhibited the T-lympocyte cells (CEM) in the $\mu \mathrm{M}$ range. Interestingly unprotected 5-(5-heptylfur-2-yl) analogue 81 exhibited improved activity against the same cells. Both acetyl protected analogue $\mathbf{7 9}$ and unprotected analogue $\mathbf{8 1}$ showed moderate activities against the proliferation of murine leukemia cells (L1210) (Table 4). Unprotected 5(fur-2-yl) analogue $\mathbf{8 0}$ is moderately active against human cervix carcinoma cells (HeLa) proliferation (Table 4). 
Table 4. Inhibitory effects on the proliferation of murine leukemia cells (L1210), human Tlymphocyte cells (CEM), and human cervix carcinoma cells (HeLa). ${ }^{120}$

\begin{tabular}{|c|c|c|c|}
\hline \multirow{2}{*}{ Compound } & \multicolumn{3}{|c|}{ IC $_{50}(\mu \mathrm{M})$} \\
\cline { 2 - 4 } & L1210 & CEM & HeLa \\
\hline $\mathbf{9 a}$ & $5.6 \pm 4.7$ & $11 \pm 10$ & $23 \pm 8$ \\
$\mathbf{7 9}$ & $65 \pm 10$ & $36 \pm 3$ & $>100$ \\
$\mathbf{8 0}$ & $>100$ & $>100$ & $32 \pm 1$ \\
$\mathbf{8 1}$ & $48 \pm 6$ & $16 \pm 4$ & $>100$ \\
$\mathbf{8 4}$ & $>100$ & $93 \pm 4$ & $>100$ \\
$\mathbf{8 5}$ & $>100$ & $78 \pm 16$ & $>100$ \\
\hline
\end{tabular}

$\mathrm{IC}_{50}$ is $50 \%$ inhibitory concentration

The 5-( $\beta$-chlorovinyl)sulfone analogues (9, 9a and 76-77) and 5-(fur-2-yl) analogues (7885) were tested against a broad range of DNA and RNA viruses and the human immunodeficiency virus (HIV). The ( $\beta$-chloro)vinyl sulfone 9a showed an $\mathrm{EC}_{50}$ of $4 \mu \mathrm{M}$ for the Oka strain (VZV $\mathrm{TK}^{+}$) and marginal activity against human cytomegalovirus (HCMV) (Table 5). The 3',5'-di-O-acetyl -5-(5-heptylfur-2-yl) (79) and 5-(5-heptylfur-2-yl) (81) derivatives inhibited the replication of HCMV and varicella zoster virus (VZV) bearing a wild-type thymidine kinase $\left(\mathrm{TK}^{+}\right)$with $50 \%$ effective concentrations $\left(\mathrm{EC}_{50}\right)$ in the range of 10-20 $\mu \mathrm{M}$ (Table 5). 5-(Heptylfur-2-yl)-2-deoxyuridine $\mathbf{8 1}$ was equally active against $\mathrm{TK}^{+}$and $\mathrm{TK}^{-}$deficient VZV mutant virus. However, neither of the arylated analogues $\mathbf{7 9}$ and $\mathbf{8 1}$ were able to decrease herpes simplex virus 1 (HSV-1) and 2 (HSV-2) induced cytopathic effect (Table 5). 
Table 5. Anti-herpesvirus activity of the tested compounds in HEP (human embryonic lung) fibroblasts

\begin{tabular}{|c|c|c|c|c|c|c|c|c|}
\hline \multirow{2}{*}{ Compd } & Cytotoxicity & \multicolumn{7}{|c|}{$\mathrm{EC}_{50}(\mu \mathrm{M})$} \\
\hline & MCC & $\begin{array}{l}\text { HSV-1 } \\
(\mathrm{KOS})\end{array}$ & $\begin{array}{c}\text { HSV-2 } \\
(\mathrm{G})\end{array}$ & $\begin{array}{c}\text { HSV-1 } \\
\text { TK-(KOS }^{-} \\
\text {ACV) }\end{array}$ & $\begin{array}{c}\text { HCMV } \\
\text { (AD- } \\
169)\end{array}$ & $\begin{array}{l}\text { HCMV } \\
\text { (Davis) }\end{array}$ & $\begin{array}{l}\text { VZV } \\
\mathrm{TK}^{+} \\
(\mathrm{Oka})\end{array}$ & $\begin{array}{c}\text { VZV } \\
\mathrm{TK}^{-} \\
(07-1)\end{array}$ \\
\hline $9 \mathbf{a}$ & $>100$ & $>100$ & $>100$ & $>100$ & $>20$ & 20 & 4 & $>20$ \\
\hline 79 & 100 & $>100$ & $>100$ & $>100$ & $10 \pm 2$ & $12 \pm 4$ & 20 & $>20$ \\
\hline 80 & $>100$ & $4.0 \pm 0$ & $47 \pm 37$ & $>100$ & 45 & 20 & 32 & $>100$ \\
\hline 81 & 100 & $>100$ & $>100$ & $>100$ & 10 & 20 & $13 \pm 2$ & $12 \pm 5$ \\
\hline
\end{tabular}

$\mathrm{EC}_{50}$ concentration required to reduce virus-induced cytopathogenicity by $50 \%$

$\mathrm{MCC}$ is the Minimum Cytoxic Concentration required to cause a microscopically detectable alteration of normal cell morphology

In contrast, the 5-(fur-2-yl)uracil nucleoside $\mathbf{8 0}$ emerged among the compounds synthesized as the most potent inhibitor the HSV-1 $\mathrm{TK}^{+}$strain Kos with an $\mathrm{EC}_{50}$ of $4 \mu \mathrm{M}$. However, this analogue (80) was less active against HCMV, HSV-2, and VZV TK ${ }^{+}$Oka strain strain than against HSV-1 while it lacke activity against TK ${ }^{-} \mathrm{HSV}-1$ and VZV (Table 5). The 5-(5-heptylfur-2-yl)-2'-deoxyuridine (81) displayed antiviral activities against parainfluenza virus (Table 6) while all others compounds were inactive.

Table 6. Activity of 5-(5-heptylfur-2-yl)-2'-deoxyuridine against parainfluenza virus

\begin{tabular}{|c|c|c|}
\hline \multirow{2}{*}{ Compound } & Cytotoxicity $(\mu \mathrm{M})$ & $\mathrm{EC}_{50}(\mu \mathrm{M})$ \\
\cline { 2 - 3 } & $\mathrm{MCC}$ & Parainfluenza-3 virus \\
\hline $\mathbf{8 1}$ & $>100$ & $14.8 \pm 8$ \\
\hline
\end{tabular}

$\mathrm{EC}_{50}$ concentration required to reduce virus-induced cytopathogenicity by $50 \%$ $\mathrm{MCC}$ is the Minimum Cytoxic Concentration required to cause a microscopically detectable alteration of normal cell morphology 


\section{EXPERIMENTAL}

\subsection{General synthetic procedures}

${ }^{1} \mathrm{H}$ NMR spectra at $400 \mathrm{MHz}$ and ${ }^{13} \mathrm{C}$ NMR at $100.6 \mathrm{MHz}$ were recorded in $\mathrm{CDCl}_{3}$ unless otherwise noted. All chemical shift values are reported in parts per million (ppm) and referenced to the residual solvent peaks $\left[\mathrm{CDCl}_{3}(7.26 \mathrm{ppm})\right.$ or DMSO- $\left.d_{6}(2.54 \mathrm{ppm})\right]$ for ${ }^{1} \mathrm{H}$ NMR and the $\mathrm{CDCl}_{3}(77.16 \mathrm{ppm})$ or DMSO- $d_{6}(39.52 \mathrm{ppm})$ for ${ }^{13} \mathrm{C}$ NMR spectra, with coupling constant $(J)$ values reported in Hz. HRMS were obtained in TOF (ESI) mode unless otherwise specified. TLC was performed on Merck kieselgel $60-\mathrm{F}_{254}$, and products were detected with $254 \mathrm{~nm}$ light. Merck kieselgel 60 (230-400 mesh) was used for column chromatography. Purity, yields and ratio of the products (crude and/or purified) were established via NMR with calibrated standards. All reagents and solvents were purchased from commercial suppliers and used without further purification. The 5-ethynylpyrimidine nucleosides ${ }^{112,113}$ or 8 -ethynyl-2'-deoxyadenosine ${ }^{117}$ were synthesized following the literature procedure.

\subsection{Synthesis}

\section{5-(1-Chloro/bromo-2-tosylvinyl)uracl/cytosine nucleosides (9a, 8-11, and 19-20).}

Procedure A. 5-Ethynyluracil/cytosine and tosyl hydrazide were dissolved in the acetonitrile and treated with iron(III) halide in the presence of tertiary butyl hydrogen peroxide at $80{ }^{\circ} \mathrm{C}$. The volatiles were evaporated and the residue was column chromatographed to afford (9a, 811, and 19-20).

(E)-3',5'-Di- $\boldsymbol{O}$-acetyl-5-(1-chloro-2-tosylvinyl)-2'-deoxyuridine (9a). Treatment of 3',5'di-O-acetyl-2'-deoxy-5-ethynyluridine $4(336 \mathrm{mg}, 1 \mathrm{mmol})$ with $p$-toluenesulfonyl hydrazide (372 $\mathrm{mg}, 2 \mathrm{mmol}$ ) and $\mathrm{FeCl}_{3} \cdot 6 \mathrm{H}_{2} \mathrm{O}(540 \mathrm{mg}, 2 \mathrm{mmol}$ ) by procedure A (column 
chromatography; hexane/EtOAc, 1:1 $\rightarrow$ 4:6) gave 9a (400 mg, 76\%): ${ }^{1} \mathrm{H}$ NMR $\delta 2.12(\mathrm{~s}, 3 \mathrm{H})$, $2.16(\mathrm{~s}, 3 \mathrm{H}), 2.27-2.37(\mathrm{~m}, 1 \mathrm{H}), 2.42(\mathrm{~s}, 3 \mathrm{H}), 2.58(\mathrm{ddd}, J=1.7,5.5,14.3 \mathrm{~Hz}, 1 \mathrm{H}), 4.30-4.35$ $(\mathrm{m}, 2 \mathrm{H}), 4.46(\mathrm{td}, J=2.3,5.0 \mathrm{~Hz}, 1 \mathrm{H}), 5.27(\mathrm{~d}, J=6.4 \mathrm{~Hz}, 1 \mathrm{H}), 6.35(\mathrm{dd}, J=5.5,8.5 \mathrm{~Hz}$, 1H), 6.89 (s, 1H), 7.32 (d, $J=8.0 \mathrm{~Hz}, 1 \mathrm{H}), 7.69$ (d, $J=8.3 \mathrm{~Hz}, 1 \mathrm{H}), 7.88(\mathrm{~s}, 1 \mathrm{H}), 8.83(\mathrm{~s}, 1 \mathrm{H})$; ${ }^{13} \mathrm{C}$ NMR $\delta 21.02,21.04,21.8,28.8,38.2,64.0,74.4,83.1,85.7,109.2,127.9,130.2,134.7$, 136.7, 139.9, 141.5, 145.6, 149.3, 158.9, 170.5, 170.6; HRMS calcd for $\mathrm{C}_{22} \mathrm{H}_{23}{ }^{35} \mathrm{ClN}_{2} \mathrm{NaO}_{9} \mathrm{~S}$ $[\mathrm{M}+\mathrm{Na}]^{+}$549.0705, found 549.0708.

(E)-2',3',5'-Tri-O-acetyl-5-(1-chloro-2-tosylvinyl)uridine (8). Treatment of 2,3,5-tri- $O$ acetyl-5-ethynyluridine 5 (79 mg, $0.2 \mathrm{mmol}$ ) with $p$-toluenesulfonyl hydrazide $(52.2 \mathrm{mg}, 0.28$ mmol) in the presence of $\mathrm{FeCl}_{3} \cdot 6 \mathrm{H}_{2} \mathrm{O}(108 \mathrm{mg}, 0.4 \mathrm{mmol})$ by procedure A gave 8 ( $80 \mathrm{mg}$, 68\%): ${ }^{1} \mathrm{H}$ NMR $\delta 2.12(\mathrm{~s}, 3 \mathrm{H}), 2.14(\mathrm{~s}, 3 \mathrm{H}), 2.18(\mathrm{~s}, 3 \mathrm{H}), 2.42(\mathrm{~s}, 3 \mathrm{H}), 4.37-4.47$ (m, 3H), 5.36-5.41 (m, 1H), $5.44(\mathrm{t}, J=5.5 \mathrm{~Hz}, 1 \mathrm{H}), 6.10(\mathrm{~d}, J=5.3 \mathrm{~Hz}, 1 \mathrm{H}), 6.94(\mathrm{~s}, 1 \mathrm{H}), 7.32(\mathrm{~d}, J=$ $8.1 \mathrm{~Hz}, 2 \mathrm{H}), 7.71(\mathrm{~d}, J=8.2 \mathrm{~Hz}, 2 \mathrm{H}), 7.82(\mathrm{~s}, 1 \mathrm{H}), 8.63(\mathrm{~s}, 1 \mathrm{H}) ;{ }^{13} \mathrm{C}$ NMR $\delta 20.6,20.7,21.0$, $21.8,63.2,70.4,73.4,80.7,88.0,109.4,128.1,130.2,135.3,136.7,139.6,141.6,145.5$, 149.2, 159.6, 169.6, 169.7, 170.5; HRMS calcd for $\mathrm{C}_{24} \mathrm{H}_{25}{ }^{35} \mathrm{ClN}_{2} \mathrm{NaO}_{11} \mathrm{~S}[\mathrm{M}+\mathrm{Na}]^{+}$607.0760, found 607.0755 .

(E)-5-(1-Chloro-2-tosylvinyl)-2'-deoxyuridine (9). Treatment of 5-ethynyl-2'deoxyuridine 6 (50.5 mg, $0.2 \mathrm{mmol})$ with $p$-toluenesulfonyl hydrazide $(52.2 \mathrm{mg}, 0.28 \mathrm{mmol})$ in the presence of $\mathrm{FeCl}_{3} \cdot 6 \mathrm{H}_{2} \mathrm{O}$ (108 mg, $0.4 \mathrm{mmol}$ ) by procedure A (column chromatography; $\left.\mathrm{CHCl}_{3} / \mathrm{MeOH} ; 9: 1 \rightarrow 85: 15\right)$ gave $9(82 \mathrm{mg}, 90 \%)$ as white solid. ${ }^{1} \mathrm{H}$ NMR $\left(\mathrm{MeOD}-d_{4}\right) \delta 2.25-$ $2.34(\mathrm{~m}, 1 \mathrm{H}), 2.38(\mathrm{ddd}, J=13.4,6.0,4.1 \mathrm{~Hz}, 1 \mathrm{H}), 2.45(\mathrm{~s}, 3 \mathrm{H}), 3.78(\mathrm{dd}, J=12.0,3.5 \mathrm{~Hz}$, $1 \mathrm{H}), 3.84(\mathrm{dd}, J=12.0,2.9 \mathrm{~Hz}, 1 \mathrm{H}), 3.99(\mathrm{dd}, J=6.3,3.0 \mathrm{~Hz}, 1 \mathrm{H}), 4.37-4.53(\mathrm{~m}, 1 \mathrm{H}), 6.31(\mathrm{t}$, $J=6.4 \mathrm{~Hz}, 1 \mathrm{H}), 7.23(\mathrm{~s}, 1 \mathrm{H}), 7.39(\mathrm{~d}, J=7.8 \mathrm{~Hz}, 2 \mathrm{H}), 7.69(\mathrm{~d}, J=7.8 \mathrm{~Hz}, 2 \mathrm{H}), 8.31(\mathrm{~s}, 1 \mathrm{H})$ 
${ }^{13} \mathrm{C}$ NMR (MeOD- $\left.d_{4}\right) \delta 21.6,41.8,62.7,72.0,87.0,89.3,109.7,129.1,131.0,136.0,138.3$, 142.0, 143.9, 146.8, 151.3, 161.6; HRMS calcd for $\mathrm{C}_{18} \mathrm{H}_{19}{ }^{35} \mathrm{ClN}_{2} \mathrm{NaO}_{7} \mathrm{~S}[\mathrm{M}+\mathrm{Na}]^{+} 465.0494$, found 465.0493

(E)-5-(1-Chloro-2-tosylvinyl)uridine (10). Treatment of 5-ethynyluridine 7 (54 mg, 0.2 mmol) with $p$-toluenesulfonyl hydrazide $\left(80 \mathrm{mg}, 0.4 \mathrm{mmol}\right.$ ) in the presence of $\mathrm{FeCl} 3 \cdot 6 \mathrm{H}_{2} \mathrm{O}$ (108 mg, $0.4 \mathrm{mmol}$ ) by procedure A (column chromatography; $\mathrm{CHCl}_{3} / \mathrm{MeOH} ; 95: 5 \rightarrow 90: 10$ ) gave 10 (54 mg, 59\%): UV (MeOH) $\lambda \max 242,276 \mathrm{~nm}(\varepsilon 14$ 100, 10 800), $\lambda \min 230,261 \mathrm{~nm}$ ( $\varepsilon 13200,10200) ;{ }^{1} \mathrm{H}$ NMR (DMSO- $\left.d_{6}\right) \delta 2.41(\mathrm{~s}, 3 \mathrm{H}), 3.58(\mathrm{ddd}, J=12.0,5.0,3.1 \mathrm{~Hz}, 1 \mathrm{H})$, $3.67(\mathrm{ddd}, J=11.9,4.9,3.1 \mathrm{~Hz}, 1 \mathrm{H}), 3.90(\mathrm{q}, J=3.2 \mathrm{~Hz}, 1 \mathrm{H}), 4.01(\mathrm{q}, J=4.9 \mathrm{~Hz}, 1 \mathrm{H}), 4.07$ $(\mathrm{q}, J=5.0 \mathrm{~Hz}, 1 \mathrm{H}), 5.14(\mathrm{~d}, J=5.0 \mathrm{~Hz}, 1 \mathrm{H}), 5.47(\mathrm{~d}, J=5.6 \mathrm{~Hz}, 1 \mathrm{H}), 5.80(\mathrm{~d}, J=4.8 \mathrm{~Hz}$, $1 \mathrm{H}), 7.42(\mathrm{~d}, J=8.1 \mathrm{~Hz}, 2 \mathrm{H}), 7.53(\mathrm{~s}, 1 \mathrm{H}), 7.57-7.79(\mathrm{~m}, 2 \mathrm{H}), 8.25(\mathrm{~s}, 1 \mathrm{H}), 11.67(\mathrm{~s}, 1 \mathrm{H}) ;{ }^{13} \mathrm{C}$ NMR (DMSO- $\left.d_{6}\right) \delta 21.1,60.5,69.5,74.1,79.1,85.0,88.5,108.8,127.6,129.8,134.0,136.9$, 139.6, 141.5, 144.8, 149.8, 159.4; HRMS calcd for: $\mathrm{C}_{18} \mathrm{H}_{19}{ }^{35} \mathrm{ClN}_{2} \mathrm{O}_{8} \mathrm{~S}[\mathrm{M}+\mathrm{H}]+$ for 459.0623, found 459.0620 .

(E)-5-(1-Bromo-2-tosylvinyl)uridine (11). Treatment of $7(54 \mathrm{mg}, 0.2 \mathrm{mmol})$ with $p$ toluenesulfonyl hydrazide ( $80 \mathrm{mg}, 0.4 \mathrm{mmol})$ in the presence of $\mathrm{FeBr}_{3}(36 \mathrm{mg}, 0.2 \mathrm{mmol})$ and column chromatography; $\mathrm{CHCl}_{3} / \mathrm{MeOH}, 95: 5 \rightarrow$ 90:10) gave $\mathbf{1 1}(41.3 \mathrm{mg}, 41 \%): \mathrm{UV}$ (MeOH) $\lambda \max 239,277 \mathrm{~nm}(\varepsilon 13500,10200), \lambda \min 232,264 \mathrm{~nm}(\varepsilon 12800,9600) ;{ }^{1} \mathrm{H}$ NMR $\left(\right.$ DMSO- $\left._{6}\right) \delta 2.4(\mathrm{~s}, 3 \mathrm{H}), 3.54-3.72(\mathrm{~m}, 2 \mathrm{H}), 3.88-3.93(\mathrm{~m}, 1 \mathrm{H}), 3.96-4.1(\mathrm{~m}, 2 \mathrm{H})$, 5.1-5.2 (m, 2H), $5.48(\mathrm{~d}, J=5.6 \mathrm{~Hz}, 1 \mathrm{H}), 5.8(\mathrm{~d}, J=4.6 \mathrm{~Hz}, 1 \mathrm{H}), 7.43(\mathrm{~d}, J=7.9 \mathrm{~Hz}, 2 \mathrm{H}), 7.65(\mathrm{~S}, 1 \mathrm{H})$, $7.68(\mathrm{~d}, J=7.5 \mathrm{~Hz}, 2 \mathrm{H}), 8.22(\mathrm{~s}, 1 \mathrm{H}), 11.68(\mathrm{~s}, 1 \mathrm{H}) ;{ }^{13} \mathrm{C}$ NMR (DMSO- $\left.d_{6}\right) \delta 21.1,60.5,69.6$, 74.2, 85.0, 88.5, 110.4, 127.7, 129.3, 129.8, 136.7, 136.9, 140.7, 144.8, 149.7, 159.3; HRMS calcd for $\mathrm{C}_{18} \mathrm{H}_{19}{ }^{81} \mathrm{BrN}_{2} \mathrm{NaO}_{8} \mathrm{~S}[\mathrm{M}+\mathrm{Na}]+526.9917$, found 526.9916. 
(E)-3',5'-Di-O-acetyl-5-(1-chloro-2-tosylvinyl)-2'-deoxycytidine (19). Treatment of 3',5'-di- $\boldsymbol{O}$-acetyl-5-ethynylcytidine $17(156 \mathrm{mg}, \quad 0.465 \mathrm{mmol})$ with $p$-toluenesulfonyl hydrazide (261 mg, $1.39 \mathrm{mmol})$ in the presence of $\mathrm{FeCl}_{3} \cdot 6 \mathrm{H}_{2} \mathrm{O}(252 \mathrm{mg}, 0.93 \mathrm{mmol})$ by procedure A (column chromatography; $\mathrm{CHCl}_{3} / \mathrm{MeOH} ; 100: 0 \rightarrow$ 90:5) gave $19(168 \mathrm{mg}$, 68\%): ${ }^{1} \mathrm{H}$ NMR (DMSO-d 6$) \delta 1.97$ (s, 3H), 2.08 (s, 3H), 2.28-2.35 (m, 2H), 2.40 (s, 3H), 4.15-4.26 (m, 3H), $5.18(\mathrm{br}, 1 \mathrm{H}), 6.12(\mathrm{br}, 1 \mathrm{H}), 7.40(\mathrm{~d}, J=6.8 \mathrm{~Hz}, 2 \mathrm{H}), 7.65(\mathrm{~d}, J=7.1 \mathrm{~Hz}$, 2H), $7.70(\mathrm{~s}, 1 \mathrm{H}), 7.80(\mathrm{~s}, 1 \mathrm{H}) ;{ }^{13} \mathrm{C}$ NMR (DMSO- $\left.d_{6}\right) \delta 20.3,20.7,21.0,38.5,63.0,74.0$, 75.0, 81.5, 86.0, 101.0, 127.5, 130.0, 136.0, 136.3, 141.2, 145.0, 147.0, 159.5, 169.5, 170.0 . HRMS calcd for $\mathrm{C}_{22} \mathrm{H}_{25}{ }^{35} \mathrm{ClN}_{3} \mathrm{O}_{8} \mathrm{~S}[\mathrm{M}+\mathrm{H}]^{+}$for 526.1051 , found 526.1046

(E)-2',3',5'-Tri-O-acetyl-5-(1-chloro-2-tosylvinyl)cytidine (20). Treatment of 3',5'-di- $O$ acetyl-5-ethynylcytidine 18 (66 mg, $0.167 \mathrm{mmol})$ with $p$-toluenesulfonyl hydrazide (90 mg, $0.5 \mathrm{mmol}$ ) in the presence of $\mathrm{FeCl}_{3} \cdot 6 \mathrm{H}_{2} \mathrm{O}(91 \mathrm{mg}, 0.33 \mathrm{mmol}$ ) by procedure A (column chromatography; $\mathrm{CHCl}_{3} / \mathrm{MeOH} ; 100: 0 \rightarrow$ 90:5) gave $20(48 \mathrm{mg}, 60 \%):{ }^{1} \mathrm{H} \mathrm{NMR}\left(\mathrm{CDCl}_{3}\right) \delta$ $2.10(\mathrm{~s}, 3 \mathrm{H}), 2.14(\mathrm{~s}, 3 \mathrm{H}), 2.16(\mathrm{~s}, 3 \mathrm{H}), 2.40(\mathrm{~s}, 3 \mathrm{H}), 4.38-4.48(\mathrm{~m}, 3 \mathrm{H}), 5.38(\mathrm{dd}, J=10.1,5.5$ $\mathrm{Hz}, 1 \mathrm{H}), 5.49(\mathrm{t}, J=5.2 \mathrm{~Hz}, 1 \mathrm{H}), 6.06(\mathrm{~d}, J=5.3 \mathrm{~Hz}, 1 \mathrm{H}), 7.10(\mathrm{~s}, 1 \mathrm{H}), 7.32(\mathrm{~d}, J=8.2 \mathrm{~Hz}$ $2 \mathrm{H}), 7.68(\mathrm{~d}, J=8.3 \mathrm{~Hz}, 1 \mathrm{H}), 7.88(\mathrm{~s}, 1 \mathrm{H}) ;{ }^{13} \mathrm{C} \mathrm{NMR}\left(\mathrm{CDCl}_{3}\right) \delta$ 20.4, 20.5, 20.8, 21.8, 63.0, 70.0, 74.0, 80.0, 89.5, 101.0, 128.0, 131.0, 136.0, 137.5, 139.5, 144.0, 146.0, 153.0, 160.5, $169.5,169.7,170.5$

(E)-5-(1-Iodo-2-tosylvinyl)uridine (12). 5-Ethynyluridine $7(26.8 \mathrm{mg}, 0.1 \mathrm{mmol})$ was dissolved in $5 \mathrm{~mL}$ THF.Then sodium $p$-toluenesulfinate $(35.6 \mathrm{mg}, 0.2 \mathrm{mmol})$ and NIS (23 mg, $0.1 \mathrm{mmol}$ ) were sequentially added into the solution and the resulting mixtures were stirred at $64{ }^{\circ} \mathrm{C}$ for $4 \mathrm{~h}$. Volatiles were evaporated and column chromatography; $\mathrm{CHCl}_{3} / \mathrm{MeOH} ; 95: 5 \rightarrow$ 90:10) gave 12 (21.5 mg, 42\%): UV (MeOH) $\lambda \max 235,262,291$ (sh) nm ( $\varepsilon 14150,12650)$, 
$\lambda \min 220,252 \mathrm{~nm}(\varepsilon 13$ 100, 12 400); 1H NMR (DMSO $d 6) \delta 2.4(\mathrm{~s}, 3 \mathrm{H}), 3.54-3.70(\mathrm{~m}, 2 \mathrm{H})$, 3.87-3.92 (m, 1H), 3.97-4.09 (m, 2H), $5.8(\mathrm{~d}, J=4.9 \mathrm{~Hz}, 1 \mathrm{H}), 7.4(\mathrm{~d}, J=8.1 \mathrm{~Hz}, 2 \mathrm{H}), 7.65(\mathrm{~d}$, $J=8.3 \mathrm{~Hz}, 2 \mathrm{H}), 7.72(\mathrm{~s}, 1 \mathrm{H}), 8.07(\mathrm{~s}, 1 \mathrm{H}), 11.6(\mathrm{~s}, 1 \mathrm{H}) ; 13 \mathrm{C}$ NMR (DMSO-d6) $\delta$ 21.1, 60.7, 69.7, 74.1, 85.1, 88.4, 99.5, 111.4, 127.6, 129.8, 136.7, 138.3, 142.6, 144.6, 149.8, 159.2; HRMS calculated for $\mathrm{C}_{18} \mathrm{H}_{19} \mathrm{IN}_{2} \mathrm{NaO}_{8} \mathrm{~S}[\mathrm{M}+\mathrm{Na}]+572.9799$, found 572.9798 .

$\beta$-Substituted analogues after displacement of halogen via addition-elimination reaction (26-29, 32-33). Procedure B. Chlorovinyl sulfone analogues were dissolved in methanol. Then methanolic ammonia, or thiol nucleophilic sources with triethyl amine was added into the solution and the resulting mixtures were stirred at ambient temperature. The volatiles were evaporated and the residue was column chromatographed to afford (26-29, 3233).

(E)-5-(1-(propylthio)-2-tosylvinyl)-2'-deoxyuridine (26). Treatment of 9 (30 mg, 0.07 mmol) with $n$-Propanethiol $(7.4 \mu \mathrm{L}, 6.2 \mathrm{mg}, 0.08 \mathrm{mmol})$ in the presence of $\mathrm{Et}_{3} \mathrm{~N}(11.3 \mu \mathrm{L}, 8.2$ $\mathrm{mg}, 0.08 \mathrm{mmol}$ ) for $2 \mathrm{~h}$ following the procedure $\mathrm{B}$ (column chromatography; $\mathrm{CHCl}_{3}: \mathrm{MeOH}=$ 95:5 $\rightarrow$ 90:10) gave $\boldsymbol{E}-26(22 \mathrm{mg}, 68 \%) . \mathrm{UV}(\mathrm{MeOH}) \lambda_{\max }=275 \mathrm{~nm} ;{ }^{1} \mathrm{H} \mathrm{NMR}(400 \mathrm{MHz}$, DMSO- $\left.d_{6}\right) \delta 0.93(\mathrm{t}, J=7.3 \mathrm{~Hz}, 3 \mathrm{H}) 1.47-1.64(\mathrm{~m}, 2 \mathrm{H}), 2.00-2.11(\mathrm{~m}, 1 \mathrm{H}), 2.14-2.19(\mathrm{~m}$, 1H), 2.39 (s, 3H), 2.80 (t, $J=7.2 \mathrm{~Hz}, 2 \mathrm{H}), 3.55(\mathrm{dd}, J=3.5,7.9 \mathrm{~Hz}, 2 \mathrm{H}), 3.82(\mathrm{dd}, J=3.04$, $6.04 \mathrm{~Hz}, 1 \mathrm{H}), 4.22-4.26(\mathrm{~m}, 1 \mathrm{H}), 5.00(\mathrm{t}, J=4.9 \mathrm{~Hz}, 1 \mathrm{H}), 5.27(\mathrm{~d}, J=4.2 \mathrm{~Hz}, 1 \mathrm{H}), 6.17(\mathrm{t}, J=$ $6.7 \mathrm{~Hz}, 1 \mathrm{H}), 6.46(\mathrm{~s}, 1 \mathrm{H}), 7.38(\mathrm{~d}, J=8.1 \mathrm{~Hz}, 2 \mathrm{H}), 7.66(\mathrm{~d}, J=8.2 \mathrm{~Hz}, 2 \mathrm{H}), 7.89(\mathrm{~s}, 1 \mathrm{H})$, $11.51(\mathrm{~s}, 1 \mathrm{H}) ;{ }^{13} \mathrm{C}$ NMR (100 MHz, DMSO- $\left.d_{6}\right) \delta 13.2,20.6,21.1,33.6,61.2,70.4,84.6,87.7$, 122.3, 127.0, 129.5, 138.8, 143.7, 149.8, 160.1; HRMS calcd for $\mathrm{C}_{21} \mathrm{H}_{26} \mathrm{~N}_{2} \mathrm{NaO}_{7} \mathrm{~S}_{2}[\mathrm{M}+\mathrm{Na}]^{+}$ 505.1074, found 505.1077. 
(E)-5-(1-Propylthio-2-tosylvinyl)uridine (27). Treatment of $\mathbf{1 0}(48 \mathrm{mg}, 0.1 \mathrm{mmol})$ with n-propanethiol (11 $\mu \mathrm{L}, 9 \mathrm{mg}, 0.12 \mathrm{mmol})$ in the presence of $\mathrm{Et}_{3} \mathrm{~N}(17 \mu \mathrm{L}, 12 \mathrm{mg}, 0.12 \mathrm{mmol})$ for $2 \mathrm{~h}$ following the procedure $\mathrm{B}$ and column chromatography $\left(\mathrm{CHCl}_{3} / \mathrm{MeOH}, 95: 5 \rightarrow 9: 1\right)$ gave 27 (38 mg, 75\%) as white solid: 1H NMR (DMSO-d6) $\delta 0.95$ (t, $J=7.8 \mathrm{~Hz}, 3 \mathrm{H}$ ), 1.55 (m, 2H), $2.40(\mathrm{~s}, 3 \mathrm{H}), 2.80(\mathrm{t}, J=7.8 \mathrm{~Hz}, 2 \mathrm{H}), 3.52-3.68(\mathrm{~m}, 2 \mathrm{H}), 3.90(\mathrm{~m}, 1 \mathrm{H}), 3.95-4.07(\mathrm{~m}$, 2H), 5.04 (brs, 1H) 5.15 (brs, 1H), $5.45(\mathrm{~d}, J=5.8 \mathrm{~Hz}, 1 \mathrm{H}), 5.80(\mathrm{~d}, J=5.1 \mathrm{~Hz}, 1 \mathrm{H}), 7.38(\mathrm{~d}$, $J=8.1 \mathrm{~Hz}, 2 \mathrm{H}), 7.68(\mathrm{~d}, J=8.2 \mathrm{~Hz}, 2 \mathrm{H}), 7.96(\mathrm{~s}, 1 \mathrm{H}), 8.32(\mathrm{~s}, 1 \mathrm{H}), 11.45(\mathrm{~s}, 1 \mathrm{H}) ; 13 \mathrm{C}$ NMR (DMSO-d6) $\delta$ 13.2, 20.6, 21.1, 33.6, 60.7, 69.8, 74.0, 85.0, 88.2, 109.2, 122.1, 127.1, 128.4, $129.5,138.2,138.8,143.6,150.1,160.1$; HRMS calculated for $\mathrm{C}_{21} \mathrm{H}_{26} \mathrm{~N}_{2} \mathrm{NaO}_{8} \mathrm{~S}_{2}[\mathrm{M}+\mathrm{Na}]+$ 521.1023, found 521.1019.

$S$-[(E)-1-(2'-Deoxyuridin-5-yl)-2-tosylvinyl]-L-cysteine ethyl ester (28). Treatment of 9 (30 mg, $0.07 \mathrm{mmol}$ ) with L-cysteine ethyl ester hydrogen chloride (36 mg, $0.02 \mathrm{mmol}, 3 \mathrm{eq}$.) in the presence of $\mathrm{Et}_{3} \mathrm{~N}(11.3 \mu \mathrm{L}, 8.2 \mathrm{mg}, 0.08 \mathrm{mmol}, 1.2 \mathrm{eq}$. $)$ for $2 \mathrm{~h}$ following the procedure B (column chromatography; $\left.\mathrm{CHCl}_{3}: \mathrm{MeOH}=95: 5 \rightarrow 90: 10\right)$ gave $28(27 \mathrm{mg}, 70 \%, \mathrm{E} / \mathrm{Z}$, 80:20) as a mixture of region isomers and further purification gave $\mathbf{2 8}$ (19 $\mathrm{mg}, 50 \%)$ as single isomer. ${ }^{1} \mathrm{H}$ NMR (400 MHz, MeOD- $\left.d_{4}\right) \delta 1.32(\mathrm{t}, J=7.2 \mathrm{~Hz}, 3 \mathrm{H}), 2.14(\mathrm{ddd}, J=5.9,7.3,13.5$ $\mathrm{Hz}, 1 \mathrm{H}), 2.30$ (ddd, $J=3.1,6.2,13.6 \mathrm{~Hz}, 1 \mathrm{H}), 2.43(\mathrm{~s}, 3 \mathrm{H}), 3.02(\mathrm{dd}, J=7.8,10.5 \mathrm{~Hz}, 1 \mathrm{H})$, $3.12(\mathrm{dd}, J=5.6,10.5 \mathrm{~Hz}, 1 \mathrm{H}), 3.76(\mathrm{dd}, J=3.7,11.9 \mathrm{~Hz}, 1 \mathrm{H}), 3.83(\mathrm{dd}, J=3.6,11.9 \mathrm{~Hz}$, 1H), $3.99(\mathrm{~d}, J=14.9 \mathrm{~Hz}, 1 \mathrm{H}), 4.03(\mathrm{q}, J=3.4 \mathrm{~Hz}, 1 \mathrm{H}), 4.08(\mathrm{dd}, J=5.6,7.8 \mathrm{~Hz}, 1 \mathrm{H}), 4.27$ $(\mathrm{q}, J=7.1 \mathrm{~Hz}, 2 \mathrm{H}), 4.38(\mathrm{dt}, J=3.0,6.0 \mathrm{~Hz}, 1 \mathrm{H}), 4.75(\mathrm{~d}, J=14.9 \mathrm{~Hz}, 1 \mathrm{H}), 6.24(\mathrm{t}, J=6.7$ $\mathrm{Hz}, 1 \mathrm{H}), 7.33(\mathrm{~d}, J=8.1 \mathrm{~Hz}, 2 \mathrm{H}), 7.57(\mathrm{~d}, J=8.3 \mathrm{~Hz}, 2 \mathrm{H}), 7.99(\mathrm{~s}, 1 \mathrm{H}) ;{ }^{13} \mathrm{C} \mathrm{NMR}(100 \mathrm{MHz}$ $\left.\mathrm{MeOD}-d_{4}\right) \delta 14.5,21.7,37.1,41.7,62.8,63.3,63.6,67.1,72.7,74.5,87.0,89.4,116.4,130.0$ 130.9, 137.1, 138.1, 146.5, 151.6, 163.6, 172.8; ${ }^{13} \mathrm{C}$ NMR (101 MHz, MeOD) $\delta 172.77$, 
163.62, 151.64, 146.47, 138.11, 137.10, 130.89, 129.98, 116.37, 89.40, 87.01, 74.51, 72.73, 67.13, 63.64, 63.30, 62.79, 41.73, 37.08, 21.66, 14.47; HRMS calcd for $\mathrm{C}_{23} \mathrm{H}_{29} \mathrm{~N}_{3} \mathrm{NaO}_{9} \mathrm{~S}_{2}$ $[\mathrm{M}+\mathrm{Na}]^{+}$for 578.1237 , found 578.1239

$S$-[(E)-1-(Uridin-5-yl)-2-tosylvinyl]-L-cysteine ethyl ester (29). Treatment of 10 (19 $\mathrm{mg}, 0.04 \mathrm{mmol})$ with L-cysteine ethyl ester hydrogen chloride $(22.8 \mathrm{mg}, 0.12 \mathrm{mmol})$ in the presence of $\mathrm{Et}_{3} \mathrm{~N}(45.7 \mu \mathrm{L}, 33.2 \mathrm{mg}, 0.32 \mathrm{mmol})$ for $2 \mathrm{~h}$ following the procedure $\mathrm{B}$ and column chromatography; $\mathrm{CHCl} / \mathrm{MeOH}, 95: 5 \rightarrow 9: 1)$ gave $29(E / Z, 85: 15 ; 13 \mathrm{mg}, 56 \%)$ as white solid. The $E$-isomer had: 1H NMR (DMSO- $d 6$ ) $\delta 1.20(\mathrm{t}, J=7.2 \mathrm{~Hz}, 3 \mathrm{H}), 2.40(\mathrm{~s}, 3 \mathrm{H}$ ), $2.95(\mathrm{dd}, J=10.5,7.8 \mathrm{~Hz}, 1 \mathrm{H}), 3.09(\mathrm{dd}, J=10.5,5.6 \mathrm{~Hz}, 1 \mathrm{H}), 3.53-3.58(\mathrm{~m}, 2 \mathrm{H}), 3.61-3.63$ (m, $1 \mathrm{H}), 3.87-3.90(\mathrm{~m}, 1 \mathrm{H}), 3.95-4.00(\mathrm{~m}, 2 \mathrm{H}), 4.04-4.12(\mathrm{~m}, 4 \mathrm{H}), 5.00-5.20(\mathrm{~m}, 2 \mathrm{H}), 5.45$ $(\mathrm{d}, J=5.7 \mathrm{~Hz}, 1 \mathrm{H}), 5.80(\mathrm{~d}, J=5.1 \mathrm{~Hz}, 1 \mathrm{H}), 6.58(\mathrm{~s}, 1 \mathrm{H}), 7.48(\mathrm{~d}, J=8.1 \mathrm{~Hz}, 2 \mathrm{H}), 7.68(\mathrm{~d}, J$ $=8.3 \mathrm{~Hz}, 2 \mathrm{H}), 7.96(\mathrm{~s}, 1 \mathrm{H}), 11.50(\mathrm{~s}, 1 \mathrm{H}) ; 13 \mathrm{C}$ NMR (DMSO-d6) $\delta$ 14.0, 21.0, 37.0, 53.5, $61.5,61.6,69.5,74.0,85.0,88.5,96.0,116.0,122.5,127.5,128.5,129.5,138.5,143.5,150.5$ 160.0, 173.0; HRMS calculated for $\mathrm{C}_{23} \mathrm{H}_{29} \mathrm{~N}_{3} \mathrm{NaO}_{10} \mathrm{~S}_{2}[\mathrm{M}+\mathrm{Na}]+594.1187$, found 594.1173.

$S$-[(E)-1-(2'-Deoxyuridin-5-yl)-2-tosylvinyl]-L-glutathione $\quad$ (30). The $\quad$ 5-( $(\beta-$ chloro)vinyl sulfone analogue $9(25 \mathrm{mg}, 0.056 \mathrm{mmol})$ was dissolved in $1 \mathrm{~mL}$ methanol-water (80:20) cosolvent system. Then, L-glutathione $(25.8 \mathrm{mg}, 0.084 \mathrm{mmol})$ and $\mathrm{Et}_{3} \mathrm{~N}(59.0 \mu \mathrm{L}$, $42.5 \mathrm{mg}, 0.42 \mathrm{mmol}$ ) were sequentially added and the resulting mixtures were stirred at ambient temperature for $4 \mathrm{~h}$. The volatile were evaporated and reverse phase HPLC separation gave $30(22 \mathrm{mg}, 55 \%)$ as white solid. 1H NMR $\left(\mathrm{D}_{2} \mathrm{O}\right) \delta 2.15(\mathrm{q}, J=7.2 \mathrm{~Hz}, 2 \mathrm{H}), 2.27-2.39$ (m, 2H) $2.45(\mathrm{~s}, 3 \mathrm{H}), 2.50(\mathrm{t}, J=7.5 \mathrm{~Hz}, 2 \mathrm{H}), 3.24-3.45(\mathrm{~m}, 2 \mathrm{H}), 3.70-3.80(\mathrm{~m}, 3 \mathrm{H}), 3.85-$ $4.02(\mathrm{~m}, 2 \mathrm{H}), 4.08(\mathrm{br}, 1 \mathrm{H}), 4.50(\mathrm{br}, 1 \mathrm{H}), 4.60-4.70(\mathrm{~m}, 2 \mathrm{H}), 6.25(\mathrm{t}, J=6.7 \mathrm{~Hz}, 1 \mathrm{H}), 6.85(\mathrm{~s}$, $1 \mathrm{H}), 7.42(\mathrm{~d}, J=8.1 \mathrm{~Hz}, 2 \mathrm{H}), 7.61(\mathrm{~d}, J=8.0 \mathrm{~Hz}, 2 \mathrm{H}), 7.70(\mathrm{~s}, 1 \mathrm{H}) ;{ }^{13} \mathrm{C} \mathrm{NMR}\left(\mathrm{D}_{2} \mathrm{O}\right) \delta 21.0$, 
$26.4,31.0,33.0,39.5,43.8,52.0,54.0,61.0,70.0,85.5,94.0,108.0,126.0,130.0,135.0$, 136.0, 142.0, 145.8, 151.0, 159.8, 170.7, 174.0, 175.0, 176.2; HRMS calculated for $\mathrm{C}_{28} \mathrm{H}_{35} \mathrm{~N}_{5} \mathrm{O}_{16} \mathrm{PS}_{2}[\mathrm{M}-\mathrm{H}]^{-} 792.12633$, found 792.121640

(Z)-5-(1-Amino-2-tosylvinyl)uridine (32). Treatment (2 h) of $\mathbf{1 0}(25 \mathrm{mg}, 0.054 \mathrm{mmol})$ with $\mathrm{NH}_{3} / \mathrm{MeOH}(3 \mathrm{~mL})$ by the procedure $\mathrm{B}$ and column chromatography; $\mathrm{CHCl}_{3} / \mathrm{MeOH}$, 9:1) gave 32 (20 mg, 84\%): 1H NMR (DMSO- $d 6) \delta 2.37$ (s, 3H), 3.59 (ddd, $J=2.8,5.3,12.3$ $\mathrm{Hz}, 1 \mathrm{H}), 3.68(\mathrm{ddd}, J=3.0,5.0,12.3 \mathrm{~Hz}, 1 \mathrm{H}), 3.86-3.8(\mathrm{~m}, 1 \mathrm{H}), 4.00(\mathrm{q}, J=5.19 \mathrm{~Hz}, 1 \mathrm{H})$, 4.10-4.14 (m, 2H), $5.11(\mathrm{~d}, J=5.6 \mathrm{~Hz}, 1 \mathrm{H}), 5.21(\mathrm{~s}, 1 \mathrm{H}), 5.29(\mathrm{t}, J=5.1 \mathrm{~Hz}, 1 \mathrm{H}), 5.44(\mathrm{~d}, J=$ $5.4 \mathrm{~Hz}, 1 \mathrm{H}), 5.72(\mathrm{~d}, J=4.2 \mathrm{~Hz}, 1 \mathrm{H}), 6.99(\mathrm{~s}, 2 \mathrm{H}), 7.35(\mathrm{~d}, J=8.1 \mathrm{~Hz}, 2 \mathrm{H}), 7.76(\mathrm{~d}, J=8.2$ $\mathrm{Hz}, 2 \mathrm{H}), 8.33(\mathrm{~s}, 1 \mathrm{H}), 11.66$ (s, 1H); 13C NMR (DMSO-d $\left.)_{6}\right) \delta$ 20.9, 60.2, 69.1, 73.9, 84.8, 88.2, 89.1, 107.2, 125.5, 129.4, 141.5, 142.2, 142.3, 149.4, 150.7, 161.6; HRMS calculated for $\mathrm{C}_{18} \mathrm{H}_{22} \mathrm{~N}_{3} \mathrm{O}_{8} \mathrm{~S}[\mathrm{M}+\mathrm{H}]+440.1122$, found 440.1100.

5-[1-(n-Aminobutyl)-2-tosylvinyl]uridine (33). Treatment of $\beta$-chlorovinyl analogue 10 (25 mg, $0.054 \mathrm{mmol}$ ) with n-butyl amine $27 \mu \mathrm{L}, 20 \mathrm{mg}, 0.27 \mathrm{mmol}$ ) for $5 \mathrm{~h}$ following the procedure B and column chromatography; $\mathrm{CHCl}_{3} / \mathrm{MeOH}, 95: 5 \rightarrow$ 90:10) gave $33(19 \mathrm{mg}$, $71 \%)$ as $E / Z$ mixtures (85:15). The major isomer had: $1 \mathrm{H} \mathrm{NMR}\left(\mathrm{MeOH}-d_{4}\right) \delta 0.85(\mathrm{t}, J=7.5$ $\mathrm{Hz}, 3 \mathrm{H}$ ), 1.40 (sex, $J=7.2 \mathrm{~Hz}, 2 \mathrm{H}$ ), 1.58 (quin, $J=7.5 \mathrm{~Hz}, 2 \mathrm{H}$ ), 2.40 (s, 3H), 3.00 (t, $J=7.0$ $\mathrm{Hz}, 2 \mathrm{H}), 3.75(\mathrm{dd}, J=10.3,6.0 \mathrm{~Hz}, 1 \mathrm{H}), 3.82(\mathrm{dd}, J=10.2,5.8 \mathrm{~Hz}, 1 \mathrm{H}), 4.0-4.05(\mathrm{~m}, 1 \mathrm{H})$, $4.20(\mathrm{ddd}, J=9.4,6.4,2.3 \mathrm{~Hz}, 1 \mathrm{H}), 4.25(\mathrm{dd}, J=9.7,4.6 \mathrm{~Hz}, 1 \mathrm{H}), 5.00(\mathrm{~s}, 1 \mathrm{H}), 5.9(\mathrm{~d}, J=$ $4.5 \mathrm{~Hz}, 1 \mathrm{H}), 7.25(\mathrm{~d}, J=8.4 \mathrm{~Hz}, 2 \mathrm{H}), 7.60(\mathrm{~d}, J=8.3 \mathrm{~Hz}, 2 \mathrm{H}), 7.95(\mathrm{~s}, 1 \mathrm{H})$.

(E)-5-(2-Tosylvinyl)uridine (36). Step a. p-Toluenesulfonic acid (62 mg, $0.4 \mathrm{mmol})$ was added to a solution of 2',3',5'-tri- $O$-acetyl-5-ethynyluridine $5(68 \mathrm{mg}, 0.17 \mathrm{mmol})$ in dry THF 
(3 mL) containing $\mathrm{Cu}(\mathrm{OAc}) 2 \cdot 2 \mathrm{H} 2 \mathrm{O}(3 \mathrm{mg}, 0.015 \mathrm{mmol})$ under nitrogen at ambient temperature. The resulting solution was stirred at $60{ }^{\circ} \mathrm{C}$ (oil bath) for $7 \mathrm{~h}$. After cooling to ambient temperature, the volatiles were evaporated under the reduced pressure and the residue was column chromatographed (hexane/EtOAc, $1: 1 \rightarrow 4: 6)$ to give $(E)-2^{\prime}, 3^{\prime}, 5^{\prime}$-tri- $O$-acetyl-5-(2tosylvinyl)uridine (31.5 mg, 35\%): ${ }^{1} \mathrm{H}$ NMR $\delta 2.10(\mathrm{~s}, 3 \mathrm{H}), 2.12(\mathrm{~s}, 2 \mathrm{H}), 2.21(\mathrm{~s}, 3 \mathrm{H}), 2.42(\mathrm{~s}$, $3 \mathrm{H}), 4.30-4.51(\mathrm{~m}, 3 \mathrm{H}), 5.31(\mathrm{t}, J=5.3 \mathrm{~Hz}, 1 \mathrm{H}), 5.36(\mathrm{t}, J=5.2 \mathrm{~Hz}, 1 \mathrm{H}), 6.00(\mathrm{~d}, J=4.8$ $\mathrm{Hz}, 1 \mathrm{H}), 7.19(\mathrm{~d}, J=15.0 \mathrm{~Hz}, 1 \mathrm{H}), 7.32(\mathrm{~d}, J=8.0 \mathrm{~Hz}, 2 \mathrm{H}), 7.62(\mathrm{~d}, J=15.0 \mathrm{~Hz}, 1 \mathrm{H}), 7.76$ (d, $J=8.2 \mathrm{~Hz}, 2 \mathrm{H}), 7.79(\mathrm{~s}, 1 \mathrm{H}), 8.70(\mathrm{~s}, 1 \mathrm{H})$. Step $b$. Methanolic ammonia $(1.5 \mathrm{~mL})$ was added to the solution of the material $(25.5 \mathrm{mg}, 0.045 \mathrm{mmol})$ in $\mathrm{MeOH}(1.5 \mathrm{~mL})$ at $0{ }^{\circ} \mathrm{C}$ and the resulting solution was stirred for overnight. Volatiles were evaporated and the residue was column chromatographed (CHCl3/MeOH, 9:1) to give 36 (12 mg, 63\%): 1H NMR (MeODd4) $\delta 2.42(\mathrm{~s}, 3 \mathrm{H}), 3.77(\mathrm{dd}, J=12.4,2.6 \mathrm{~Hz}, 1 \mathrm{H}), 3.93(\mathrm{dd}, J=12.4,2.6 \mathrm{~Hz}, 1 \mathrm{H}), 4.02(\mathrm{dt}, J$ $=5.2,2.6 \mathrm{~Hz}, 1 \mathrm{H}), 4.12-4.21(\mathrm{~m}, 2 \mathrm{H}), 5.87(\mathrm{~d}, J=3.1 \mathrm{~Hz}, 1 \mathrm{H}), 7.30(\mathrm{~d}, J=15.0 \mathrm{~Hz}, 1 \mathrm{H})$, $7.39(\mathrm{~d}, J=8.0 \mathrm{~Hz}, 2 \mathrm{H}), 7.48(\mathrm{~d}, J=15.0 \mathrm{~Hz}, 1 \mathrm{H}), 7.74(\mathrm{~d}, J=8.4 \mathrm{~Hz}, 2 \mathrm{H}), 8.61(\mathrm{~s}, 1 \mathrm{H}) ; 13 \mathrm{C}$ NMR (MeOD- $d 4) \delta 21.5,61.5,70.4,76.2,86.2,91.3,108.7,128.2,128.5,131.1,136.2$ 139.6, 145.8, 146.6, 151.1, 163.3. HRMS calculated for $\mathrm{C}_{18} \mathrm{H}_{20} \mathrm{~N}_{2} \mathrm{NaO}_{8} \mathrm{~S}[\mathrm{M}+\mathrm{Na}]+447.0833$, found 447.0802 .

\section{Synthesis of protected 5-( $\beta$-keto sulfone) of uracil nucleoside (49, 50a and 50b).}

General Procedure C. Protected 5-ethylnyluracil nucleosides were taken in a round bottom flask and dissolved in 1,2 dichloroethane. Then freshly prepared $p$-toluenesulfinic acid and pyridine were sequentially added into the solution. A balloon filled with oxygen was connected with the flask and the resulting mixtures were placed in an oil bath and stirred at 45 
${ }^{\circ} \mathrm{C}$ for $4 \mathrm{~h}$. The reaction mixtures were washed with dil. $\mathrm{HCl}$ followed by $\mathrm{NaHCO}_{3}$ solution. The organic layer was column chromatographed to afford $(\mathbf{3 5}, \mathbf{5 0 a}$, and $\mathbf{5 0 b})$.

1-N-benzyl-5-(2-tosylacetyl)uracil (49). Treatment of 1-N-benzyl-5-ethynyluracil 48 (45.2 $\mathrm{mg}, 0.2 \mathrm{mmol})$ with $p$-toluenesulfinic acid $(156 \mathrm{mg}, 1.0 \mathrm{mmol})$ and pyridine ( $66 \mu \mathrm{L}$, $64.9 \mathrm{mg}, 0.82 \mathrm{mmol}$ ) in the presence of oxygen (balloon) by procedure $\mathrm{C}$ and column chromatography (Hexane : EtOAc = 1:1) gave $49(35 \mathrm{mg}, 44 \%)$ as white solid. $1 \mathrm{H}$ NMR $\delta$ $2.42(\mathrm{~s}, 3 \mathrm{H}), 4.98(\mathrm{~s}, 4 \mathrm{H}), 7.29(\mathrm{~d}, J=8.0 \mathrm{~Hz}, 2 \mathrm{H}), 7.34-7.31(\mathrm{~m}, 2 \mathrm{H}), 7.45-7.37(\mathrm{~m}, 3 \mathrm{H}), 7.79$ $(\mathrm{d}, J=8.3 \mathrm{~Hz}, 2 \mathrm{H}), 8.23(\mathrm{~s}, 1 \mathrm{H}), 8.46(\mathrm{~s}, 1 \mathrm{H}) ; 13 \mathrm{C}$ NMR $\delta 21.8,52.9,65.4,112.0,128.58$, 128.61, 129.4, 129.6, 129.9, 133.9, 137.0, 145.3, 149.6, 151.7, 160.5, 183.8; HRMS calcd for $\mathrm{C}_{20} \mathrm{H}_{19} \mathrm{~N}_{2} \mathrm{O}_{5} \mathrm{~S}[\mathrm{M}+\mathrm{H}]+399.1009$, found 399.1017.

3',5'-Di-O-acetyl-5-(2-tosylacetyl)-2'-deoxyuridine (50a) Treatment of protected 5ethynyl-2'-deoxyuridne $4(25 \mathrm{mg}, 0.074 \mathrm{mmol})$ with $p$-toluenesufinic acid $(58 \mathrm{mg}$, $0.372 \mathrm{mmol}$ ) and pyridine ( $14.5 \mu \mathrm{L}, 14.2 \mathrm{mg}, 0.372 \mathrm{mmol}$ ) in the presence of oxygen (balloon) by procedure $\mathrm{C}$ and column chromatography (Hexane/EA ; 60:40 $\rightarrow$ 40:60) gave 50a $(6 \mathrm{mg}$, $16 \%)$ as white solid: ${ }^{1} \mathrm{H}$ NMR $\left(\mathrm{CDCl}_{3}\right) \delta 2.13(\mathrm{~s}, 3 \mathrm{H}), 2.16(\mathrm{~s}, 3 \mathrm{H}), 2.45(\mathrm{~s}, 3 \mathrm{H}), 2.58-2.66(\mathrm{~m}$, 1H), 2.74-2.78 ( m, 1H), 4.35 (dd, $J=6.9,3.8 \mathrm{~Hz}, 1 \mathrm{H}), 4.36-4.40(\mathrm{~m}, 2 \mathrm{H}), 4.93(\mathrm{~d}, J=13.0$ $\mathrm{Hz}, 1 \mathrm{H}), 5.04(\mathrm{~d}, J=13.1 \mathrm{~Hz}, 1 \mathrm{H}), 5.24-5.30(\mathrm{~m}, 1 \mathrm{H}), 6.35(\mathrm{dd}, J=11.9,6.4 \mathrm{~Hz}, 1 \mathrm{H}), 7.35$ $(\mathrm{d}, J=7.8 \mathrm{~Hz}, 2 \mathrm{H}), 7.70(\mathrm{~d}, J=8.1 \mathrm{~Hz}, 2 \mathrm{H}), 8.40(\mathrm{~s}, 1 \mathrm{H}), 8.60(\mathrm{~s}, 1 \mathrm{H})$.

2',3',5'-Tri- $\boldsymbol{O}$-acetyl-5-(2-tosylacetyl)uridine $\quad \mathbf{( 5 0 b )}$ Treatment of protected 5ethynyluridine 5 (36 mg, $0.09 \mathrm{mmol})$ with $p$-toluenesufinic acid $(78 \mathrm{mg}, 0.5 \mathrm{mmol})$ and pyridine $(40 \mu \mathrm{L}, 39.2 \mathrm{mg}, 0.5 \mathrm{mmol}$ ) in the presence of air (balloon) and column chromatography (Hexane/EA ; 60:40 $\rightarrow$ 40:60) gave 50b (9 mg, 20\%) as white solid: ${ }^{1} \mathrm{H}$ $\operatorname{NMR}\left(\mathrm{CDCl}_{3}\right) \delta 2.11(\mathrm{~s}, 3 \mathrm{H}), 2.14(\mathrm{~s}, 3 \mathrm{H}), 2.19(\mathrm{~s}, 3 \mathrm{H}), 2.45(\mathrm{~s}, 3 \mathrm{H}), 4.35(\mathrm{ddd}, J=12.1,6.9$, 
$3.8 \mathrm{~Hz}, 2 \mathrm{H}), 4.40-4.44(\mathrm{~m}, 1 \mathrm{H}), 4.93(\mathrm{~d}, J=13.3 \mathrm{~Hz}, 1 \mathrm{H}), 5.06(\mathrm{~d}, J=13.3 \mathrm{~Hz}, 1 \mathrm{H}), 5.33-$ $5.38(\mathrm{~m}, 1 \mathrm{H}), 6.35(\mathrm{~d}, J=4.5 \mathrm{~Hz}, 1 \mathrm{H}), 7.35(\mathrm{~d}, J=8.0 \mathrm{~Hz}, 2 \mathrm{H}), 7.80(\mathrm{~d}, J=8.3 \mathrm{~Hz}, 2 \mathrm{H}), 8.50$ $(\mathrm{s}, 1 \mathrm{H}), 8.65(\mathrm{~s}, 1 \mathrm{H})$

\section{5-(2-Tosylacetyl)uracil/cytosine nucleosides (51-52 and 58-59). Procedure D.}

Acetyl protected (8 and 19-20) or unprotected (9-10) 5-(1-chloro-2-tosylvinyl)pyrimidine nucleosides were dissolved in methanolic ammonia and the resulting mixtures were stirred at $0{ }^{\circ} \mathrm{C} \rightarrow \mathrm{r.t}$; The volatiles were evaporated and the residue was dissolved in $4 \mathrm{~mL} \mathrm{CH}_{3} \mathrm{CN}$. The solution was acidified $(\mathrm{pH} \sim 4)$ by adding dil. $\mathrm{HCl}(\mathrm{aq})$ and stirred for $2 \mathrm{~h}$. After neutralizing the solution with dil. $\mathrm{NaOH}(\mathrm{aq})$, the volatiles were evaporated and the residue was column chromatographed to give the products (51-52 and 58-59).

5-(2-Tosylacetyl)-2'-deoxyuridine (51). Treatment of 9 (96 $\mathrm{mg}, 0.21 \mathrm{mmol}$ ) with methanolic ammonia ( $3 \mathrm{~mL})$ for $2 \mathrm{~h}$ and subsequent acid hydrolysis as described in procedure D followed by column chromatography $\left(\mathrm{CHCl}_{3} / \mathrm{MeOH} ; 100: 0 \rightarrow\right.$ 95:5) gave 51 (68 mg, 72\%) as white solid: ${ }^{1} \mathrm{H}$ NMR (DMSO- $\left.d_{6}\right) \delta 2.10-2.27$ (m, 2H, H2',2"), 2.40 (s, 3, Me), 3.51$3.63\left(\mathrm{~m}, 2 \mathrm{H}, \mathrm{H} 5^{\prime}, 5^{\prime \prime}\right), 3.87\left(\mathrm{q}, J=3.1 \mathrm{~Hz}, 1 \mathrm{H}, \mathrm{H} 4{ }^{\prime}\right), 4.23\left(\mathrm{q}, J=3.4 \mathrm{~Hz}, 1 \mathrm{H}, \mathrm{H} 3^{\prime}\right), 5.10(\mathrm{t}, J=$ $\left.4.5 \mathrm{~Hz}, 1 \mathrm{H}, 5^{\prime} \mathrm{OH}\right), 5.15\left(\mathrm{~s}, 2 \mathrm{H}, \alpha-\mathrm{CH}_{2}\right), 5.30(\mathrm{~d}, J=4.1 \mathrm{~Hz}, 1 \mathrm{H}, 3 \mathrm{OH}), 6.06(\mathrm{t}, J=6.3 \mathrm{~Hz}$, 1H, H1'), 7.42 (d, J=8.2 Hz, 2H, Ar), $7.74(\mathrm{~d}, J=8.1 \mathrm{~Hz}, 2 \mathrm{H}, \mathrm{Ar}), 8.68$ (s, 1H, H6), 11.80 (s, $1 \mathrm{H}, \mathrm{NH}) ;{ }^{13} \mathrm{C}$ NMR (DMSO- $\left.d_{6}\right) \delta 21.0,41.0,60.5,64.0,70.0,86.0,88.0,110.5,128.0,130.0$, 137.0, 144.0, 148.0, 149.0, 161.0, 184.0; HRMS calcd for $\mathrm{C}_{18} \mathrm{H}_{20} \mathrm{~N}_{2} \mathrm{NaO}_{8} \mathrm{~S}[\mathrm{M}+\mathrm{Na}]^{+}$for 447.0833, found 447.0874

5-(2-Tosylacetyl)uridine (52). Treatment of 10 (96 $\mathrm{mg}, 0.21 \mathrm{mmol})$ with methanolic ammonia $(3 \mathrm{~mL})$ for $2 \mathrm{~h}$ and subsequent acid hydrolysis as described in procedure $\mathrm{D}$ followed by column chromatography $\left(\mathrm{CHCl}_{3} / \mathrm{MeOH} ; 100: 0 \rightarrow 95: 5\right)$ gave $\mathbf{5 2}(65 \mathrm{mg}, 70 \%)$ as white 
solid: ${ }^{1} \mathrm{H}$ NMR (DMSO- $\left.d_{6}\right) \delta 2.40$ (s, 3H, Me), 3.55-3.75 (m, , $\left.1 \mathrm{H}, \mathrm{H} 5{ }^{\prime} 5 "\right), 3.93$ (q, $J=3.2$ Hz, 1H, H4'), 3.95 (t, $\left.J=4.9 \mathrm{~Hz}, 1 \mathrm{H}, \mathrm{H} 3^{\prime}\right), 4.08$ (t, $J=5.0 \mathrm{~Hz}, 1 \mathrm{H}, \mathrm{H2}$ ), 5.12 (t, $J=4.5 \mathrm{~Hz}$, $\left.1 \mathrm{H}, 5{ }^{\prime} \mathrm{OH}\right), 5.14\left(\mathrm{~s}, 2 \mathrm{H}, \alpha-\mathrm{CH}_{2}\right), 5.21\left(\mathrm{~d}, J=4.1 \mathrm{~Hz}, 1 \mathrm{H}, 3{ }^{\prime} \mathrm{OH}\right), 5.51(\mathrm{~d}, J=4.9 \mathrm{~Hz}, 1 \mathrm{H}$, $\left.2^{\prime} \mathrm{OH}\right), 5.75\left(\mathrm{~d}, J=2.2 \mathrm{~Hz}, 1 \mathrm{H}, \mathrm{H1} 1^{\prime}\right), 7.42(\mathrm{~d}, J=7.8 \mathrm{~Hz}, 2 \mathrm{H}, \mathrm{Ar}), 7.74(\mathrm{~d}, J=7.8 \mathrm{~Hz}, 2 \mathrm{H}$, Ar), $8.80(\mathrm{~s}, 1 \mathrm{H}, \mathrm{H} 6), 11.85(\mathrm{~s}, 1 \mathrm{H}, \mathrm{NH}) ;{ }^{13} \mathrm{C}$ NMR (DMSO- $\left.d_{6}\right) \delta$ 21.0, 60.0, 64.2, 69.5, 75.0, 85.0, 89.5, 111.0, 128.0, 130.0, 137.0, 144.5, 148.0, 149.5, 161.0, 185.0

5-(2-Tosylacetyl)-2'-deoxycytidine (58). Treatment of acetyl protected ( $\beta$-chloro) vinyl sulfone $19(150 \mathrm{mg}, 0.28 \mathrm{mmol})$ with methanolic ammonia $(5 \mathrm{~mL})$ for $12 \mathrm{~h}$ and subsequent acid hydrolysis as described in procedure $\mathrm{D}$ followed by column chromatography $\left(\mathrm{CHCl}_{3} / \mathrm{MeOH} ; 100: 0 \rightarrow\right.$ 95:10) gave $\mathbf{5 8}(70 \mathrm{mg}, 59 \%)$ as white solid: ${ }^{1} \mathrm{H}$ NMR (DMSO- $\left.d_{6}\right)$ $\delta$ 2.05-2.10 (m, 1H, H2'), 2.30 (ddd, $J=13.2,8.2,2.1 \mathrm{~Hz}, 1 \mathrm{H}, \mathrm{H} 2 "), 2.40$ (s, 3H, Me), 3.623.68 (m, 1H, H5'), 3.70-3.76 (m, 1H, H5"), 3.92 (q, $J=3.4 \mathrm{~Hz}, 1 \mathrm{H}, \mathrm{H} 4$ '), 4.30 (quint, $J=4.6$ Hz, 1H, H3'), $4.86(\mathrm{~d}, J=14.1 \mathrm{~Hz}, 1 \mathrm{H}, \alpha-\mathrm{CH}), 4.95(\mathrm{~d}, J=14.1 \mathrm{~Hz}, 1 \mathrm{H}, \alpha-\mathrm{CH}), 5.29(\mathrm{~d}, J=$ $\left.4.4 \mathrm{~Hz}, 1 \mathrm{H}, 3^{\prime} \mathrm{OH}\right), 5.34\left(\mathrm{t}, J=5.3 \mathrm{~Hz}, 1 \mathrm{H}, 5^{\prime} \mathrm{OH}\right), 6.09\left(\mathrm{t}, J=5.9 \mathrm{~Hz}, 1 \mathrm{H}, \mathrm{H}^{\prime}\right), 7.45(\mathrm{~d}, J=$ $8.3 \mathrm{~Hz}, 2 \mathrm{H}, \mathrm{Ar}), 7.75$ ( d, $J=7.8 \mathrm{~Hz}, 2 \mathrm{H}, \mathrm{Ar}), 8.10$ (d, $\left.J=5.4 \mathrm{~Hz}, 2 \mathrm{H}, \mathrm{NH}_{2}\right), 9.02$ (s, 1H, H6); ${ }^{13}$ C NMR (DMSO- $\left.d_{6}\right) \delta 21.0,41.5,61.0,62.5,69.5,86.0,88.0,103.0,128.0,130.0,136.0$, 144.5, 152.0, 152.5, 163.0, 185.5; HRMS calcd for $\mathrm{C}_{18} \mathrm{H}_{22} \mathrm{~N}_{3} \mathrm{O}_{7} \mathrm{~S}[\mathrm{M}+\mathrm{H}]^{+} 424.1178$, found 424.1176

5-(2-Tosylacetyl)cytidine (59). Treatment of acetyl protected ( $\beta$-chloro) vinyl sulfone 20 (35 mg, $0.06 \mathrm{mmol}$ ) with methanolic ammonia $(4 \mathrm{~mL})$ for $12 \mathrm{~h}$ and subsequent acid hydrolysis as described in procedure D followed by column chromatography $\left(\mathrm{CHCl}_{3} / \mathrm{MeOH}\right.$; 100:0 $\rightarrow$ 95:10) gave $\mathbf{5 9}(17 \mathrm{mg}, 64 \%)$ as white solid: ${ }^{1} \mathrm{H}$ NMR (DMSO- $\left.d_{6}\right) \delta 2.40(\mathrm{~s}, 3 \mathrm{H}$, Me), 3.68 (ddd, $J=12.5,5.2,3.0 \mathrm{~Hz}, 1 \mathrm{H}, \mathrm{H} 5$ '), 3.85 (ddd, $J=12.1,4.5,2.3 \mathrm{~Hz}, 1 \mathrm{H}, \mathrm{H} 5 ")$, 
$3.95\left(\mathrm{q}, J=3.4 \mathrm{~Hz}, 1 \mathrm{H}, \mathrm{H} 4{ }^{\prime}\right), 3.98-4.02\left(\mathrm{~m}, 1 \mathrm{H}, \mathrm{H} 3^{\prime}\right) 4.03-4.09\left(\mathrm{~m}, 1 \mathrm{H}, \mathrm{H} 2^{\prime}\right), 4.80$ (d, $J=14.1$ $\mathrm{Hz}, 1 \mathrm{H}, \alpha-\mathrm{CH}), 4.95(\mathrm{~d}, J=14.1 \mathrm{~Hz}, 1 \mathrm{H}, \alpha-\mathrm{CH}), 5.05\left(\mathrm{~d}, J=6.5 \mathrm{~Hz}, 1 \mathrm{H}, 3^{\prime} \mathrm{OH}\right), 5.45(\mathrm{t}, J=$ $\left.5.0 \mathrm{~Hz}, 1 \mathrm{H}, 5^{\prime} \mathrm{OH}\right), 5.58\left(\mathrm{~d}, J=4.8 \mathrm{~Hz}, 1 \mathrm{H}, 2^{\prime} \mathrm{OH}\right), 5.71\left(\mathrm{~d}, J=1.9 \mathrm{~Hz}, 1 \mathrm{H}, \mathrm{H} 1^{\prime}\right), 7.43(\mathrm{~d}, J=$ $8.3 \mathrm{~Hz}, 2 \mathrm{H}, \mathrm{Ar}), 7.74(\mathrm{~d}, J=8.2 \mathrm{~Hz}, 2 \mathrm{H}, \mathrm{Ar}), 8.06(\mathrm{~d}, J=3.2 \mathrm{~Hz}, 1 \mathrm{H}, \mathrm{NH}), 8.13(\mathrm{~d}, J=3.2$ $\mathrm{Hz}, 1 \mathrm{H}, \mathrm{NH}), 9.05(\mathrm{~s}, 1 \mathrm{H}, \mathrm{H} 6) ;{ }^{13} \mathrm{C}$ NMR (DMSO- $\left.d_{6}\right) \delta 21.0,60.0,62.5,68.3,74.0,84.0$, $91.0,103.5,128.0,130.0,136.0,145.0,152.0,152.5,162.5,185.5$

Incorporation of electrophiles at the $\alpha$-carbon of $\beta$-keto sulfone moiety of pyridmidine nucleoside analogues (53-56 and 60-62). Procedure E. 5-( $\beta$-keto)sulfones of uracil/cytosine nucleoside were dissolved in $1 \mathrm{~mL} \mathrm{MeOH}$. Then $5 \mathrm{M} \mathrm{NaOH} / \mathrm{H}_{2} \mathrm{O}$ solution (2 equiv.) were added and the solution was stirred for $20 \mathrm{~min}$. Finally, 1.2 equiv. of the electrophile source $(\mathrm{R}-\mathrm{X})$ was added and the resulting solution was stirred at ambient temperature. The solution was neutralized by adding dil. $\mathrm{HCl}$ and volatiles were evaporated. The residue was column chromatographed to give the desired products (53-56 and 60-62).

5-(2-Benzyl-2-tosylacetyl)-2'-deoxyuridine (53). Treatment of $\mathbf{5 1}(18 \mathrm{mg}, 0.042 \mathrm{mmol})$ with $\mathrm{NaOH}(\mathrm{aq})(16 \mu \mathrm{L}, 3.36 \mathrm{mg}, 0.084 \mathrm{mmol})$, and benzyl bromide $(10 \mu \mathrm{L}, 14.4 \mathrm{mg}, 0.05$ mmol) for $3 \mathrm{~h}$ as described in procedure $\mathrm{E}$ followed by column chromatography $\left(\mathrm{CHCl}_{3} / \mathrm{MeOH} ; 100: 0 \rightarrow 95: 5\right)$ gave $\mathbf{5 3}$ as a (50/50) mixture of diastereomers $(6 \mathrm{mg}, 28 \%)$ along with byproducts. ${ }^{1} \mathrm{H}$ NMR (DMSO- $\left.d_{6}\right) \delta$ 2.05-2.20 (m, 1.0, H2'), 2.22-2.32 (m, 1.0, H2"), 2.40 (s, 1.5, Me), 2.41 (s, 1.5, Me), 3.25-3.30 (m, 1, Bn), 3.10-3.20 (m, 1.0, Bn), 3.543.68 (m, 2.0, H5',5"), 3.88 (q, $J=3.2 \mathrm{~Hz}, 1.0, \mathrm{H} 4$ '), 4.20 (dd, $J=9.2,4.2 \mathrm{~Hz}, 0.5, \mathrm{H} 3$ '), 4.25 (dd, $\left.J=9.2,4.2 \mathrm{~Hz}, 0.5, \mathrm{H}^{\prime}\right), 5.12-5.18\left(\mathrm{~m}, 1.0,5^{\prime} \mathrm{OH}\right), 5.28\left(\mathrm{~d}, J=4.3 \mathrm{~Hz}, 0.5,3^{\prime} \mathrm{OH}\right), 5.33$ (d, $\left.\left.J=4.3 \mathrm{~Hz}, 0.5,3^{\prime} \mathrm{OH}\right), 5.97(\mathrm{t}, J=6.2 \mathrm{~Hz}, 0.5, \mathrm{H1})^{\prime}\right), 6.06\left(\mathrm{t}, J=6.3 \mathrm{~Hz}, 0.5, \mathrm{H} 1^{\prime}\right), 6.52(\mathrm{t}$, $J=3.4 \mathrm{~Hz}, 0.5, \alpha-\mathrm{CH}), 6.56(\mathrm{t}, J=3.4 \mathrm{~Hz}, 0.5, \alpha-\mathrm{CH}), 7.05(\mathrm{~d}, J=7.1 \mathrm{~Hz}, 2.0, \mathrm{Ar}) 7.13(\mathrm{t}, J$ 
$=6.5 \mathrm{~Hz}, 1.0, \mathrm{Ar}), 7.18(\mathrm{t}, J=6.9 \mathrm{~Hz}, 2.0, \mathrm{Bn}) 7.42(\mathrm{~d}, J=7.9 \mathrm{~Hz}, 1.0, \mathrm{Ar}), 7.44(\mathrm{~d}, J=7.9$ Hz, 1.0, Ar), 7.67 (d, $J=8.1 \mathrm{~Hz}, 1.0, \mathrm{Ar}), 7.69$ (d, $J=8.1 \mathrm{~Hz}, 1.0, \mathrm{Ar}), 8.63$ (s, 0.5, H6), 8.70 (s, 0.5, H6), 11.50 (s, 1.0, NH); ${ }^{13} \mathrm{C}$ NMR (DMSO- $\left.d_{6}\right) \delta 21.0,31.3,31.6,40.5,40.9,54.8$, $60.7,60.8,69.9,86.0,86.5,88.0,88.2,111.0,111.4,126.6,128.4,128.5,128.6,128.8,128.9$, 129.6, 129.8, 134.5, 136.1, 136.2, 145.0, 145.1, 148.0, 148.1, 149.1, 149.2, 161.4, 161.5, 186.1, 186.2; HRMS calcd for $\mathrm{C}_{25} \mathrm{H}_{27} \mathrm{~N}_{2} \mathrm{O}_{8} \mathrm{~S}[\mathrm{M}+\mathrm{H}]^{+} 515.1488$, found 515.1437

5-(2-Methyl-2-tosylacetyl)-2'-deoxyuridine (54). Treatment of 51 (16 mg, $0.037 \mathrm{mmol})$ with $\mathrm{NaOH}(\mathrm{aq})(16 \mu \mathrm{L}, 2.96 \mathrm{mg}, 0.074 \mathrm{mmol})$, and methyl iodide (4.60 $\mu \mathrm{L}, 10.50 \mathrm{mg}, 0.074$ mmol) for $4 \mathrm{~h}$ as described in procedure $\mathrm{E}$ followed by column chromatography $\left(\mathrm{CHCl}_{3} / \mathrm{MeOH} ; 100: 0 \rightarrow\right.$ 95:5) gave $\mathbf{5 4}$ as a (50/50) mixture of diastereomers (5 $\left.\mathrm{mg}, 31 \%\right)$ and two byproducts. ${ }^{1} \mathrm{H}$ NMR (DMSO- $\left.d_{6}\right) \delta 1.32$ (t, $\left.J=7.4 \mathrm{~Hz}, 3.0\right), 2.10-2.18$ (m, 1.0, H2'), 2.20-2.30 (m, 1.0, H2"), 2.39 (s, 1.5, Me), 2.40 (s, 1.5, Me), 3.53-3.64 (m, 2.0, H5',5"), 3.87$3.92\left(\mathrm{~m}, 1 \mathrm{H}, \mathrm{H} 4^{\prime}\right), 4.21-4.29\left(\mathrm{~m}, 1.0, \mathrm{H} 3^{\prime}\right), 5.11-5.16\left(\mathrm{~m}, 1.0,5^{\prime} \mathrm{OH}\right), 5.30(\mathrm{~d}, J=4.3 \mathrm{~Hz}, 0.5$, $\left.3^{\prime} \mathrm{OH}\right), 5.33\left(\mathrm{~d}, J=4.3 \mathrm{~Hz}, 0.5,3^{\prime} \mathrm{OH}\right), 5.97(\mathrm{q}, J=6.5 \mathrm{~Hz}, 1.0, \alpha-\mathrm{CH}), 6.05(\mathrm{t}, J=6.3 \mathrm{~Hz}, 0.5$, H1' ), 6.11 (t, $J=6.4 \mathrm{~Hz}, 0.5, \mathrm{H1}$ '), 7.42 (t, $J=7.6 \mathrm{~Hz}, 2.0, \mathrm{Ar}), 7.65$ (d, $J=8.1 \mathrm{~Hz}, 1.0, \mathrm{Ar}$ ), $7.68(\mathrm{~d}, J=8.1 \mathrm{~Hz}, 1.0, \mathrm{Ar}), 8.71$ (s, 0.5, H6), 8.73 (s, 0.5, H6), $11.80(\mathrm{~s}, 1.0, \mathrm{NH}) ;{ }^{13} \mathrm{C}$ NMR (DMSO- $\left.d_{6}\right) \delta 11.0,11.2,21.1,40.8,41.0,60.8,60.9,65.5,70.0,86.0,86.5,88.0,88.1,111.0$ $111.2,128.8,128.9,129.6,129.8,145.0,145.1,148.0,148.1,149.1,149.2,161.3,161.4$, $186.1,187.8$

5-(2-Allyl-2-tosylacetyl)-2'-deoxyuridine (55). Treatment of $\mathbf{5 1}(18 \mathrm{mg}, 0.042 \mathrm{mmol})$ with $\mathrm{NaOH}(\mathrm{aq})(16 \mu \mathrm{L}, 3.36 \mathrm{mg}, 0.084 \mathrm{mmol})$, and Allyl bromide (6 $\mu \mathrm{L}, 8.38 \mathrm{mg}, 0.069$ mmol) for $4 \mathrm{~h}$ as described in procedure $\mathrm{E}$ followed by column chromatography $\left(\mathrm{CHCl}_{3} /\right.$ $\mathrm{MeOH} ; 100: 0 \rightarrow$ 95:5) gave $\mathbf{5 5}$ as a (52/48) mixture of diastereomers $(6 \mathrm{mg}, 31 \%)$ and two 
byproducts: ${ }^{1} \mathrm{H}$ NMR (DMSO- $\left.d_{6}\right) \delta$ 2.05-2.20 (m, 1.10, H2'), 2.22-2.35 (m, 0.90, H2"), 2.39 (s, 1.65, Me), 2.40 (s, 1.35, Me), 2.66-2.78 (m, 2.00, $\left.\mathrm{CH}_{2}\right), 3.56-3.53-3.68$ (m, 2.00, H5',5"), $3.89\left(\mathrm{q}, J=3.3 \mathrm{~Hz}, 1.00, \mathrm{H}^{\prime}\right), 4.21-4.29$ (m, 1.00, H3'), 4.93-5.01 (m, 1.65, allyl), 5.11-5.17 (m, 1.00, 5'OH), $5.30\left(\mathrm{~d}, J=4.3 \mathrm{~Hz}, 0.55,3^{\prime} \mathrm{OH}\right), 5.35\left(\mathrm{~d}, J=4.3 \mathrm{~Hz}, 0.45,3^{\prime} \mathrm{OH}\right), 5.55-5.66$ (m, 1.00, allyl), 6.05 (t, $\left.\left.J=6.2 \mathrm{~Hz}, 0.45, \mathrm{H1} 1^{\prime}\right), 6.10(\mathrm{t}, J=6.2 \mathrm{~Hz}, 0.55, \mathrm{H1})^{\prime}\right), 6.18$ (d, $J=2.6$ $\mathrm{Hz}, 0.55, \alpha-\mathrm{CH}), 6.21(\mathrm{~d}, J=2.6 \mathrm{~Hz}, 0.45, \alpha-\mathrm{CH}), 7.40(\mathrm{~d}, J=8.2 \mathrm{~Hz}, 1.10, \mathrm{Ar}), 7.44(\mathrm{~d}, J=$ $8.2 \mathrm{~Hz}, 0.90, \mathrm{Ar}), 7.65$ (d, $J=7.5 \mathrm{~Hz}, 2.00, \mathrm{Ar}), 8.71$ (s, 0.45, H6), 8.73 (s, 0.55, H6), 11.80 (s, 1.00, NH); ${ }^{13} \mathrm{C}$ NMR (DMSO- $\left.d_{6}\right) \delta 21.1,30.0,30.3,40.5,41.0,60.8,60.9,68.9,70.0,70.1$, 86.0, 86.5, 88.0, 88.1, 110.8, 111.2, 118.0, 129.0, 129.6, 129.9, 133.0, 134.5, 134.6, 148.0, $148.1,149.0,149.2,161.5,161.6,186.5,186.7$

5-(2-Allyl-2-tosylacetyl)uridine (56). Treatment of 51 (18 $\mathrm{mg}, 0.04 \mathrm{mmol})$ with $\mathrm{NaOH}(\mathrm{aq})(16 \mu \mathrm{L}, 3.36 \mathrm{mg}, 0.084 \mathrm{mmol})$, and allyl bromide $(6 \mu \mathrm{L}, 8.38 \mathrm{mg}, 0.069 \mathrm{mmol})$ for $4 \mathrm{~h}$ as described in procedure $\mathrm{E}$ followed by column chromatography $\left(\mathrm{CHCl}_{3} / \mathrm{MeOH} ; 100: 0\right.$ $\rightarrow$ 95:5) gave $\mathbf{5 6}$ as a (52/48) mixture of diastereomers (6 mg, 32\%) and two byproducts: ${ }^{1} \mathrm{H}$ NMR (DMSO- $\left.d_{6}\right) \delta 2.39$ (s, 0.48, Me), 2.40 (s, 0.52, Me), 2.66-2.78 (m, 2.00, allyl), 3.573.63 (m, 0.96, H5'), 3.69-3.77 (m, 1.04, H5"), 3.4 (q, $J=3.3 \mathrm{~Hz}, 1.00, \mathrm{H} 4$ '), 3.95-4.02 (m, 1.00, H3'), 4.03-4.09 (m, 1.00, H2'), 4.93-5.01 (m, 1.04, allyl), 4.93-5.10 (m, 0.96, allyl), 5.13 $\left(\mathrm{d}, J=5.3 \mathrm{~Hz}, 1.04,3^{\prime} \mathrm{OH}\right), 5.20\left(\mathrm{~d}, J=5.4 \mathrm{~Hz}, 0.96,3^{\prime} \mathrm{OH}\right), 5.23-5.28\left(\mathrm{~m}, 1.00,5{ }^{\prime} \mathrm{OH}\right), 5.48$ (d, $\left.J=5.3 \mathrm{~Hz}, 0.48,3^{\prime} \mathrm{OH}\right), 5.58\left(\mathrm{~d}, J=5.2 \mathrm{~Hz}, 0.52,3^{\prime} \mathrm{OH}\right), 5.59-5.67$ (m, 1.00, allyl), 5.71 (d, $J=3.7 \mathrm{~Hz}, 0.48, \mathrm{H1}$ '), $5.78\left(\mathrm{~d}, J=4.0 \mathrm{~Hz}, 0.52, \mathrm{H1} 1^{\prime}\right), 6.13-6.21(\mathrm{~m}, 1.00, \alpha-\mathrm{CH}), 7.42(\mathrm{~d}$, $J=8.2 \mathrm{~Hz}, 0.96, \mathrm{Ar}), 7.46(\mathrm{~d}, J=8.2 \mathrm{~Hz}, 1.04, \mathrm{Ar}), 7.65(\mathrm{~d}, J=7.1 \mathrm{~Hz}, 2.00, \mathrm{Ar}), 8.81(\mathrm{~s}$, 0.48, H6), 8.90 (s, 0.52, H6), $11.80(\mathrm{~s}, 1.00, \mathrm{NH}) ;{ }^{13} \mathrm{C}$ NMR (DMSO- $\left.d_{6}\right) \delta 21.1,30.0,30.1$, $60.0,60.2,68.8,69.0,69.2,69.6,74.4,74.6, \quad 85.0,85.3,89.2,89.6,111.2,111.4,117.6$ 
$128.8,129.0,129.8,130.0,133.0,135.4,145.0,148.5,148.8,149.4,149.6,161.4,161.5$, $186.7,186.8$

5-(2-Benzyl-2-tosylacetyl)-2'-deoxycytidine (60). Treatment of $\mathbf{5 8}(18 \mathrm{mg}, 0.043 \mathrm{mmol})$ with $\mathrm{NaOH}(\mathrm{aq})(11 \mu \mathrm{L}, 2.2 \mathrm{mg}, 0.055 \mathrm{mmol})$, and benzyl bromide $(6.5 \mu \mathrm{L}, 9.4 \mathrm{mg}, 0.05$ mmol) for $8 \mathrm{~h}$ as described in procedure $\mathrm{E}$ followed by column chromatography $\left(\mathrm{CHCl}_{3} /\right.$ $\mathrm{MeOH} ; 100: 0 \rightarrow 95: 5)$ gave $\mathbf{6 0}$ as a (52/48) mixture of diastereomers $(15 \mathrm{mg}, 68 \%) .{ }^{1} \mathrm{H}$ NMR (DMSO- $\left.d_{6}\right) \delta$ 1.93-2.03 (m, 1.04, H2'), 2.22-2.30 (m, 0.96, H2"), 2.38 (s, 1.42, Me), 2.41 (s, 1.58, Me), 3.20-3.30 (m, 2.00, Bn), 3.54-3.68 (m, 2.00, H5',5"), 3.89 (q, $J=3.5 \mathrm{~Hz}$, $0.52, \mathrm{H} 4$ '), 4.00 (q, $J=3.5 \mathrm{~Hz}, 0.48, \mathrm{H} 4$ '), 4.20 (quint, $J=4.9 \mathrm{~Hz}, 0.52, \mathrm{H} 3$ '), 4.38 (quint, $J=$ $\left.4.7 \mathrm{~Hz}, 0.48, \mathrm{H}^{\prime}\right), 5.28\left(\mathrm{~d}, 0.52, J=4.6 \mathrm{~Hz}, 3^{\prime} \mathrm{OH}\right), 5.35\left(\mathrm{~d}, J=4.3 \mathrm{~Hz}, 0.48,3^{\prime} \mathrm{OH}\right), 5.48(\mathrm{dd}$, $J=11.3,3.6 \mathrm{~Hz}, 0.48, \alpha-\mathrm{CH}), 5.58(\mathrm{dd}, J=10.7,4.4 \mathrm{~Hz}, 0.48, \alpha-\mathrm{CH}),, 5.68(\mathrm{t}, J=4.6 \mathrm{~Hz}$, $\left.0.48,5^{\prime} \mathrm{OH}\right), 5.75\left(\mathrm{t}, J=4.9 \mathrm{~Hz}, 0.52,5{ }^{\prime} \mathrm{OH}\right), 5.94-6.20\left(\mathrm{~m}, 1.00, \mathrm{H}^{\prime}\right.$ ) , 7.08-7.23 (m, 5.00, Bn), $7.42(\mathrm{~d}, J=8.2 \mathrm{~Hz}, 1.04, \mathrm{Ar}), 7.46(\mathrm{~d}, J=8.2 \mathrm{~Hz}, 0.96$, Ar), 7.67 (d, $J=9.7 \mathrm{~Hz}, 0.52$, Ar) $7.71(\mathrm{~d}, J=8.8 \mathrm{~Hz}, 0.48, \mathrm{Ar}), 8.03\left(\mathrm{~d}, J=3.6 \mathrm{~Hz}, 0.52, \mathrm{NH}_{2}\right), 8.14(\mathrm{~d}, J=3.5 \mathrm{~Hz}, 0.48$, $\mathrm{NH}_{2}$ ), 8.92 (s, 0.48, H6), 9.06 (s, 0.52, H6); ${ }^{13} \mathrm{C}$ NMR (DMSO- $\left.d_{6}\right) \delta 21.0,31.8,32.2,41.4$, $41.6,60.5,60.8,68.5,69.0,69.4,69.6,69.8,86.0,86.8,87.6,88.0,104.0,104.8,126.7,126.9$, $128.4,128.5,128.6,128.7,128.8,128.9,129.8,129.9,133.7,133.8,135.6,135.8,145.1$, $145.3,151.0,151.2,152.0,162.0,162.4,187.4,188.0$

5-(2-Methyl-2-tosylacetyl)-2'-deoxycytidine (61). Treatment of $\mathbf{5 8}$ (18 $\mathrm{mg}, 0.043 \mathrm{mmol})$ with $\mathrm{NaOH}(\mathrm{aq})(20 \mu \mathrm{L}, 4.0 \mathrm{mg}, 0.1 \mathrm{mmol})$, and benzyl bromide $(7.5 \mu \mathrm{L}, 9.4 \mathrm{mg}, 0.086 \mathrm{mmol})$ for $24 \mathrm{~h}$ as described in procedure $\mathrm{E}$ followed by column chromatography $\left(\mathrm{CHCl}_{3} / \mathrm{MeOH}\right.$; 100: $0 \rightarrow 95: 5)$ gave 61 as a $(52 / 48)$ mixture of diastereomers $(15 \mathrm{mg}, 68 \%) .{ }^{1} \mathrm{H}$ NMR $\left(\mathrm{DMSO}_{-1}\right) \delta 1.33\left(\mathrm{~d}, J=6.5 \mathrm{~Hz}, 1.44, \mathrm{CH}_{3}\right), 1.37\left(\mathrm{~d}, J=6.5 \mathrm{~Hz}, 1.56, \mathrm{CH}_{3}\right), 2.03-2.18(\mathrm{~m}$, 
0.96, H2'), 2.28-2.35 (m, 1.04, H2"), 2.40 (s, 3.00, Me), 3.60-3.95 (m, 2.00, H4' \& H5'5"), 4.20 (quint, $0.52, \mathrm{H}^{\prime}$ ), 4.39 (q, $J=3.5 \mathrm{~Hz}, 0.52, \mathrm{H} 4$ '), 4.00 (q, $J=3.5 \mathrm{~Hz}, 0.48, \mathrm{H} 4$ '), 4.20 (quint, $J=4.8 \mathrm{~Hz}, 0.52, \mathrm{H} 3$ '), 4.39 (quint, $J=4.8 \mathrm{~Hz}, 0.48, \mathrm{H} 3$ '), 5.16-5.28 (m, 1.00, $\alpha-\mathrm{CH}$ ), 5.30-5.45 (m, 2.00, 3' \& 5'OH), $6.00\left(\mathrm{t}, J=4.8 \mathrm{~Hz}, 0.52, \mathrm{H} 1^{\prime}\right), 6.15\left(\mathrm{t}, J=5.5 \mathrm{~Hz}, 0.48, \mathrm{H} 1^{\prime}\right)$, $7.42(\mathrm{~d}, J=7.8 \mathrm{~Hz}, 1.04, \mathrm{Ar}), 7.46(\mathrm{~d}, J=7.8 \mathrm{~Hz}, 0.96$, Ar), 7.62 (d, J=8.2 Hz, 1.04, Ar), $7.66(\mathrm{~d}, J=8.2 \mathrm{~Hz}, 0.96, \mathrm{Ar}), 8.05-8.12\left(\mathrm{~m}, 0.52, \mathrm{NH}_{2}\right), 8.22\left(\mathrm{~d}, J=3.5 \mathrm{~Hz}, 0.48, \mathrm{NH}_{2}\right), 9.08$

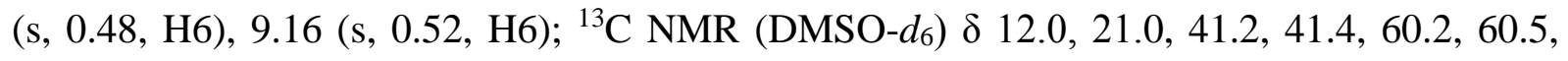
$63.3,64.1,68.8,69.0$, , 86.0, 86.8, 87.6, 88.1, 104.0,104.5, 129.0, 129.2, 130.0, 130.5, 133.4, $133.7,145.1,145.3,151.8,152.0,152.4,162.8,163.0,189.0,189.2$

5-(2-Benzyl-2-tosylacetyl)cytidine (62). Treatment of 59 (15 mg, $0.034 \mathrm{mmol})$ with $\mathrm{NaOH}(\mathrm{aq})(13.6 \mu \mathrm{L}, 2.7 \mathrm{mg}, 0.068 \mathrm{mmol})$, and benzyl bromide $(8.5 \mu \mathrm{L}, 11.6 \mathrm{mg}, 0.068$ mmol) for $8 \mathrm{~h}$ as described in procedure $\mathrm{E}$ followed by column chromatography $\left(\mathrm{CHCl}_{3} /\right.$ $\mathrm{MeOH} ; 100: 0 \rightarrow 95: 5)$ gave 62 as a (54/46) mixture of diastereomers $(12 \mathrm{mg}, 67 \%) .{ }^{1} \mathrm{H}$ NMR (DMSO-d $) \delta 2.38(\mathrm{~s}, 1.62, \mathrm{Me}), 2.40$ (s, 1.38, Me), 3.15-3.30 (m, 2.00, Bn), 3.72-3.90 (m, 2.00, H5',5"), 3.91-3.97 (m, , 1.00, H4'), 3.98-4.03 (m, 1.00, H3'), 4.04-4.20 (m, 1.00, $\left.\mathrm{H}^{\prime}\right), 5.28\left(\mathrm{~d}, J=4.6 \mathrm{~Hz}, 0.54,3^{\prime} \mathrm{OH}\right), 5.05\left(\mathrm{~d}, J=6.3 \mathrm{~Hz}, 0.46,3^{\prime} \mathrm{OH}\right), 5.20(\mathrm{~d}, J=3.6 \mathrm{~Hz}$, 0.54, 3'OH), 5.45-5.52 (m, 1.00, 2'OH ), 5.53-5.58 (m, 1.00, 1'), 5.59-5.63 (m, 1.00, $\alpha-\mathrm{CH})$, 5.72-5.88 (m, 1.00, 5'OH ), 7.09-7.23 (m, 5.00, Bn), $7.42(\mathrm{~d}, J=8.3 \mathrm{~Hz}, 1.08$, Ar), $7.46(\mathrm{~d}, J=$ 8.2 Hz, 0.92, Ar), 7.66 (d, $J=8.2 \mathrm{~Hz}, 1.08$, Ar), 7.69 (d, $J=8.2 \mathrm{~Hz}, 0.92$, Ar), 7.98-8.08 (m, $\left.1.08, \mathrm{NH}_{2}\right), 8.15\left(\mathrm{~d}, J=3.6 \mathrm{~Hz}, 0.92, \mathrm{NH}_{2}\right), 8.90(\mathrm{~s}, 0.54, \mathrm{H} 6), 9.06(\mathrm{~s}, 0.46, \mathrm{H} 6) ;{ }^{13} \mathrm{C} \mathrm{NMR}$ $\left(\mathrm{DMSO}-d_{6}\right) \delta 21.0,31.8,32.0,59.4,60.0,67.5,68.2,68.3,68.5,69.2,74.8,75.0,79.2,83.8$, $84.2,90.6,91.4,104.1,104.7,126.6,126.9,128.4,128.5,128.6,128.7,128.8,128.9,129.8$, 
130.1, 133.7, 134.1, 135.6, 135.7, 145.1, 145.2, 151.0, 151.5, 152.0, 162.4, 162.6, 187.4, 188.0

5-(2-Iodo-2-tosylacetyl)-2'-deoxyuridine (56). Method A. ( $\beta$-Keto)sulfone analogue 51 (18 mg, $0.042 \mathrm{mmol}$ ) was dissolved in $1 \mathrm{~mL} \mathrm{MeOH}$. Then, $\mathrm{NaOH}(\mathrm{aq})(8.4 \mu \mathrm{L}, 1.68 \mathrm{mg}$, $0.042 \mathrm{mmol}$ ) was added into the solution and was stirred for $30 \mathrm{~min}$. Later, iodine monochloride ( $42 \mu \mathrm{L}, 6.18 \mathrm{mg}, 0.042 \mathrm{mmol}$ ) was added into solution and the resulting mixtures were stirred for $3 \mathrm{~h}$. The solution was neutralized by adding dil. $\mathrm{HCl}$ and volatiles were evaporated. The residue was column chromatographed $\left(\mathrm{CHCl}_{3} / \mathrm{MeOH} ; 100: 0 \rightarrow 95: 5\right)$ to afford 56 as a (50/50) mixture of diastereomers $(8 \mathrm{mg}, 35 \%) .{ }^{1} \mathrm{H}$ NMR (DMSO- $\left.d_{6}\right) \delta 2.08$ 2.30 (m, 2H, H2'2"), 2.40 (s, 3H, Me), 3.55-3.75 (m, 2H, H5',5"), 3.85 (q, $J=3.4 \mathrm{~Hz}, 1 \mathrm{H}$, $\left.\mathrm{H}^{\prime}\right), 4.22\left(\mathrm{~m}, 1 \mathrm{H}, \mathrm{H} 3^{\prime}\right), 5.13\left(\mathrm{t}, J=4.6 \mathrm{~Hz}, 0.5 \mathrm{H}, 5^{\prime} \mathrm{OH}\right), 5.17$ (t, $\left.J=4.5 \mathrm{~Hz}, 0.5 \mathrm{H}, 5^{\prime} \mathrm{OH}\right)$, $5.28\left(\mathrm{~d}, J=4.4 \mathrm{~Hz}, 0.5 \mathrm{H}, 3^{\prime} \mathrm{OH}\right), 5.31\left(\mathrm{~d}, J=4.6 \mathrm{~Hz}, 0.5 \mathrm{H}, 3^{\prime} \mathrm{OH}\right), 5.58-6.10\left(\mathrm{~m}, 1 \mathrm{H}, \mathrm{H} 1^{\prime}\right)$, $7.30(\mathrm{~s}, 1 \mathrm{H}, \alpha-\mathrm{CH}), 7.45(\mathrm{~d}, J=8.1 \mathrm{~Hz}, 2 \mathrm{H}, \mathrm{Ar}), 7.75(\mathrm{~d}, J=8.1 \mathrm{~Hz}, 2 \mathrm{H}, \mathrm{Ar}), 8.80$ (s, $0.5 \mathrm{H}$, H6), 8.82 (s, 0.5H, H6), 11.90 (s, 1H, NH); ${ }^{13} \mathrm{C}$ NMR (DMSO-d $)^{\text {) }} \delta 21.1,, 40.5,41.0,60.8$, $60.9,68.9,69.9,70.0,86.3,86.5,88.0,88.1,107.7,107.9,128.5,129.5,129.6,129.7,129.8$ $133.3,133.4,134.5,134.6,145.0,145.2,150.0,150.2,161.0,161.1,186.5$

Method B. ( $\beta$-Keto)sulfone $51(40 \mathrm{mg}, 0.094 \mathrm{mmol})$ was taken in a round bottom flask containing $0.3 \mathrm{~mL}$ of acetic acid. Then iodine $(15 \mathrm{mg}, 0.056 \mathrm{mmol})$ and $50 \% \mathrm{H}_{2} \mathrm{O}_{2}(\mathrm{aq})(60$ $\mu \mathrm{L}, 0.94 \mathrm{mmol}$ ) were sequentially added into the flask. The resulting mixtures were stirred for $1 \mathrm{~h}$ at ambient temperature. The volatiles were evaporated and column chromatography $\left(\mathrm{CHCl}_{3} / \mathrm{MeOH} ; 100: 0 \rightarrow\right.$ 95:5) afforded 5-( $\alpha$-iodo- $\beta$-keto)sulfone 56 ( $\left.21 \mathrm{mg}, 41 \%\right)$.

5-(2-Propanethio-2-tosylacetyl)-2'-deoxyuridine (57). The 5-( $\alpha$-iodo- $\beta$-keto)sulfone 56 (10 $\mathrm{mg}, 0.018 \mathrm{mmol}$ ) was dissolved in $1 \mathrm{~mL}$ of $\mathrm{MeOH}$. Then 1:1 mixture of propanethiol and 
$\operatorname{TEA}(8.5 \mu \mathrm{L}, 6.8 \mathrm{mg}, 0.076 \mathrm{mmol})$ was added into a stirring solution of $\mathbf{5 6}$ at ambient temperature for $24 \mathrm{~h}$. The volatiles were evaporated and column chromatography $\left(\mathrm{CHCl}_{3} /\right.$ $\mathrm{MeOH} ; 100: 0 \rightarrow$ 95:5) afforded $\mathbf{5 7}$ as a (50/50) mixture of diastereomers $(2 \mathrm{mg}, 22 \%) .{ }^{1} \mathrm{H}$ NMR (DMSO- $\left.d_{6}\right) \delta$ 2.08-2.30 (m, 2H, H2'2"), 2.40 (s, 3H, Me), 3.55-3.75 (m, 2H, H5',5"), $3.85\left(\mathrm{q}, J=3.4 \mathrm{~Hz}, 1 \mathrm{H}, \mathrm{H} 4^{\prime}\right), 4.22\left(\mathrm{~m}, 1 \mathrm{H}, \mathrm{H} 3^{\prime}\right), 5.13\left(\mathrm{t}, J=4.6 \mathrm{~Hz}, 0.5 \mathrm{H}, 5^{\prime} \mathrm{OH}\right), 5.17(\mathrm{t}, J=$ $\left.4.5 \mathrm{~Hz}, 0.5 \mathrm{H}, 5^{\prime} \mathrm{OH}\right), 5.28\left(\mathrm{~d}, J=4.4 \mathrm{~Hz}, 0.5 \mathrm{H}, 3^{\prime} \mathrm{OH}\right), 5.31\left(\mathrm{~d}, J=4.6 \mathrm{~Hz}, 0.5 \mathrm{H}, 3^{\prime} \mathrm{OH}\right), 5.58-$ $6.10\left(\mathrm{~m}, 1 \mathrm{H}, \mathrm{H} 1^{\prime}\right), 7.30(\mathrm{~s}, 1 \mathrm{H}, \alpha-\mathrm{CH}), 7.45(\mathrm{~d}, J=8.1 \mathrm{~Hz}, 2 \mathrm{H}, \mathrm{Ar}), 7.75(\mathrm{~d}, J=8.1 \mathrm{~Hz}, 2 \mathrm{H}$, Ar), 8.80 (s, 0.5H, H6), 8.82 (s, 0.5H, H6), $11.90(\mathrm{~s}, 1 \mathrm{H}, \mathrm{NH})$

8-(1-Chloro-2-tosylvinyl)adenine (67). Treatment of 8-ethynyl adenosine analogue 66 (100 mg, $0.198 \mathrm{mmol})$ with $p$-toluenesulfonyl hydrazide $(110.6 \mathrm{mg}, 0.594 \mathrm{mmol})$ in the presence of $\mathrm{FeCl}_{3} \cdot 6 \mathrm{H}_{2} \mathrm{O}(108 \mathrm{mg}, 0.396 \mathrm{mmol}$ ) by procedure A (column chromatography; $\left.\mathrm{CHCl}_{3} / \mathrm{MeOH} ; 100: 0 \rightarrow 95: 5\right)$ gave $67(30 \mathrm{mg}, 44 \%):{ }^{1} \mathrm{H}$ NMR (DMSO- $\left.d_{6}\right) \delta 2.40(\mathrm{~s}, 3 \mathrm{H}$ ), $7.45(\mathrm{~d}, J=7.9 \mathrm{~Hz}, 2 \mathrm{H}), 7.49(\mathrm{bs}, 2 \mathrm{H}), 7.81(\mathrm{~d}, J=8.2 \mathrm{~Hz}, 2 \mathrm{H}), 7.88(\mathrm{~s}, 1 \mathrm{H}), 8.18(\mathrm{~s}, 1 \mathrm{H})$, $13.6(\mathrm{~s}, 1 \mathrm{H}) ;{ }^{13} \mathrm{C}$ NMR (DMSO- $\left.d_{6}\right) \delta 21.2,119.4,128.1,129.8,135.2,136.4,139.6,145.0$, $149.0,150.7,153.0,156.2$.

3',5'-Bis-( $O$-tert-butyldimetylsilyl)-8-(1-iodo-2-tosylvinyl)-2' -deoxyadenosine

(68). TBDMS protected 8 ethynyl 2'-deoxyadenosine $66(200 \mathrm{mg}, 0.4 \mathrm{mmol})$ was dissolved in $\mathrm{CH}_{3} \mathrm{CN}$. Then, sodium salt of $p$-toluenesulfinic acid $(205.6 \mathrm{mg}, 1.2 \mathrm{mmol})$, iodine $(152.0 \mathrm{mg}$, $0.60 \mathrm{mmol})$, and sodium acetate $(49.2 \mathrm{mg}, 0.6 \mathrm{mmol})$ were sequentially added into the solution. The resulting mixtures were stirred at $80^{\circ} \mathrm{C}$ for $5 \mathrm{~h}$. The volatiles was evaporated and column chromatography (Hexane/EA; 70:30 $\rightarrow 50: 50)$ gave $\mathbf{6 8}(148 \mathrm{mg}, 48 \%)$ as pale yellow solid. ${ }^{1} \mathrm{H}$ NMR $\left(\mathrm{CDCl}_{3}\right) \delta 0.10(\mathrm{~s}, 6 \mathrm{H}), 0.15(\mathrm{~s}, 6 \mathrm{H}), 0.80(\mathrm{~s}, 9 \mathrm{H}), 0.90(\mathrm{~s}, 9 \mathrm{H}), 2.30-2.35(\mathrm{~m}$, 1H), $2.40(\mathrm{~s}, 3 \mathrm{H}), 3.45-3.55(\mathrm{~m}, 1 \mathrm{H}), 3.80(\mathrm{bs}, 1 \mathrm{H}), 4.00-4.10(\mathrm{~m}, 2 \mathrm{H}), 4.85(\mathrm{bs}, 1 \mathrm{H}), 5.85(\mathrm{~s}$, 
2H), $6.20(\mathrm{dd}, J=13.5,6.7 \mathrm{~Hz}, 1 \mathrm{H}), 7.24(\mathrm{~d}, J=8.1 \mathrm{~Hz}, 2 \mathrm{H}), 7.58(\mathrm{~s}, 1 \mathrm{H}), 7.68(\mathrm{bs}, 2 \mathrm{H}), 8.32$

$(\mathrm{s}, 1 \mathrm{H}) ;{ }^{13} \mathrm{C} \mathrm{NMR}\left(\mathrm{CDCl}_{3}\right) \delta-0.6,-0.5,-0.4,-0.3,18.0,18.5,22.0,26.0,38.0,63.0,73.0,86.0$, $88.0,120,128.3,130.0,136.0,146.0,147.5,150.0,153.0,156.0$.

$S$-[(E)-1-(2'-Deoxyuridin-5-yl)-2-tosylvinyl]-L-glutathione monophosphate (72). The 5'-monophosphate 69 (12 mg, $0.022 \mathrm{mmol})$ was added in $1 \mathrm{~mL}$ of methanol-water (50:50) co-solvent system. Then, L-glutathione $(8.9 \mathrm{mg}, 0.029 \mathrm{mmol})$ and triethylamine $(25.0 \mu \mathrm{L}$, $17.8 \mathrm{mg}, 0.176 \mathrm{mmol})$ were sequentially added into the solution. The resulting mixtures were stirred at ambient temperature for $4 \mathrm{~h}$. The volatiles were evaporated and sephadex column separation (TEAB buffer $0.1-0.3 \mathrm{M})$ gave $72(10 \mathrm{mg}, 57 \%)$ as white solid. $1 \mathrm{H}$ NMR $\left(\mathrm{D}_{2} \mathrm{O}\right) \delta$ $2.15(\mathrm{q}, J=7.4 \mathrm{~Hz}, 2 \mathrm{H}), 2.28-2.41(\mathrm{~m}, 2 \mathrm{H}), 2.44(\mathrm{~s}, 3 \mathrm{H}), 2.52(\mathrm{dt}, J=15.5,7.5 \mathrm{~Hz}, 2 \mathrm{H})$, 3.32-3.38 (m, 1H), 3.70-3.90 (m, 5H), $4.05(\mathrm{q}, J=3.9 \mathrm{~Hz}, 1 \mathrm{H}), 4.45(\mathrm{br}, 1 \mathrm{H}), 4.65-4.72(\mathrm{~m}$, 2H), $6.30(\mathrm{t}, J=6.4 \mathrm{~Hz}, 1 \mathrm{H}), 6.95(\mathrm{~s}, 1 \mathrm{H}), 7.42(\mathrm{~d}, J=8.2 \mathrm{~Hz}, 2 \mathrm{H}), 7.62(\mathrm{~d}, J=8.0 \mathrm{~Hz}, 2 \mathrm{H})$, $7.95(\mathrm{~s}, 1 \mathrm{H}) ;{ }^{13} \mathrm{C} \mathrm{NMR}\left(\mathrm{D}_{2} \mathrm{O}\right) \delta 20.8,26.2,31.5,33.5,39.5,42.5,52.0,54.0,59.0,64.0,85.0$ 86.0, 108.7 127.0, 130.0, 133.0, 136.0, 142.0, 146.3, 150.6, 161.8, 170.7, 174.0, 175.0, 176.2; ${ }^{31} \mathrm{P}$ NMR $\left(\mathrm{D}_{2} \mathrm{O}\right) \delta$ 3.75; HRMS calculated for $\mathrm{C}_{28} \mathrm{H}_{35} \mathrm{~N}_{5} \mathrm{NaO}_{13} \mathrm{~S}_{2}[\mathrm{M}+\mathrm{Na}]^{+} 736.1570$, found 736.1513

General procedure for the phosphorylation of 5-( $\beta$-chloro)vinyl and 5-( $\beta$ keto)sulfone of 2'-deoxyuridne, synthesis of 5'-triphosphates (71 and 74). Procedure F. The 5-( $\beta$-Chloro)vinyl sulfone 9 or 5-( $\beta$-keto)sulfone 51 and proton sponge were placed in a flame dry round bottom flask. $1 \mathrm{~mL}$ trimethyl phosphate was added into the flask and the mixtures were allowed to $\mathrm{cool}$ at $0{ }^{\circ} \mathrm{C}$ for $5 \mathrm{~min}$. $\mathrm{POCl}_{3}$ was added and the mixtures were stirred for $30 \mathrm{~min}$. at $0{ }^{\circ} \mathrm{C}$. Then TBAPP $0.5 \mathrm{M}$ solution in DMF and tributylamine were added sequentially and the resulting mixtures were stirred for $10 \mathrm{~min}$ at $0{ }^{\circ} \mathrm{C}$. The reactions were 
quenched by dropwise adding $2 \mathrm{M}$ TEAB buffer. The reaction mixtures were extracted with ethylacetate two times and the aqueous layer was collected. The volatiles were evaporated and the residue was column chromatographed using Sephadex as adsorbent and TEAB buffer as eluting solovent to afford product $\mathbf{7 1}$ or $\mathbf{7 4}$.

(E)-5-(1-Chloro-2-tosylvinyl)-2'-deoxyuridine triphosphate (71). Treatment of chlorovinyl sulfone 28 (30 mg, $0.067 \mathrm{mmol})$ solution in $0.5 \mathrm{~mL} \mathrm{PO}(\mathrm{OMe})_{3}$ with $\mathrm{POCl}_{3}(16$ $\mu \mathrm{L}, 26.2 \mathrm{mg}, 0.17 \mathrm{mmol})$ in the presence of proton sponge $(37 \mathrm{mg}, 0.172 \mathrm{mmol})$ and subsequent treatment of the mixtures with $0.5 \mathrm{M}$ TBAPP solution (700 $\mu \mathrm{L}, 192 \mathrm{mg}, 0.35$ mmol) and TBA (50 $\mu \mathrm{L}, 39 \mathrm{mg}, 0.21 \mathrm{mmol}$ ) by procedure $\mathrm{F}$ and column chromatography (TEAB buffer; $0.1 \mathrm{M} \rightarrow 0.5 \mathrm{M})$ afforded 5'-triphosphate $71(15 \mathrm{mg}, 32 \%) .{ }^{1} \mathrm{H}$ NMR $\left(\mathrm{D}_{2} \mathrm{O}\right) \delta$ 2.28-2.40 (m, 2H, H2',2"), 2.45 (s, 3H, $\left.\mathrm{CH}_{3}\right), 4.14-4.20$ (m, 2H, H5',5"), 4.15-4.28 (m, 1H, H4'), $4.62\left(\mathrm{dd}, J=5.7,2.9 \mathrm{~Hz}, \mathrm{H} 3^{\prime}\right), 6.28(\mathrm{t}, J=6.7 \mathrm{~Hz}, 1 \mathrm{H}, \mathrm{H1}$ '), $7.44(\mathrm{~d}, J=8.0 \mathrm{~Hz}, 2 \mathrm{H}, \mathrm{Ar})$, 7.45 (s, $1 \mathrm{H}$, vinyl), 7.65 (d, $J=8.2 \mathrm{~Hz}, 2 \mathrm{H}, \mathrm{Ar}), 8.20(\mathrm{~s}, 1 \mathrm{H}, \mathrm{H} 6) ;{ }^{13} \mathrm{C} \mathrm{NMR}\left(\mathrm{D}_{2} \mathrm{O}\right) \delta 21.0$ 39.0, 66.0, 71.0, 85.0, 86.0, 108.5, 128.0, 130.5, 135.0, 136.0, 141.0, 142.5, 146.0, 150.0, $161.0 ;{ }^{31} \mathrm{P}$ NMR $\left(\mathrm{D}_{2} \mathrm{O}\right) \delta-23.00(\beta-\mathrm{P}),-11.50(\alpha-\mathrm{P}),-10.50(\gamma-\mathrm{P})$; HRMS calcd for $\mathrm{C}_{18} \mathrm{H}_{21} \mathrm{ClN}_{2} \mathrm{O}_{6} \mathrm{P}_{3} \mathrm{~S}[\mathrm{M}-\mathrm{H}]^{-680.9513, ~ f o u n d ~} 680.9517$

Note: Treatment of the crude product of the reaction between 9 and $\mathrm{POCl}_{3}$ with 2M TEAB buffer and column chromatography using Sephadex as adsorbent and TEAB buffer as eluting system $(0.1 \mathrm{M} \rightarrow 0.25 \mathrm{M})$ gave 5-(1-chloro-2-tosylvinyl)-2'-deoxyuridine phosphate 69.

5-(2-Tosylacetyl)-2'-deoxyuridine triphosphate (74). Treatmento of $\beta$-keto sulfone analogue $51(20 \mathrm{mg}, 0.047 \mathrm{mmol})$ solution in $0.5 \mathrm{~mL} \mathrm{PO}(\mathrm{OMe})_{3}$ with $\mathrm{POCl}_{3}(10 \mu \mathrm{L}, 16.4$ $\mathrm{mg}, 0.107 \mathrm{mmol})$ in the presence of proton sponge $(21 \mathrm{mg}, 0.097 \mathrm{mmol})$ and subsequent treatment of the mixtures with 0.M TBAPP solution $(400 \mu \mathrm{L}, 110 \mathrm{mg}, 0.2 \mathrm{mmol})$ and TBA 
(28 $\mu \mathrm{L}, 22 \mathrm{mg}, 0.118 \mathrm{mmol})$ by procedure $\mathrm{F}$ and column chromatography (TEAB buffer; $0.1 \mathrm{M} \rightarrow 0.5 \mathrm{M})$ afforded desired 5'-triphosphate $74(12 \mathrm{mg}, 38 \%) .{ }^{1} \mathrm{H}$ NMR $\left(\mathrm{D}_{2} \mathrm{O}\right) \delta 2.35-2.48$ (m, 2H, H2',2"), 2.45 (s, 3H, CH3), 3.58-3.68 (m, 2H, H5',5"), 4.21 (dd, J = 5.6, 4.0 Hz, 2H, $\alpha-$ $\mathrm{CH}_{2}$ ), 4.28 (br, 1H, H4'), 4.62 (dd, $J=6.0,2.8 \mathrm{~Hz}, \mathrm{H} 3$ '), 6.13 (t, $J=6.4 \mathrm{~Hz}, 1 \mathrm{H}, \mathrm{H} 1$ '), 7.47 (d, $J=8.0 \mathrm{~Hz}, 2 \mathrm{H}, \mathrm{Ar}), 7.65(\mathrm{~d}, J=8.0 \mathrm{~Hz}, 2 \mathrm{H}, \mathrm{Ar}), 8.46(\mathrm{~s}, 1 \mathrm{H}, \mathrm{H} 6) ;{ }^{13} \mathrm{C} \mathrm{NMR}\left(\mathrm{D}_{2} \mathrm{O}\right) \delta 21.0$ $39.0,59.0,65.0,71.0,87.0,88.0,112.0,128.0,130.5,134.0,148.0,149.0,150.0,161.0$, 185.0; ${ }^{31} \mathrm{P}$ NMR $\left(\mathrm{D}_{2} \mathrm{O}\right) \delta-23.50(\beta-\mathrm{P}),-11.70(\alpha-\mathrm{P}),-11.00(\gamma-\mathrm{P}) ;$ HRMS calcd for $\mathrm{C}_{18} \mathrm{H}_{22} \mathrm{~N}_{2} \mathrm{O}_{17} \mathrm{P}_{3} \mathrm{~S}[\mathrm{M}-\mathrm{H}]^{-}$662.9852, found 680.9859

General procedure for esterification of 5-( $\beta$-chloro)vinyl sulfone and 5heteroarlyated compounds. Synthesis of liphophilic analogues (75-76 and 82-85). Procedure G. 5-( $\beta$-Chloro)vinyl sulfone or 5-arlyated compound was dissolved in $1 \mathrm{~mL}$ DMF. Undecanoic anhydride and DMAP were sequentially added into the solution and stirred at ambient temperature. The volatiles were evaporated and the residue was partitioned between $\mathrm{CH}_{2} \mathrm{Cl}_{2}$ and $0.1 \mathrm{M} \mathrm{HCl} / \mathrm{H}_{2} \mathrm{O}$. The organic layer was washed with $\mathrm{NaHCO}_{3} / \mathrm{H}_{2} \mathrm{O}$ and brine and was column chromatographed to afford (75-76 and 82-85).

(E)-5'-O-Undecanoyl-5-(1-chloro-2-tosylvinyl)-2'-deoxyuridine (75). Treatment of 5( $\beta$-chloro)vinyl sulfone $9(25 \mathrm{mg}, 0.056 \mathrm{mmol})$ with undecanoic anhydride $(24 \mathrm{mg}, 0.067$ mmol) and DMAP (6.0 mg, $0.05 \mathrm{mmol})$ in DMF at ambient temperature for $2 \mathrm{~h}$ by Procedure $\mathrm{G}$ and column chromatography (hexane/EtOAc, 90:10 $\rightarrow$ 60:40) afforded 75 (15 mg, 45\%): ${ }^{1} \mathrm{H}$ NMR $\delta 0.88\left(\mathrm{t}, J=6.6 \mathrm{~Hz}, 3 \mathrm{H}, \mathrm{CH}_{3}\right), 1.24-1.39\left(\mathrm{~m}, 14 \mathrm{H}, 7\right.$ x $\left.\mathrm{CH}_{2}\right), 1.62$ ("quin", $J=7.4$ $\left.\mathrm{Hz}, 2 \mathrm{H}, \mathrm{CH}_{2}\right), 2.10-2.18\left(\mathrm{~m}, 1 \mathrm{H}, \mathrm{H} 2{ }^{\prime}\right), 2.34\left(\mathrm{t}, J=7.7 \mathrm{~Hz}, 2 \mathrm{H}, \mathrm{CH}_{2}\right), 2.42\left(\mathrm{~s}, 3 \mathrm{H}, \mathrm{CH}_{3}\right), 2.49$ (ddd, $J=13.8,6.3,4.0 \mathrm{~Hz}, 1 \mathrm{H}, \mathrm{H} 2 "), 3.00$ (br s, 1H, 3'-OH), 4.17-4.40 (m, 4H, H3',4',5',5"), $6.26\left(\mathrm{t}, J=6.5 \mathrm{~Hz}, 1 \mathrm{H}, \mathrm{H} 1^{\prime}\right), 6.85(\mathrm{~s}, 1 \mathrm{H}, \mathrm{CH}), 7.35(\mathrm{~d}, J=8.1 \mathrm{~Hz}, 2 \mathrm{H}, \mathrm{Ar}), 7.74(\mathrm{~d}, J=8.1$ 
$\mathrm{Hz}, 2 \mathrm{H}, \mathrm{Ar}), 8.33(\mathrm{~s}, 1 \mathrm{H}, \mathrm{H} 6), 8.44(\mathrm{~s}, 1 \mathrm{H}, \mathrm{NH}) ;{ }^{13} \mathrm{C} \mathrm{NMR} \delta$ 14.2, $21.9\left(\mathrm{CH}_{3}\right), 22.0,25.0$, 29.2, 29.4, 29.5, 29.7, 29.8, 32.2, $34.4\left(\mathrm{CH}_{2}\right), 40.8$ (C2'), 63.7 (C5'), $71.6\left(\mathrm{C}^{\prime}\right), 84.7$ (C4'), 85.8 (C1'), 108.2 (C5), 128.0 (Ar), 130.3 (Ar), $134.0(\mathrm{Ar}), 136.0(=\mathrm{CH}), 140.8$ (Ar), 143.0 $\begin{array}{llllllll}(=\mathrm{CCl}), & 146.0 & (\mathrm{C} 6), & 149.3 & (\mathrm{C} 2), & 159.0 & (\mathrm{C} 4), & 174.0 \quad(\mathrm{C}=\mathrm{O}) ;\end{array}$ $\mathrm{C}_{29} \mathrm{H}_{39}{ }^{35} \mathrm{ClN}_{2} \mathrm{NaO}_{8} \mathrm{~S}[\mathrm{M}+\mathrm{Na}]^{+}$633.2013, found 633.2018.

Note: The (E)-3'-O-undecanoyl-5-(1-chloro-2-tosylvinyl)-2'-deoxyuridine (7 mg, 20\%) were also isolated: ${ }^{1} \mathrm{H} \mathrm{NMR}\left(\mathrm{CDCl}_{3}\right) \delta 0.88\left(\mathrm{t}, J=6.6 \mathrm{~Hz}, 3 \mathrm{H}, \mathrm{CH}_{3}\right), 1.22-1.37(\mathrm{~m}, 14 \mathrm{H}, 7 \mathrm{x}$ $\left.\mathrm{CH}_{2}\right), 1.58-1.68\left(\mathrm{~m}, 2 \mathrm{H}, \mathrm{CH}_{2}\right), 2.35\left(\mathrm{t}, J=7.6 \mathrm{~Hz}, 2 \mathrm{H}, \mathrm{CH}_{2}\right), 2.38-2.42(\mathrm{~m}, 1 \mathrm{H}, \mathrm{H} 2$ '), $2.44(\mathrm{~s}$, 3H, CH3-tosyl), 2.5 -2.58 (m, 1H, H2"), 3.89 -3.94 (dd, 1H, H5'), 4.01 -4.06 (dd, 1H, H5"), $4.15-4.19$ (m, 1H, H4'), 5.38 -5.42 (dd, 1H, H3'), $6.34-6.38$ (dd, 1H, H1'), 6.87 (s, 1H, vinyl), 7.34 (d, $J=8.1 \mathrm{~Hz}, 2 \mathrm{H}$-tosyl), 7.70 (d, $J=8.1 \mathrm{~Hz}, 2 \mathrm{H}$-tosyl), 8.34 (s, 1H, H6), 8.44 $(\mathrm{s}, 1 \mathrm{H}, \mathrm{NH})$.

(E)-3',5'-Di-O-undecanoyl-5-(1-chloro-2-tosylvinyl)-2'-deoxyuridine (76). Treatment of (25 mg, $0.056 \mathrm{mmol})$ with undecanoic anhydride $(62 \mathrm{mg}, 0.17 \mathrm{mmol})$ and DMAP $(6.0 \mathrm{mg}$, $0.05 \mathrm{mmol}$ ) in DMF for $6 \mathrm{~h}$ by Procedure G and column chromatography (hexane/EtOAc, 100:0 $\rightarrow$ 80:20) gave $76(32 \mathrm{mg}, 75 \%):{ }^{1} \mathrm{H}$ NMR $\delta 0.84-0.90\left(\mathrm{~m}, 6 \mathrm{H}, 2 \times \mathrm{CH}_{3}\right), 1.20-1.37(\mathrm{~m}$, 28H, $14 \times \mathrm{CH}_{2}$ ), 1.60-1.68 (m, 4H, $2 \times \mathrm{CH}_{2}$ ), 2.35 ("t", $J=8.2 \mathrm{~Hz}, 4 \mathrm{H}, 2 \times \mathrm{CH}_{2}$ ), 2.38-2.42 (m, 1H, H2'), 2.46 (s, 3H, CH CH, 2.57 (ddd, $J=12.8,5.4,2.1 \mathrm{~Hz}, 1 \mathrm{H}, \mathrm{H} 2 "), 4.29-4.32$ (m, 1H, H4'), 4.42 (dd, $J=12.1,2.4 \mathrm{~Hz}, 1 \mathrm{H}, \mathrm{H} 5$ '), 4.50 (dd, $J=12.1,2.3 \mathrm{~Hz}, 1 \mathrm{H}, \mathrm{H} 5 "), 5.23-5.27$ (m, 1H, H3'), 6.35(dd, $J=8.5,5.5 \mathrm{~Hz}, 1 \mathrm{H}, \mathrm{H1}$ '), 6.88 (s, 1H, vinyl), 7.34 (d, $J=8.1 \mathrm{~Hz}, 2 \mathrm{H}, \mathrm{Ar}$ ), $7.70(\mathrm{~d}, J=8.1 \mathrm{~Hz}, 2 \mathrm{H}, \mathrm{Ar}), 7.90(\mathrm{~s}, 1 \mathrm{H}, \mathrm{H} 6), 8.34(\mathrm{~s}, 1 \mathrm{H}, \mathrm{NH}) ;{ }^{13} \mathrm{C} \mathrm{NMR} \delta 14.2,21.8\left(\mathrm{CH}_{3}\right)$, $22.8,24.9,25.0,29.3,29.37,29.43,29.5,29.58,29.63,29.69,29.72,32.0,34.2,34.3\left(\mathrm{CH}_{2}\right)$, 38.2 (C2'), 63.8 (C5'), 74.2 (C3'), 83.3 (C4'), 85.8 (C1'), 109.1 (C5), 128.0 (Ar), 130.2 (Ar), 
134.9 (=CH), 136.9 (Ar), 139.9 (Ar), 141.6 (C6), 145.6 (=CCl), 149.1 (C2), $158.6(\mathrm{C} 4)$, 173.3, $173.4(\mathrm{C}=\mathrm{O})$; HRMS calcd for $\mathrm{C}_{40} \mathrm{H}_{59}{ }^{35} \mathrm{ClN}_{2} \mathrm{NaO}_{9} \mathrm{~S}[\mathrm{M}+\mathrm{Na}]^{+}$801.3527, found 801.3505 .

3',5'-Di- $\boldsymbol{O}$-acetyl-5-(5-heptylfur-2-yl)-2'-deoxyuridine (79). $2^{121}$ (150 mg, $0.34 \mathrm{mmol}$ ) was dissolved in $2 \mathrm{~mL}$ of DMF. 2-Heptylfuran (0.6 mL, $565 \mathrm{mg}, 3.4 \mathrm{mmol}$ ), TBAF (2.3 mL, $2.38 \mathrm{mmol})$, and $\mathrm{Pd}_{2}(\mathrm{dba})_{3}(12 \mathrm{mg}, 0.021 \mathrm{mmol})$ were sequentially added into the solution. The resulting mixtures were stirred at $100{ }^{\circ} \mathrm{C}$ for $1 \mathrm{~h}$. The volátiles were evapórated and column chromatography; hexane/EtOAc, $80: 20 \rightarrow 60: 40$ gave $79(86 \mathrm{mg}, 60 \%):{ }^{1} \mathrm{H}$ NMR $\delta$ $0.87\left(\mathrm{t}, J=7.1 \mathrm{~Hz}, 3 \mathrm{H}, \mathrm{CH}_{3}\right), 1.22-1.37\left(\mathrm{~m}, 8 \mathrm{H}, 4 \times \mathrm{CH}_{2}\right), 1.61\left(\mathrm{q}, J=7.4 \mathrm{~Hz}, 2 \mathrm{H}, \mathrm{CH}_{2}\right), 2.11$ (s, 3H, $\mathrm{CH}_{3}$ ), 2.12 (s, 3H, $\mathrm{CH}_{3}$ ), 2.25 ("ddd", $J=16.6,8.7,2.2 \mathrm{~Hz}, 1 \mathrm{H}, \mathrm{H} 2$ '), 2.50-2.57 (m, 1H, H2"), 2.59 (t, $J=7.5 \mathrm{~Hz}, 2 \mathrm{H}, \mathrm{CH}_{2}$ ), 4.30-4.34 (m, 1H, H4'), 4.38-4.42 (m, 2H, H5',5"), 5.28 ("dt", $J=6.4,1.6 \mathrm{~Hz}, 1 \mathrm{H}, \mathrm{H} 3$ '), 6.05 (d, $J=3.3 \mathrm{~Hz}, 1 \mathrm{H}$, furan), 6.40 (dd, $J=8.6,5.5 \mathrm{~Hz}$, 1H, H1'), 6.98 (d, $J=3.3 \mathrm{~Hz}, 1 \mathrm{H}$, furan), 7.85 (s, 1H, H6), 9.30 (s, 1H, NH); ${ }^{13} \mathrm{C}$ NMR $\delta 14.2$ $\left(\mathrm{CH}_{3}\right), 20.9,21.1(\mathrm{Ac}), 22.8,28.1,28.2,29.2,29.3,31.9\left(\mathrm{CH}_{2}\right), 38.1(\mathrm{C} 2), 61.2\left(\mathrm{C}^{\prime}\right), 74.7$ (C3'), 82.7 (C4'), 85.7 (C1'), 107.4 (furan), 108.2 (C5), 111.0 (furan), 131.3 (C6), 143.8, 149.4 (furan), 156.2 (C2), 159.9 (C4), 170.3, 170.5 (Ac); HRMS calcd for $\mathrm{C}_{24} \mathrm{H}_{32} \mathrm{~N}_{2} \mathrm{NaO}_{8}[\mathrm{M}+\mathrm{Na}]^{+}$ 499.2056, found 499.2078.

5-(5-Heptylfur-2-yl)-2'-deoxyuridine (81). 5-Iodo-2'-deoxyuridine 77 (53 mg, 0.15 mmol) was dissolved in $2 \mathrm{~mL}$ DMF. Then, 2-heptylfuran (0.29 mL, $249 \mathrm{mg}, 1.5 \mathrm{mmol})$, TBAF ( $1 \mathrm{~mL}, 1.05 \mathrm{mmol}), \mathrm{Pd}_{2}(\mathrm{dba})_{3}(10 \mathrm{mg}, 0.017 \mathrm{mmol})$ were sequentially added into the solution. The mixtures were stirred at $100{ }^{\circ} \mathrm{C}$ for $1 \mathrm{~h}$. The volatiles were evaporated and column chromatography (hexane/EtOAc, 20:80) gave 81 (35 mg, 61\%): UV (MeOH) $\lambda_{\max }$ 256, $326 \mathrm{~nm}(\varepsilon 14250,11300), \lambda_{\min } 287 \mathrm{~nm}(\varepsilon 4000) ;{ }^{1} \mathrm{H}$ NMR (DMSO- $\left.d_{6}\right) \delta 0.86$ (t, $J=6.7$ 
$\mathrm{Hz}, 3 \mathrm{H}, \mathrm{CH}_{3}$ ), 1.24-1.31 (m, 8H, 4 x CH 2 ), 1.60 (quin, $J=6.7 \mathrm{~Hz}, 2 \mathrm{H}$, heptyl), 2.17 ("dd", $J=$ 6.6, $\left.4.9 \mathrm{~Hz}, 2 \mathrm{H}, \mathrm{H}^{\prime}, 2 "\right), 2.60$ (t, $\left.J=7.4 \mathrm{~Hz}, 2 \mathrm{H}, \mathrm{CH}_{2}\right), 3.60-3.62\left(\mathrm{~m}, 2 \mathrm{H}, \mathrm{H}^{\prime}, 5 "\right), 3.83$ (q, $J=$ $3.3 \mathrm{~Hz}, 1 \mathrm{H}, \mathrm{H} 4$ '), 4.29 (quin, $\left.J=4.2,1 \mathrm{H}, \mathrm{H} 3^{\prime}\right), 5.05\left(\mathrm{t}, J=5.0 \mathrm{~Hz}, 1 \mathrm{H}, 5^{\prime}-\mathrm{OH}\right.$ ), 5.28 (d, $J=4.1$ Hz, 1H, 3'-OH), 6.11 (d, $J=3.1 \mathrm{~Hz}, 1 \mathrm{H}$, furan), $6.21(\mathrm{t}, J=6.6 \mathrm{~Hz}, 1 \mathrm{H}, \mathrm{H1}), 6.72(\mathrm{~d}, J=3.1$ $\mathrm{Hz}, 1 \mathrm{H}$, furan), 8.27 (s, 1H, H6), $11.58(\mathrm{~s}, 1 \mathrm{H}, \mathrm{NH}) ;{ }^{13} \mathrm{C}$ NMR $\delta$ 14.2, 22.1, 27.0, 28.6, 31.1, 39.4, 60.8, 70.3, 84.5, 87.4, 105.7, 106.8, 108.6, 133.6, 144.5, 149.6, 154.8, 160.0; HRMS calcd for $\mathrm{C}_{20} \mathrm{H}_{29} \mathrm{~N}_{2} \mathrm{O}_{6}[\mathrm{M}+\mathrm{H}]^{+}$393.2020, found 393.2023

5'-O-Undecanoyl-5-(fur-2-yl)-2'-deoxyuridine (82). Treatment of $\mathbf{8 0}^{122}(25 \mathrm{mg}, 0.08$ mmol) with undecanoic anhydride $(34 \mathrm{mg}, 0.096 \mathrm{mmol})$ in the presence of DMAP $(6.0 \mathrm{mg}$, $0.05 \mathrm{mmol}$ ) in DMF for $2 \mathrm{~h}$ by Procedure $\mathrm{G}$ and column chromatography; hexane/EtOAc, 100:0 $\rightarrow$ 70:30) gave $82(18 \mathrm{mg}, 52 \%)$ and $\mathbf{8 3}(5 \mathrm{mg}, 10 \%)$ in addition to unchanged $\mathbf{8 0}$ ( 15\%; TLC). Compound 82 had: ${ }^{1} \mathrm{H}$ NMR $\delta 0.88\left(\mathrm{t}, J=7.1 \mathrm{~Hz}, 3 \mathrm{H}, \mathrm{CH}_{3}\right), 1.22-1.40(\mathrm{~m}$, 14H, 7 x CH CH$_{2}, 1.60$ ("quin", $J=7.3 \mathrm{~Hz}, 2 \mathrm{H}, \mathrm{CH}_{2}$ ), 2.10-2.17 (m, 1H, H2'), 2.35 (t, $J=7.6 \mathrm{~Hz}$, 2H, $\mathrm{CH}_{2}$ ), 2.50 (ddd, $\left.J=13.7,6.3,3.9 \mathrm{~Hz}, 1 \mathrm{H}, \mathrm{H} 2 "\right), 3.05$ (br s, 1H, 3'-OH), 4.15 (q, $J=3.9$, 1H, H4'), 4.25 (dd, $\left.J=12.1,3.3 \mathrm{~Hz}, 1 \mathrm{H}, \mathrm{H} 5^{\prime}\right), 4.36-4.42$ (m, 2H, H3',5"), 6.26 (t, $J=6.3 \mathrm{~Hz}$, 1H, H1'), 6.60 (dd, $J=3.3,1.8 \mathrm{~Hz}, 1 \mathrm{H}$, furan), $7.05(\mathrm{~d}, J=3.5 \mathrm{~Hz}, 1 \mathrm{H}$, furan), 7.38 (d, $J=1.2$ $\mathrm{Hz}, 1 \mathrm{H}$, furan), 8.25 (s, $1 \mathrm{H}, \mathrm{H} 6), 8.38(\mathrm{~s}, 1 \mathrm{H}, \mathrm{NH})$; HRMS calcd for $\mathrm{C}_{24} \mathrm{H}_{34} \mathrm{~N}_{2} \mathrm{NaO}_{7}[\mathrm{M}+\mathrm{Na}]^{+}$ 485.2264; found 485.2271.

Note: 3'-O-Undecanoyl-5-(fur-2-yl)-2'-deoxyuridine $(6.0 \mathrm{mg}, 15 \%)$ was also isolated: ${ }^{1} \mathrm{H}$ $\operatorname{NMR}\left(\mathrm{CDCl}_{3}\right) \delta$ 0.85-0.93 (m, 6H, $\left.2 \times \mathrm{CH}_{3}\right), 1.22-1.37\left(\mathrm{~m}, 24 \mathrm{H}, 12 \times \mathrm{CH}_{2}\right), 1.58-1.68(\mathrm{~m}$, 4H, $2 \times \mathrm{CH}_{2}$ ), 2.35 (t, $J=7.6 \mathrm{~Hz}, 2 \mathrm{H}, \mathrm{CH}_{2-}$ undecanoyl), 2.45 (dt, 1H, H2'), 2.55 (dt, 1H, H2"), 2.64 (t, 2H, $J=7.6 \mathrm{~Hz}, \mathrm{CH}_{2}$ - heptyl), 3.90 - 4.00 (dd, 1H, H5'5"), $4.13-4.18$ (m, 1H, 
H4'), 5.38 -5.42 (dd, 1H, H3'), 6.05 (d, , J = 3.2 Hz, 1H-furan), 6.29 -6.35 (dd, 1H, H1'), 6.90 (d, $J=3.2 \mathrm{~Hz}, 1 \mathrm{H}$-furan), $8.10(\mathrm{~s}, 1 \mathrm{H}, \mathrm{H} 6), 8.44(\mathrm{~s}, 1 \mathrm{H}, \mathrm{NH})$.

3',5'-Di-O-undecanoyl-5-(fur-2-yl)-2'-deoxyuridine (83). Treatment of $\mathbf{8 0}^{122}$ (25 mg, $0.08 \mathrm{mmol})$ with undecanoic anhydride $(84 \mathrm{mg}, 0.24 \mathrm{mmol})$ in the presence of DMAP $(6.0$ $\mathrm{mg}, 0.05 \mathrm{mmol})$ by Procedure G (6 h) gave $83(38.5 \mathrm{mg}, 77 \%):{ }^{1} \mathrm{H}$ NMR $\delta 0.82-0.91(\mathrm{~m}, 6 \mathrm{H}$, $\left.2 \times \mathrm{CH}_{3}\right), 1.20-1.40\left(\mathrm{~m}, 28 \mathrm{H}, 14 \times \mathrm{CH}_{2}\right), 1.60-1.68\left(\mathrm{~m}, 4 \mathrm{H}, 2 \times \mathrm{CH}_{2}\right), 2.24$ (ddd, $J=14.6,8.6$, $6.5 \mathrm{~Hz}, 1 \mathrm{H}, \mathrm{H} 2$ '), 2.33-2.40 (m, 4H, 2 x CH 2$), 2.54$ (ddd, $J=14.1,5.6,1.3 \mathrm{~Hz}, 1 \mathrm{H}, \mathrm{H} 2 "), 4.30$ ("q", $\left.J=2.7 \mathrm{~Hz}, 1 \mathrm{H}, \mathrm{H} 4{ }^{\prime}\right), 4.36\left(\mathrm{dd}, J=12.2,2.8 \mathrm{~Hz}, 1 \mathrm{H}, \mathrm{H} 5^{\prime}\right), 4.45$ (dd, $J=11.8,3.5 \mathrm{~Hz}, 1 \mathrm{H}$, H5"), 5.27 ("dt", $J=6.4,1.6 \mathrm{~Hz}, 1 \mathrm{H}, \mathrm{H} 3$ '), 6.40 (dd, $J=8.8,6.1 \mathrm{~Hz}, 1 \mathrm{H}, \mathrm{H} 1$ '), 6.47 (dd, $J=$ 3.3, 1.8 Hz, 1H, furan), 7.05 (d, $J=3.4 \mathrm{~Hz}, 1 \mathrm{H}$, furan), 7.33 (d, $J=1.6 \mathrm{~Hz}, 1 \mathrm{H}$, furan), 8.00 (s, 1H, H6), 8.95 (s, 1H, NH); ${ }^{13} \mathrm{C}$ NMR $\delta 14.5,23.0,25.1,25.2,29.3,29.4,29.6,29.7,29.9$, 32.3, 34.1, 34.3, 34.5, 39.0 (C2'), 64.0 (C5'), 74.6 (C3'), 83.2 (C4'), 86.0 (C1'), 108.0 (C5), 110.0 (furan), 112.5 (furan), 133.0 (C6), 142.0 (furan), 146.0 (furan), 149.5 (C2), 160.2 (C4), 173.2, $173.4(\mathrm{C}=\mathrm{O})$; HRMS calcd for $\mathrm{C}_{35} \mathrm{H}_{54} \mathrm{~N}_{2} \mathrm{NaO}_{8}[\mathrm{M}+\mathrm{Na}]^{+} 653.3778$, found 653.3778 .

5'-O-Undecanoyl-5-(5-heptylfur-2-yl)-2'-deoxyuridine (84). Treatment of 81 (25 mg, $0.064 \mathrm{mmol})$ with undecanoic anhydride $(27.2 \mathrm{mg}, 0.0768 \mathrm{mmol})$ in the presence of DMAP $(6.0 \mathrm{mg}, 0.05 \mathrm{mmol})$ for $2 \mathrm{~h}$ and column chromatography (hexane/EtOAc, 100:0 $\rightarrow$ 80:20) gave 84(17 mg, 48\%). ${ }^{1} \mathrm{H}$ NMR $\delta$ 0.85-0.90 (m, 6H, $\left.2 \times \mathrm{CH}_{3}\right), 1.28-1.31\left(\mathrm{~m}, 22 \mathrm{H}, 11 \times \mathrm{CH}_{2}\right)$, 1.54-1.64 (m, 4H, $\left.2 \times \mathrm{CH}_{2}\right), 2.13-2.16\left(\mathrm{~m}, 1 \mathrm{H}, \mathrm{H} 2\right.$ '), 2.27-2.32 (m, 2H, $\mathrm{CH}_{2}$ ), 2.46 (ddd, J $=13.9,6.4,4.3 \mathrm{~Hz}, 1 \mathrm{H}, \mathrm{H} 2 "), 2.56\left(\mathrm{t}, J=7.4 \mathrm{~Hz}, 2 \mathrm{H}, \mathrm{CH}_{2}\right), 2.98\left(\mathrm{~s}, 1 \mathrm{H}, 3^{\prime}-\mathrm{OH}\right), 4.19$ (q, $J=$ 3.5, 1H, H4'), $4.28\left(\mathrm{dd}, J=12.3,3.4 \mathrm{~Hz}, 1 \mathrm{H}, \mathrm{H} 5^{\prime}\right), 4.33-4.41\left(\mathrm{~m}, 2 \mathrm{H}, \mathrm{H} 3^{\prime}, 5^{\prime \prime}\right), 6.05$ (d, $J=3.2$ Hz, 1H-furan), 6.28 (t, $J=6.4 \mathrm{~Hz}, 1 \mathrm{H}, \mathrm{H} 1$ '), 6.90 (d, J = 3.2 Hz, 1H-furan), 8.10 (s, 1H, H6), $8.44(\mathrm{~s}, 1 \mathrm{H}, \mathrm{NH}) ;{ }^{13} \mathrm{C} \mathrm{NMR} \delta$ 14.2, $22.9\left(\mathrm{CH}_{3}\right), 24.9,28.1,28.2,29.2,29.2,29.3,29.4,29.5$, 
29.6, 29.7, 31.9, 32.1, 34.2, 34.3, $34.4\left(\mathrm{CH}_{2}\right), 40.7$ (C2'), 63.6 (C5'), 71.8 (C3'), $84.4\left(\mathrm{C}^{\prime}\right)$, 85.5 (C1'), 108.2 (C5), 110.6 (furan), 113.0 (furan), 129.0 (furan), 133.0 (C6), 149 (C2), 156.0 (furan), $159.6(\mathrm{C} 4), 174.0(\mathrm{C}=\mathrm{O})$; HRMS calcd for $\mathrm{C}_{31} \mathrm{H}_{48} \mathrm{~N}_{2} \mathrm{NaO}_{7}[\mathrm{M}+\mathrm{Na}]^{+}$583.3359, found 583.3375.

Note: 3'-O-undecanoyl-5-(heptylfur-2-yl)-2'-deoxyuridine $(6.1 \mathrm{mg}, 17 \%)$ was also isolated: ${ }^{1} \mathrm{H}$ NMR $\left(\mathrm{CDCl}_{3}\right) \delta 0.88\left(\mathrm{t}, J=7.1 \mathrm{~Hz}, 3 \mathrm{H}, \mathrm{CH}_{3}\right), 1.22-1.40\left(\mathrm{~m}, 14 \mathrm{H}, 7 \times \mathrm{CH}_{2}\right), 1.60$ $-1.65\left(\mathrm{~m}, 2 \mathrm{H}, \mathrm{CH}_{2}\right), 2.35\left(\mathrm{t}, J=7.6 \mathrm{~Hz}, 2 \mathrm{H}, \mathrm{CH}_{2}\right), 2.44-2.58(\mathrm{~m}, 2 \mathrm{H}, \mathrm{H} 2$ '), 4.0 (dd, 2H, H5'), 4.15(m, 1H, H4'), 5.40 (dd, 1H, H3'), 6.35 (dd, 1H, H1'), 6.6 (dd, 1H, furan), 7.05 (d, $J=3.5$ $\mathrm{Hz}, 1 \mathrm{H}$, furan), $7.38(\mathrm{~d}, J=1.2 \mathrm{~Hz}, 1 \mathrm{H}$, furan), $7.34(\mathrm{~d}, J=8.1 \mathrm{~Hz}, 2 \mathrm{H}$-tosyl), 8.25 (s, 1H, H6), 8.38 (s, 1H, NH).

3',5'-Di- $O$-undecanoyl-5-(5-heptylfur-2-yl)-2'-deoxyuridine (85). Treatment of 81 (25 $\mathrm{mg}, 0.064 \mathrm{mmol})$ with undecanoic anhydride $(65 \mathrm{mg}, 0.19 \mathrm{mmol})$ in the presence of DMAP ( $6.0 \mathrm{mg}, 0.05 \mathrm{mmol}$ ) for $6 \mathrm{~h}$ and column chromatography (hexane/EtOAc, 100:0 $\rightarrow$ 80:20) gave 85 (36 mg, 80\%). ${ }^{1} \mathrm{H}$ NMR $\delta$ 0.83-0.92 (m, 9H, $\left.3 \times \mathrm{CH}_{3}\right), 1.22-1.38\left(\mathrm{~m}, 36 \mathrm{H}, 18 \times \mathrm{CH}_{2}\right)$, 1.55-1.70 (m, 6H, $\left.3 \times \mathrm{CH}_{2}\right), 2.25$ (ddd, $J=14.7,8.5,6.6 \mathrm{~Hz}, 1 \mathrm{H}, \mathrm{H} 2$ '), 2.30-2.40 (m, 4H, 2 x $\left.\mathrm{CH}_{2}\right), 2.53-2.57(\mathrm{~m}, 1 \mathrm{H}, \mathrm{H} 2 "), 2.60\left(\mathrm{t}, J=7.6 \mathrm{~Hz}, 2 \mathrm{H}, \mathrm{CH}_{2}\right), 4.31(\mathrm{q}, J=3.01 \mathrm{H}, \mathrm{H} 4$ '), 4.38 (dd, $J=12.2,2.8 \mathrm{~Hz}, 1 \mathrm{H}, \mathrm{H} 5$ '), 4.42 (dd, $J=11.3,3.8 \mathrm{~Hz}, 1 \mathrm{H}, \mathrm{H} 5 "), 5.26$ ("dt", $J=6.8,1.6$ $\left.\mathrm{Hz}, 1 \mathrm{H}, \mathrm{H} 3{ }^{\prime}\right), 6.05\left(\mathrm{~d}, J=3.2 \mathrm{~Hz}, 1 \mathrm{H}\right.$, furan), $\left.6.37(\mathrm{dd}, J=8.8,6.1 \mathrm{~Hz}, 1 \mathrm{H}, \mathrm{H1})^{\prime}\right), 6.95$ (d, $J=$ $3.3 \mathrm{~Hz}, 1 \mathrm{H}$, furan), 7.88 (s, 1H, H6), $9.00\left(\mathrm{~s}, 1 \mathrm{H}, \mathrm{NH}\right.$ ); HRMS calcd for $\mathrm{C}_{42} \mathrm{H}_{68} \mathrm{~N}_{2} \mathrm{NaO}_{8}$ $[\mathrm{M}+\mathrm{Na}]^{+}$751.4873, found 751.4851 . 


\subsection{Incorporation of 5-modified nucleotides into DNA}

\section{Materials of enzymatic reactions}

All DNA oligonucleotides were synthesized following the Integrated DNA Technologies (Coralville, IA). The radionucleotides $\left.\gamma-{ }^{32} \mathrm{P}\right]$ ATP $(6000 \mathrm{mCi} / \mathrm{mmol})$ was purchased from MP biomedicals Inc. (Santa Ana, CA) while T4 polynucleotide kinase and deoxynucleoside 5'triphosphates (dNTPs) were purchased from Thermo Scientific (Pittsburgh, PA). Micro BioSpin TM 6 Columns were purchased from Bio-Rad (Hercules, CA). All other chemicals were purchased from Thermo Scientific (Pittsburgh, PA) and Sigma-Aldrich (St. Louis, MO). Purified DNA polymerase $\beta$ (pol $\beta$ ) were purified following the procedures described previously. ${ }^{123,124}$ Klenow fragment was bought from New England Biolabs (Ipswitch, MA).

\section{Oligonucleotide substrates}

Substrates with an upstream primer annealed to the template strand were designated as open template substrates. The substrates were made by annealing upstream primer (31nt) with the template strand $(71 \mathrm{nt})$ at a molar ratio of 1:3. The substrate containing one-nucleotide gap were made by annealing an upstream primer and downstream primer with the template strand at the molar ratio of 1:3:3. The open template and one-nucleotide gap substrates were employed to mimic the intermediates formed during DNA replication.

\section{Enzymatic activity assay}

Nucleotides incorporation by DNA polymerases were performed by incubating different concentrations of pol $\beta$ or Klenow fragment with $25 \mathrm{nM}^{32} \mathrm{P}$ labeled substrates at $37^{\circ} \mathrm{C}$ for 15 min. The enzymatic reactions were assembled in the presence of 5-( $\beta$-chlorovinyl)sulfone of $\mathrm{dU}(50 \mu \mathrm{M})$ or $5-(\beta$-keto)sulfone of $\mathrm{dU}(50 \mu \mathrm{M})$ alone or in the presence of $50 \mu \mathrm{M} 5-(\beta-$ chlorovinyl)sulfone of dU or $50 \mu \mathrm{M} 5$-( $\beta$-keto)sulfone of dU along with $50 \mu \mathrm{M}$ dATP, $50 \mu \mathrm{M}$ 
$\mathrm{dCTP}$ and $50 \mu \mathrm{M}$ dGTP. This allows to examine if 5-( $\beta$-chlorovinyl)sulfone of $\mathrm{dU}$ or 5-( $\beta$ keto)sulfone of dU residue can be directly incorporated into a double-strand DNA during DNA leading and lagging strand maturation. DNA synthesis was separated in a $15 \%$ urea denaturing polyacrylamide gel were detected by Pharos FX Plus PhosphorImager (Bio-Rad Laboratory, CA).

\subsection{Cytotoxic evaluation}

\section{Proliferation Assays}

Human cervical carcinoma (HeLa) cells were seeded in 96-well plates at 15,000 cells/well in the presence of 5-fold dilutions of the compounds. After 4 days of incubation, the cells were trypsinized and counted by means of a Coulter counter (Analis, Belgium). Suspension cells (Mouse leukemia L1210 and human lymphoid CEM cells) were seeded in 96-well plates at 60,000 cells/well in the presence of the compounds. L1210 and CEM cells were allowed to proliferate for $48 \mathrm{~h}$ or $96 \mathrm{~h}$, respectively and then counted. The $50 \%$ inhibitory concentration $\left(\mathrm{IC}_{50}\right)$ was defined as the compound concentration required to reduce cell proliferation by $50 \%$.

\section{Antiviral Assays}

The compounds were evaluated against the following viruses: herpes simplex virus type 1 (HSV-1) strain KOS, thymidine kinase-deficient (TK') HSV-1 KOS strain resistant to ACV $\left(A C V^{1}\right)$, herpes simplex virus type $2(\mathrm{HSV}-2)$ strain $\mathrm{G}$, varicella-zoster virus (VZV) strain Oka, TK ${ }^{-}$VZV strain 07-1, human cytomegalovirus (HCMV) strains AD-169 and Davis, vaccinia virus Lederle strain, respiratory syncytial virus (RSV) strain Long, vesicular stomatitis virus (VSV), Coxsackie B4, parainfluenza 3, influenza virus A (subtypes H1N1, H3N2), influenza virus B, Sindbis, reovirus-1, Punta Toro, human immunodeficiency virus 
type 1 strain IIIB and human immunodeficiency virus type 2 strain ROD. The antiviral, other than anti-HIV, assays were based on inhibition of virus-induced cytopathicity or plaque formation in human embryonic lung (HEL) fibroblasts, African green monkey cells (Vero), human epithelial cells (HeLa) or Madin-Darby canine kidney cells (MDCK). Confluent cell cultures in microtiter 96-well plates were inoculated with 100 CCID50 of virus (1 CCID50 being the virus dose to infect $50 \%$ of the cell cultures) or with 20 or 100 plaque forming units (PFU) (VZV or HCMV) in the presence of varying concentrations of the test compounds. Viral cytopathicity or plaque formation was recorded as soon as it reached completion in the control virus-infected cell cultures that were not treated with the test compounds. Antiviral activity was expressed as the $\mathrm{EC}_{50}$ or compound concentration required to reduce virusinduced cytopathogenicity or viral plaque formation by $50 \%$. Cytotoxicity of the test compounds was expressed as the minimum cytotoxic concentration (MCC) or the compound concentration that caused a microscopically detectable alteration of cell morphology 


\section{CONCLUSION}

I have successfully synthesized 5-(1-chloro/bromo-2-tosylvinyl)pyrimidine nucleosides from their corresponding 5-ethynyl analogues via transition metal catalyzed halosulfonylation reaction with moderate to excellent yield (45-90\%). The 5-(1-iodo-2-tosylvinyl)pyrimidine nucleosides analogues were obtained via halosulfonylation reaction by reaction of 5-ethynyl pyrimidine nucleoside analogue with sodium salt of $p$-toluenesulfinic acid and $\mathrm{N}$ iodosuccinamide in moderate yield (42-50\%). The physical, chemical, and biological properties of these novel 5-(1-halo-2-tosylvinyl)pyrimidine nucleosides analogues were also explored. It was discovered that unlike the unsubsituted vinyl sulfone, the ( $\beta$-halo)vinyl sulfones underwent addition-elimination reaction efficiently with varieties of nucleophiles such as amines, thiols etc. Although the ( $\beta$-halo)vinyl sulfones substrates possesses exclusively $E$ stereochemistry at the vinylic position, their addition-elimination products possess either $E$ or $Z$ stereochemistry which was found to be dependent on the type of nucleophiles substitute the halogen atom at the $\beta$-position. If the halogen atom is substituted by the thiolate nucleophile, the addition-elimination reaction occurs with retention of configuration to give exclusively $E$ stereochemistry. If the same halogen atom of the vinyl sulfone analogue is replaced by amino nucleophile in the analogous reaction the stereochemistry of resulting aminovinylsulfones is $Z$ which means that reaction occurs with the inversion of configuration. From the kinetics data it was determined that the rate of reaction follows the descending order as $\mathrm{I} \geq \mathrm{Br}>\mathrm{Cl}$. That means the rate of additionelimination reaction of novel ( $\beta$-halo)vinyl sulfone analogues is dependent on the halogen 
atoms attached at the $\beta$-position. The vinylic proton exchange with deuterium during the addition-elimination reaction was investigated by carrying the reaction in different deuterated solvents such as DMSO- $d_{6}, \mathrm{D}_{2} \mathrm{O}$, or $\mathrm{MeOH}-d_{4}$. The cysteine and tripeptide L-glutathione were incorporated at the $\beta$-position of the uracil nucleoside analogues via conjugated additionelimination reaction. Antiproliferative and antivirul properties of the ( $\beta$-halo)vinyl sulfone analogues were examined and it was found that acetyl protected ( $\beta$-chloro)vinyl sulfone analogue inhibited the growth of the L1210, CEM, and HeLa cancer cells in the lower $\mu \mathrm{M}$ range. The lipophilic undecanoyl groups were incorporated at the sugar moiety via esterification reaction to enhance the cell permeability of these analogues but unfortunately they did not show improved cytostatic activity.

Novel ( $\beta$-keto)sulfone analogues of 5-modified pyrimidine nucleoside have been synthesized and their reactivity at the acidic $\alpha$-carbon were explored. So, 5-( $\beta$ chloro)vinylsulfones were efficiently converted into the corresponding 5-( $\beta$-keto)sulfone analogues via a one pot synthetic procedure. Thus, $(E)-(\beta$-chloro)vinylsulfone analogues were converted into $(Z)-(\beta$-amino)vinylsulfone by treatment with methanolic ammonia. Subsequent acid hydrolysis efficiently converted the intermediary amino sulfone into $\beta$-keto sulfone analogues with good yield (60-70\%). Since the proton at $\alpha$-carbon of $\beta$-keto sulfone is acidic, novel chemistry at the $\alpha$-carbon of $\beta$-keto sulfones were investigated. The reactivity at the $\alpha$ carbon of $\beta$-keto sulfone analogues with different electrophiles and nucleophiles were elaborately explored to find a suitable way to incorporate amino acid residues at the $\alpha$-carbon which would verify the feasibility of the bioconjugation of the 5-( $\beta$-keto)sulfone-modified DNA with proteins. Different electrophiles derived from benzyl, methyl, or allyl halides were efficiently incorporated at the $\alpha$-carbon of $\beta$-keto sulfone analogues. In addition, it was 
demonstrated that in two step protocols the $\alpha$-carbon of $\beta$-keto sulfones can be also substituted by nucleophile. Thus, treatment of 5 -( $\beta$-keto)sulfone-modified 2'-deoxyuridine with iodinemonochloride afforded the product with the $\alpha$-carbon substituted by iodo group. Subsequently, this iodo group served as a good leaving group and was displaced by the thiolate in the presence of triethyl amine. Such approach might be extended to incorporate amino acid possessing active nucleophilic groups at the $\alpha$-carbon of the $\beta$-keto sulfones.

The silyl protected 8-(1-iodo-2-tosylvinyl)-2'-deoxyadenosine was also efficiently synthesized by the iodine mediated halosulfonylation of the corresponding 8-alkynyl substrates with the yield of $48 \%$. The success of this reaction was encouraging to extend this halosulfonylation reaction in future into other purine nucleoside systems.

The 5-( $\beta$-chloro)vinylsulfone- or 5-( $\beta$-keto)sulfone modified 2'-deoxyuridine were efficiently converted to the 5'-triphosphates by applying Yoshikawa method followed by treatment with ammonium pyrophosphate in the presence of tributylamine. These nucleotides were successfully inserted into the DNA by polymerase-catalyzed reactions with either human DNA repaired polymerase (pol $\beta$ ) or bacterial polymerase (pol I). The ( $\beta$-chloro)vinyl sulone analogue was efficiently incorporated both into the open template that leads the DNA synthesis and one nucleotide gap template that lags the DNA synthesis via bacterial polymerase (Pol I) catalyzed reaction. However, the human DNA polymerase (pol $\beta$ ) catalyzed process was successful to incorporate the chlorovinyl analogue into the one nucleotide gap template only. The ( $\beta$-keto) sulfone analogue was efficiently inserted into DNA open template and one nucleotide gap template either by human DNA repaired polymerase (pol $\beta$ ) or bacterial polymerase (pol I). 
The 5-( $\beta$-chloro)vinyl and/or 5-( $\beta$-keto) sulfones might be bioconjugated with the proteins which are involved in DNA replication process. Specifically it would be interested to examine whether the ( $\beta$-chloro)vinyl sulfone modified DNA might bioconjugate with thiol residues of transcription factors such as c-Myc protein and thus uncover the mystery of critical biological functions related to DNA-c-Myc protein interactions. 


\section{REFERENCES}

(1) Cano-Soldado, P.; Pastor-Anglada, M. Med. Res. Rev. 2012, 32, 428-457.

(2) Minuesa, G.; Huber-Ruano, I.; Pastor-Anglada, M.; Koepsell, H.; Clotet, B.; Martinez-Picado, J. Pharmacol. Ther. 2011, 132, 268-279.

(3) Richman, D. D. Nature 2001, 410, 995-1001.

(4) Leyssen, P.; De Clercq, E.; Neyts, J. Antiviral Res. 2008, 78, 9-25.

(5) Broder, C. C. Curr. Opin. Virol. 2012, 2, 176-187.

(6) Vignuzzi, M.; Stone, J. K.; Andino, R. Virus Res. 2005, 107, 173-181.

(7) Ewald, B.; Sampath, D.; Plunkett, W. Oncogene 0000, 27, 6522-6537.

(8) McGinn, C. J.; Shewach, D. S.; Lawrence, T. S. J. Natl Cancer Inst. 1996, $88,1193-1203$.

(9) Chhikara, B. S.; Parang, K. Expert Opin. Drug Deliv. 2010, 7, 1399-1414.

(10) Sahasranaman, S.; Howard, D.; Roy, S. Eur. J. Pharmacol. 2008, 64, 753-767.

(11) Jain, A.; Kwong, L. N.; Javle, M. Curr. Treat. Options Oncol. 2016, 17, 58.

(12) Montalban-Bravo, G.; Garcia-Manero, G. Leukemia 2015, 29, 760-769.

(13) Gandhi, V.; Ayres, M.; Halgren, R. G.; Krett, N. L.; Newman, R. A.; Rosen, S. T. Cancer Res. 2001, 61, 5474-5479.

(14) Stellrecht, C. M.; Ayres, M.; Arya, R.; Gandhi, V. Breast Cancer Res. Treat. 2010, 121, 355-364.

(15) Krett, N. L.; Davies, K. M.; Ayres, M.; Ma, C.; Nabhan, C.; Gandhi, V.; Rosen, S. T. Mol. Cancer Ther. 2004, 3, 1411-1420.

(16) Parker, W. B. Chem. Rev. 2009, 109, 2880-2893.

(17) Clark, J. L.; Hollecker, L.; Mason, J. C.; Stuyver, L. J.; Tharnish, P. M.; Lostia, S.; McBrayer, T. R.; Schinazi, R. F.; Watanabe, K. A.; Otto, M. J.; Furman, P. A.; Stec, W. J.; Patterson, S. E.; Pankiewicz, K. W. J. Med. Chem. 2005, 48, 5504-5508.

(18) Wedemeyer, H.; Forns, X.; Hézode, C.; Lee, S. S.; Scalori, A.; Voulgari, A.; Le Pogam, S.; Nájera, I.; Thommes, J. A. PLoS One 2016, 11, e0145409. 
(19) Le Pogam, S.; Seshaadri, A.; Ewing, A.; Kang, H.; Kosaka, A.; Yan, J.-M.; Berrey, M.; Symonds, B.; De La Rosa, A.; Cammack, N.; Nájera, I. J. Infect. Dis. 2010, 202, 1510-1519.

(20) Bethell, R. C.; Lie, Y. S.; Parkin, N. T. Antivir. Chem. Chemother. 2005, 16, 295-302.

(21) Asahchop, E. L.; Wainberg, M. A.; Sloan, R. D.; Tremblay, C. L. J. Antimicrob. Chemother. 2012, 56, 5000-5008.

(22) Yang, G.; Paintsil, E.; Dutschman, G. E.; Grill, S. P.; Wang, C.-J.; Wang, J.; Tanaka, H.; Hamasaki, T.; Baba, M.; Cheng, Y.-C. Antimicrob. Agents Chemother. 2009, 53, 4640-4646.

(23) Wang, X.; Tanaka, H.; Baba, M.; Cheng, Y.-c. Antimicrob. Agents Chemother. 2009, 53, 3317-3324.

(24) Kern, E. R.; Bidanset, D. J.; Hartline, C. B.; Yan, Z.; Zemlicka, J.; Quenelle, D. C. Antimicrob. Agents Chemother. 2004, 48, 4745-4753.

(25) Chou, S.; Komazin-Meredith, G.; Williams, J. D.; Bowlin, T. L. Antimicrob. Agents Chemother. 2014, 58, 1809-1812.

(26) Berkhout, B.; Eggink, D. Expert Rev. Anti Infect. Ther. 2011, 9, 161-163.

(27) Jordheim, L. P.; Durantel, D.; Zoulim, F.; Dumontet, C. Nat. Rev. Drug Discov. 2013, 12, 447-464.

(28) Schmidt, M. J.; Summerer, D. Angew. Chem. Int. Ed. 2013, 52, 4690-4693.

(29) Zatsepin, T. S.; Stetsenko, D. A.; Gait, M. J.; Oretskaya, T. S. Bioconjugate Chem. 2005, 16, 471-489.

(30) Lönnberg, H. Bioconjugate Chem. 2009, 20, 1065-1094.

(31) Aaronson, J. G.; Klein, L. J.; Momose, A. A.; O’Brien, A. M.; Shaw, A. W.; Tucker, T. J.; Yuan, Y.; Tellers, D. M. Bioconjugate Chem. 2011, 22, 17231728.

(32) Weisbrod, S. H.; Marx, A. Chem. Commun. 2007, 1828-1830.

(33) Schoch, J.; Wiessler, M.; Jäschke, A. J. Am. Chem. Soc. 2010, 132, 8846-8847.

(34) Raindlová, V.; Pohl, R.; Šanda, M.; Hocek, M. Angew. Chem. Int. Ed. 2010, 49, 1064-1066.

(35) Raindlová, V.; Pohl, R.; Hocek, M. Chem. Eur. J. 2012, 18, 4080-4087. 
(36) Dadová, J.; Orság, P.; Pohl, R.; Brázdová, M.; Fojta, M.; Hocek, M. Angew. Chem. Int. Ed. 2013, 52, 10515-10518.

(37) Boukouvalas, J.; Loach, R. P. J. Org. Chem. 2008, 73, 8109-8112.

(38) Urones, B.; Arrayás, R. G.; Carretero, J. C. Org. Lett. 2013, 15, 1120-1123.

(39) Huang, Z.; Kaur, J.; Bhardwaj, A.; Alsaleh, N.; Reisz, J. A.; DuMond, J. F.; King, S. B.; Seubert, J. M.; Zhang, Y.; Knaus, E. E. J. Med. Chem. 2012, 55, 10262-10271.

(40) Dutta, B.; Gilboa, N.; Marek, I. J. Am. Chem. Soc. 2010, 132, 5588-5589.

(41) Zeng, X.; Ilies, L.; Nakamura, E. Org. Lett. 2012, 14, 954-956.

(42) Yang, F.-L.; Tian, S.-K. Tetrahedron Lett. 2017, 58, 487-504.

(43) Li, X.; Shi, X.; Fang, M.; Xu, X. J. Org. Chem 2013, 78, 9499-9504.

(44) Li, X.; Xu, X.; Shi, X. Tetrahedron Lett. 2013, 54, 3071-3074.

(45) Sawangphon, T.; Katrun, P.; Chaisiwamongkhol, K.; Pohmakotr, M.; Reutrakul, V.; Jaipetch, T.; Soorukram, D.; Kuhakarn, C. Synth. Commun. 2013, 43, 1692-1707.

(46) Gao, Y.; Wu, W.; Huang, Y.; Huang, K.; Jiang, H. Org. Chem. Front. 2014, 1, 361-364.

(47) Bi, W.; Ren, C.; Jia, L.; Xia, X.; Chen, X.; Chen, X.; Zhao, Y. Phosphorus Sulfur Silicon Relat. Elem. 2017, 192, 391-396.

(48) Meadows, D. C.; Sanchez, T.; Neamati, N.; North, T. W.; Gervay-Hague, J. Bioorg. Med. Chem. 2007, 15, 1127-1137.

(49) Mendieta, L.; Pico, A.; Tarrago, T.; Teixido, M.; Castillo, M.; Rafecas, L.; Moyano, A.; Giralt, E. ChemMedChem 2010, 5, 1556-1567.

(50) Palmer, J. T.; Rasnick, D.; Klaus, J. L.; Bromme, D. J. Med. Chem. 1995, 38, 3193-3196.

(51) Markitanov, Y. M.; Timoshenko, V. M.; Shermolovich, Y. G. J. Sulfur Chem. 2014, 35, 188-236.

(52) Katritzky, A. R.; Abdel-Fattah, A. A. A.; Wang, M. J. Org. Chem 2003, 68, 1443-1446. 
(53) Lu, Q.; Zhang, J.; Zhao, G.; Qi, Y.; Wang, H.; Lei, A. J. Am. Chem. Soc. 2013, $135,11481-11484$.

(54) Yoshimatsu, M.; Oh-Ishi, K.; Tanabe, G.; Muraoka, O. J. Chem. Soc., Perkin Trans. 1 2002, 1413-1416.

(55) Kreis, M.; Nieger, M.; Bräse, S. J. Organomet. Chem. 2006, 691, 2171-2181.

(56) Bera, S.; Pathak, T. Synlett 2004, 2004, 2147-2150.

(57) Samakkanad, N.; Katrun, P.; Techajaroonjit, T.; Hlekhlai, S.; Pohmakotr, M.; Reutrakul, V.; Jaipetch, T.; Soorukram, D.; Kuhakarn, C. Synthesis 2012, 44, 1693-1699.

(58) Lai, C.; Xi, C.; Jiang, Y.; Hua, R. Tetrahedron Lett. 2005, 46, 513-515.

(59) Sreedhar, B.; Rawat, V. S. Synlett 2012, 2012, 413-417.

(60) Kada, R.; Knoppová, V.; Jurášek, A.; Kováč, J. Tetrahedron 1976, 32, 14111414.

(61) Li, Q.-S.; Li, C.-Y.; Lu, X.; Zhang, H.; Zhu, H.-L. Eur. J. Med. Chem. 2012, 50, 288-295.

(62) Patil, N. T.; Kadota, I.; Shibuya, A.; Gyoung, Y. S.; Yamamoto, Y. Adv. Synth. Catal. 2004, 346, 800-804.

(63) Patil, N. T.; Pahadi, N. K.; Yamamoto, Y. Synthesis 2004, 2004, 2186-2190.

(64) Patil, N. T.; Yamamoto, Y. Tetrahedron Lett. 2004, 45, 3101-3103.

(65) Manabe, K.; Kobayashi, S. Org. Lett. 2003, 5, 3241-3244.

(66) Kashin, A. N.; Mitin, A. V.; Beletskaya, I. P.; Wife, R. Tetrahedron Lett. 2002, $43,2539-2542$.

(67) Michael, J. P.; de Koning, C. B.; Malefetse, T. J.; Yillah, I. Org. Biomol. Chem. 2004, 2, 3510-3517.

(68) Fesenko, A. A.; Shutalev, A. D. Tetrahedron 2010, 66, 7219-7226.

(69) Hanessian, S.; Johnstone, S. J. Org. Chem 1999, 64, 5896-5903.

(70) Flynn, C. J.; Elcoate, C. J.; Lawrence, S. E.; Maguire, A. R. J. Am. Chem. Soc. 2010, 132, 1184-1185.

(71) Wurz, R. P.; Lin, W.; Charette, A. B. Tetrahedron Lett. 2003, 44, 8845-8848. 
(72) Chiara, J. L.; Suárez, J. R. Adv. Synth. Catal. 2011, 353, 575-579.

(73) Pang, W.; Zhu, S.; Xing, C.; Luo, N.; Jiang, H.; Zhu, S. J. Fluorine Chem. 2008, 129, 343-348.

(74) Muthyala, M. K.; Choudhary, S.; Kumar, A. J. Org. Chem 2012, 77, 87878791.

(75) Suryakiran, N.; Prabhakar, P.; Srikanth Reddy, T.; Chinni Mahesh, K.; Rajesh, K.; Venkateswarlu, Y. Tetrahedron Lett. 2007, 48, 877-881.

(76) Suryakiran, N.; Srikanth Reddy, T.; Suresh, V.; Lakshman, M.; Venkateswarlu, Y. Tetrahedron Lett. 2006, 47, 4319-4323.

(77) Suryakiran, N.; Srikanth Reddy, T.; Venkateswarlu, Y. J. Sulfur Chem. 2007, $28,471-476$.

(78) Kumar, D.; Sundaree, M. S.; Patel, G.; Rao, V. S.; Varma, R. S. Tetrahedron Lett. 2006, 47, 8239-8241.

(79) Du, Y.; Tian, F.; Han, L.; Zhu, N. Phosphorus, Sulfur Silicon Relat. Elem. 2012, 187, 1011-1016.

(80) Plażuk, D.; Rybarczyk-Pirek, A.; Zakrzewski, J. J. Organomet. Chem. 2004, 689, 1165-1171.

(81) Xiang, J.; Ipek, M.; Suri, V.; Tam, M.; Xing, Y.; Huang, N.; Zhang, Y.; Tobin, J.; Mansour, T. S.; McKew, J. Bioorg. Med. Chem. 2007, 15, 4396-4405.

(82) Cho, B. T.; Kim, D. J. Tetrahedron: Asymmetry 2001, 12, 2043-2047.

(83) Pokhodylo, N. T.; Matiychuk, V. S.; Obushak, M. D. Synthesis 2009, 2009, 2321-2323.

(84) Saraiva, M. T.; Costa, G. P.; Seus, N.; Schumacher, R. F.; Perin, G.; Paixão, M. W.; Luque, R.; Alves, D. Org. Lett. 2015, 17, 6206-6209.

(85) Xiang, J.; Ipek, M.; Suri, V.; Tam, M.; Xing, Y.; Huang, N.; Zhang, Y.; Tobin, J.; Mansour, T. S.; McKew, J. Bioorg. Med. Chem. 2007, 15, 4396-4405.

(86) Curti, C.; Laget, M.; Carle, A. O.; Gellis, A.; Vanelle, P. Eur. J. Med. Chem. 2007, 42, 880-884.

(87) Wolf, W. M. J. Mol. Struct. 1999, 474, 113-124.

(88) Malhotra, B.; Gandelman, K.; Sachse, R.; Wood, N.; Michel, M. C. Curr. Med. Chem. 2009, 16, 4481-4489. 
(89) Tsui, G. C.; Glenadel, Q.; Lau, C.; Lautens, M. Org. Lett. 2011, 13, 208-211.

(90) Liang, Y.; Suzol, S. H.; Wen, Z.; Artiles, A. G.; Mathivathanan, L.; Raptis, R. G.; Wnuk, S. F. Org. Lett. 2016, 18, 1418-1421.

(91) Liang, Y.; Gloudeman, J.; Wnuk, S. F. J. Org. Chem. 2014, 79, 4094-4103.

(92) Testa, B. Biochem. Pharmacol. 2004, 68, 2097-2106.

(93) Beaumont, K.; Webster, R.; Gardner, I.; Dack, K. Curr. Drug. Metab 2003, 4, 461-485.

(94) Stella, V. J.; Charman, W. N. A.; Naringrekar, V. H. Drugs 1985, 29, 455-473.

(95) Stella, V. J. Expert Opin. Ther. Pat.

2004, 14, 277-280.

(96) Rautio, J.; Kumpulainen, H.; Heimbach, T.; Oliyai, R.; Oh, D.; Jarvinen, T.; Savolainen, J. Nat Rev Drug Discov 2008, 7, 255-270.

(97) Majumdar, S.; Sloan, K. B. Bioorg. Med. Chem. Lett. 2006, 16, 3590-3594.

(98) Peyrottes, S.; Egron, D.; Lefebvre, I.; Gosselin, G.; Imbach, J. L.; Perigaud, C. Mini Rev. Med. Chem. 2004, 4, 395-408.

(99) Kingham, P. Curr. Opin. Investig. Drugs 2000, 1, 90-96.

(100) Rouleau, A.; Garbarg, M.; Ligneau, X.; Mantion, C.; Lavie, P.; Advenier, C.; Lecomte, J. M.; Krause, M.; Stark, H.; Schunack, W.; Schwartz, J. C. J. Pharmacol. Exp. Ther. 1997, 281, 1085-1094.

(101) Simplicio, A. L.; Clancy, J. M.; Gilmer, J. F. Int. J. Pharm. 2007, 336, 208214.

(102) von der Maase, H.; Hansen, S. W.; Roberts, J. T.; Dogliotti, L.; Oliver, T.; Moore, M. J.; Bodrogi, I.; Albers, P.; Knuth, A.; Lippert, C. M.; Kerbrat, P.; Sanchez Rovira, P.; Wersall, P.; Cleall, S. P.; Roychowdhury, D. F.; Tomlin, I.; Visseren-Grul, C. M.; Conte, P. F. J. Clin. Oncol. 2000, 18, 3068-3077.

(103) Shipley, L. A.; Brown, T. J.; Cornpropst, J. D.; Hamilton, M.; Daniels, W. D.; Culp, H. W. Drug Metab. Dispos. 1992, 20, 849-855.

(104) Gollnest, T.; de Oliveira, T. D.; Schols, D.; Balzarini, J.; Meier, C. Nat. Commun. 2015, 6, 8716 . 
(105) Francia, G.; Shaked, Y.; Hashimoto, K.; Sun, J.; Yin, M.; Cesta, C.; Xu, P.; Man, S.; Hackl, C.; Stewart, J.; Uhlik, M.; Dantzig, A. H.; Foster, F. S.; Kerbel, R. S. Mol. Cancer Ther. 2012, 11, 680-689.

(106) Bender, D. M.; Bao, J.; Dantzig, A. H.; Diseroad, W. D.; Law, K. L.; Magnus, N. A.; Peterson, J. A.; Perkins, E. J.; Pu, Y. J.; Reutzel-Edens, S. M.; Remick, D. M.; Starling, J. J.; Stephenson, G. A.; Vaid, R. K.; Zhang, D.; McCarthy, J. R. J. Med. Chem. 2009, 52, 6958-6961.

(107) Bergman, A. M.; Adema, A. D.; Balzarini, J.; Bruheim, S.; Fichtner, I.; Noordhuis, P.; Fodstad, Ø.; Myhren, F.; Sandvold, M. L.; Hendriks, H. R.; Peters, G. J. Inves New Drugs 2011, 29, 456-466.

(108) Sandvold, M. L.; Galmarini, C.; Myhren, F.; Peters, G. Nucleos. Nucleot. Nucl. 2010, 29, 386-393.

(109) Caudle, K. E.; Thorn, C. F.; Klein, T. E.; Swen, J. J.; McLeod, H. L.; Diasio, R. B.; Schwab, M. Clin. Pharmacol. Ther. 2013, 94, 640-645.

(110) Ferraboschi, P.; Samuele Ciceri, S.; Grisenti, P. Org. Prep. Proc. Int. 2017, 49, 69-154.

(111) Gentile, I.; Coppola, N.; Buonomo, A. R.; Zappulo, E.; Borgia, G. Expert Opin. Investig. Drugs 2014, 23, 1211-1223.

(112) Robins, M. J.; Manfredini, S.; Wood, S. G.; Wanklin, R. J.; Rennie, B. A.; Sacks, S. L. J. Med. Chem. 1991, 34, 2275-2280.

(113) Bobek, M.; Kavai, I.; Sharma, R. A.; Grill, S.; Dutschman, G.; Cheng, Y. C. J. Med. Chem. 1987, 30, 2154-2157.

(114) Gearhart, J.; Pashos, E. E.; Prasad, M. K. The New England journal of medicine 2007, 357, 1469-1472.

(115) Wei, W.; Li, J.; Yang, D.; Wen, J.; Jiao, Y.; You, J.; Wang, H. Org. Biomol. Chem. 2014, 12, 1861-1864.

(116) Dadová, J.; Orság, P.; Pohl, R.; Brázdová, M.; Fojta, M.; Hocek, M. Angew. Chem. Int. Ed. 2013, 52, 10515-10518.

(117) Reddy, M. R.; Shibata, N.; Kondo, Y.; Nakamura, S.; Toru, T. Angew. Chem. Int. Ed. 2006, 118, 8343-8346.

(118) Manfredini, S.; Baraldi, P. G.; Bazzanini, R.; Marangoni, M.; Simoni, D.; Balzarini, J.; De Clercq, E. J. Med. Chem. 1995, 38, 199-203.

(119) Kovács, T.; Ötvös, L. Tetrahedron Lett. 1988, 29, 4525-4528. 
(120) Wen, Z.; Suzol, S. H.; Peng, J.; Liang, Y.; Snoeck, R.; Andrei, G.; Liekens, S.; Wnuk, S. F. Arch Pharm 2017, 350, 1700023-n/a.

(121) Robins, M. J.; Barr, P. J. J. Org. Chem. 1983, 48, 1854-1862.

(122) Liang, Y.; Gloudeman, J.; Wnuk, S. F. J. Org. Chem. 2014, 79, 4094-4103.

(123) Liu, Y.; Prasad, R.; Beard, W. A.; Hou, E. W.; Horton, J. K.; McMurray, C. T.; Wilson, S. H. J. Biol. Chem. 2009, 284, 28352-28366.

(124) Xu, M.; Lai, Y.; Torner, J.; Zhang, Y.; Zhang, Z.; Liu, Y. Nucleic Acids Res 2014, 42, 3675-3691. 


\section{VITA}

SK MD SAZZAD HOSSAIN

EDUCATION

Born, Narail, Bangladesh

$2001-2006$

B.Sc., Chemistry

University of Dhaka, Dhaka, Bangladesh

$2006-2008$

M.Sc., Organic Chemistry

University of Dhaka, Dhaka, Bangladesh

$2012-2017$

Doctoral Candidate

Florida International University, Miami, Florida, USA

April 2017

SoFLACS Graduate Travel Award

\section{PUBLICATIONS AND PRESENTATIONS}

Zhiwei Wen, Sazzad H. Suzol, Jufang Peng, Yong Liang, Robert Snoeck, Graciela Andrei, Sandra Liekens, Stanislaw F. Wnuk; Antiviral and Cytostatic Evaluation of 5-(1-Halo-2Sulfonylvinyl) and 5-(2-Furyl) Uracil Nucleosides. Arch. Pharm. Chem. Life Sci. 2017, 350, e1700023.

Yong Liang, Sazzad H. Suzol, Zhiwei Wen, Alain G. Artiles, Logesh Mathivathanan, Raphael G. Raptis, and Stanislaw F. Wnuk; Uracil Nucleosides with Reactive Group at C5 Position: 5-(1-Halo-2-sulfonylvinyl)uridine Analogues. Org. Lett. 2016, 18, 1418-1421.

Sazzad H. Suzol, A. H. Howlader, and Stanislaw F. Wnuk;

Pyrimidine Nucleosides with Reactive $\beta$-keto sulfonyl Group at C5 Position. In preparation for submission to $J O C$.

Sazzad H. Suzol, A. H. Howlader, and Stanislaw F. Wnuk;

Pyrimidine Nucleosides with Reactive $\beta$-keto sulfonyl Group at C5 Position. 253rd

ACS National Meeting \& Exposition, San Francisco, CA, United States, 2017, April 2-6.

Yong Liang, Sazzad H. Suzol, Zhiwei Wen, and Stanislaw F. Wnuk; 5-[1-Halo-2(arylsulfonyl)vinyl]uracil nucleosides: New probes for cross-linking with amino acids. 251st ACS National Meeting \& Exposition, San Diego, CA, United States, 2016, March 13-17. 